\title{
The global lightning-induced nitrogen oxides source
}

\author{
U. Schumann and H. Huntrieser \\ Deutsches Zentrum für Luft- und Raumfahrt, Institut für Physik der Atmosphäre, Oberpfaffenhofen, 82230 Wessling, \\ Germany
}

Received: 16 January 2007 - Published in Atmos. Chem. Phys. Discuss.: 22 February 2007

Revised: 24 May 2007 - Accepted: 9 July 2007 - Published: 24 July 2007

\begin{abstract}
The knowledge of the lightning-induced nitrogen oxides $\left(\mathrm{LNO}_{\mathrm{x}}\right)$ source is important for understanding and predicting the nitrogen oxides and ozone distributions in the troposphere and their trends, the oxidising capacity of the atmosphere, and the lifetime of trace gases destroyed by reactions with $\mathrm{OH}$. This knowledge is further required for the assessment of other important $\mathrm{NO}_{\mathrm{x}}$ sources, in particular from aviation emissions, the stratosphere, and from surface sources, and for understanding the possible feedback between climate changes and lightning. This paper reviews more than 3 decades of research. The review includes laboratory studies as well as surface, airborne and satellite-based observations of lightning and of $\mathrm{NO}_{\mathrm{x}}$ and related species in the atmosphere. Relevant data available from measurements in regions with strong $\mathrm{LNO}_{\mathrm{x}}$ influence are identified, including recent observations at midlatitudes and over tropical continents where most lightning occurs. Various methods to model $\mathrm{LNO}_{\mathrm{x}}$ at cloud scales or globally are described. Previous estimates are re-evaluated using the global annual mean flash frequency of $44 \pm 5 \mathrm{~s}^{-1}$ reported from OTD satellite data. From the review, mainly of airborne measurements near thunderstorms and cloud-resolving models, we conclude that a "typical" thunderstorm flash produces $15(2-40) \times 10^{25} \mathrm{NO}$ molecules per flash, equivalent to $250 \mathrm{~mol} \mathrm{NO}_{\mathrm{x}}$ or $3.5 \mathrm{~kg}$ of $\mathrm{N}$ mass per flash with uncertainty factor from 0.13 to 2.7 . Mainly as a result of global model studies for various $\mathrm{LNO}_{\mathrm{x}}$ parameterisations tested with related observations, the best estimate of the annual global $\mathrm{LNO}_{\mathrm{x}}$ nitrogen mass source and its uncertainty range is $(5 \pm 3) \mathrm{Tg} \mathrm{a}^{-1}$ in this study. In spite of a smaller global flash rate, the best estimate is essentially the same as in some earlier reviews, implying larger flash-specific $\mathrm{NO}_{\mathrm{x}}$ emissions. The paper estimates the $\mathrm{LNO}_{\mathrm{x}}$ accuracy required for various applications and lays out strategies for improving estimates in the future. An accuracy of
\end{abstract}

Correspondence to: U. Schumann

(ulrich.schumann@dlr.de) about $1 \mathrm{Tg} \mathrm{a}^{-1}$ or $20 \%$, as necessary in particular for understanding tropical tropospheric chemistry, is still a challenging goal.

\section{Introduction}

Thunderstorm lightning has been considered a major source of nitrogen oxides $\left(\mathrm{NO}_{\mathrm{x}}\right.$, i.e. $\mathrm{NO}$ (nitric oxide) and $\mathrm{NO}_{2}$ (nitrogen dioxide)) since von Liebig (1827) proposed it as a natural mechanism for the fixation of atmospheric nitrogen (Hutchinson, 1954). Lightning-induced nitrogen oxides $\left(\mathrm{LNO}_{\mathrm{x}}\right)$ have several important implications for atmospheric chemistry and climate (WMO, 1999; IPCC, 2001). The global $\mathrm{LNO}_{\mathrm{x}}$ source is one of the largest natural sources of $\mathrm{NO}_{\mathrm{x}}$ in the atmosphere (Galloway et al., 2004) and certainly the largest source of $\mathrm{NO}_{\mathrm{x}}$ in the upper troposphere, in particular in the tropics (WMO, 1999).

The $\mathrm{LNO}_{\mathrm{x}}$ source rate is considered to be the least known one within the total atmospheric $\mathrm{NO}_{\mathrm{x}}$ budget (Lawrence et al., 1995; Lee et al., 1997). The global $\mathrm{LNO}_{\mathrm{x}}$ amount cannot be measured directly, and is difficult to determine. Modelling of the horizontal and vertical distribution of lightning and the $\mathrm{LNO}_{\mathrm{x}}$ source is highly uncertain (Price and Rind, 1992; Pickering et al., 1998). Previous reviews of $\mathrm{LNO}_{\mathrm{x}}$ discuss theoretical, laboratory, and field studies to determine the amount of $\mathrm{LNO}_{\mathrm{x}}$ (Tuck, 1976; Drapcho et al., 1983; Borucki and Chameides, 1984; Biazar and McNider, 1995; Lawrence et al., 1995; Levy II et al., 1996; Lee et al., 1997; Price et al., 1997b; Huntrieser et al., 1998; Bradshaw et al., 2000; Ridley et al., 2005), mainly by extrapolating measurements of emissions from individual lightning or thunderstorm events to the global scale (Chameides et al., 1977, 1987). Only a few papers review the determination of the global $\mathrm{LNO}_{\mathrm{x}}$ source by fitting models to observations (Levy II et al., 1996; Zhang et al., 2003b). The majority of studies since the mid1990s, as reviewed in this paper, assumed a best-estimate

Published by Copernicus Publications on behalf of the European Geosciences Union. 


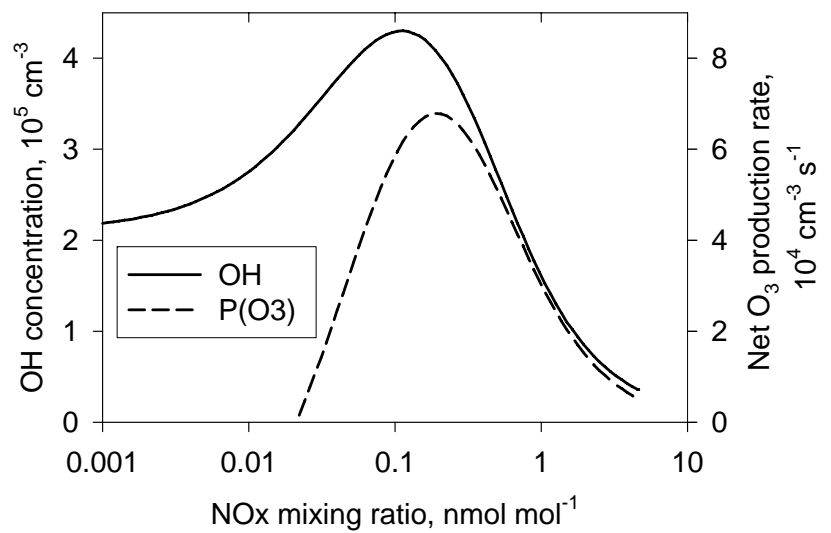

Fig. 1. Dependence of the $\mathrm{OH}$ concentration and the net $\mathrm{O}_{3}$ production rate on the $\mathrm{NO}_{\mathrm{x}}$ mixing ratio calculated with a steady state box model for diurnal average in June at $10 \mathrm{~km}$ altitude and $45^{\circ}$ latitude; background mixing ratios of $\mathrm{O}_{3}: 100 \mathrm{nmol} \mathrm{mol}^{-1} ; \mathrm{H}_{2} \mathrm{O}$ : $47 \mu \mathrm{mol} \mathrm{mol}^{-1}$; $\mathrm{CO}: 120 \mathrm{nmol} \mathrm{mol}^{-1}$; $\mathrm{CH}_{4}: 1660 \mathrm{nmol} \mathrm{mol}^{-1}$; replotted from Ehhalt and Rohrer (1994) with kind permission of Woodhead Publishing Limited.

value of about $5 \mathrm{Tg} \mathrm{a}^{-1}\left(\mathrm{NO}_{\mathrm{x}}\right.$ source values are given in nitrogen mass units per year in this paper), with an uncertainty range $1-20 \mathrm{Tg} \mathrm{a}^{-1}$. Extreme estimates of the $\mathrm{LNO}_{\mathrm{x}}$ source rate such as $0.2 \mathrm{Tg} \mathrm{a}^{-1}$ (Cook et al., 2000) and $220 \mathrm{Tg} \mathrm{a}^{-1}$ (Franzblau and Popp, 1989; Liaw et al., 1990), implying the global $\mathrm{LNO}_{\mathrm{x}}$ contribution from minor to overwhelming, are now considered inconsistent with measured atmospheric $\mathrm{NO}_{\mathrm{x}}$ concentrations and nitrate deposition values (Gallardo and Rodhe, 1997).

Considerable progress has been made recently which allows reducing the uncertainty of the global $\mathrm{LNO}_{\mathrm{x}}$ value. This includes satellite observations of global lightning (Christian et al., 2003), satellite observations of $\mathrm{NO}_{2}$ column distributions (Burrows et al., 1999), airborne in-situ measurements of $\mathrm{NO}_{\mathrm{x}}$ abundance near thunderstorms at midlatitudes (Dye et al., 2000; Huntrieser et al., 2002; Ridley et al., 2004) and over tropical continents, where most lightning occurs (see Sect. 2.4), detailed cloud-resolving model studies (DeCaria et al., 2000; Fehr et al., 2004), and improved global models (Dentener et al., 2006; van Noije et al., 2006).

This paper reviews the present knowledge on the global $\mathrm{LNO}_{\mathrm{x}}$ source rate. It describes the importance of $\mathrm{NO}_{\mathrm{x}}$ for tropospheric chemistry (Sect. 2.1). It reviews knowledge on the $\mathrm{NO}_{\mathrm{x}}$ concentrations, sources and sinks (Sect. 2.2), the essential lightning properties (Sect. 2.3), and the formation of $\mathrm{NO}_{\mathrm{x}}$ from lightning and its detection in the atmosphere (Sect. 2.4). It briefly summarises knowledge on the formation of other trace gases by lightning (Sect. 2.5). It describes the importance of $\mathrm{LNO}_{\mathrm{x}}$ for tropospheric chemistry and its impact on ozone (Sect. 2.6). Moreover, it assesses the global modelling of $\mathrm{NO}_{\mathrm{x}}$ and $\mathrm{LNO}_{\mathrm{x}}$ distributions (Sect. 2.7), the possible climate impact of $\mathrm{LNO}_{\mathrm{x}}(2.8)$, the relative importance of aviation $\mathrm{NO}_{\mathrm{x}}$ for uncertain $\mathrm{LNO}_{\mathrm{x}}$ contributions (Sect. 2.9), and derives requirements on $\mathrm{LNO}_{\mathrm{x}}$ accuracy (Sect. 2.10). Thereafter, the paper reviews the various methods to constrain the $\mathrm{LNO}_{\mathrm{x}}$ source values (Sect. 3). It reevaluates results from flash (Sect. 3.1) and storm (Sect. 3.2) extrapolations using the most recent satellite observations of the global lightning frequency. In addition, the paper reviews for the first time the results of a large number of global model studies discussing $\mathrm{LNO}_{\mathrm{x}}$ impact on tropospheric chemistry (Sect. 3.3). Section 3.3 also elaborates on the potential of better constraining the $\mathrm{LNO}_{\mathrm{x}}$ source estimate using global model fits to observations of concentrations and deposition fluxes of nitrogen compounds and other species. Finally, Sect. 4 presents the conclusions.

\section{Review of $\mathrm{LNO}_{\mathrm{x}}$ contributions and their importance}

\subsection{Importance of $\mathrm{NO}_{\mathrm{x}}$ for atmospheric chemistry}

Nitrogen oxides are critical components of the troposphere which directly affect the abundance of ozone $\left(\mathrm{O}_{3}\right)$ (Crutzen, 1974) and the hydroxyl radical (OH) (Levy II, 1971; Rohrer and Berresheim, 2006). Ozone is known as a strong oxidant, a strong absorber of ultraviolet radiation, and a greenhouse gas (WMO, 1999). Ozone is formed and destroyed by photochemistry and the net production rate depends nonlinearly on the abundance of $\mathrm{NO}_{\mathrm{x}}$ present (Liu, 1977), see Fig. 1. In regions with low $\mathrm{NO}_{\mathrm{x}}$ level (e.g. in the tropical marine boundary layer), the net effect is an $\mathrm{O}_{3}$ destruction. In regions with $\mathrm{NO}_{\mathrm{x}}$ concentrations above a critical level (but not very high), e.g. in the upper troposphere, $\mathrm{O}_{3}$ production dominates. The critical $\mathrm{NO}_{\mathrm{x}}$ level depends on the $\mathrm{O}_{3}$ mixing ratio and may be as low as $5 \mathrm{pmol} \mathrm{mol}^{-1}$ in the oceanic boundary layer with typically low ozone values (Crutzen, 1979), 10$50 \mathrm{pmol} \mathrm{mol}^{-1}$ in the free troposphere (Fishman et al., 1979; Ehhalt and Rohrer, 1994; Brasseur et al., 1996; Davis et al., 1996; Kondo et al., 2003b), and increases with the ambient $\mathrm{O}_{3}$ concentration (Grooß et al., 1998). Hence, in regions remote from strong local pollution, $\mathrm{O}_{3}$ production increases with $\mathrm{NO}_{\mathrm{x}}$ concentration (is " $\mathrm{NO}_{\mathrm{x}}$ limited"). The relative increase of $\mathrm{O}_{3}$ production is largest for low $\mathrm{NO}_{\mathrm{x}}$ concentrations.

The concentrations of $\mathrm{HO}_{\mathrm{x}}$ including $\mathrm{OH}$, the hydroperoxyl radical $\mathrm{HO}_{2}$ and other peroxy radicals, depend also nonlinearly on the $\mathrm{NO}_{\mathrm{x}}$ abundance (Logan et al., 1981; Ehhalt and Rohrer, 1994; Jaeglé et al., 1999; Olson et al., 2006), see again Fig. 1. Under clean air conditions, $\mathrm{OH}$ is mainly produced by $\mathrm{O}_{3}$ photolysis and reactions of the resultant atomic oxygen with water vapour. Under more polluted conditions in the troposphere, $\mathrm{OH}$ is also formed by photolysis of $\mathrm{NO}_{2}$ during the oxidation of carbon monoxide $(\mathrm{CO})$, methane $\left(\mathrm{CH}_{4}\right)$ and non-methane hydrocarbons (NMHC). In highly polluted regions (in " $\mathrm{NO}_{\mathrm{x}}$-saturated" regions) an increase of $\mathrm{NO}_{\mathrm{x}}$, by reactions with $\mathrm{HO}_{2}$ and $\mathrm{NO}_{2}$, reduces the 
Table 1. Best estimate of $\mathrm{LNO}_{\mathrm{x}}$ and total $\mathrm{NO}_{\mathrm{x}}$ emissions in reviews and assessments.

\begin{tabular}{|c|c|c|c|}
\hline Reference & $\begin{array}{l}\text { Best estimate of } \mathrm{LNO}_{\mathrm{x}} \text { source rate (and range) } \\
\text { in nitrogen mass, in } \mathrm{Tg} \mathrm{a}^{-1}\end{array}$ & $\begin{array}{l}\text { Total } \mathrm{NO}_{\mathrm{x}} \text { emissions in ni- } \\
\text { trogen mass, in } \mathrm{Tg} \mathrm{a}^{-1}\end{array}$ & for year \\
\hline Tuck (1976) & 4 & - & \\
\hline Chameides et al. (1977) & $30-40$ & - & \\
\hline Dawson (1980) & 3 & - & \\
\hline Ehhalt and Drummond (1982) & $5(2-8)$ & $39(19-59)$ & 1975 \\
\hline Logan (1983) & $8(2-20)$ & $50 \pm 25$ & 1980 \\
\hline Borucki and Chameides (1984) & $2.6(0.8-8)$ & - & \\
\hline IPCC (1992) & $2-20$ & $35-79$ & \\
\hline Lawrence et al. (1995) & $2(1-8)$ & 60 & \\
\hline Levy et al. (1996) & $4(2-6)$ & - & \\
\hline Price et al. $(1997 \mathrm{a}, \mathrm{b})$ & $12-13(5-25)$ & - & \\
\hline Lee et al. (1997) & $5(2-20)$ & $44(23-81)$ & 1980 \\
\hline Huntrieser et al. (1998) & $4(0.3-22)$ & - & \\
\hline WMO (1999) & $5(2-20)$ & $44(30-73)$ & $1990 \mathrm{~s}$ \\
\hline Ehhalt (1999) & $7(4-10)$ & $45 \pm 7$ & 1990 \\
\hline Holland et al. (1999a) & $13(10-15)$ & $36.1(23-81)$ & $1980 \mathrm{~s}$ \\
\hline Bradshaw et al. (2000) & $6.5(2-10)$ & $45.2(27-86)$ & 1985 \\
\hline IPCC (2001) & $5(2-13)$ & $52(>44)$ & 2000 \\
\hline Leue et al. (2001) & - & $43 \pm 20$ & 1997 \\
\hline Tie et al. (2002) & $3.5-7$ & - & \\
\hline Huntrieser et al. (2002) & $3(1-20)$ & - & \\
\hline Martin et al. (2003) & - & 44.4 & 1997 \\
\hline Galloway et al. (2004) & 5.4 & $\begin{array}{l}13.1 \\
46, \\
82\end{array}$ & $\begin{array}{l}1860, \\
1990 \mathrm{~s}, \\
2050\end{array}$ \\
\hline Müller and Stavrakou (2005) & $2.8(1.6-3.2)$ & $42.1(38.8-43.1)$ & 1997 \\
\hline Boersma et al. (2005) & $3.5(1.1-6.4)$ & - & \\
\hline Law et al. (2006) & $2-9$ & - & \\
\hline Present estimate & $5 \pm 3(2-8)$ & - & \\
\hline
\end{tabular}

$\mathrm{HO}_{2} / \mathrm{OH}$ ratio, and the production rate of $\mathrm{O}_{3}$ (Jaeglé et al., 1999, 2001). OH is the key agent in the atmosphere's oxidising capacity, i.e. the global abundance of tropospheric $\mathrm{O}_{3}$, $\mathrm{OH}$, and hydrogen peroxide $\left(\mathrm{H}_{2} \mathrm{O}_{2}\right)$ (Crutzen, 1979; Logan et al., 1981; Isaksen, 1988; Thompson, 1992; Lelieveld et al., 2004). OH influences the lifetime of a large number of anthropogenic and natural compounds. Here, lifetime is the ratio between the amount of the species and its sinks. Examples are $\mathrm{CO}$ (Logan et al., 1981), sulphur dioxide $\left(\mathrm{SO}_{2}\right)$ (Chatfield and Crutzen, 1984), $\mathrm{CH}_{4}$ (Lelieveld et al., 1998; Bousquet et al., 2006), and further $\mathrm{O}_{3}$ and aerosol precursors or gases relevant to climate that get oxidised by reactions with $\mathrm{OH}$. As a consequence, $\mathrm{NO}_{\mathrm{x}}$ increases not only cause a positive radiative forcing implying warming via $\mathrm{O}_{3}$ (Lacis et al., 1990) but also a cooling via $\mathrm{CH}_{4}$; the forcing from these effects is of similar magnitude globally but differs regionally (Fuglestvedt et al., 1999).

\section{$2.2 \mathrm{NO}_{\mathrm{x}}$ sources, sinks, and concentrations}

The concentration of $\mathrm{NO}_{\mathrm{x}}$ in the atmosphere depends on the source strength and the rates of reactions converting $\mathrm{NO}_{\mathrm{x}}$ to nitric acid $\left(\mathrm{HNO}_{3}\right)$ and particulate nitrate $\left(\mathrm{NO}_{3}^{-}\right)$ and their uptake into precipitation or deposition at the Earth surface (Crutzen, 1979; Warneck, 1988; Dentener and Crutzen, 1993; Ehhalt, 1999). $\mathrm{NO}$ and $\mathrm{NO}_{2}$ are together referred to as $\mathrm{NO}_{\mathrm{x}}$ because $\mathrm{NO}$ reacts in the atmosphere quickly with $\mathrm{O}_{3}$ to form $\mathrm{NO}_{2}$ and equilibrium with respect to photodissociation of $\mathrm{NO}_{2}$ is reached after a few minutes, while the sum of both species remains essentially unchanged (Bradshaw et al., 1999). Collectively, all reactive odd nitrogen or fixed nitrogen is denoted as $\mathrm{NO}_{\mathrm{y}}$, which is any $\mathrm{N}-\mathrm{O}$ combination except the very stable $\mathrm{N}_{2} \mathrm{O}$, i.e. $\mathrm{NO}+\mathrm{NO}_{2}+\mathrm{NO}_{3}+2 \mathrm{~N}_{2} \mathrm{O}_{5}+\mathrm{HNO}_{3}+\mathrm{HNO}_{2}+\mathrm{HNO}_{4}+\mathrm{PAN}+$ $\mathrm{RONO}_{2}+\mathrm{NO}_{3}^{-}$, including PAN (peroxyacetylnitrate, $\left.\mathrm{RC}(\mathrm{O}) \mathrm{OONO}_{2}\right)$ and alkyl nitrates $\left(\mathrm{RONO}_{2}\right)$ (Singh et al., 2007). Conversion of unreactive $\mathrm{N}_{2}$ to more reactive nitrogen $\mathrm{NO}_{\mathrm{y}}$ occurs in the biosphere and the atmosphere (Galloway et al., 2004). 
Table 2. Annual global $\mathrm{NO}_{\mathrm{x}}$ emissions, in the tropics, and at midlatitudes (in $\mathrm{Tg} \mathrm{a}^{-1}$ ).

\begin{tabular}{llllllllll}
\hline Latitude range & $\begin{array}{l}\text { Biomass } \\
\text { burning }\end{array}$ & $\begin{array}{l}\text { Fossil fuel } \\
\text { burning }\end{array}$ & $\begin{array}{l}\text { Soil } \\
\text { release }\end{array}$ & $\begin{array}{l}\mathrm{N}_{2} \mathrm{O} \\
\text { degradation }\end{array}$ & Aviation & $\begin{array}{l}\text { Lightning } \\
\mathrm{NO}_{\mathrm{x}}\end{array}$ & $\begin{array}{l}\text { Sum* } \\
\text { fightning } \\
\text { fraction, } \%\end{array}$ & Reference \\
\hline $90^{\circ} \mathrm{S}-90^{\circ} \mathrm{N}$ & 10.0 & 28.5 & 5.5 & 0.4 & 0.7 & 5.0 & 49.4 & 10 & See footnote*** \\
$35^{\circ} \mathrm{N}-60^{\circ} \mathrm{N}$ & 0.7 & 13.7 & 1.5 & 0 & 0.4 & & 14.1 & 4 & $* * *$ \\
$35^{\circ} \mathrm{S}-35^{\circ} \mathrm{N}$ & 9.2 & 13.6 & 3.9 & 0.4 & 0.3 & 4.3 & 31.3 & 14 & $* * *$ \\
$35^{\circ} \mathrm{S}-35^{\circ} \mathrm{N}$ & 8.3 & 7.8 & 5.4 & - & - & 6.3 & 27.9 & 23 & Bond et al. (2002) $)^{* *}$ \\
$0^{\circ}-24^{\circ} \mathrm{S}$ & 4.4 & 1.2 & 1.5 & 0 & 0.03 & 1.7 & 8.8 & 19 & $* * *$ \\
\hline
\end{tabular}

*All emission rates in nitrogen mass per year $\left(\mathrm{Tg} \mathrm{a}^{-1}\right)$.

**Bond et al. (2002): Fossil fuel ("anthropogenic activity"), biomass burning and soil emissions from EDGAR 2.0, year 1990 (Olivier et al., 1998), lightning $\mathrm{NO}_{\mathrm{x}}$ computed from LIS flash data over the period of $1998-2000$ assuming production values of $6.7 \times 10^{26}$ and $6.7 \times 10^{25}$ NO molecules for each CG and IC flash, respectively.

*** Biomass burning (including waste and biofuel burning); and fossil fuel burning (including industrial emissions but without the AERO2K aviation part) derived from the EDGAR 3.2 Fast Track 2000 dataset (Olivier et al., 2005); Soil release from the Global Emissions Inventory Activity (GEIA; $5.4 \mathrm{Tg} \mathrm{a}^{-1}$ ) (Benkovitz et al., 1996); aviation sources for 2002 from the AERO2K data set (Eyers et al., 2005); stratospheric source from $\mathrm{N}_{2} \mathrm{O}$ degradation for an assumed $0.4 \mathrm{Tg} \mathrm{a}^{-1}$ total (Martin et al., 2006) and downward transport according to stratospheretroposphere exchange mainly near the subtropical jet (Grewe and Dameris, 1996; Stohl et al., 2003). Lightning $\mathrm{NO}_{\mathrm{x}}$ computed from the five-year (April 1995-March 2000) OTD 2.5 Degree Low Resolution Diurnal Climatology data, assuming constant $\mathrm{NO}_{\mathrm{x}}$ production per flash and a total $\mathrm{LNO}_{\mathrm{x}}$ source of $5 \mathrm{Tg} \mathrm{a}^{-1}$.

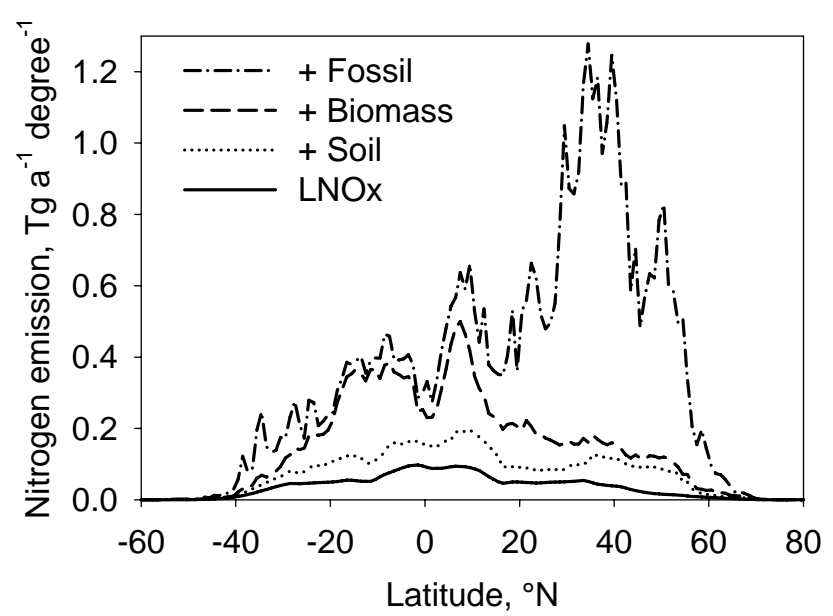

Fig. 2. Atmospheric annual nitrogen mass emission rate per $1^{\circ}$ latitude versus latitude for the year 2000. Lightning emissions are tentatively computed from satellite (OTD)-derived flash frequencies (Christian et al., 2003) (see Fig. 10), assuming constant emissions per flash and $5 \mathrm{Tg} \mathrm{a}^{-1}$ global $\mathrm{LNO}_{\mathrm{x}}$ emissions. Added to this: soil emissions derived from Yienger and Levy (1995) with data taken from the Global Emissions Inventory Activity (GEIA; $5.4 \mathrm{Tg} \mathrm{a}^{-1}$ ) (Granier et al., 2004); biomass burning (including waste and biofuel burning; $10 \mathrm{Tg} \mathrm{a}^{-1}$ ); and fossil fuel burning (including industrial emissions; $28.5 \mathrm{Tg} \mathrm{a}^{-1}$ ) derived from the Emission Database for Global Atmospheric Research (EDGAR) (Olivier et al., 2005).

In the atmosphere, the present sources of global $\mathrm{NO}_{\mathrm{x}}$ (total about $50 \mathrm{Tg} \mathrm{a}^{-1}$ ), see Table 1 , are dominated by anthropogenic sources from fossil fuel combustion (about 28-32) (IPCC, 2001), biomass burning (4-24), soil (4-16) (Lee et al., 1997), nitrous oxide $\left(\mathrm{N}_{2} \mathrm{O}\right)$ degradation in the stratosphere (0.1-1) (Lee et al., 1997; Martin et al., 2006), aircraft (0.7-1) (Schumann et al., 2001; Eyers et al., 2005), and $\mathrm{LNO}_{\mathrm{x}}$. Most of the emissions occur in the Northern Hemisphere, see Table 2 and Fig. 2. Ship $\mathrm{NO}_{\mathrm{x}}$ emissions, presently about 3-6 $\mathrm{Tg} \mathrm{a}^{-1}$ (Eyring et al., 2005; Olivier et al., 2005), are included in the fossil fuel combustion source; they represent an important marine source along the major ship routes. In the preindustrial period, natural sources from soil processes, wildfires (biomass burning), stratospheric sources and $\mathrm{LNO}_{\mathrm{x}}$ dominated the budget: For the year 1860, the total $\mathrm{NO}_{\mathrm{x}}$ emissions are estimated as $13.1 \mathrm{Tg} \mathrm{a}^{-1}$, including 5.4 $\mathrm{Tg} \mathrm{a}^{-1}$ from $\mathrm{LNO}_{\mathrm{x}}$ and $5.1 \mathrm{Tg} \mathrm{a}^{-1}$ from the other natural sources (Galloway et al., 2004).

The principal sink of tropospheric $\mathrm{NO}_{\mathrm{x}}$ is oxidation to nitric acid $\left(\mathrm{HNO}_{3}\right)$ by reaction of $\mathrm{NO}_{2}$ with $\mathrm{OH}$ during the day; during the night, the reaction of $\mathrm{NO}_{2}$ with $\mathrm{O}_{3}$ to form $\mathrm{NO}_{3}$, the oxidation of $\mathrm{NO}_{2}$ by $\mathrm{NO}_{3}$ to form $\mathrm{N}_{2} \mathrm{O}_{5}$, and the subsequent hydrolysis of $\mathrm{N}_{2} \mathrm{O}_{5}$ on aerosols contributes considerably to the nitrogen oxides sinks (Dentener and Crutzen, 1993; van Noije et al., 2006). The oxidation products leave the atmosphere by dry or wet deposition ("acid rain") (Logan, 1983). When deposited they may act as nutrients in terrestrial and marine ecosystems (Holland et al., 1997), and may disturb ecologically sensitive regions such as the Amazon basin, central Africa, south-east Asia (Sanderson et al., 2006), and India (Kulshrestha et al., 2005).

Until the early 1980s very few measurements of nitrogen oxides in the atmosphere were available (Kley et al., 1981; Warneck, 1988; Bradshaw et al., 2000). Whereas $\mathrm{NO}_{2}$ columns can be measured locally from ground (Noxon, 1976), from space in terms of the optical absorption of solar 
Table 3. Airborne air composition measurement experiments in regions with lightning contributions.

\begin{tabular}{|c|c|c|c|c|}
\hline Acronym* & Region & $\begin{array}{l}\text { Altitudes, } \\
\mathrm{km}\end{array}$ & Time Period & References \\
\hline- & $\begin{array}{l}\text { Frankfurt (Germany) to São Paulo (Brazil) } \\
\text { along east coast of Brazil }\end{array}$ & 10.7 & Dec 1982 & Dickerson (1984) \\
\hline GTE/CITE 1A & Central North Pacific around Hawaii & 9 & Nov 1983 & Chameides et al. (1987); Davis et al. (1987) \\
\hline STRATOZ III & $55^{\circ} \mathrm{N}-55^{\circ} \mathrm{S}$, passing over South America & 12 & June 1984 & Drummond et al. (1988) \\
\hline PRE-STORM & Southern Great Plains, Colorado & $0-12$ & June 1985 & Dickerson et al. (1987); Luke et al. (1992) \\
\hline GTE/ ABLE 2A & Amazon Basin, Brazil & $0-5$ & Aug 1985 & $\begin{array}{l}\text { Gregory et al. (1988); Torres et al. (1988); Hoell } \\
\text { (1999) }\end{array}$ \\
\hline GTE/CITE 2 & East N. Pacific and Continental U.S. & 8 & Aug-Sep 1986 & Hübler et al. (1992) \\
\hline STEP & Tropical region near Darwin, Australia & 11 & Jan-Feb 1987 & $\begin{array}{l}\text { Murphy et al. (1993); Pickering et al. (1993); } \\
\text { Russell et al. (1993) }\end{array}$ \\
\hline NDTP & North Dakota, USA & $10.8-12.2$ & 28 June 1989 & Poulida et al. (1996) \\
\hline ELCHEM & New Mexico, USA & $6-12$ & July-Aug 1989 & Ridley et al. $(1994,1996)$ \\
\hline TROPOZ II & $55^{\circ} \mathrm{N}-55^{\circ} \mathrm{S}$, passing South America & $0-11$ & Jan-Feb 1991 & $\begin{array}{l}\text { Rohrer et al. (1997); Jonquieres and Marenco } \\
\text { (1998) }\end{array}$ \\
\hline PEM-West A & West North Pacific $\left(0^{\circ}-45^{\circ} \mathrm{N}\right)$ & $0-12$ & Oct 1991 & $\begin{array}{l}\text { Crawford et al. (1996); Gregory et al. (1996); } \\
\text { Singh et al. (1996) }\end{array}$ \\
\hline GTE/TRACE-A & Brazil and South Atlantic $\left(0^{\circ}-30^{\circ} \mathrm{S}\right)$ & $8-12$ & $\begin{array}{l}\text { Sep-Oct } 1992 \\
\text { (dry season) }\end{array}$ & $\begin{array}{l}\text { Fishman et al. (1996); Pickering et al. (1996); } \\
\text { Smyth et al. (1996a) }\end{array}$ \\
\hline PEM-West B & $30^{\circ} \mathrm{N}-10^{\circ} \mathrm{S}$, West Pacific, Guam - Hong Kong & $8.9-12$ & Feb 1994 & $\begin{array}{l}\text { Gregory et al. (1997); Kawakami et al. (1997); } \\
\text { Singh et al. (1998) }\end{array}$ \\
\hline POLINAT I and II & West Europe and North Atlantic & $0-12$ & $\begin{array}{l}\text { Nov } 1994, \\
\text { June-July } 1995 \text {, } \\
\text { Aug-Nov } 1997\end{array}$ & $\begin{array}{l}\text { Schlager et al. (1997, 1999); Schumann et } \\
\text { al. (2000) }\end{array}$ \\
\hline NOXAR I and II & $\begin{array}{l}\text { Airliner routes between Zurich (Switzerland) } \\
\text { and Atlanta (USA), and Beijing (China) }\end{array}$ & $6-11$ & $1995-1997$ & $\begin{array}{l}\text { Brunner (1998); Jeker et al. (2000); Brunner et } \\
\text { al. (2001) }\end{array}$ \\
\hline SUCCESS & North America & $0-12.5$ & April-May 1996 & Jaeglé et al. (1998) \\
\hline STERAO & North-Eastern Colorado & $2-11$ & June-July 1996 & Stith et al. (1999); Dye et al. (2000) \\
\hline LINOX & Southern Germany and Switzerland & $0-10$ & July 1996 & Huntrieser et al. (1998); Höller et al. (1999) \\
\hline PEM Tropics A & & & Sep 1996 & $\begin{array}{l}\text { Gregory et al. (1999); PEM-Tropics-A-Science- } \\
\text { Team (1999) }\end{array}$ \\
\hline SONEX & USA and North Atlantic & $0-11$ & Oct-Nov 1997 & $\begin{array}{l}\text { Singh et al. (1999); Crawford et al. (2000); } \\
\text { Thompson et al. (2000b) }\end{array}$ \\
\hline EULINOX & Germany and Southern Europe & $1-10$ & July 1998 & $\begin{array}{l}\text { Höller and Schumann (2000); Höller et } \\
\text { al. (2000); Huntrieser et al. (2002) }\end{array}$ \\
\hline MOZAIC & $\begin{array}{l}\text { Airliners routes between mid Europe and South } \\
\text { Africa, South America and Far East }\end{array}$ & $0-12$ & $1998-2005$ & Marenco et al. (1998); Volz-Thomas et al. (2005) \\
\hline STREAM 98 & Canada & $7.5-13$ & July 1998 & Lange et al. (2001) \\
\hline BIBLE & Tropical western Pacific and Australia & $1-14$ & $\begin{array}{l}\text { Sep-Oct } 1998, \\
\text { Aug-Sep } 1999, \\
\text { Nov-Dec } 2000\end{array}$ & Kondo et al. (2003a); Koike et al. (2007) \\
\hline INCA & $55^{\circ} \mathrm{N}-55^{\circ} \mathrm{S}$, passing South America & $0-12$ & $\begin{array}{l}\text { March-April } \\
2000\end{array}$ & Baehr et al. (2003); Schumann et al. (2004a) \\
\hline CONTRACE & West Europe & $0-12$ & $\begin{array}{l}\text { Nov 2001-July } \\
2003\end{array}$ & Huntrieser et al. (2005) \\
\hline SPURT & $35-75^{\circ} \mathrm{N}, 10^{\circ} \mathrm{W}-20^{\circ} \mathrm{E}$ & $0-13.7$ & $\begin{array}{l}\text { Nov 2001-July } \\
2003\end{array}$ & Engel et al. (2006) \\
\hline CRYSTAL-FACE & Florida, USA & $8-18$ & July 2002 & Ridley et al. (2004) \\
\hline HIBISCUS & Brazil, and tropical tropopause region & $10-23$ & $\begin{array}{l}\text { Feb-March } \\
2004\end{array}$ & Pommereau et al. (2007) \\
\hline TROCCINOX 2004 and 2005 & $\begin{array}{l}\text { Between Europe and Brazil, and local flights } \\
\text { near State of Sao Paulo }\end{array}$ & $\begin{array}{l}0-12.5 \text { and } \\
0-20\end{array}$ & $\begin{array}{l}\text { Jan-March } \\
\text { 2004, and } \\
\text { Jan-Feb } 2005\end{array}$ & $\begin{array}{l}\text { Schumann et al. (2004b); } \\
\text { Huntrieser et al. (2007); } \\
\text { http://www.pa.op.dlr.de/troccinox/ }\end{array}$ \\
\hline INTEX-A/ICARTT/ITOP & $\begin{array}{l}\text { North America, North Atlantic and West Eu- } \\
\text { rope }\end{array}$ & $0-12.8$ & July-Aug 2004 & Fehsenfeld et al. (2006); Singh et al. (2006) \\
\hline CARIBIC & $\begin{array}{l}\text { Airliner routes between mid Europe and South } \\
\text { Africa, South America and Far East }\end{array}$ & $0-12$ & 2005 & Brenninkmeijer et al. $(2005,2007)$ \\
\hline SCOUT-O3 & $\begin{array}{l}\text { Between Europe and Darwin, Australia, and lo- } \\
\text { cal flights in the Hector cloud north of Darwin }\end{array}$ & $0-20$ & Nov-Dec 2005 & http://www.ozone-sec.ch.cam.ac.uk/scout_o3 \\
\hline ACTIVE and TWPICE & Area around Darwin, Australia & $0-20$ & $\begin{array}{l}\text { Nov 2005- } \\
\text { March } 2006\end{array}$ & $\begin{array}{l}\text { http://www.atm.ch.cam.ac.uk/active/ } \\
\text { http://www.bom.gov.au/bmrc/wefor/research/ } \\
\text { twpice.htm }\end{array}$ \\
\hline AMMA & $\begin{array}{l}\text { Area around Ouagadougou, Burkina Faso, West } \\
\text { Africa }\end{array}$ & $0-20$ & Aug 2006 & Redelsperger et al. (2006) \\
\hline
\end{tabular}


Table 3. Continued.

*) ACTIVE: Aerosol and Chemical Transport in Tropical Convection; AMMA: African Monsoon Multidisciplinary Analysis; BIBLE: Biomass Burning and Lightning Experiment; CARIBIC: Civil Aircraft for the Regular Investigation of the Atmosphere Based on an Instrumented Container; CONTRACE: Convective Transport of Trace Gases into the Middle and Upper Troposphere over Europe: Budget and Impact on Chemistry; CRYSTAL-FACE: The Cirrus Regional Study of Tropical Anvils and Cirrus Layers - Florida Area Cirrus Experiment; ELCHEM: Electrified Cloud Chemistry; EULINOX: European Lightning Nitrogen Oxides Experiment; GTE/ABLE 2A; Global Tropospheric Experiment/Amazon Boundary Layer Experiment 2A; GTE CITE: Global Tropospheric Experiment - Chemical Instrumentation Test and Evaluation; GTE/TRACE-A: Global Tropospheric Experiment/Transport and Chemistry Near the Equator - Atlantic; HIBISCUS: Impact of tropical convection on the upper troposphere and lower stratosphere at global scale; ICARTT: International Consortium for Atmospheric Research on Transport and Transformation; INCA: Interhemispheric Differences in Cirrus Properties from Anthropogenic Emissions; INTEX-A: Intercontinental Chemical Transport Experiment - North America; ITOP: Intercontinental Transport of Ozone and Precursors; LINOX: Lightning Nitrogen Oxides Experiment; MOZAIC: Measurement of Ozone by Airbus in-service Aircraft; NDTP: North Dakota Thunderstorm Project; NOXAR II: Nitrogen Oxides and Ozone along Air Routes; PEM: Pacific Exploratory Mission; POLINAT: Pollution in the North Atlantic flight corridor; PRE-STORM: Preliminary Regional Experiment for STORM-CENTRAL; SCOUT-O3: StratosphericClimate Links with Emphasis on the Upper Troposphere and Lower Stratosphere; SONEX: Subsonic Assessment, Ozone and Nitrogen Oxide Experiment; SPURT: Spurenstofftransport in der Tropopausenregion; STEP: Stratosphere Troposphere Exchange Project; STERAO: Stratosphere - Troposphere Experiment - Radiation, Aerosols and Ozone; STRATOZ III: Stratospheric Ozone Experiment; STREAM: Stratosphere-Troposphere Experiment by Aircraft Measurements; SUCCESS: Subsonic aircraft: Contrail and cloud effects special study; TROCCINOX: Tropical Convection, Cirrus, and Nitrogen Oxides Experiment; TROPOZ II: Tropospheric Ozone Experiment; TWPICE: Tropical Warm Pool International Cloud Experiment.

Table 4. Nitrogen oxides chemical lifetimes (in days) in various atmospheric regions.

\begin{tabular}{llllll}
\hline Altitude range, $\mathrm{km}$ & Global $^{(1)}$ & North America $^{(2)}$ & Western North Pacific $^{(3)}$ & South Atlantic Basin $^{(4)}$ & Tropical South Pacific $^{(5)}$ \\
\hline $2-4$ & 1 & $0.3-0.8$ & $1.1-1.8$ & 0.18 & $0.7-1$ \\
$4-8$ & 5 & $1-3$ & $1.5-2.4$ & 0.66 & $1.1-2.1$ \\
$8-12$ & 10 & $3-10$ & $3.2-8.9$ & 2.4 & $4.2-7.4$ \\
\hline
\end{tabular}

(1) Tropospheric regions which have not recently experienced deep convection. Based on MATCH-MPIC model results (Lawrence et al., 2003b; von Kuhlmann et al., 2003b). The three altitude ranges given correspond to the lower troposphere, middle troposphere and upper troposphere in the model.

(2) Photochemical model constrained to data obtained during SUCCESS over North America in April and May (Jaeglé et al., 1998).

(3) Western North Pacific, $0-42^{\circ} \mathrm{N}$, photochemical model constrained with observed $\mathrm{NO}, \mathrm{O}_{3}, \mathrm{H}_{2} \mathrm{O}, \mathrm{CO}, \mathrm{NMHC}_{2} \mathrm{H}_{2}, \mathrm{CH}_{4}$, temperature, pressure, and UV solar flux values (PEM West A). In this analysis, the $\mathrm{NO}_{\mathrm{x}}$ lifetime decreases with latitude. The lower/upper bounds given reflect the values for $18-42^{\circ} \mathrm{N}$ and $0-18^{\circ} \mathrm{N}$, respectively (Davis et al., 1996).

(4) South Atlantic Basin. Model for the Southern Hemisphere TRACE-A data (Jacob et al., 1996; Smyth et al., 1996b).

(5) Tropical South Pacific (PEM-Tropics A), photochemical model constrained with observations (Schultz et al., 1999).

light in limb (Russell III et al., 1993; Llewellyn et al., 2004; Rind et al., 2005) and nadir (Burrows et al., 1999; Zhang et al., 2000), tropospheric NO cannot be determined by remote sensing accurately. In recent decades, in-situ instruments to measure $\mathrm{NO}, \mathrm{NO}_{\mathrm{x}}$, and $\mathrm{NO}_{\mathrm{y}}$ and their speciation accurately at low and high concentrations have been developed (Clemitshaw, 2004; Singh et al., 2007). Accurate in-situ measurements of NO are difficult to perform, because of the large range of concentrations and the large spatial and temporal variability. Many in-situ instruments determine the NO concentration from the rate of photon emissions from chemiluminescence (CL) during reaction of $\mathrm{NO}$ with excess $\mathrm{O}_{3}$ in a reaction chamber; $\mathrm{NO}_{\mathrm{y}}$ is measured similarly after catalytic conversion of $\mathrm{NO}_{\mathrm{y}}$ to $\mathrm{NO}$ (Fahey et al., 1985; Hübler et al., 1992; Bradshaw et al., 1998). Alternatively, NO may be measured with low detection limits using two-photon laserinduced fluorescence (TP-LIF) (Sandholm et al., 1990) and $\mathrm{NO}_{2}$ with a time-gated laser-induced fluorescence instrument (LIF) (Thornton et al., 2000).

Since the early 1980s, many airborne field experiments have been carried out to measure $\mathrm{NO}_{\mathrm{x}}$ and $\mathrm{NO}_{\mathrm{y}}$ components in the free troposphere (Bradshaw et al., 2000; Emmons et al., 2000; Brunner et al., 2001), see Table 3. Several experiments obtained measurements of $\mathrm{NO}_{\mathrm{x}}, \mathrm{O}_{3}$, ozone precursors, aerosols and air mass tracers in convective outflow regions. But only a few dedicated experiments (such as STERAO, LINOX, EULINOX, and TROCCINOX) measured these species in the inflow and outflow regions of the storms together with measurements of the cloud structure and kinematics and the lightning activity, which can be used to 
(a)

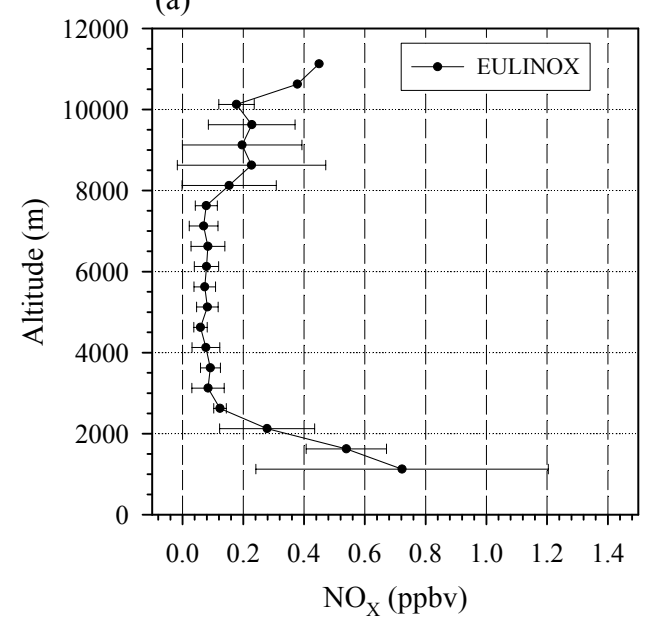

(b)

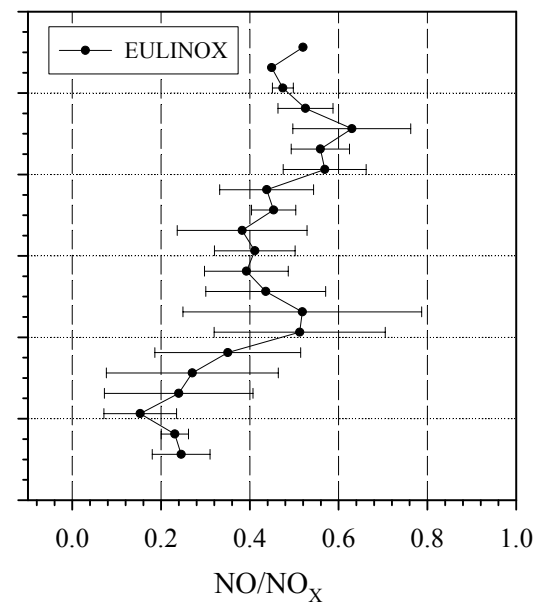

Fig. 3. Average profiles of (a) $\mathrm{NO}_{\mathrm{x}}$ concentration and (b) $\mathrm{NO} / \mathrm{NO}_{\mathrm{x}}$ ratio (Huntrieser et al., 2002). The profiles represent the mean values over all EULINOX mission days (except the case of $21 \mathrm{July,} \mathrm{with} \mathrm{an} \mathrm{exceptionally} \mathrm{strong} \mathrm{thunderstorm).} \mathrm{The} \mathrm{horizontal} \mathrm{bars} \mathrm{indicate} \mathrm{standard}$ deviations.

connect the chemical measurements in the convective outflow to specific cloud and lightning properties.

The atmospheric $\mathrm{NO}_{\mathrm{x}}$ mole fraction or mixing ratio (i.e. number of $\mathrm{NO}_{\mathrm{x}}$ molecules per number of air molecules) spans a wide range $\left(0.001-100 \mathrm{nmol} \mathrm{mol}^{-1}\right)$ and shows considerable small-scale spatial and temporal variability due to local sources and highly variable sinks. The mixing ratio values reach from an order of $1-10 \mathrm{pmol} \mathrm{mol}^{-1}$ in the clean maritime boundary layer to an order of $10-100 \mathrm{nmol} \mathrm{mol}^{-1}$ in polluted continental boundary layers (Fehsenfeld and Liu, 1993; Carroll and Thompson, 1995). It reaches an order of $0.05-1 \mathrm{nmol} \mathrm{mol}^{-1}$ near the tropopause, and about $20 \mathrm{nmol} \mathrm{mol}^{-1}$ near $3 \mathrm{hPa}$ pressure altitude in the tropical stratosphere (Grooß and Russell III, 2005). The tropospheric vertical profile often shows a $\mathrm{C}$-shape with low values in the mid-troposphere and high values in the polluted boundary layer and near the tropopause (Kley et al., 1981; Drummond et al., 1988; Warneck, 1988; Luke et al., 1992; Rohrer et al., 1997; Huntrieser et al., 2002), see for example Fig. 3a. Upper tropospheric $\mathrm{NO}_{\mathrm{x}}$ stems from fast vertical transport from the planetary boundary layer via convection, downward mixing of stratospheric sources, and from in-situ sources from lightning and aviation (Ehhalt et al., 1992; Schlager et al., 1997; Thompson et al., 2000b). The equilibrium ratio of $\mathrm{NO} / \mathrm{NO}_{\mathrm{x}}$ increases with the $\mathrm{NO}_{2}$ photolysis rate, and decreases with the ambient $\mathrm{O}_{3}$ concentration and ambient temperature (Schlager et al., 1997); hence, it varies typically between 0.3 and 0.9 during day time (Fig. 3b), with the largest values above clouds in the upper tropical troposphere, and approaches zero quickly during night.

The lifetime for $\mathrm{NO}_{\mathrm{x}}$ with respect to photochemical loss, see Table 4 and a plot in Levy et al. (1999), varies between 0.2 and 10 days, generally increasing with latitude and alti- tude in the troposphere; the lifetime of $\mathrm{NO}_{2}$ is shorter than that of $\mathrm{NO}$ (Davis et al., 1996). The lifetime of $\mathrm{HNO}_{3}$ against photolysis is of the order of 10 to 20 days in the tropics and increases strongly with latitude (Jacob et al., 1996; Tie et al., 2001). $\mathrm{HNO}_{3}$ rainout occurs intermittently in precipitation events (Giorgi and Chameides, 1985; Giannakopoulos et al., 1999; Shindell et al., 2006). In the troposphere, part of the $\mathrm{NO}_{\mathrm{x}}$ gets converted to PAN which is thermally unstable, not water-soluble, and has a long lifetime in the cold upper troposphere ( 100 days at $-30^{\circ} \mathrm{C}$ ) (Tie et al., 2001). As a consequence, the tropospheric $\mathrm{NO}_{\mathrm{x}} / \mathrm{NO}_{\mathrm{y}}$ ratio varies strongly, typically from 0.05 to 0.5 (Ridley et al., 1994; Singh et al., 1996; Ziereis et al., 2000; Koike et al., 2003; Hegglin et al., 2006). This ratio is often larger than in photochemical equilibrium with $\mathrm{HNO}_{3}$ and PAN, suggesting fresh $\mathrm{NO}_{\mathrm{x}}$ sources from convection and lightning (Jaeglé et al., 1998; Ko et al., 2003; Koike et al., 2003). In the upper troposphere over the North Atlantic, the $\mathrm{NO}_{\mathrm{y}}$ composition was found to be dominated by a mixture of $\mathrm{NO}_{\mathrm{x}}(25 \%), \mathrm{HNO}_{3}(35 \%)$ and PAN $(17 \%)$ (Talbot et al., 1999). Over North America in summer, $\mathrm{NO}_{\mathrm{x}}$ contributes about $15 \%$ to $\mathrm{NO}_{\mathrm{y}}$, while $\mathrm{PAN}$ and $\mathrm{HNO}_{3}$ are the dominant species, providing some $65 \%$ of $\mathrm{NO}_{\mathrm{y}}$, with PAN dominating in the upper troposphere and $\mathrm{HNO}_{3}$ in the lower troposphere (Singh et al., 2007). In the upper troposphere, the $\mathrm{NO}_{\mathrm{x}} / \mathrm{HNO}_{3}$ ratio varies strongly because convection provides local sources of $\mathrm{NO}_{\mathrm{x}}$ while $\mathrm{HNO}_{3}$ is depleted due to scavenging during uplift (Jaeglé et al., 1998). In the tropical Pacific, convection has been observed to increase $\mathrm{NO}_{\mathrm{x}}$ over land and to decrease $\mathrm{NO}_{\mathrm{x}}$ over the ocean because of upward transport of polluted or very clean air masses, respectively (Koike et al., 2003). The $\mathrm{NO}_{\mathrm{x}} / \mathrm{HNO}_{3}$ ratio has been used to test the validity of photochemical models and as "chemical clock" to determine the age of air since outflow from 
Table 5. Satellite platforms and instruments providing $\mathrm{NO}_{2}$ column measurements.

\begin{tabular}{|c|c|c|c|c|c|c|c|c|}
\hline Instrument* & Satellite & Period & $\begin{array}{l}\text { Spatial resolu- } \\
\text { tion, } \\
\mathrm{km}^{2}\end{array}$ & $\begin{array}{l}\text { Local time } \\
\text { at equator }\end{array}$ & Swath, km & $\begin{array}{l}\text { Global cover } \\
\text { after, days }\end{array}$ & $\begin{array}{l}\text { Spectral } \\
\text { range, } \mathrm{nm}\end{array}$ & Reference \\
\hline GOME & ERS-2 & $1995-2003^{* *}$ & $320 \times 40$ & 10:30 a.m. & 960 & 3 & $240-790$ & Burrows et al. (1999) \\
\hline SCIAMACHY & ENVISAT & Since 2002 & $60 \times 30$ & 10:00 a.m. & 960 & 6 & $240-2380$ & Bovensmann et al. (1999) \\
\hline OMI & AURA & Since 2004 & $13 \times 24$ & 01:45 p.m. & 2600 & 1 & $270-500$ & Levelt et al. (2006) \\
\hline GOME-2 & METOP & Since Oct 2006 & $80 \times 40$ & 09:30 a.m. & 1920 & 1.5 & $240-790$ & Munro et al. (2006) \\
\hline
\end{tabular}

*AURA: NASA Earth Science satellite; ENVISAT: European Earth Observation satellite; ERS-2: European Remote Sensing Satellite; GOME (-2): Global Ozone Monitoring Experiment (-2); METOP: ESA - Polar orbiting weather satellite; OMI: Ozone Monitoring Instrument; SCIAMACHY: Scanning Imaging Absorption Spectrometer for Atmospheric Cartography.

${ }^{* *}$ GOME continued measurements with reduced spatial coverage thereafter.

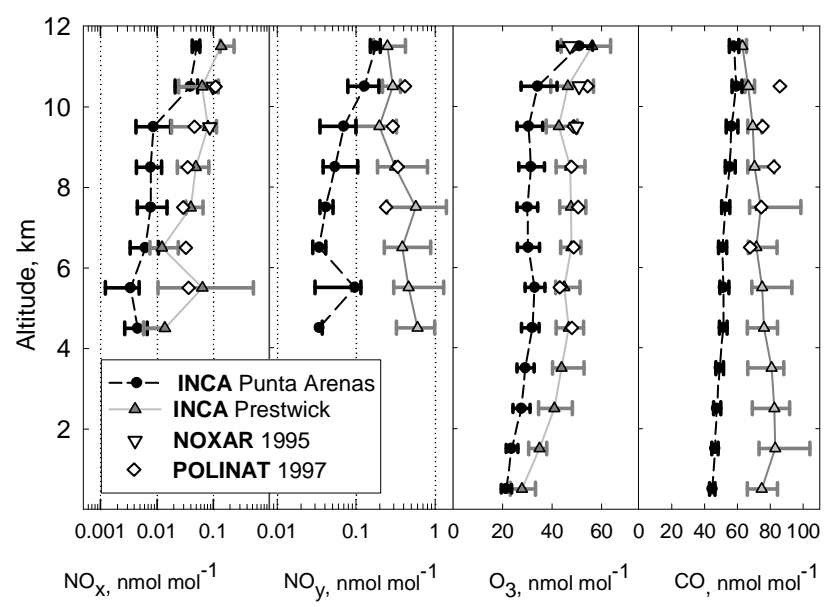

Fig. 4. Trace gas profiles from airborne measurement flights out of Punta Arenas in March 2000 and Prestwick in September 2000 during the project INCA (Baehr et al., 2003). For comparison median values of POLINAT II (Shannon, Ireland, July-September 1997) (Schumann et al., 2000) and NOXAR 1995 (>50 ${ }^{\circ} \mathrm{N}$ ) (Brunner et al., 2001) are included. Symbols and whiskers indicate median values and $25 \%$ and $75 \%$ percentiles, respectively.

convective clouds (Prather and Jacob, 1997; Schultz et al., 1999; Wang et al., 2000; Bertram et al., 2007).

Because of the different magnitudes of the $\mathrm{NO}_{\mathrm{x}}$ emissions, tropospheric concentrations are higher over the continents than over the oceans (Drummond et al., 1988), and higher at northern than at southern midlatitudes (Baehr et al., 2003), see Fig. 4. First climatologies of $\mathrm{NO}_{\mathrm{x}}$ and $\mathrm{NO}_{\mathrm{y}}$ (Carroll and Thompson, 1995; Emmons et al., 1997; Thakur et al., 1999) have been considerably extended by the Nitrogen Oxide and Ozone Concentration Measurements along Air Routes (NOXAR) project. The measurements in the upper troposphere at Northern midlatitudes show background $\mathrm{NO}_{\mathrm{x}}$ values in the $20-200 \mathrm{pmol} \mathrm{mol}^{-1}$ range, highly skewed probability distributions, and large regions with $\mathrm{NO}_{\mathrm{x}}>$ $0.5 \mathrm{nmol} \mathrm{mol}{ }^{-1}$ reflecting fresh sources from upward convection of polluted boundary layer air masses and lightning contributions (Brunner et al., 2001), see Fig. 5.
Measurements of $\mathrm{NO}_{2}$ profiles from space have been obtained by limb sounding methods, e.g., the Halogen Occultation Experiment (HALOE) (Russell III et al., 1993), SAGE II (Stratospheric Aerosol and Gas Experiment II) (McCormick, 1987), the Michelson Interferometer for Passive Atmospheric Sounding (MIPAS) (Funke et al., 2005), and the Optical Spectrograph and Infrared Imager System (OSIRIS) (Llewellyn et al., 2004). These instruments provide profiles versus altitude and latitude in the stratosphere and in the upper troposphere above clouds. $\mathrm{NO}_{2}$ columns above the Earth surface can be derived from nadir measurements. Data on the global distribution of $\mathrm{NO}_{2}$ columns have been provided by the Global Ozone Monitoring Experiment GOME since 1995 (Burrows et al., 1999), and later by SCIAMACHY (Bovensmann et al., 1999), and OMI (Levelt et al., 2006); GOME-2 on METOP was launched recently, see Table 5. The GOME and SCIAMACHY satellite overpasses are restricted to the morning hours (10:00 or 10:30 LT), when the $\mathrm{LNO}_{\mathrm{x}}$ source is small (Kurz and Grewe, 2002). Better spatial coverage and observations during the early afternoon is provided by OMI (Bucsela et al., 2006). Measurements on such low orbiting satellites suffer the effects of cosmic radiation when passing the South Atlantic anomaly of the geomagnetic field off the coast of Southern Brazil (Heirtzler, 2002).

The total $\mathrm{NO}_{2}$ molecule column amounts to about 1.5$3 \times 10^{15} \mathrm{~cm}^{-2}$ in the tropics and $0.5-6 \times 10^{15} \mathrm{~cm}^{-2}$ at middle and high latitudes (Wenig et al., 2004). The stratospheric part is rather smooth longitudinally and dominates in remote oceanic regions with low local pollution. Therefore, the tropospheric part, see Fig. 6, may be obtained by subtracting the total column in such remote regions. The tropospheric $\mathrm{NO}_{2}$ column may reach a maximum of up to $50 \times 10^{15} \mathrm{~cm}^{-2}$ locally at $30 \times 60 \mathrm{~km}^{2}$ resolution over the industrial regions in the annual mean. In the tropics the $\mathrm{NO}_{2}$ plumes originate from the continents, presumably mainly from biomass burning, soil emissions and local pollution near large cities. The tropospheric column of $\mathrm{NO}_{2}$ molecules per unit surface area is dominated by the $\mathrm{NO}_{2}$ abundance in the lower troposphere. The presence of clouds prevents the detection of $\mathrm{NO}_{2}$ below the cloud, and enhances detection of $\mathrm{NO}_{2}$ above cloud top. 

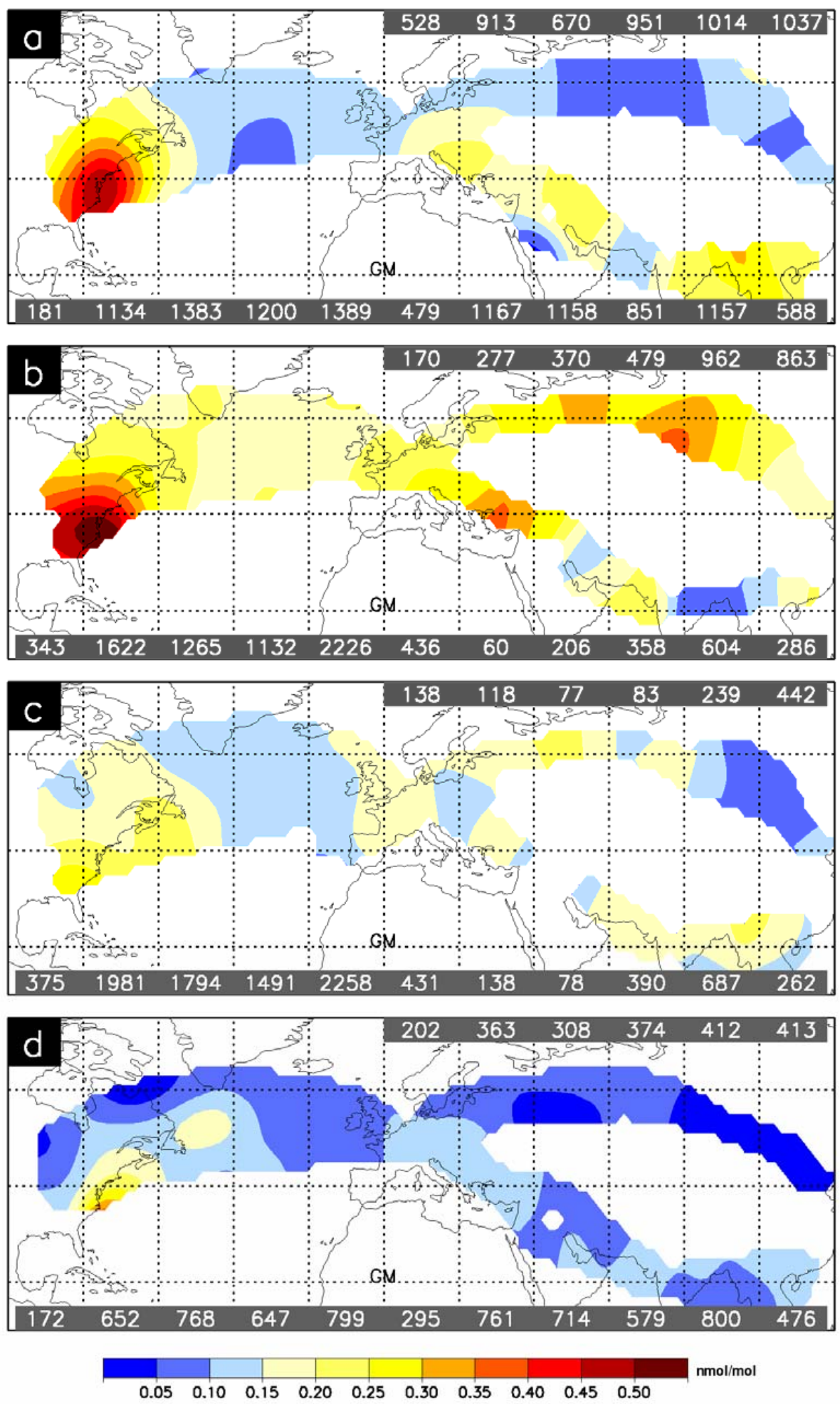

Fig. 5. Distribution of $\mathrm{NO}_{\mathrm{x}}$ mixing ratio in the $330-220 \mathrm{hPa}$ altitude range in the four seasons (a: MAM, b: JJA, c: SON, d: DJF). Numbers denote the sample sizes along the routes (Brunner, 1998).

The satellite-derived $\mathrm{NO}_{2}$ columns have been used together with estimates of the $\mathrm{NO}_{2}$ lifetime or with global mod- els to derive global or regional $\mathrm{NO}_{\mathrm{x}}$ budgets (Leue et al., 2001; Velders et al., 2001; Lauer et al., 2002; Martin et al., 


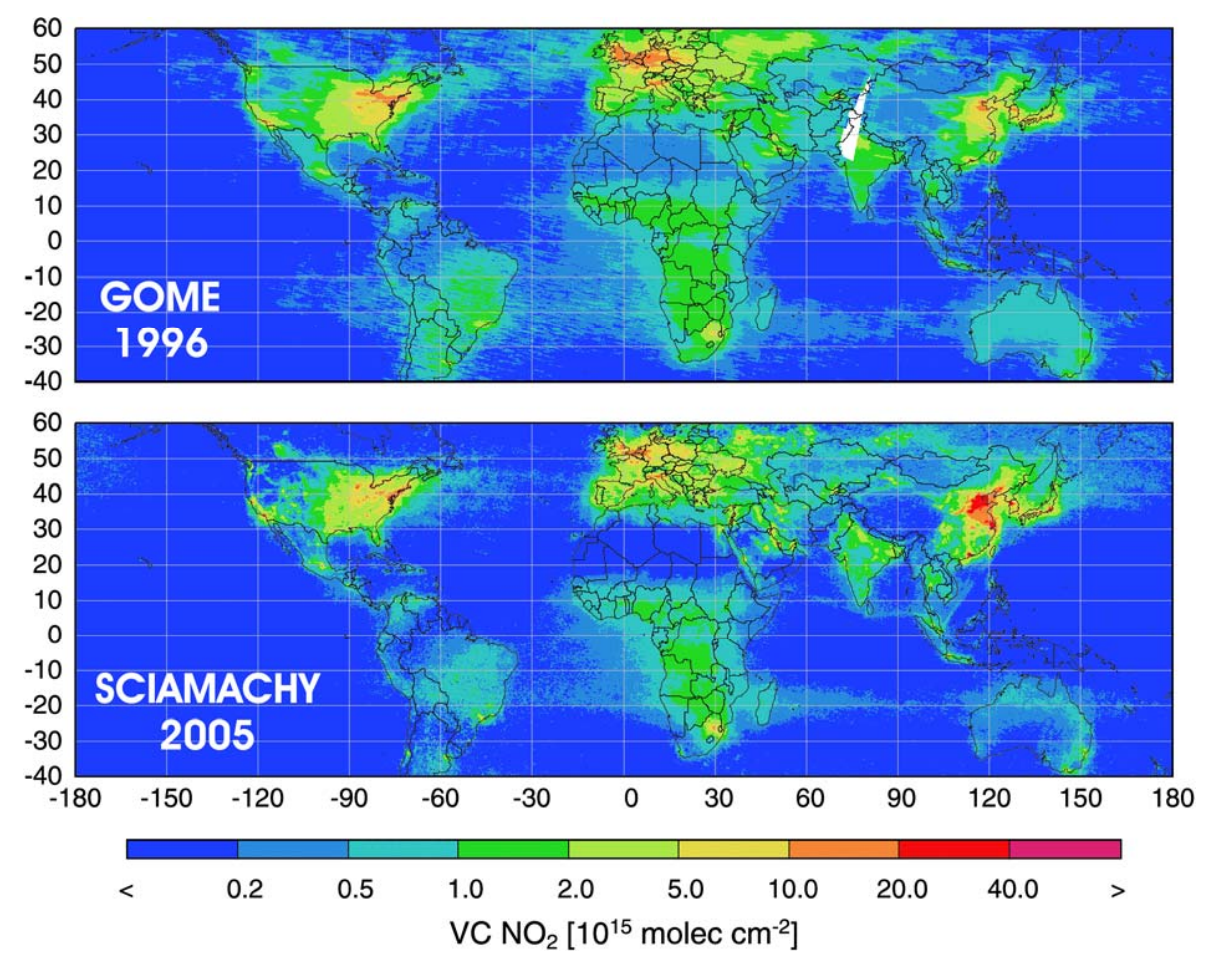

Fig. 6. Annual mean tropospheric $\mathrm{NO}_{2}$ column density versus longitude and latitude from a retrieval of, top: GOME data for the year 1996; bottom: SCIAMACHY data for the year 2005. The data and the analysis method are described in Richter et al. (2005). Figure provided by A. Richter (personal communication, 2006).

2002a; Richter and Burrows, 2002; Duncan et al., 2003; Edwards et al., 2003; Kunhikrishnan et al., 2004; Savage et al., 2004; Choi et al., 2005; Irie et al., 2005; Jaeglé et al., 2005; Konovalov et al., 2005; Meyer-Arnek et al., 2005; Richter et al., 2005; Ma et al., 2006; van der A et al., 2006; van Noije et al., 2006). Figure 6 illustrates the improvement in spatial resolution provided by SCIAMACHY compared to GOME. On the other hand, the GOME time series is still longer. GOME and SCIAMACHY data have been used to detect decreases of $\mathrm{NO}_{2}$ column values over Europe and the USA and increases over China (Richter et al., 2005), which are obvious from Fig. 6. Moreover, GOME and SCIAMACHY data have been used successfully to detect ship- $\mathrm{NO}_{\mathrm{x}}$ emissions, in spite of their small $\mathrm{NO}_{2}$ columns of the order of $(0.5-1) \times 10^{15} \mathrm{~cm}^{-2}$ (Beirle et al., 2004a; Richter et al., 2004).

The $\mathrm{LNO}_{\mathrm{x}}$ contribution to the $\mathrm{NO}_{2}$ column is difficult to observe directly from space for various reasons (Hild et al., 2002; Choi et al., 2003; Beirle et al., 2004b; Martin et al., 2006). Any correlation between $\mathrm{NO}_{2}$ columns and lightning frequency densities is not immediately evident. Different methods of GOME retrievals vary by more than $10 \%$ (van Noije et al., 2006). Therefore, accurate $\mathrm{LNO}_{\mathrm{x}}$ estimates require $\mathrm{LNO}_{\mathrm{x}}$ column contributions significantly larger than $10 \%$. Model studies compute $\mathrm{LNO}_{\mathrm{x}}$ contributions to the $\mathrm{NO}_{2}$ column below (2-6) $\times 10^{14}$ molecules $\mathrm{cm}^{-2}$ (Martin et al., 2003, 2007; Boersma et al., 2005), i.e. a small fraction of the annual mean $\mathrm{NO}_{2}$ column even in the tropics. The computed $\mathrm{LNO}_{\mathrm{x}}$ column contribution is generally below 20\% (Martin et al., 2003; Boersma et al., 2005; van Noije et al., 2006) with localized fractions of more than $80 \%$ in regions with weak surface $\mathrm{NO}_{\mathrm{x}}$ emissions (Martin et al., 2007). Detections of $\mathrm{LNO}_{\mathrm{x}}$ contributions to the $\mathrm{NO}_{2}$ column in space-based observations are discussed in Sect. 2.4.

\subsection{Lightning}

Lightning is a transient, high-current electric discharge over a path length of several kilometres in the atmosphere (Uman, 1987). The majority of lightning in the Earth's atmosphere is associated with convective thunderstorms (MacGorman and Rust, 1998; Rakov and Uman, 2003). Lightning forms from the breakdown of charge separation in thunderstorms. Charge separation is efficient for strong updrafts containing supercooled liquid water, ice crystals and hail or graupel (Takahashi, 1984; Saunders, 1993; Deierling et al., 2005; Petersen et al., 2005; Kuhlman et al., 2006; Sherwood et al., 2006). The charge separation leads to high electric field strengths in thunderstorms (Marshall et al., 1995). Once the electric field exceeds a certain threshold value, a lightning discharge may occur (Stolzenburg et al., 2007). The threshold value decreases with altitude and is of the order of 100 to $400 \mathrm{kV} \mathrm{m}^{-1}$, far smaller than in the laboratory, 

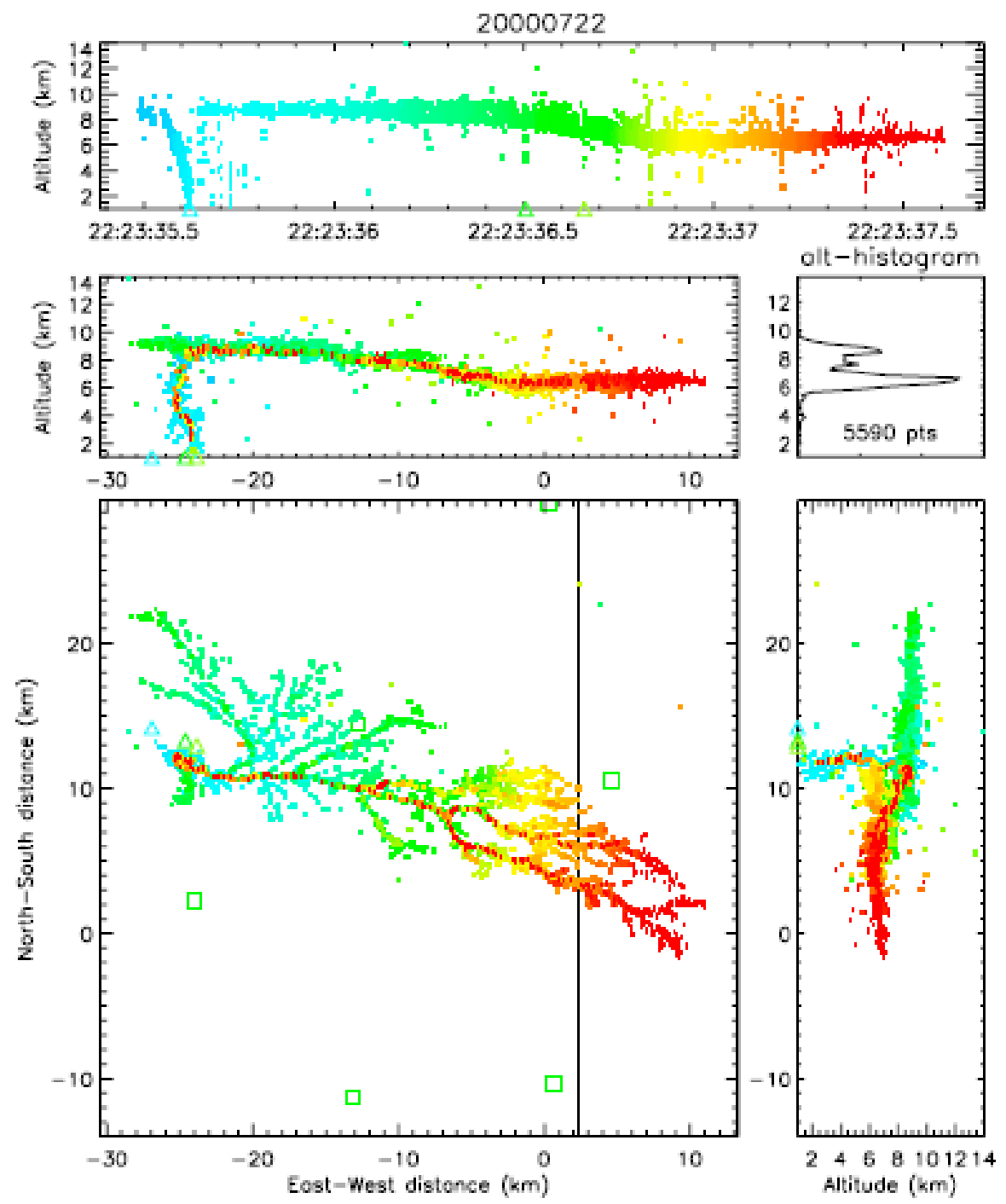

Fig. 7. Radiation sources for a negative CG discharge observed within STEPS. The colours indicate time progression, and the different panels show the evolution of the flash in (top) height-time, (bottom left) plan view, and in (middle left) east-west (E-W) and (bottom right) north-south $(\mathrm{N}-\mathrm{S})$ vertical projections. Also shown is a histogram of the source heights. The triangles indicate negative ground strike times and locations from the National Lightning Detection Network (NLDN). The squares in the plan view indicate the location of measurement stations, and the vertical line denotes the Colorado-Kansas state border; from Thomas et al. (2004).

possibly because of cosmic-ray-induced electrical breakdown in the atmosphere (Dwyer, 2005; Gurevich and Zybin, 2005; Khaerdinov et al., 2005). The lightning discharge in its totality is called a flash (Orville, 1968). One distinguishes between cloud-to-ground (CG) lightning and various other lightning types (which we call IC), including intracloud, intercloud and cloud-to-air lightning. So-called blue jets have been observed above clouds, and sprites and other transient luminescent events occur in the middle atmosphere (Füllekrug et al., 2006). Positive and negative CG flashes (CG+ and CG-) are distinguished depending on whether positive or negative charges are transported from the cloud to the ground. CG+ discharges are less frequent than negative ones, but have larger currents and transfer more charge (Orville, 1994; Lyons et al., 1998b). Lightning occurs typically in a sequence of stages. A CG discharge begins with local dielectric breakdown causing first branched conduction paths inside the cloud. The breakdown initiates conducting channels, e.g. in the form of a "stepped leader" that moves earthward in discrete steps. A large fraction of charge is lowered to the ground within a "return stroke," an intense discharge region that propagates up the stepped leader path from ground to cloud. A flash consists of one or more strokes closely spaced in time travelling along the same discharge channel (Thery, 2001; Saba et al., 2006a). The first stroke is often the most energetic one and assumed to produce the largest amount of 
$\mathrm{LNO}_{\mathrm{x}}$ (Hill, 1979; Dawson, 1980). Large currents also occur in relatively slow discharge processes, such as continuing currents, in both cloud and cloud-to-ground flashes (Rakov and Uman, 2003; Saba et al., 2006b). The flash properties vary from storm to storm and during the lifecycle of a thunderstorm; they depend on the volume and strength of the convective updrafts causing charge separation (Lang and Rutledge, 2002); as well, they depend on the degree of cell isolation and the complexity of cell evolution (MacGorman et al., 2007).

Lightning can be detected from ground and from space using sensors measuring the optical emission, electric radio waves, or magnetic waves resulting from the discharge processes in certain frequency ranges (MacGorman and Rust, 1998). The low frequency (LF, 30-300 kHz), very low frequency (VLF, 3-30 kHz), extremely low frequency (ELF, $30-300 \mathrm{~Hz}$ ), and very high frequency (VHF, 30-300 MHz) bands are employed for lightning detection besides acoustical and optical detection means. Various parts of a flash cause different emissions. The bright spark of light associated with CG lightning stems from the return stroke. Lightning channels behave like a huge antenna which radiates electromagnetic energy as signals of impulsive nature below about $100 \mathrm{kHz}$ (Price et al., 2007). Strong LF radio emission is generated by CG flashes mainly near ground. IC flashes emit multi-pulse bursts of VHF signals from the inner parts of the clouds (Proctor, 1991; Suszcynsky et al., 2000; Thomas et al., 2000). The continuing current between strokes causes small radio wave signals but large reductions in the electric field strength. Most of the ground-based operational lightning detection networks provide two-dimensional (2-D) maps of mainly CG lightning events (Orville et al., 2002) (Table 6). Regionally, within a dense network of detectors, height information is also available (Table 7). The systems use magnetic direction finders (Cummins et al., 1998), time of arrival (Shao and Krehbiel, 1996) or VHF interferometers techniques (Defer et al., 2001) to evaluate the location of the lightning sources. In addition, the duration, and energy or peak current of the flash can be deduced from the measured electromagnetic signals. The peak current is approximately proportional to the amplitude of VLF/LF signals (Orville, 1999; Jerauld et al., 2005; Schulz et al., 2005). Peak current measurements are sensitive to network station spacing; recent measurements show median peak currents of the order of 16-20 kA, smaller than what was estimated earlier (Orville et al., 2002; Biagi et al., 2007).

VHF systems allow for fine-scale observations of the structure of flashes. For example, Fig. 7 shows a lightning discharge observed by the VHF New Mexico Tech Lightning Mapping Array (LMA, see Table 7) (Noble et al., 2004; Thomas et al., 2004; Wiens et al., 2005) during the Severe Thunderstorm Electrification and Precipitation Study (STEPS) (Lang et al., 2004), that illustrates the spatial resolution that the system is able to obtain. Simultaneous data from the National Lightning Detection Network
(NLDN) show that the flash was a multiple-stroke negative CG discharge. The top panel of the figure shows the altitude of the VHF sources versus time and indicates an initial stepped leader initiated between 8 and $9 \mathrm{~km}$ altitude, after about $50 \mathrm{~ms}$ of preliminary breakdown, that required about $60 \mathrm{~ms}$ to reach the ground. Thomas et al. (2004) show that the location accuracy for VHF sources between about 6 and $12 \mathrm{~km}$ altitude over the central part of the network is $<12 \mathrm{~m}$ in horizontal position and $<30 \mathrm{~m}$ in the vertical.

Since the mid 1980s ground-based observations have provided detailed information on the structure of VLF/LF sources radiated by lightning in real time with regional coverage. In many countries lightning detection is routinely performed by means of VLF/LF-networks. Prominent examples are the NLDN in the USA and EUCLID in Europe. These systems report mainly strong ( $>5 \mathrm{kA}$ ) CG strokes (Cummins et al., 1998). Advanced VLF/LF measuring and signal processing techniques detect also IC flashes (Betz et al., 2004; Shao et al., 2006). VLF/LF systems, such as the operational Lightning Location Network (LINET) use refined antenna techniques, optimised waveform handling and shorter sensor base line of $\sim 100 \mathrm{~km}$. Hence, they locate also low-current discharges $(>1 \mathrm{kA})$ and discriminate IC and CG events (Betz et al., 2004). Betz et al. (2007) find a large number of IC signals especially with low current values. The World Wide Lightning Location Network (WWLLN) of VLF-sensors (typically $7000 \mathrm{~km}$ distance) provides quasi global real-time observations; its detection efficiency is low, of the order of $0.3-1 \%$ (Lay et al., 2004; Jacobson et al., 2006).

The Optical Transient Detector (OTD) was, and the Lightning Imaging Sensor (LIS) is, an operational spaceborne camera which detects and locates rapid changes in the brightness of the clouds as they are illuminated by lightning discharges. Both sensors use narrow band optical filtering to select an oxygen triplet line generated by atmospheric lightning centred at $777.4 \mathrm{~nm}$. The narrow band filter reduces daytime background light to a level which allows continuous day/night observation of lightning events. The instruments detect total lightning, since cloud-to-ground, intracloud, and cloud-to-cloud discharges all produce optical pulses that are visible from space. The optical pulses are combined into flashes depending on the temporal and spatial separation; the clustering induces less than $20 \%$ uncertainty in the overall flash counts (Mach et al., 2007). The two sensors cover different latitude bands (OTD: $\pm 75^{\circ}$; LIS: $\pm 35^{\circ} ; \pm 39^{\circ}$ since the satellite (the Tropical Rainfall Measuring Mission, TRMM) was boosted from 350 to $402 \mathrm{~km}$ altitude during August 2001). Depending on cloud thickness and transparency, the detection efficiency (for sufficiently strong flashes) of LIS (OTD) is about $85 \%$ (50\%) on average with weak day/night biases and a local minimum of about $50 \%$ in the region of the South Atlantic anomaly of the geomagnetic field off the coast of Southern Brazil (Boccippio et al., 2000, 2002; Christian et al., 2003). LIS observes an 
Table 6. Selection of operational two-dimensional lightning observation systems.

\begin{tabular}{|c|c|c|c|c|c|c|}
\hline Acronym* & Based at & Observed flash types & $\begin{array}{l}\text { Spatial } \\
\text { coverage }\end{array}$ & $\begin{array}{l}\text { Spatial resolu- } \\
\text { tion, } \mathrm{km}\end{array}$ & Temporal coverage & Reference \\
\hline EUCLID & Ground & $\mathrm{CG}$ & Europe & $<10$ & Continuous since 1998 & $\begin{array}{l}\text { http://www.euclid.org/index.html, } \\
\text { Schulz et al. (2005) }\end{array}$ \\
\hline LINET & Ground & $\mathrm{CG}+\mathrm{IC}$ & $\begin{array}{l}\text { More than } \\
60 \text { stations } \\
\text { in mid- } \\
\text { Europe }\end{array}$ & $<1$ & Continuous since 2006 & Betz et al. (2007) \\
\hline NLDN & Ground & $\mathrm{CG}$ & $\begin{array}{l}\text { North Amer- } \\
\text { ica }\end{array}$ & $<10$ & Continuous since 1998 & Cummins et al. (1998) \\
\hline RINDAT & Ground & $\mathrm{CG}$ & Brazil & $<2$ & Continuous since 1999 & Pinto and Pinto (2003) \\
\hline WWLLN & Ground & CG and some IC & global & 20 & Continuous since 2003 & Lay et al. (2004) \\
\hline OTD & $\begin{array}{l}\text { MicroLab-1 } \\
\text { satellite, } \\
740 \mathrm{~km} \\
\text { altitude }\end{array}$ & $\mathrm{CG}+\mathrm{IC}$ & $75^{\circ} \mathrm{N}-75^{\circ} \mathrm{S}$ & $8-20$ & min day ${ }^{-1}, 1995-1999$ & Christian et al. (2003) \\
\hline LIS & $\begin{array}{l}\text { TRMM satel- } \\
\text { lite, } \quad 350 \mathrm{~km} \\
\text { altitude }\end{array}$ & $\mathrm{CG}+\mathrm{IC}$ & $\begin{array}{l}35^{\circ} \mathrm{N}-35^{\circ} \mathrm{S} \\
\left(39^{\circ} \mathrm{N}-39^{\circ} \mathrm{S}\right. \\
\text { since August } \\
2001)\end{array}$ & 10 & min day $^{-1}$, since 1998 & $\begin{array}{l}\text { Thomas et al. (2000); Christian and } \\
\text { Petersen (2005) }\end{array}$ \\
\hline
\end{tabular}

* EUCLID: European Cooperation for Lightning Detection; LIS: Lightning Imaging Sensor; LINET: Lightning Location Network; NLDN: National Lightning Detection Network; OTD: Optical Transient Detector; RINDAT: Brazilian Integrated Lightning Detection Network; TRMM: Tropical Rainfall Measuring Mission; WWLLN: World Wide Lightning Location Network.

area of $600 \times 600 \mathrm{~km}^{2}$ with a spatial resolution of about $4 \mathrm{~km}$ directly below the satellite, increasing in size to $7 \mathrm{~km}$ on a side at the edges of the field of view (Thomas et al., 2000). Because of higher orbit $(750 \mathrm{~km})$, the field of view and pixel sizes are bout 2.1 times larger for OTD than for LIS (Mach et al., 2007). LIS (OTD) observes each point in the scene for about 90 (190) s, and each point of the Earth for only about a day per year. Nevertheless, they provide statistics with near global coverage (Christian et al., 2003). They derive a counting of total lightning activity but do not discriminate between IC and CG flashes. The counting treats all flashes equally regardless of the intensity, though radiance values are available from the observations as well (Baker et al., 1999). Other spaceborne sensors using VHF radiation have been flown for limited periods (Kotaki and Katoh, 1983), or are operated in an experimental fashion, like the Fast On-Orbit Recording of Transient Events (FORTE) (Boeck et al., 2004; Noble et al., 2004), or have been suggested for future missions (Bondiou-Clergerie et al., 2004). VHF sensors are independent of day/night and ocean/land light differences.

Lightning climatologies have been derived from ground and satellite-based systems for many regions (Brazil, Africa, India, Austria, Germany, Italy, Spain, Japan, China, Tibetan Plateau, Indonesia, Israel, Canada, and the USA), and also for oceans, the Mediterranean Sea, the tropics, hurricanes and mesoscale systems, see Williams (2005), Pinto et al. (2006), and further references (Finke and Hauf, 1996; Molinari et al., 1999; Price and Federmesser, 2006). More- over, mobile lightning detection systems have been used in connection with special observation experiments such as during EULINOX: VHF interferometer (Thery et al., 2000), STERAO: VHF interferometer (Defer et al., 2001), STEPS: LMA (Thomas et al., 2004), TROCCINOX: LINET (Schmidt et al., 2005), SCOUT-O3, TWPICE, and AMMA: LINET. (STEPS provided extensive cloud and lightning observations (Lang et al., 2004) but no air composition measurements.) Figure 8 shows an example of LINET observations as obtained in Southern Brazil during TROCCINOX. Lightning activity is well correlated with radar reflectivity. One can recognize a major line-like oriented convective system with embedded distinct cell centres associated with the majority of the lightning events. The LIS flashes coincide nicely with the LINET stroke clusters.

The global frequency of lightning flashes was first estimated by Brooks (1925) to be of the order of $100 \mathrm{~s}^{-1}$. Later estimates, see Table 8, reached as high as $1600 \mathrm{~s}^{-1}$, partially because of confusion about whether CG or IC or both types of flashes are counted and confusion between the terms "stroke" and "flash" (Rakov and Uman, 2003). The number of strokes (or IC pulses) varies regionally. Global observations are missing, but typical values may be 1.9 for CG flashes and 6 for IC flashes (Borucki and Chameides, 1984). From an aircraft flying above clouds, intracloud flashes were observed to have almost twice as many optical pulses as ground discharges (Goodman et al., 1988). During the EULINOX experiment, average CG- and CG+ flashes were found 
Table 7. Three-dimensional lightning observation systems.

\begin{tabular}{|c|c|c|c|}
\hline System & $\begin{array}{l}\text { ITF: Office National d'Etudes } \\
\text { et de Recherches Aérospatiales } \\
\text { (ONERA) VHF interferometric } \\
\text { mapper }\end{array}$ & $\begin{array}{l}\text { LMA: The New Mexico Tech } \\
\text { Lightning Mapping Array }\end{array}$ & $\begin{array}{l}\text { LINET: Lightning Location Net- } \\
\text { work }\end{array}$ \\
\hline $\begin{array}{l}\text { Frequency } \\
\text { Sampling } \\
\text { interval }\end{array}$ & $\begin{array}{l}\text { VHF: } 1 \mathrm{MHz} \text { band near } 114 \mathrm{MHz} \\
23 \mu \mathrm{s} ; 100 \mu \mathrm{s} \text { in real time }\end{array}$ & $\begin{array}{l}\text { VHF: } 60-66 \mathrm{MHz} \\
50 \mathrm{~ns}\end{array}$ & $\begin{array}{l}\text { VLF/LF: } 5-200 \mathrm{kHz} \\
1 \mu \mathrm{s}\end{array}$ \\
\hline $\begin{array}{l}\text { Number of sta- } \\
\text { tions }\end{array}$ & $\begin{array}{l}2 \text { stations } 40 \mathrm{~km} \text { apart during EU- } \\
\text { LINOX and STERAO-A }\end{array}$ & $\begin{array}{l}13 \text { stations within } 70 \mathrm{~km} \text { diameter } \\
\text { during STEPS }\end{array}$ & $\begin{array}{l}6 \text { sensors in a range of } 100 \mathrm{~km} \\
\text { during TROCCINOX, } 20 \text { sen- } \\
\text { sors within } 100 \mathrm{~km} \text { over Southern } \\
\text { Germany and } \sim 200 \mathrm{~km} \text { otherwise }\end{array}$ \\
\hline $\begin{array}{l}\text { Location tech- } \\
\text { nique }\end{array}$ & Azimuth and elevation angles & $\begin{array}{l}\text { Time of arrival relative to GPS } \\
\text { time reference }\end{array}$ & $\begin{array}{l}\text { Time of arrival relative to Global } \\
\text { Positioning System (GPS) time } \\
\text { reference, and bearing angles } \\
\text { components of magnetic induc- } \\
\text { tion; discrimination of IC and CG } \\
\text { strokes with a three-dimensional } \\
\text { (3-D) procedure from deviations } \\
\text { of arrival times measured at sen- } \\
\text { sor stations close to lightning } \\
\text { events as compared to arrival } \\
\text { times expected on the basis of 2- } \\
\text { D propagation paths }\end{array}$ \\
\hline Detection & $\begin{array}{l}\text { Up to } 4000 \mathrm{~s}^{-1} \text { samples of VHF } \\
\text { radiation emitted along the prop- } \\
\text { agation path of IC or CG dis- } \\
\text { charges, typically } 50-60 \mathrm{~km} \text { for } \\
3 \text {-D and } 120 \mathrm{~km} \text { range for } 2-\mathrm{D} \text { lo- } \\
\text { calisation }\end{array}$ & $\begin{array}{l}\text { Impulsive radio frequency radia- } \\
\text { tion emitted along the propaga- } \\
\text { tion path of IC or CG discharges, } \\
\text { typically } 100 \mathrm{~km} \text { range for } 3-\mathrm{D} \\
\text { localisation, depending on size of } \\
\text { the network }\end{array}$ & $\begin{array}{l}\text { VLF/LF emissions from IC or } \\
\text { CG discharges; typically } 100 \mathrm{~km} \\
\text { range for } 3-\mathrm{D} \text { and } 300 \mathrm{~km} \text { for } 2- \\
\mathrm{D} \text { localisation, depending on size } \\
\text { of the network }\end{array}$ \\
\hline $\begin{array}{l}\text { Location accu- } \\
\text { racy }\end{array}$ & $\begin{array}{l}0.25^{\circ} \text { azimuth, } 0.5^{\circ} \text { elevation at } \\
22^{\circ} \text { elevation }\end{array}$ & $\begin{array}{l}6-12 \mathrm{~m} \text { horizontal, } 20-30 \mathrm{~m} \text { ver- } \\
\text { tical }\end{array}$ & $\begin{array}{l}250 \mathrm{~m} \text { horizontally, in Germany } \\
10-30 \% \text { vertically, inside net- } \\
\text { work }\end{array}$ \\
\hline Reference & $\begin{array}{l}\text { Thery et al. (2000); Defer et } \\
\text { al. (2001); Thery (2000) }\end{array}$ & Thomas et al. (2004) & $\begin{array}{l}\text { Betz et al. (2004, 2007); Schmidt } \\
\text { et al. (2005) }\end{array}$ \\
\hline
\end{tabular}

to be composed of 2.8 and 1.2 strokes, respectively (Thery, 2001).

The knowledge of the global distribution of lightning has improved strongly since the advent of space-based lightning observations. Observations with OTD (and ongoing observations with LIS (Christian and Petersen, 2005)) (see Table 6) indicate a global flash rate of $44 \pm 5 \mathrm{~s}^{-1}$ (Christian et al., 2003). The LIS data for the years 1998-2005 reveal annual mean values of $40.2 \pm 4 \mathrm{~s}^{-1}$ for the latitude band $\pm 35^{\circ}$ (A. Schady, personal communication, 2007). The OTD data show that higher latitudes (up to $\pm 78^{\circ}$ ) contribute about $14 \%$ to the global mean lightning activity. Hence, the global mean value may possibly reach $47 \pm 5 \mathrm{~s}^{-1}$, consistent with recent estimates of the LIS investigators (D. Buechler, personal communication, 2007).
Lightning occurs mainly over land areas (see Fig. 9), with an average land/ocean ratio of about 6 to 10. (The precise ratio depends on the satellite used, on the resolution of the land mask, and on how coastal areas are assigned to land or ocean). Approximately $77 \%$ of all lightning occurs between $30^{\circ} \mathrm{S}$ and $30^{\circ} \mathrm{N}$, see Fig. 10. The flash rate is a maximum over the Congo basin with annual mean flash density of $80 \mathrm{~km}^{-2} \mathrm{a}^{-1}$. Over Brazil and Florida the density reaches $30 \mathrm{~km}^{-2} \mathrm{a}^{-1}$, and over Northern Italy, for comparison, it stays below 10 flashes $\mathrm{km}^{-2} \mathrm{a}^{-1}$ (Christian et al., 2003). For Germany, a value of $2.8 \mathrm{~km}^{-2} \mathrm{a}^{-1}$ (mainly CG) has been reported based on a ground-based lightning location system (Finke and Hauf, 1996). In the tropics, regions with lightning activity may extend over several thousands of kilometres (Nickolaenko et al., 2006). Globally, most flashes 
Table 8. Lightning flash rate (total, cloud-to-ground, and stroke rate).

\begin{tabular}{|c|c|c|c|c|}
\hline $\begin{array}{l}\text { Flash rate } \\
\left(s^{-1}\right)\end{array}$ & CG flash rate & $\begin{array}{l}\text { Stroke } \\
\text { rate }\end{array}$ & Method & Reference \\
\hline 100 & - & - & $\begin{array}{l}\text { Estimate assuming } 1800 \text { ac- } \\
\text { tive thunderstorms, each } \\
\text { lasting } 1 \mathrm{~h} \text { and causing } 200 \\
\text { flashes }\end{array}$ & Brooks (1925); Mackerras et al. (1998) \\
\hline 400 & 100 & 1600 & $\begin{array}{l}\text { Review and extrapolations } \\
\text { based on the energy dissi- } \\
\text { pated by lightning }\end{array}$ & Chameides et al. (1977); Chameides (1979a) \\
\hline $123 \pm 60$ & - & - & $\begin{array}{l}\text { Photographs from two } \\
\text { DMSP satellites at dusk }\end{array}$ & Orville and Spencer (1979) \\
\hline 300 & 60 & - & Review & Kowalczyk and Bauer (1981) \\
\hline $80 \pm 40$ & - & - & $\begin{array}{l}\text { Photodetector on a DMSP } \\
\text { satellite recording lightning } \\
\text { at dawn and dusk }\end{array}$ & Turman and Edgar (1982) \\
\hline $63 \pm 30$ & - & - & $\begin{array}{l}\text { High-frequency radio re- } \\
\text { ceivers on the Japanese } \\
\text { Ionosphere Sounding Satel- } \\
\text { lite (ISS-b) satellite }\end{array}$ & Kotaki and Katoh (1983) \\
\hline 65 & $10-14$ & - & $\begin{array}{l}\text { Combining DMSP, ISS-b, } \\
\text { ground-based observations, } \\
\text { and a model }\end{array}$ & Mackerras et al. (1998) \\
\hline $44 \pm 5$ & - & - & $\begin{array}{l}\text { from OTD data and a } \\
\text { continuous nine-year record } \\
\text { of global lightning activity } \\
\text { from LIS and OTD }\end{array}$ & Christian et al. (2003); Christian and Petersen (2005) \\
\hline
\end{tabular}

occur during the Northern Hemisphere summer (about 1.2 times more than in winter, because of larger land fraction in the Northern Hemisphere). There is a distinct seasonal and diurnal cycle. Over land, with the daily cycles of thunderstorm convection, lightning peaks clearly in the afternoon hours between 14 and 18 local time, while being less variable over oceans (Hendon and Woddberry, 1993; Finke and Hauf, 1996; Williams et al., 2000; Dai, 2001; Ricciardulli and Sardeshmukh, 2002; Soriano et al., 2006); minimum of lightning activity occurs in the morning, at 6-8 local time (Nickolaenko et al., 2006), see Fig. 11.

Lightning activity increases dramatically with the depth and the vigour of convection (in particular updraft velocity) which is particularly pronounced over the tropical continents (Williams, 1985; Zipser et al., 2006). Lhermitte and Krehbiel (1979) using a network of three Doppler radars and groundbased lightning detection systems demonstrated that the total lightning flash rate correlates with in-cloud updraft velocity. Lightning is absent or highly unlikely if the updraft speed does not exceed a threshold of roughly $6-7 \mathrm{~m} \mathrm{~s}^{-1}$ (mean) or 10-12 $\mathrm{m} \mathrm{s}^{-1}$ (peak), regardless of cloud depth (Zipser, 1994; Zipser and Lutz, 1994). Case studies show that the strongest
$10 \%$ of convective updraft cores (including those in most of the intense hurricanes) have average vertical velocities exceeding $4-5 \mathrm{~m} \mathrm{~s}^{-1}$ over oceans, compared to $12-13 \mathrm{~m} \mathrm{~s}^{-1}$ over land (Jorgenson and LeMone, 1989; Lucas et al., 1994b; Williams and Stanfill, 2002; Anderson et al., 2005). Certain supercell and multicell storms over land reach updraft velocities up to about $80 \mathrm{~m} \mathrm{~s}^{-1}$ (Cotton and Anthes, 1989; Lang et al., 2004; Mullendore et al., 2005; Chaboureau et al., 2007). Some ground-based radar and lightning observations indicate that the flash frequency increases with cloud top height (Williams, 1985, 2001). However, even for the same cloud top brightness temperature, size and radar reflectivity, satellite data indicate that storms over water produce less lightning than comparable storms over land (Cecil et al., 2005).

The higher flash ratio over land is explained by more intense convection ("thermal hypothesis") (Williams, 2005). Most oceanic storms have updrafts which are too weak to induce sufficiently ice and supercooled water for electrification (Zipser, 1994; Toracinta et al., 2002). The amount of convective available potential energy (CAPE) is similar over land and oceans. However oceanic updrafts achieve a 
Table 9. Intra-cloud/cloud-to-ground flash number ratio.

\begin{tabular}{lll}
\hline IC/CG flash number ratio & Method & Author \\
\hline $3.35(2-6)$ & $\begin{array}{l}\text { Satellite and ground observations. The } \\
\text { bracket lists the possible range of values. }\end{array}$ & Prentice and MacKerras (1977) \\
\hline 5 & $\begin{array}{l}\text { Review } \\
\text { Satellite and ground observations }\end{array}$ & $\begin{array}{l}\text { Kowalczyk and Bauer (1981) } \\
\text { Proctor (1991) }\end{array}$ \\
\hline $2.6-4$ & Ground-based lightning observations & Mackerras and Darvenzina (1994) \\
\hline 4.3 & Review & Price et al. (1997b) \\
\hline $4.4 \pm 1$ & Satellite and ground observations & Mackerras et al. (1998) \\
\hline $2.8 \pm 1.4(1-9)$ & $\begin{array}{l}\text { OTD and NLDN data over the continen- } \\
\text { tal USA. The bracket lists extreme mean } \\
\text { values at various stations. }\end{array}$ & Boccippio et al. (2001) \\
\hline $2 \pm 0.6(0.75-7.7)$ & $\begin{array}{l}\text { Data from OTD, LIS, and ground-based } \\
\text { lightning detection instruments denoted } \\
\text { CIGRE-500 and CGR3, over Australia. }\end{array}$ & Kuleshov et al. (2006) \\
& $\begin{array}{l}\text { The bracket lists extreme mean values at } \\
\text { various stations. }\end{array}$ & \\
\hline $3.5(0-12)$ & $\begin{array}{l}\text { Data from OTD and a ground-based light- } \\
\text { ning detection network over Spain. The } \\
\text { bracket lists the spatial variability of the } \\
\text { mean values over the Iberian peninsula. }\end{array}$ & \\
\hline
\end{tabular}

lower fraction of their potentially available updraft velocities because of higher water loading (reducing buoyancy), more lateral entrainment, less buoyancy at low levels (Lucas et al., 1994a), and lower cloud base (Lucas et al., 1994b; Mushtak et al., 2005; Williams et al., 2005). The higher cloud base over land correlates with larger scales in the boundary layer, wider updrafts, less entrainment, and larger ice content above the freezing level (Lucas et al., 1994b; Zipser and Lutz, 1994; Williams and Stanfill, 2002).

Differing aerosol concentrations have also been proposed as a factor on the observed land-ocean contrasts ("aerosol hypothesis") (Takahashi, 1984; Molinié and Pontikis, 1995; Rosenfeld and Lensky, 1998; Steiger et al., 2002; Williams et al., 2002; Andreae et al., 2004). Wet land regions, like the Amazon basin in the wet season, act like a "green ocean" with reduced lightning activity (Williams et al., 2002). The presumed role of increased aerosol concentration is a reduced mean droplet size, narrower cloud droplet spectra, deeper mixed phase region in the cloud, additional charge separation in this region, enhanced lightning downwind of the aerosol source, and reduced particle sizes of ice crystals (Lyons et al., 1998a; Sherwood et al., 2006). Aerosols also impact the electrical conductivity of the atmosphere (Rycroft et al., 2000). A microphysical model study shows that different boundary layer aerosol causes differences in cloud condensation nuclei $(\mathrm{CCN})$, which influences thunderstorm charging (Mitzeva et al., 2006). Recent experiments provide mixed support for the idea that smoke aerosols may impact CG polarity, and suggest a possible link between drought conditions and lightning properties instead (Lang and Rutledge, 2006). Sensitivity of lightning to natural ground radioactivity (Rakov and Uman, 2003), and to cosmic rays and the solar cycle has been also considered (Rycroft et al., 2000; Williams, 2005), but such influences are difficult to detect (Harrison, 2006). An analysis of the annual number of thunder days versus island area gives more support to the thermal than the aerosol hypothesis (Williams and Stanfill, 2002). Also the invariance of lightning activity for two months with high and low aerosol concentrations over the Amazon region casts doubt on a primary role for the aerosol enhancing the electrification (Williams et al., 2002). Simply speaking, land lightning is dominant because land is hotter than ocean (Williams and Stanfill, 2002).

Observations of the strength or size of convective updrafts do not exist worldwide. Weather analysis data indicate the global distribution of intense storms (Brooks et al., 2003). Proxies for convective intensity are given by satellite data of minimum passive microwave brightness temperature (at 37 and $85 \mathrm{GHz}$ ), maximum vertical extent of radar reflectivity values (e.g., 20 or $40 \mathrm{dBZ}$ ), and maximum radar reflectivity at some height level (e.g. $>6.5 \mathrm{~km})$. Such data are available from the TRMM satellite in the tropics. Global data are available from the $85-\mathrm{GHz}$ passive microwave sensor on a Defence Meteorological Satellite Program (DMSP) 
Table 10. Enhancements of $\mathrm{NO}$ and $\mathrm{NO}_{\mathrm{x}}$ mixing ratios measured in situ near thunderstorms.

\begin{tabular}{|c|c|c|c|c|c|c|c|c|c|}
\hline Year & Project, region & Instrument & Species & $\begin{array}{l}\text { Mean, } \\
\text { nmol mol }^{-1}\end{array}$ & $\begin{array}{l}\text { Mean } \\
\text { scale } \\
(2), \mathrm{km}\end{array}$ & $\begin{array}{l}\text { Peak, } \\
\text { nmol mol}^{-1}\end{array}$ & $\begin{array}{l}\text { Peak du- } \\
\text { ration }\end{array}$ & $\begin{array}{l}\text { Peak alti- } \\
\text { tude, km }\end{array}$ & Reference \\
\hline$\sim 1960 \mathrm{~s}$ & $\begin{array}{l}\text { Wank mountain station in } \\
\text { Southern Germany }\end{array}$ & $\mathrm{KI}$ & $\mathrm{NO}_{2}$ & - & - & $\begin{array}{l}\sim 3 \\
<50\end{array}$ & unknown & $\begin{array}{l}1.7 \\
\text { mountain }\end{array}$ & Reiter (1970) \\
\hline April 1981 & Argonne, Illinois & $\mathrm{CL}$ & $\mathrm{NO}_{\mathrm{x}}$ & - & - & 20 & $40 \mathrm{~s}$ & ground & Drapcho et al. (1983) \\
\hline Dec 1982 & $\begin{array}{l}\text { Flight Frankfurt }- \text { Sao } \\
\text { Paulo }\end{array}$ & $\mathrm{CL}$ & $\mathrm{NO}_{\mathrm{x}}$ & 0.3 & $>100$ & 0.5 & $\sim \min$ & 9.5 & Dickerson (1984) \\
\hline Nov 1983 & $\begin{array}{l}\text { GTE/CITE 1A, Pacific } \\
\text { near Hawaii }\end{array}$ & TP-LIF & $\mathrm{NO}$ & 1 & 40 & 1 & $2 \min$ & 9 & $\begin{array}{l}\text { Chameides et al. } \\
(1987) ; \quad \text { Davis et } \\
\text { al. (1987) }\end{array}$ \\
\hline 1983 & Midwest USA, & $\mathrm{CL}$ & $\mathrm{NO}_{\mathrm{x}}$ & 0.6 & - & 1.2 & $10 \mathrm{~s}$ & $10-11$ & $\begin{array}{l}\text { Dickerson et al. } \\
\text { (1987) }\end{array}$ \\
\hline June 1985 & $\begin{array}{l}\text { PRE-STORM, Great } \\
\text { Plains, Colorado }\end{array}$ & $\mathrm{CL}$ & $\mathrm{NO}$ & 0.3 & - & $\begin{array}{l}1.2 \\
4.1\end{array}$ & $\begin{array}{l}20-60 \mathrm{~s}, \\
10 \mathrm{~s}\end{array}$ & 10.6 & Luke et al. (1992) \\
\hline $\begin{array}{ll}12 & \text { July } \\
1985 & \end{array}$ & $\begin{array}{l}\text { GTE/ABLE 2A, Amazo- } \\
\text { nia, near Manaus, Brazil }\end{array}$ & $\mathrm{CL}$ & $\mathrm{NO}$ & 0.06 & $60-100$ & 0.17 & $5-40 s$ & 5 & Torres et al. (1988) \\
\hline June 1989 & NDTP, North Dakota & $\mathrm{CL}$ & NO & 0.25 & & 0.9 & $20 \mathrm{~s}$ & 11 & Poulida et al. (1996) \\
\hline $\begin{array}{l}\text { July-Aug } \\
1989\end{array}$ & ELCHEM, New Mexico & $\mathrm{CL}$ & NO & $0.1-0.8$ & $20-44$ & $1.3-1.9$ & $4 \mathrm{~s}$ & $10.5-10.9$ & $\begin{array}{l}\text { Ridley et al. (1994, } \\
1996)\end{array}$ \\
\hline $\begin{array}{ll}27 & \text { Sep } \\
1992 & \end{array}$ & $\begin{array}{l}\text { GTE/TRACE A, } \\
\text { Brazilian cerrado, } 6^{\circ}- \\
12^{\circ} \mathrm{S}\end{array}$ & TP-LIF & $\mathrm{NO}_{\mathrm{x}}$ & $0.3-0.9$ & - & 1.4 & $3 \min$ & 9.5 & Pickering et al. (1996) \\
\hline Feb 1994 & $\begin{array}{l}\text { PEM-West, West Pacific, } \\
4^{\circ}-10^{\circ} \mathrm{S}\end{array}$ & $\mathrm{CL}$ & NO & $0.05-0.2$ & $\sim 100$ & 0.2 & $30 \mathrm{~s}$ & 9.5 & $\begin{array}{l}\text { Kawakami et al. } \\
\text { (1997) }\end{array}$ \\
\hline 1 July 1995 & POLINAT, Ireland & $\mathrm{CL}$ & NO & 0.6 & $27-90$ & & & 9.5 & $\begin{array}{l}\text { Huntrieser et al. } \\
\text { (1996) }\end{array}$ \\
\hline $\begin{array}{l}\text { June-July } \\
1996\end{array}$ & STERAO, Colorado & $\mathrm{CL}$ & $\mathrm{NO}$ & $0.2-0.8$ & $20-40$ & $4.2,19$ & $\begin{array}{l}1-10 \mathrm{~s}, \\
(100- \\
960 \mathrm{~m})\end{array}$ & $7-12$ & $\begin{array}{l}\text { Dye et al. (2000); } \\
\text { Stith et al. (1999) }\end{array}$ \\
\hline July 1996 & $\begin{array}{l}\text { LINOX, Southern Ger- } \\
\text { many }\end{array}$ & $\mathrm{CL}$ & $\begin{array}{l}\mathrm{NO} \\
\mathrm{NO}_{\mathrm{x}}\end{array}$ & $\begin{array}{l}0.4-1.3 \\
0.8-2.2\end{array}$ & $10-45$ & $3.8,20$ & $2 \mathrm{~s}$ & $8.2,9$ & $\begin{array}{l}\text { Huntrieser et al. } \\
\text { (1998) }\end{array}$ \\
\hline $\begin{array}{ll}\text { Aug, Nov } \\
1997\end{array}$ & $\begin{array}{l}\text { NOXAR/POLINAT-2, } \\
\text { North Atlantic }\end{array}$ & $\mathrm{CL}$ & $\mathrm{NO}$ & $\begin{array}{l}0.8 \\
3\end{array}$ & $\begin{array}{l}1000 \\
300\end{array}$ & & & & Jeker et al. (2000) \\
\hline July 1998 & $\begin{array}{l}\text { EULINOX, Southern Ger- } \\
\text { many }\end{array}$ & $\mathrm{CL}$ & $\mathrm{NO}_{\mathrm{x}}$ & $0.5-3.0$ & $15-60$ & $\begin{array}{l}25, \text { often } \\
>20\end{array}$ & $2-10 \mathrm{~s}$ & $8-10$ & $\begin{array}{l}\text { Huntrieser et al. } \\
\text { (2002) }\end{array}$ \\
\hline July 1998 & $\begin{array}{l}\text { STREAM, Ontario, } \\
\text { Canada }\end{array}$ & $\mathrm{CL}$ & $\mathrm{NO}$ & $0.6-2$ & 100 & 2.5 & $1 \mathrm{~min}$ & 10 & Lange et al. (2001) \\
\hline Sep 1999 & $\begin{array}{l}\text { BIBLE, Pacific between } \\
\text { Darwin and Biak }\end{array}$ & $\mathrm{CL}$ & NO & $0.1-0.3$ & 800 & 1.4 & $1 \mathrm{~s}$ & 13 & Kondo et al. (2003b) \\
\hline $\begin{array}{l}\text { March } \\
2000\end{array}$ & $\begin{array}{l}\text { INCA, west coast South } \\
\text { America }\end{array}$ & $\mathrm{CL}$ & NO & $0.04-0.8$ & 400 & 1.3 & $1 \mathrm{~s}$ & 11.5 & Baehr et al. (2003) \\
\hline 9 Dec 2000 & $\begin{array}{l}\text { BIBLE C, near Darwin, } \\
\text { Australia }\end{array}$ & $\mathrm{CL}$ & $\mathrm{NO}_{\mathrm{x}}$ & 0.4 & $\begin{array}{l}140- \\
620\end{array}$ & 1.6 & $10 \mathrm{~s}$ & $11.5-14$ & Koike et al. (2007) \\
\hline July 2002 & CRYSTAL FACE, Florida & $\mathrm{CL}$ & NO & $1-4$ & $60-120$ & $\begin{array}{l}9.5 \\
325^{(3)}\end{array}$ & $0.3 \mathrm{~s}$ & 13.8 & $\begin{array}{l}\text { Ridley et al. (2004, } \\
\text { 2006) }\end{array}$ \\
\hline $\begin{array}{l}\text { Jan-March } \\
2004, \\
\text { Feb } 2005\end{array}$ & $\begin{array}{l}\text { TROCCINOX, Brazil, } \\
\text { State of Sao Paulo }\end{array}$ & $\mathrm{CL}$ & NO & $0.5-1.5$ & $25-40$ & 45 & $1 \mathrm{~s}$ & 8 & $\begin{array}{l}\text { Schumann et al. } \\
\text { (2004b); Huntrieser et } \\
\text { al. (2007) }\end{array}$ \\
\hline
\end{tabular}

(1) $\mathrm{CL}$ : Chemiluminescence from the reaction of $\mathrm{NO}+\mathrm{O}_{3}$; KI: Method on the basis of a chemical reaction between $\mathrm{NO}_{2}$ gas and a diluted $\mathrm{KI}$ solution; TP-LIF: two-photon laser-induced fluorescence.

(2) Horizontal mean scale of mean $\mathrm{NO}$ or $\mathrm{NO}_{\mathrm{x}}$ enhancements; -: no information available; if only one value is given, the information available is insufficient (or has not yet been evaluated in detail) to specify a range.

(3) Likely due to hot or cold discharges occurring on the aircraft fuselage or air sampling system (Ridley et al., 2006).

www.atmos-chem-phys.net/7/3823/2007/

Atmos. Chem. Phys., 7, 3823-3907, 2007 


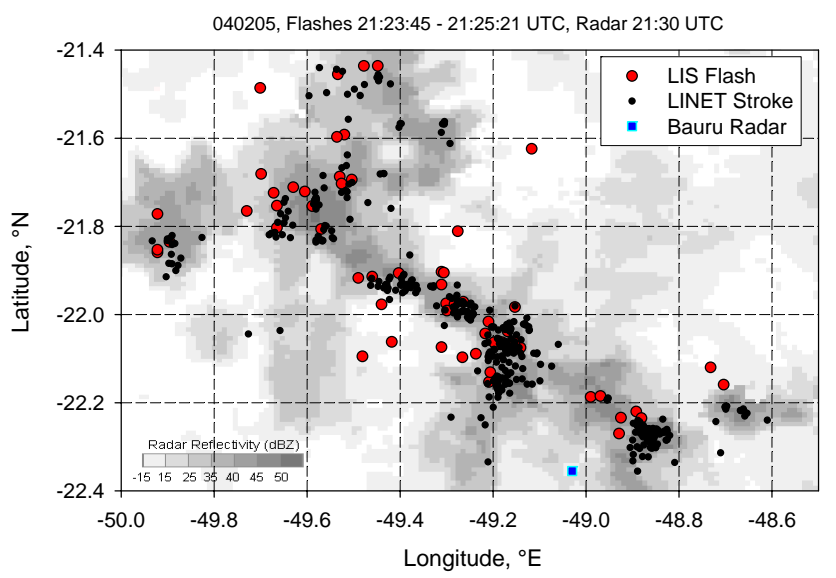

Fig. 8. Horizontal distribution of precipitation and lightning activity near Bauru, Brazil, between $21.4^{\circ}-22.4^{\circ} \mathrm{S}$ and $48.5^{\circ}-50.0^{\circ} \mathrm{W}$, during the TROCCINOX experiment on 4 February 2005, near 21:30 UT (19:30 local time), when the TRMM satellite passed over this region. The radar image of 21:30 UTC shows maximum radar reflectivity in the vertical (max-CAPPI) as obtained from the volume scan composite of two operational C-band Doppler weather radars of the Instituto de Pesquisas Meteorológicas (IPMET), located at Bauru and Presidente Prudente. The red symbols denote the positions of lightning flashes observed with the LIS sensor from TRMM in the time window from 21:23:45 to 21:25:21. Black dots denote horizontal positions of individual lightning strokes identified by the LINET system (at any altitude) in the same time window. (Figure provided by H. Höller, DLR, using data from the LIS sensor aboard the TRMM satellite as provided by NASA, data from the LINET system set up in cooperation with the Sferics group of H.-D. Betz at the University of Munich (LMU), and radar data from the team of G. Held, IPMET, Bauru, Sao Paulo, Brazil).

polar orbiting satellite (Zipser et al., 2006). The TRMM data have been used to identify precipitation features (PF). A PF is a contiguous region of precipitation. For example, Fig. 12 shows the locations of PFs with strong lightning activity (Cecil et al., 2005; Cecil, 2006). As nicely illustrated by Zipser et al. (2006), only about $1 \%$ of all PFs reach flash rates greater than about $3 \mathrm{~min}^{-1}$, with a few extremes up to $1360 \mathrm{~min}^{-1}$. Zipser et al. (2006) further note: The most extreme of such convective events occur over the United States, Argentina, Congo, and parts of the Indian Subcontinent while strong storms in these measures are rare over the tropical oceans; the most intense storms over oceans occur adjacent to land, in locations favouring storm motion from land to ocean; strong convective storms are often found in semiarid regions. Tropical clouds with heavy rain over the oceans or parts of the monsoon of the Indian subcontinent show rather low flash rates; areas of intense storms in the central United States and southeast South America coincide with regions where huge mesoscale convective systems (MCS) occur frequently (Laing and Fritsch, 1997; Houze, 2004). These are regions with strong low-level wind shear and low-level transport of very moist air and mid-level disturbances which may lift the low-level air and initiate release of convective instability.

Operational ground-based detection systems like the NLDN in the USA observe mainly CG flashes while the OTD/LIS sensors observe more or less all flashes. Hence, the IC/CG flash ratio can be derived from the ratio of both observations, see Fig. 13 (Boccippio et al., 2001). Most studies suggest a global annual mean IC/CG flash ratio $f_{\mathrm{IC}} / f_{\mathrm{CG}}$ of about 2 to 4 , see Table 9. The ratio increases with the total flash density (Soriano and de Pablo, 2007), with values exceeding 50 in intensive individual storms (Dye et al., 2000; Thery, 2001; Wiens et al., 2005). A latitudinal dependence of the IC/CG flash ratio has been suggested in many studies (Pierce, 1970; Prentice and MacKerras, 1977). Traditional studies related this ratio to the freezing level in the atmosphere. Boccippio et al. (2001) find little evidence for a latitude dependence but stronger dependence on ground elevation; however, the IC/CG ratio was found to depend far more on storm intensity, morphology, and level of organization than on latitude, freezing-level height, troposphere depth, or surface elevation. More recent studies identify high cloud tops, and low cloud bases with narrow updrafts as supportive for high IC/CG ratios (Mushtak et al., 2005).

Interannual variability of lightning is large regionally. For the contiguous USA, 3 years of total CG lightning varied by 6-20\% from year to year (Orville, 1994); similarly for Germany, 4 years of data show interannual variations of 8 30\% (Finke and Hauf, 1996). The total set of 10 years of LIS/OTD data 1996-2005 shows an interannual variability of globally averaged lightning activity of about $\pm 4 \%$ for annual and $\pm(4-9) \%$ for monthly mean values; for LIS 2000-2005, the interannual variability is smaller $( \pm 1.7 \%$ for the annual mean); and a systematic trend cannot be detected over the years 1996-2005 from the total set of 10 years of LIS/OTD data (A. Schady, personal communication, 2007).

OTD data together with ground-based lightning statistics have been used to estimate the seasonal and global distribution of $\mathrm{LNO}_{\mathrm{x}}$ production for given flash-specific $\mathrm{LNO}_{\mathrm{x}}$ production values (Nesbitt et al., 2000; Bond et al., 2001, 2002), similar to Fig. 2.

\subsection{Observations of $\mathrm{NO}_{\mathrm{x}}$ from lightning}

A few years after Benjamin Franklin published his findings on lightning (Franklin, 1774; Uman, 1987), Henry Cavendish performed the first experiments with a spark discharge in a glass tube (Cavendish, 1785). While trying to distinguish the different constituents of air, he succeeded in identifying oxidised nitrogen compounds as a product of the burning of air in the discharge. Approximately half a century later, von Liebig (1827) discovered nitric acid in different samples of rain water. Being aware of the work performed by Cavendish, he related this to the formation of $\mathrm{NO}_{\mathrm{x}}$ by lightning, followed by an oxidation in rainwater. Von Liebig 


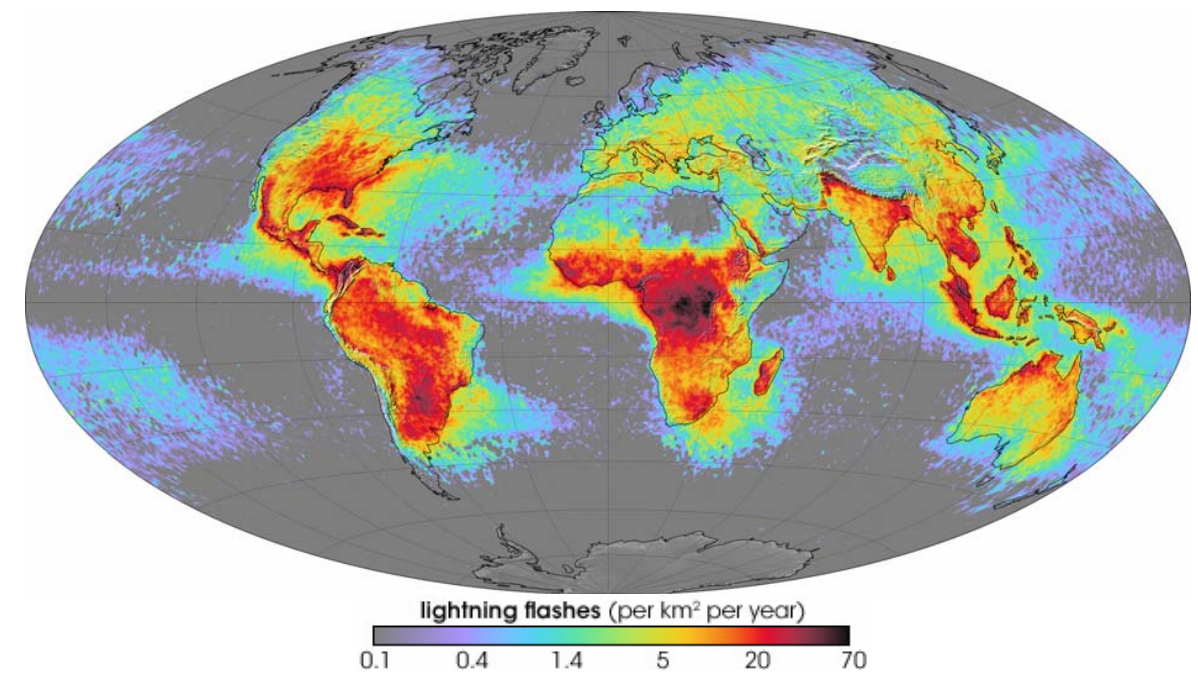

Fig. 9. Global distribution of annually averaged lightning flash frequency density derived from data of LIS between 1997 and 2002 , and OTD between 1995 and 2000 (from NASA's Global Hydrology and Climate Center at Marshall Space Flight Center, 2006). The maximum and global mean flash density values are $\sim 80 \mathrm{~km}^{-2} \mathrm{a}^{-1}$ and $2.7 \pm 0.3 \mathrm{~km}^{-2} \mathrm{a}^{-1}$, respectively.

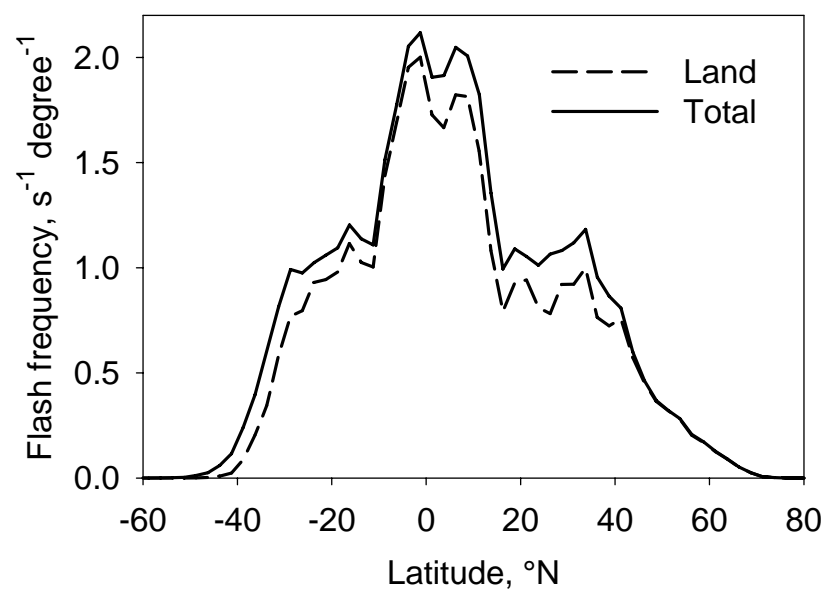

Fig. 10. Mean flash frequency (totally and over land) per degree versus latitude (mean frequency $43.3 \mathrm{~s}^{-1}$; total land/sea flash frequency ratio: 6.5), computed from the five-year (April 1995-March 2000) OTD 2.5 Degree Low Resolution Diurnal Climatology data, counting all $2.5^{\circ} \times 2.5^{\circ}$ grid cells with more than $2 \%$ land fraction as land cells. The gridded satellite lightning data were produced by the NASA LIS/OTD Science Team (Principal Investigator, H. J. Christian, NASA/Marshall Space Flight Center) and are available from the Global Hydrology Resource Center (http://ghrc.msfc.nasa.gov).

already pointed out, that the oxidation by lightning may play a significant role in the global $\mathrm{NO}_{\mathrm{x}}$ budget. Various investigations in the 19th and 20th century tried to quantify this role, but the general result was that the concentration of nitric acid in rainwater and lightning correlated poorly (Hutchinson, 1954; Viemeister, 1960; Reiter, 1970). Neither $\mathrm{NO}$ nor $\mathrm{NO}_{2}$ are water soluble and the long time required

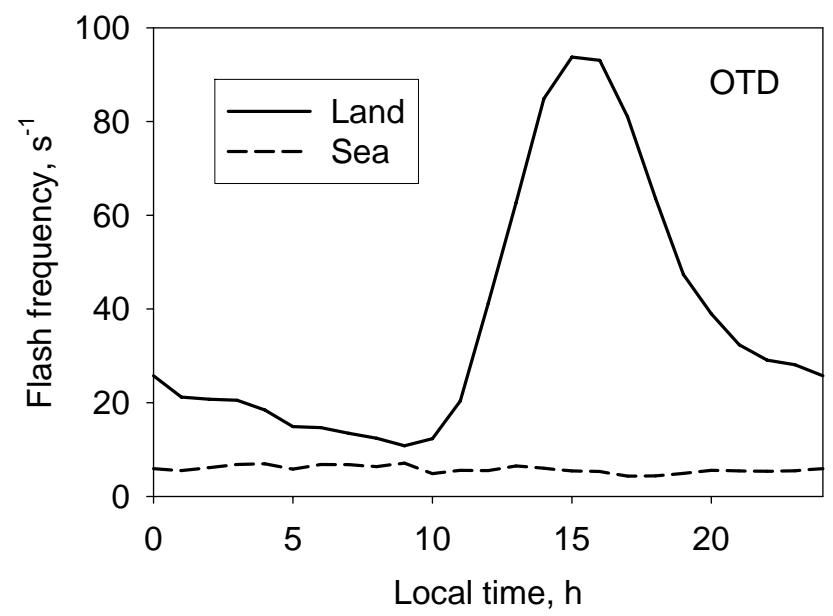

Fig. 11. Mean diurnal variation of the OTD flash frequency over land and over sea versus local time, computed from the same data as in Fig. 6 (mean frequency $37.6 \mathrm{~s}^{-1}$ over land, $5.8 \mathrm{~s}^{-1}$ over sea; $43.3 \mathrm{~s}^{-1}$ total).

to convert $\mathrm{NO}_{\mathrm{x}}$ to nitric acid explains the missing correlation between lightning and nitrate deposition (Tuck, 1976). It was concluded that the production of oxidised nitrogen compounds due to lightning is negligible compared to anthropogenic and biogenic sources (Viemeister, 1960). These findings lead temporarily to a lack of interest in the interaction of atmospheric chemistry and lightning. The growing awareness on the important influence of tropospheric and stratospheric $\mathrm{NO}_{\mathrm{x}}$ on atmospheric chemistry (HaagenSmit et al., 1953; Crutzen, 1970; Johnston, 1971; Chameides and Walker, 1973) renewed the interest in the interaction 
of lightning and atmosphere. Early estimates of very high $\mathrm{LNO}_{\mathrm{x}}$ contributions triggered intensive discussions and further investigations.

The production of NO by lightning is described by the Zel'dovich mechanism of $\mathrm{O}_{2}$ and $\mathrm{N}_{2}$ dissociation and subsequent NO formation in the initially very hot lightning channel (Zel'dovich and Raizer, 1967; Goldenbaum and Dickerson, 1993). Because of lower bond dissociation energy of $\mathrm{O}_{2}\left(0.50 \mathrm{MJ} \mathrm{mol}^{-1}\right)$ compared to that of $\mathrm{N}_{2}\left(0.94 \mathrm{MJ} \mathrm{mol}^{-1}\right)$ (Howard and Rees, 1996), oxygen molecules dissociate first. Peak temperatures in excess of $30000 \mathrm{~K}$ are reached in lightning return strokes after a few microseconds, mainly by ohmic heating (Orville, 1968; Stark et al., 1996; MacGorman and Rust, 1998). After cooling to about 3000-4000 K by expansion, radiation and conduction, the channel contains a plasma with high concentrations (order of 1-20\%) of O, NO, OH, NO and N radicals (Hill, 1977; Bhetanabhotla et al., 1985). The rapid cooling of the hot channel by mixing with ambient air in the next milliseconds "freezes out" the NO content, i.e. prevents the NO produced undergoing thermal decay reactions (Chameides, 1979a; Hill et al., 1980; Bhetanabhotla et al., 1985). Lightning may also induce some $\mathrm{NO}_{2}$ with the $\mathrm{NO}_{2} / \mathrm{NO}_{\mathrm{x}}$ ratio of 0.5 to 0.1 , decreasing with the water content of the air (Franzblau, 1991; Stark et al., 1996). As explained before, the NO reacts in the atmosphere with $\mathrm{O}_{3}$ to form $\mathrm{NO}_{2}$ quickly. Recently, Rahman et al. (2007) investigated $\mathrm{NO}_{\mathrm{x}}$ produced by rocket-triggered lightning. They suggest that relatively slow discharge processes, those occurring on time scales of milliseconds to hundreds of milliseconds, such as continuing currents in both cloud and cloud-to-ground flashes and other steady currents, with quasi-steady currents of the order $100 \mathrm{kA}$, contribute significantly to the global $\mathrm{LNO}_{\mathrm{x}}$ production.

Lightning contributions to $\mathrm{NO}_{\mathrm{x}}$ in the atmosphere have been evidenced in many experiments. Mean and peak enhancements of $\mathrm{NO}$ (or $\mathrm{NO}_{2}$ or $\mathrm{NO}_{\mathrm{x}}$ ) mixing ratios observed in lightning-influenced air masses are listed in Table 10. Lightning-induced $\mathrm{NO}_{2}$ was detected for the first time by Reiter (1970) with in-situ measurements at a mountain station with peak mixing ratios of $50 \mathrm{nmol} \mathrm{mol}^{-1}$ during the passage of 17 thunderstorms. A few years later, Noxon (1976) measured $\mathrm{NO}_{2}$ by optical absorption of solar light from ground and found an enhancement of the column concentration of $\mathrm{NO}_{2}$ by a factor of 100 to 500 , which he attributed to $\mathrm{LNO}_{\mathrm{x}}$ from thunderstorms in the vicinity. For a specific thunderstorm producing five strokes per minute within a radius of $3 \mathrm{~km}$ from the observatory, the derived $\mathrm{NO}_{2}$ column concentration reached $2.5 \times 10^{17} \mathrm{~cm}^{-2}$, with peak $\mathrm{NO}_{2}$ mixing ratios far higher than the column average of $12 \mathrm{nmol} \mathrm{mol}^{-1}$. Dickerson (1984) performed airborne insitu measurements of $\mathrm{NO}_{\mathrm{x}}$ and found enhanced $\mathrm{NO}_{\mathrm{x}}$ in wide $(>100 \mathrm{~km})$ plumes at about $10 \mathrm{~km}$ altitude during a flight from Frankfurt to São Paulo along the eastern coast of Brazil in December 1982 (Dickerson, 1984); the $\mathrm{NO}_{\mathrm{x}}$ increases were attributed to biomass burning and possibly lightning.
During the NASA GTE/CITE 1 fall 1983 airborne field experiment near Hawaii local increases of $\mathrm{NO}_{\mathrm{x}}$ abundance due to lightning were identified (Chameides et al., 1987; Davis et al., 1987).

Since then a series of experiments performed measurements close to or within thunderstorms over the USA (Dickerson et al., 1987; Luke et al., 1992; Ridley et al., 1994; Poulida et al., 1996; Ridley et al., 1996). The measurements identified enhanced NO mixing ratios of $0.1-0.8 \mathrm{nmol} \mathrm{mol}^{-1}$ in the sometimes $10-50 \mathrm{~km}$ wide anvil plumes, with local concentration "spikes" exceeding $4 \mathrm{nmol} \mathrm{mol}^{-1}$ (Luke et al., 1992). The large-scale enhancements within and outside thunderstorm anvils are more important in assessing $\mathrm{NO}_{\mathrm{x}}$ contributions from lightning than such short but high peak values.

In the 1990s, evidence for large $\mathrm{LNO}_{\mathrm{x}}$ contributions from lightning in midlatitude thunderstorms was provided by dedicated experiments in the USA and Europe (STERAO, LINOX, and EULINOX, see Table 3). These experiments performed measurements of the $\mathrm{NO}_{\mathrm{x}}$ concentrations directly in and near thunderstorms, including the outflow from the storm anvil, the composition of the boundary layer and the storm vicinity. The experimental setup combined airborne, radar and satellite observations of the cloud scales, structure and kinematics and ground-based and satellite-based lightning observations (Höller et al., 1999; Dye et al., 2000; Höller and Schumann, 2000). These experiments found highly variable $\mathrm{NO}_{\mathrm{x}}$ levels with many $\mathrm{NO}_{\mathrm{x}}$ peaks in the upper troposphere on small spatial scales near thunderstorms with lightning (Huntrieser et al., 1998). Mean $\mathrm{NO}_{\mathrm{x}}$ mixing ratios in the anvils $\left(0.8-2.2 \mathrm{nmol} \mathrm{mol}^{-1}\right)$ and the horizontal anvil scales were similar in these experiments (see Table 10). Simultaneous measurements of boundary layer air tracers like $\mathrm{CO}$ and $\mathrm{CO}_{2}$ indicated that the observed $\mathrm{NO}_{\mathrm{x}}$ only partly results from upward transported polluted air masses, see e.g., Fig. 14. Sometimes the anvils "mirror" the boundary layer in that the mixing ratio values of these tracers in the anvils are nearly as large as in the boundary layer. Analyses of these data show that on average about $70 \%$ of the $\mathrm{NO}_{\mathrm{x}}$ increase measured in the anvil region results from production by lightning and about $30 \%$ from $\mathrm{NO}_{\mathrm{x}}$ in the boundary layer (Huntrieser et al., 2002).

In parallel, $\mathrm{LNO}_{\mathrm{x}}$ contributions were identified at midlatitudes from airborne studies of other aspects of tropospheric chemistry. $\mathrm{LNO}_{\mathrm{x}}$ sources have been discriminated from stratospheric, aviation and surface $\mathrm{NO}_{\mathrm{x}}$ sources at midlatitudes over the North Atlantic during the NOXAR, POLINAT, SONEX and STREAM experiments in 1995-1997 (Brunner et al., 1998; Schumann et al., 2000; Thompson et al., 2000b; Lange et al., 2001) and the INTEX-A/ICARTT/ITOP experiments in 2004 (Fehsenfeld et al., 2006; Singh et al., 2006). Measurements over Canada, the North Atlantic and Europe, showed that convective clouds release $\mathrm{NO}_{\mathrm{x}}$ from surface pollution and lightning into the upper troposphere where it is carried over long distances and far over the Ocean. $\mathrm{NO}_{\mathrm{x}}$ 

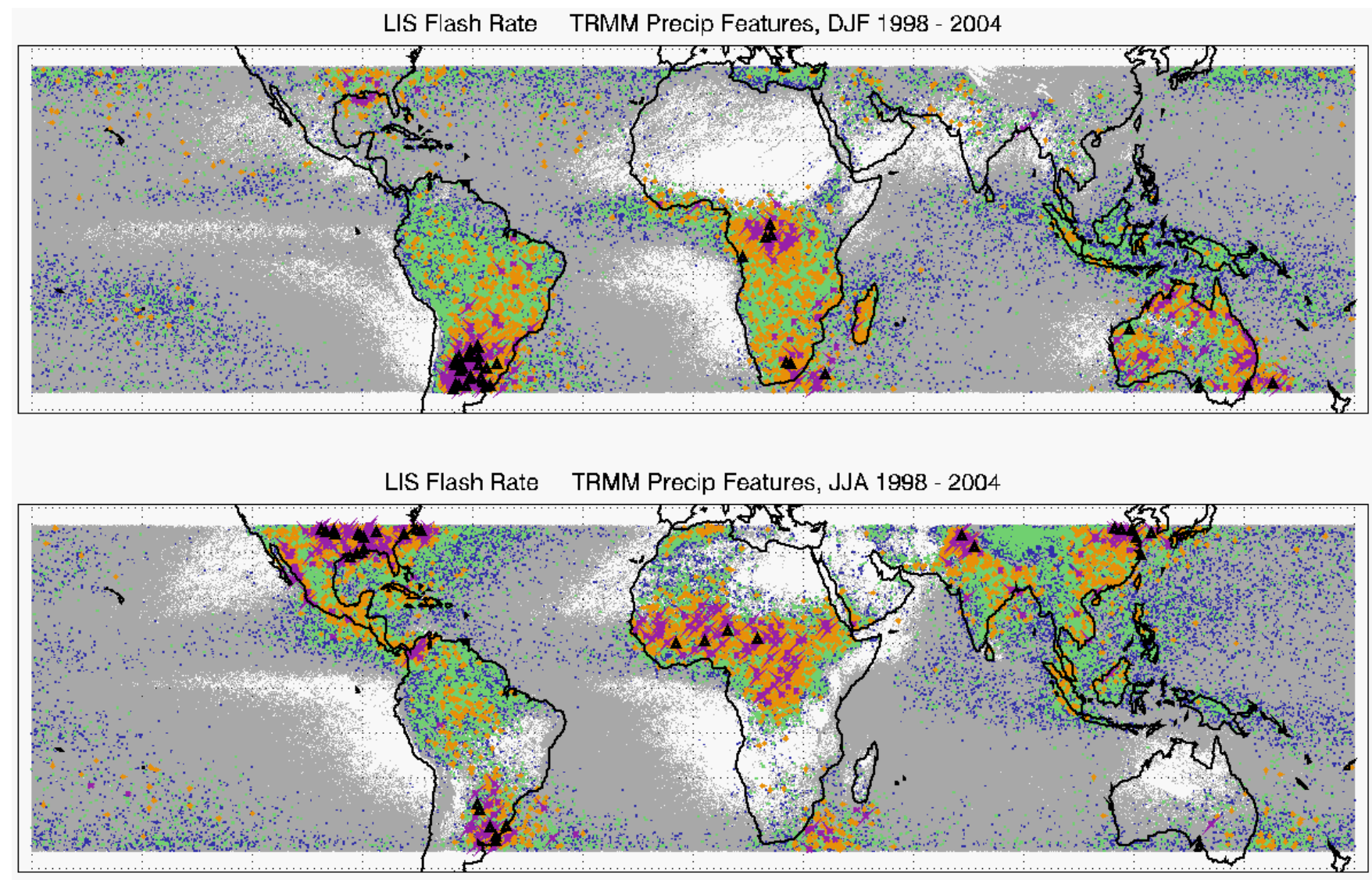

LIS Flash Rate TRMM Precip Features, March 1998 - Feb 2005

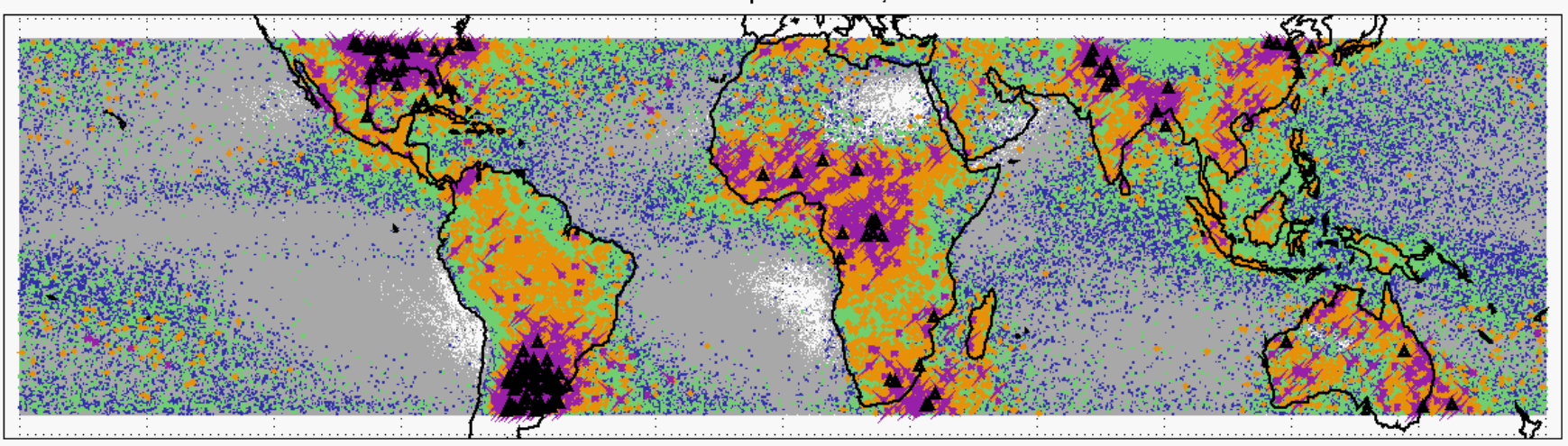

Fig. 12. Locations of precipitation features (PF) with high flash rates. A PF is a contiguous area greater than four pixels in size $\left(>75 \mathrm{~km}^{2}\right)$ with rain identified by the TRMM precipitation radar. The coloured symbols represent different categories of flash rates as in Cecil et al. (2005). Black triangles mark the top $0.001 \%$ of the 13.2 million precipitation features with flash rates between 310 and 1389 min $^{-1}$. Bottom all months in March 1998-February 2005, middle same for June, July, August, top for December, January, February only (from Cecil, 2005). Note that the satellite samples the high latitudes in the sub-tropics more often than the tropical ones.

enhancements between 0.5 and $4.0 \mathrm{nmol} \mathrm{mol}^{-1}$ were observed in these experiments (Crawford et al., 2000; Jeker et al., 2000; Schumann et al., 2000; Brunner et al., 2001; Lange et al., 2001). During the first POLINAT project in 1995, simultaneous measurements of $\mathrm{NO}, \mathrm{CO}_{2}, \mathrm{O}_{3}, \mathrm{H}_{2} \mathrm{O}, \mathrm{HNO}_{3}$, and acetone over Southern Ireland at $9.5 \mathrm{~km}$ altitude on 1
July showed NO increases of up to $0.6 \mathrm{nmol} \mathrm{mol}^{-1}$ in three 27 to $90 \mathrm{~km}$ wide flight segments correlated with increases in $\mathrm{HNO}_{3}$ and $\mathrm{H}_{2} \mathrm{O}$, but slight decreases in acetone and $\mathrm{O}_{3}$. Using $\mathrm{CO}_{2}$ and trajectory analysis, these events were related to $\mathrm{LNO}_{\mathrm{x}}$ produced in a large thunderstorm at about $8.7 \mathrm{~km}$ altitude about $20 \mathrm{~h}$ earlier, observed in satellite pictures over 


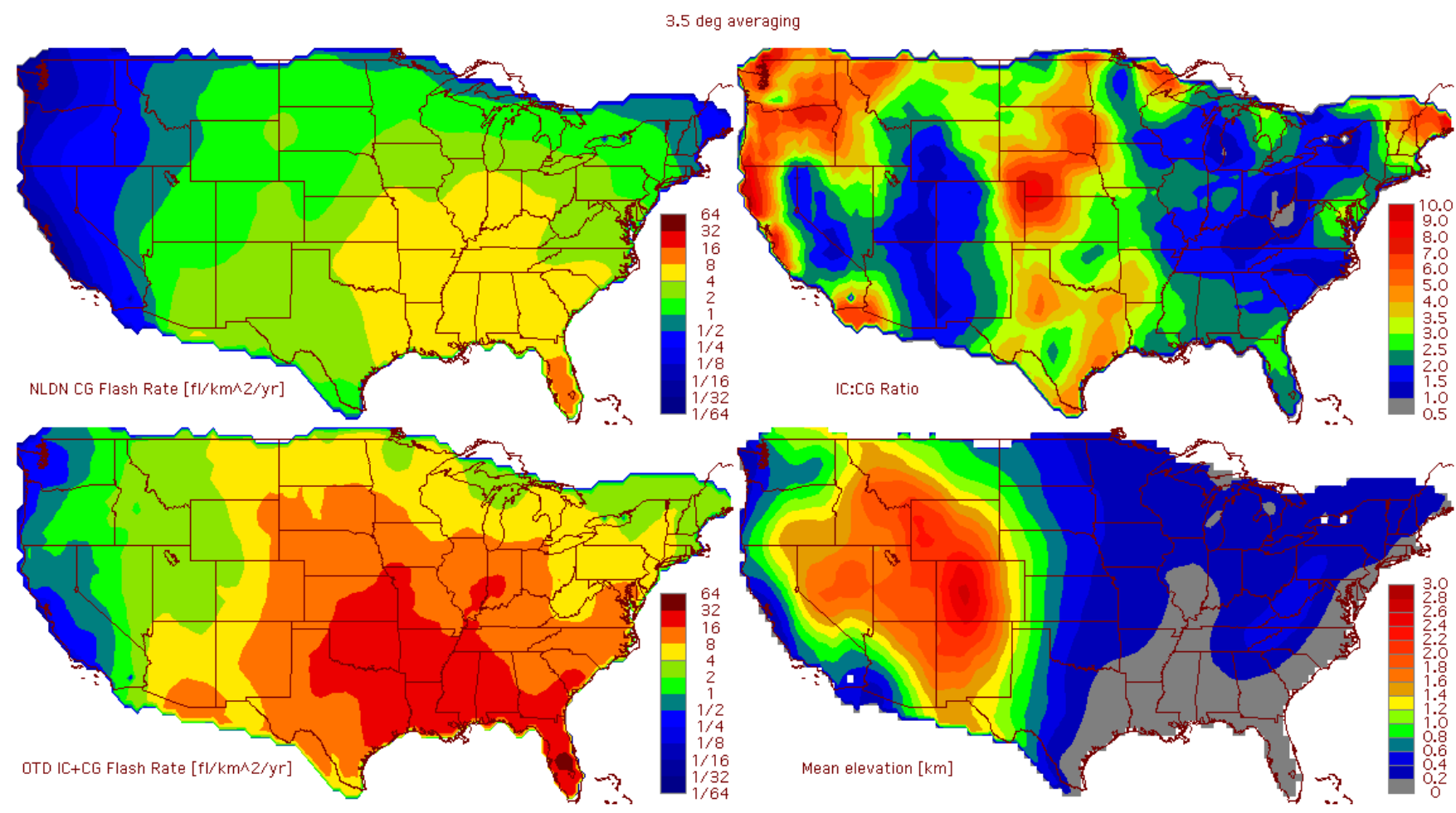

Fig. 13. CG (top left) and total (bottom left) flash rates derived from ground-based (NLDN) and satellite-based (OTD) lightning observations over the USA, together with the IC/CG ratio (top right) and the ground elevation (bottom right) (Boccippio et al., 2001).

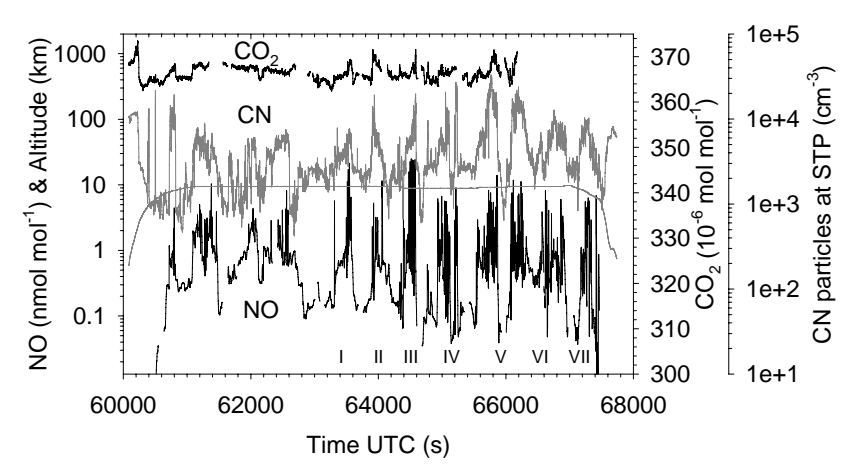

Fig. 14. Mixing ratios of $\mathrm{NO}$ and $\mathrm{CO}_{2}$ and particle concentration (CN) versus time during a flight over Southern Germany, 21 July 1998 (project EULINOX) (Huntrieser et al., 2002). More than 100 NO spikes were observed. An isolated thunderstorm was penetrated 7 times after $63500 \mathrm{~s}$ which is clearly visible in NO (labelled I-VII).

Northern Spain on the afternoon the day before (Huntrieser et al., 1996). Jeker et al. (2000) used air mass back trajectories, satellite infrared images and lightning observations from the NLDN network and the OTD satellite to analyse the origin of wide plumes with strongly enhanced $\mathrm{NO}_{\mathrm{x}}$ concentrations measured onboard a B-747 on flights between Zürich and the USA in 1997 during NOXAR/POLINAT-2. High NO concentrations were measured in plumes of marine thunderstorms with small contributions from continental surface emissions. $\mathrm{NO}_{\mathrm{x}}$ concentrations exceeding $3 \mathrm{nmol} \mathrm{mol}^{-1}$ were found in a plume of $300 \mathrm{~km}$ in width originating from lightning activity triggered over the warm Gulf Stream in November; and $\mathrm{NO}_{\mathrm{x}}$ concentrations up to $0.8 \mathrm{nmol} \mathrm{mol}^{-1}$ in a plume of about $1000 \mathrm{~km}$ in width was found in air originating from a marine thunderstorm over the Eastern Atlantic in August. The strong correlation with lightning events suggests that most of the measured $\mathrm{NO}_{\mathrm{x}}$ in these plumes originated from lightning (Brunner et al., 1998, 2001), in agreement with POLINAT and POLINAT-2 (Schumann et al., 2000) and SONEX results (Thompson et al., 1999; Crawford et al., 2000; Koike et al., 2000). In the recent INTEXA/ICARTT mission during 1 July-15 August 2004, i.e. during a period with strong convective and lightning activity, the composition of the upper troposphere over North America and the Atlantic was found to be significantly perturbed by influences from surface pollution and lightning (Singh et al., 2007). The $\mathrm{LNO}_{\mathrm{x}}$ source was found to be far larger than anticipated based on previous measurements over the USA (Jaeglé et al., 1998) and model simulations (Cooper et al., 2006; Martin et al., 2006; Hudman et al., 2007).

$\mathrm{LNO}_{\mathrm{x}}$ contributions to the tropical troposphere have been identified mainly by correlations with other trace gases. Carroll and Thompson (1995) and Bradshaw et al. (2000) reviewed the results from the GTE program including the projects ABLE 2A, PEM-West A and B, and PEM-Tropics 
A (see Table 3). No clear $\mathrm{LNO}_{\mathrm{x}}$ signal was observed during the ABLE 2A mission over the Amazon Basin during the dry season in August. The NO mixing ratios reached up to $0.2 \mathrm{nmol} \mathrm{mol}^{-1}$ in regions of electrically active clouds at altitudes up to $5 \mathrm{~km}$ (Torres et al., 1988; Pickering et al., 1991). However, clear signals of lightning-generated $\mathrm{NO}_{\mathrm{x}}$ were detected during a flight at $9-12 \mathrm{~km}$ altitude in the TRACE-A experiment in the Brazilian cerrado (savanna-type environment) at $6-12^{\circ} \mathrm{S}, 45-49^{\circ} \mathrm{W}$ during one day (27 September 1992) at the end of the dry season (Pickering et al., 1996). The region was covered with deep convective clouds reaching at least up to $16 \mathrm{~km}$ altitude $8-9 \mathrm{~h}$ before the flight. The convective system occurred over regions of biomass burning activity. From the $\mathrm{NO}_{\mathrm{x}} / \mathrm{CO}$ ratio, about $40 \%$ of the $\mathrm{NO}_{\mathrm{x}}$ at the $9.6 \mathrm{~km}$ level and $32 \%$ at $11.3 \mathrm{~km}$ were attributed to lightning (Pickering et al., 1996). In the outflow to the South Atlantic, upper tropospheric NO plumes at horizontal scales of $100-1000 \mathrm{~km}$ were observed as resulting from deep convection over Northern Brazil (partly from MCS) transporting $\mathrm{NO}_{\mathrm{x}}$ emissions from both biomass burning and $\mathrm{LNO}_{\mathrm{x}}$ (Smyth et al., 1996b). From the ethyne $\left(\mathrm{C}_{2} \mathrm{H}_{4}\right)$ to $\mathrm{CO}$ ratio, Smyth et al. (1996b) (see also Bradshaw et al., 2000) deduced that enhanced $\mathrm{NO}_{\mathrm{x}}$ values in the upper troposphere in the Southern Atlantic Basin are not predominantly the direct result of biomass burning emissions. Instead, a large share of the $\mathrm{NO}_{\mathrm{x}}$ originates from recycling of its oxidation products (mainly from $\mathrm{HNO}_{3}$ ) (Davis et al., 1996; Jacob et al., 1996). As a consequence of recycling, the effective lifetime of $\mathrm{NO}_{\mathrm{x}}$ is larger than its oxidation lifetime, increasing the $\mathrm{O}_{3}$ production rate. Moreover, Smyth et al. (1996b) assess that lightning is responsible for at least $50 \%$ of the initial (not recycled) $\mathrm{NO}_{\mathrm{x}}$ in the upper troposphere. The magnitude of the regional lightning source is estimated as $0.3 \mathrm{Tg} \mathrm{a}^{-1}$, implying a global $\mathrm{LNO}_{\mathrm{x}}$ source of "several" $\mathrm{Tg} \mathrm{a}{ }^{-1}$. Davis et al. (1996) differentiate between continental surface sources and high altitude $\mathrm{NO}_{\mathrm{x}}$ sources (lightning, aviation, stratospheric sources or recycled $\mathrm{NO}_{\mathrm{y}}$ ) using the $\mathrm{NO}_{\mathrm{x}} / \mathrm{C}_{3} \mathrm{H}_{8}$ (propene) ratio and attribute the major fraction (possibly $71 \%$ ) of $\mathrm{NO}_{\mathrm{x}}$ in the upper troposphere during PEM West A to lightning. The conclusions were limited by uncertainties in measured $\mathrm{NO}_{\mathrm{y}}$ and $\mathrm{HNO}_{3}$ and the models used.

Enhanced $\mathrm{NO}_{\mathrm{x}}$ concentrations from convective outflow from tropical continents can be identified from measurements during individual flights across the tropical belt over continents or along the continental shore during the European projects STRATOZ III, TROPOZ II, and INCA (see Table 3). The early experiments focused on periods with enhanced biomass burning (Jonquieres and Marenco, 1998). $\mathrm{LNO}_{\mathrm{x}}$ superimposed on biomass burning contributions was identified from measurements near the west coast of South America between $4-6^{\circ} \mathrm{S}$ at about $11.5 \mathrm{~km}$ altitude during the INCA experiment in March and April 2000 (Baehr et al., 2003). High peak values of $\mathrm{NO}$ and $\mathrm{NO}_{\mathrm{y}}$ mixing ratios (up to 1.3 and $2.3 \mathrm{nmol} \mathrm{mol}^{-1}$ ) and high $\mathrm{NO}_{\mathrm{x}} / \mathrm{NO}_{\mathrm{y}}$ ratios $(0.46$ in the peaks) indicate relative fresh $\mathrm{NO}_{\mathrm{x}}$ sources. For com- parison, similar peaks of fresh $\mathrm{NO}_{\mathrm{x}}$ over the Pacific ocean between $4^{\circ}$ and $10^{\circ} \mathrm{S}$ remain below $0.3 \mathrm{nmol} \mathrm{mol}^{-1}$, with a few scattered peaks reaching higher (Kawakami et al., 1997; Kondo et al., 2003b). Air mass back trajectories and high $\mathrm{CO}$ concentrations indicate that the air masses measured in the upper tropical troposphere during INCA originate from the Amazon basin uplifted by deep convection (Schumann et al., 2004a). A combination of trajectories, infrared satellite images, brightness temperature analysis, and OTD lightning flash data shows that all of the air masses measured along the flight path were influenced by deep convection during the previous 3 days. The air masses with high $\mathrm{NO}$ and $\mathrm{NO}_{\mathrm{y}}$ originate from convective events over the western Amazon (about $5^{\circ} \mathrm{S}, 71^{\circ} \mathrm{W}$ ) $7-12 \mathrm{~h}$ before the time of the measurements. The OTD data show lightning activity in the same region. The high $\mathrm{NO} / \mathrm{NO}_{\mathrm{y}}$ ratio is caused by fresh lightninginduced NO. Compact CO-NO $\mathrm{NO}_{\mathrm{y}}$ correlations were found in air masses of the same age relative to the origin from convection. Because of different lifetimes, the $\mathrm{NO}_{\mathrm{y}}$ to $\mathrm{CO}$ ratio decreases from 0.016 to 0.008 with plume age increasing from about $1-6 \mathrm{~h}$ to $13-18 \mathrm{~h}$.

Convective outflow can also be seen in the many flights where measurements were performed with instrumented containers onboard airliners in the projects MOZAIC and CARIBIC, including flights towards North America, Asia, South Africa, and South America (see Table 3). MOZAIC has been performing extensive $\mathrm{NO}_{\mathrm{y}}$ and $\mathrm{NO}$ measurements since April 2001 (Pätz et al., 2006), CARIBIC performed NO and $\mathrm{NO}_{\mathrm{y}}$ measurement flights in 2002 and has been performing again since 2004 (Brenninkmeijer et al., 2007).

In-situ observations targeting $\mathrm{LNO}_{\mathrm{x}}$ from tropical and subtropical thunderstorms over continents with simultaneous lightning observations have been performed since 2000 (see Table 3). $\mathrm{LNO}_{\mathrm{x}}$ contributions were found within large air masses during two flights of the project BIBLE near Darwin, Australia, in December 2000 (Koike et al., 2007). $\mathrm{NO}_{\mathrm{x}}$ enhancements up to 1 and $1.6 \mathrm{nmol} \mathrm{mol}^{-1}$ were observed at altitudes between 11.5 and $14 \mathrm{~km}$. The region with $\mathrm{NO}_{\mathrm{x}}$ mixing ratio larger $0.1 \mathrm{nmol} \mathrm{mol}^{-1}$ extended over $620 \times 140$ and $400 \times 170 \mathrm{~km}$ (wind direction $\times$ perpendicular direction) in the two flights, respectively. Intensive lightning events took place upstream from the measurement area $10-14 \mathrm{~h}$ prior to the measurements. From the data, a global $\mathrm{LNO}_{\mathrm{x}}$ source rate of about $1-17 \mathrm{Tg} \mathrm{a}^{-1}$ was estimated.

Airborne in-situ observations near sub-tropical (possibly also tropical) thunderstorms have been obtained during CRYSTAL-FACE in Florida (see Sect. 3.1.3). Compared to measurements elsewhere, these measurements show relatively high mean NO abundances (typically 1.2, up to $4 \mathrm{nmol} \mathrm{mol}^{-1}$ ) in wide anvils (Ridley et al., 2004).

Extensive airborne in-situ observations near sub-tropical and tropical thunderstorms were obtained during the TROCCINOX experiments, which were performed over the State of São Paulo and surroundings in Brazil (10-28 $8^{\circ}$ and $38-55^{\circ} \mathrm{W}$ ) during the wet season in 2004 and 2005, when 

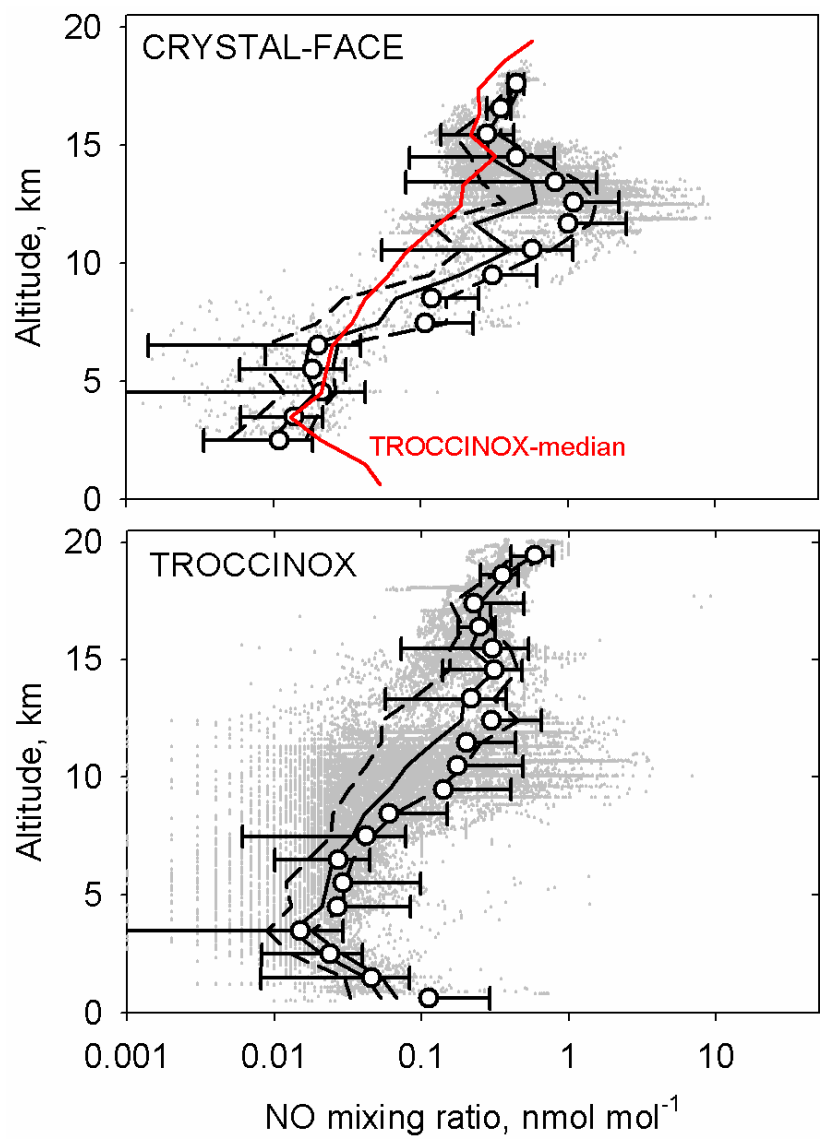

Fig. 15. Nitrogen oxide mixing ratio data (grey) with median (full curve) and $25 \%$ (short dashed) and $75 \%$ percentiles (long dashed) and mean values with standard deviation (circles with error bars) from CRYSTAL-FACE $\left(24-27^{\circ} \mathrm{N}, 77-86^{\circ} \mathrm{W}\right.$, July 2002 ; top, data provided by B. Ridley) and TROCCINOX (data from $0-28^{\circ} \mathrm{S}, 38$ $55^{\circ} \mathrm{W}$, February-March 2004 and February 2005, bottom, data provided by $\mathrm{H}$. Schlager). Every 10th data point with $1 \mathrm{~s}$ temporal resolution is indicated by a grey dot. The red curve in the top panel shows the median TROCCINOX result for easier comparison.

biomass burning contributions were small for most of the time. The area of operation was located along the South Atlantic convergence zone, a transition zone between tropical and subtropical air masses. The observations included also measurements in air masses coming from MCS. Airborne measurements in the troposphere and the lower stratosphere, together with satellite, radar and lightning observations provided a comprehensive set of cloud, lightning and trace species data in clear air and in clouds, including thunderstorm anvils (Schumann et al., 2004a, b; Huntrieser et al., 2007). Lightning observations were performed with LINET (Betz et al., 2004; Schmidt et al., 2005), see Fig. 8, as discussed before.

Both CRYSTAL-FACE and TROCCINOX provide data on NO mixing ratios inside and near convective clouds with high NO peaks, see Fig. 15. Simultaneous CO data show little cor- relation with $\mathrm{NO}_{\mathrm{x}}$; hence, the $\mathrm{NO}_{\mathrm{x}}$ peaks are not caused by upward transport of polluted air masses from the boundary layer but originate from lightning. TROCCINOX includes measurements in air masses with and without contributions from deep convection whereas the CRYSTAL-FACE data have been taken preferably close to convective clouds. The median $\mathrm{NO}_{\mathrm{x}}$ values at about 9-12 km altitude during TROCCINOX are within $0.3-0.6 \mathrm{nmol} \mathrm{mol}^{-1}$; higher median values are observed in the anvil outflows of the sub-tropical and tropical thunderstorms $\left(0.5-1.5 \mathrm{nmol} \mathrm{mol}^{-1}\right)$. The NO median value concentrations over Florida $\left(1-4 \mathrm{nmol} \mathrm{mol}^{-1}\right)$ are higher than those from the Brazilian thunderstorms and related to wider regions of $\mathrm{NO}_{\mathrm{x}}$ enhancement. There is no indication that tropical thunderstorms produce more $\mathrm{LNO}_{\mathrm{x}}$ per stroke or storm than midlatitude storms, in fact the opposite may be the case (Huntrieser et al., 2007).

These and earlier airborne experiments found sometimes very large, short-duration local NO spikes, see Table 10. However, one cannot exclude that these spikes are caused by local (hot or cold) discharges occurring on the aircraft fuselage or air sampling system (see also Sect. 2.5). In fact, such discharges cause electric sparks as observed with the LMA lightning detection system (Thomas et al., 2004): Aircraft induce typically $10^{2}-10^{4} \mathrm{~s}^{-1}$ small sparks with a source power of $2-5 \mathrm{~W}$ by collision charging from the planes as they fly through ice clouds. The very high NO peak measured during CRYSTAL-FACE was convincingly identified to be caused by cold discharges (Ridley et al., 2006). The highest NO peak $\left(25 \mathrm{nmol} \mathrm{mol}^{-1}\right)$ obtained in EULINOX may be real because it was measured immediately after a flash hit the aircraft (Huntrieser et al., 2002);

Ground-based measurements of $\mathrm{NO}_{2}$ slant columns during the passage of thunderstorms have been presented in a few studies. Reported $\mathrm{NO}_{2}$ column peak values near lightning flashes are 2.5 (Noxon, 1976, 1978), 1-3 (Jadhav et al., 1996), 7 (Winterrath et al., 1999), 12 (Langford et al., 2004), and 6-9 (Fraser et al., 2007), in units of $10^{17} \mathrm{NO}_{2}$ molecules $\mathrm{cm}^{-2}$. These peak values are far larger than typical background values (Langford et al., 2004; Wenig et al., 2004). Some of the data may overestimate the $\mathrm{NO}_{2}$ column due to effective path length enhancements by photon diffusion in optically thick clouds or multiple reflections between clouds (Pfeilsticker et al., 1998; Meena et al., 2004). The last three studies corrected for such enhancements using simultaneous measurements of gases such as $\mathrm{O}_{2}$ and $\mathrm{O}_{4}$, with known vertical profiles (Erle et al., 1995).

In spite of the difficulties explained before, $\mathrm{LNO}_{\mathrm{x}}$ contributions may be identified in satellite $\mathrm{NO}_{2}$ column data in regions and at times where the $\mathrm{LNO}_{\mathrm{x}}$ contribution to $\mathrm{NO}_{2}$ columns is large. A case study of tropospheric $\mathrm{NO}_{2}$ above Africa in fall 1997 revealed signatures from lightning and from anthropogenic and biomass burning sources (Richter and Burrows, 2002). From a correlation between GOME $\mathrm{NO}_{2}$, LIS lightning flash distributions, and satellite data indicating $\mathrm{O}_{3}$ increases, lightning over Southern 


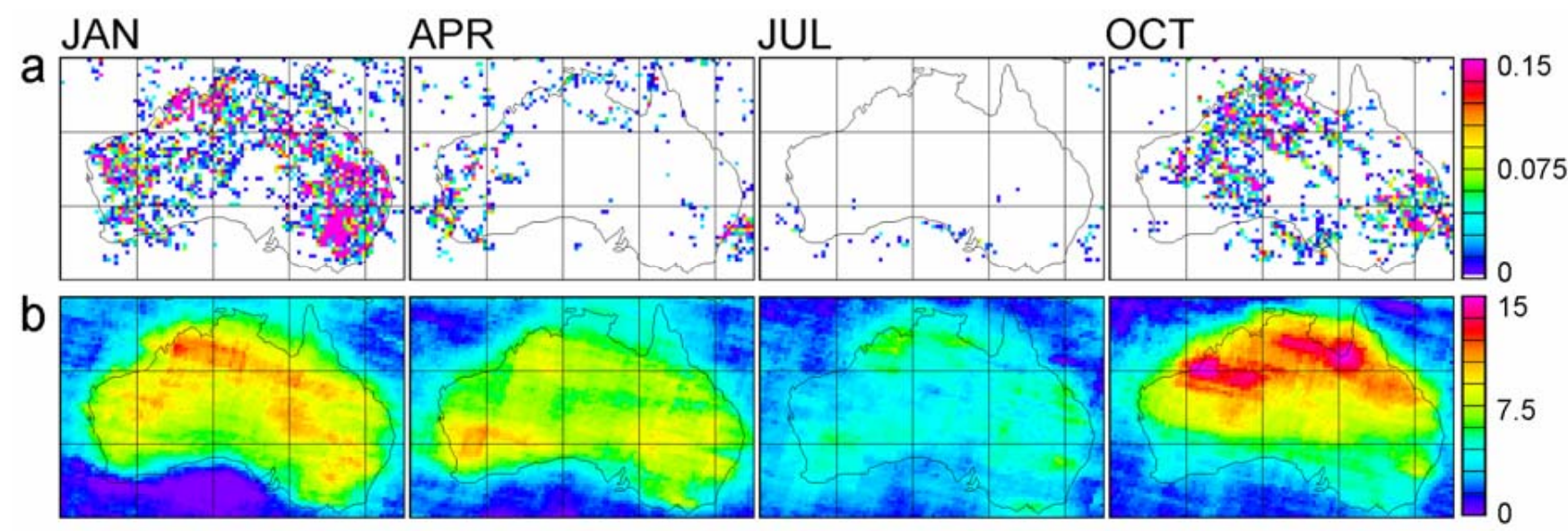

Fig. 16. Monthly mean LIS flash counts (upper row, flashes per day and km) and GOME tropospheric $\mathrm{NO}_{2}$ column (lower row, $10^{14}$ molecules $\mathrm{cm}^{-2}$; corrected for air mass factors) in Australia for several months in 1999 as discussed in Beirle et al. (2004b); figure from Beirle (2004), with kind permission of Elsevier.

Africa has been identified as a source of mid-troposphere $\mathrm{NO}_{\mathrm{x}}$ and $\mathrm{O}_{3}$ in addition to biomass burning (Edwards et al., 2003). Unusually large tropospheric GOME $\mathrm{NO}_{2}$ columns $\left(\leq 55 \times 10^{14}\right.$ molecules $\left.\mathrm{cm}^{-2}\right)$ observed during a severe weather event over the western Mediterranean in November 2001 were interpreted as $\mathrm{LNO}_{\mathrm{x}}$ transport from coastal regions with high lightning activity (Thomas et al., 2003). Lightning enhancements of $\mathrm{NO}_{2}$ have been identified over the North American continent and the western North Atlantic during a few days with convective or cyclogenesis events in April 2000 from GOME $\mathrm{NO}_{2}$ and regional model results (Choi et al., 2005). GOME data over Australia $\left(\leq 5.5 \times 10^{14} \mathrm{~cm}^{-2}\right)$, see Fig. 16 (Beirle, 2004), the Gulf of Mexico $\left(\leq 40 \times 10^{14} \mathrm{~cm}^{-2}\right)$, and several tropical regions $\left(7-10 \times 10^{14} \mathrm{~cm}^{-2}\right)$, have been related to observed lightning frequencies and model results to quantify $\mathrm{NO}_{\mathrm{x}}$ emissions per flash (Beirle et al., 2004b, 2006; Boersma et al., 2005). Broad lightning enhanced $\mathrm{NO}_{2}$ columns of about 2-6 $\times 10^{14}$ molecules $\mathrm{NO}_{2} \mathrm{~cm}^{-2}$ were identified over the tropical Atlantic and Africa from SCIAMACHY data with the help of model results (Martin et al., 2007). Recently, Sioris et al. (2007) analysed limb scattered radiation in the $280-810 \mathrm{~nm}$ range in the upper troposphere measured with OSIRIS. They identified $\mathrm{NO}_{2}$ enhancements of up to $0.92 \mathrm{nmol} \mathrm{mol}^{-1}$. The peaks were related to $\mathrm{LNO}_{\mathrm{x}}$ sources using model results and LIS observations; the $\mathrm{NO}_{2}$ from lightning was found to occur generally at 12 to $13 \mathrm{~km}$ more frequently than at 10 to $11 \mathrm{~km}$. Similar $\mathrm{NO}_{2}$ peaks were observed by balloon-borne remote sensing during HIBISCUS (Pommereau et al., 2007): The observed $\mathrm{NO}_{2}$ concentrations reached up to $0.5 \mathrm{nmol} \mathrm{mol}^{-1}$ at about $12-14 \mathrm{~km}$ in the upper troposphere over South America and Africa; smaller concentrations of $0.1 \mathrm{nmol} \mathrm{mol}^{-1}$ or less were found over the South Pacific Convergence Zone and Australia, although deep convection is also frequent there.

\subsection{Other trace species from lightning}

Lightning and cold discharges may induce some further gas species, including $\mathrm{O}_{3}, \mathrm{~N}_{2} \mathrm{O}, \mathrm{HNO}_{2}, \mathrm{HNO}_{3}, \mathrm{H}_{2} \mathrm{O}_{2}, \mathrm{HO}_{2}$, and $\mathrm{CO}$, and small particles into the atmosphere (Levine, 1981; Levine and Shaw Jr., 1983; Hill et al., 1984; Bhetanabhotla et al., 1985; Chameides, 1986; Zuo and Deng, 1999). Trace gas production by sprites (with estimated global rates of $0.5-$ $33 \mathrm{~min}^{-1}$ (Sato and Fukunishi, 2003; Ignaccolo et al., 2006)) and similar transient luminescent events is expected to have local importance in the middle atmosphere but small global significance (Mishin, 1997; Rakov and Uman, 2003; Hiraki et al., 2004; Füllekrug et al., 2006). Table 11 compiles published estimates of the formation of various trace gases besides $\mathrm{NO}_{\mathrm{x}}$. The various emission estimates are based on laboratory work and theoretical considerations without systematic verifications. Some of the papers report opposing views.

The fact that electrical discharges produce $\mathrm{O}_{3}$ is well known. Martinus van Marum noted in 1785 "the odour of electrical matter," and determined that air and oxygen subjected to electrical discharges tarnished mercury, but he did not identify the gas as an allotrope of oxygen. During electrolysis experiment in 1839, Christian Schönbein attributed a similar odour to a substance which he named "ozone," from the Greek ozien, "to smell" (Rubin, 2001). Today, lightning is known to produce very little $\mathrm{O}_{3}\left(\right.$ and $\mathrm{N}_{2} \mathrm{O}$ ). In fact, ozone may get destroyed in the hot flash channel, but these gases may be formed from cold discharges and in the cold corona around hot flashes (Buettner et al., 1962; Donohoe et al., 1977; Griffing, 1977; Levine, 1981; Hill et al., 1988; Franzblau, 1991). In contrast, $\mathrm{NO}_{\mathrm{x}}$ is produced mainly by the hot lightning strokes, not corona discharges (Noxon, 1978; Martinez and Brandvold, 1996; Coppens et al., 1998). Except for $\mathrm{N}_{2} \mathrm{O}$ in one study (Levine and Shaw Jr., 1983), airborne measurements in thunderstorm anvils generally show 
Table 11. Global lightning production rates for trace species.

\begin{tabular}{|c|c|c|c|c|}
\hline Species & Value reported in the reference & $\begin{array}{l}\text { Global emission rate, } \\
\mathrm{Tg} \mathrm{a}^{-1} \text { (2) }\end{array}$ & Reference & Method \\
\hline \multirow[t]{5}{*}{$\mathrm{N}_{2} \mathrm{O}$} & $8 \times 10^{24}$ molecules per flash & 0.8 & Griffing (1977) & Theory \\
\hline & $1 \times 10^{-4} \mathrm{~mol} \mathrm{C}^{-1}$ & $1.5 \times 10^{-6}$ & Donohoe et al. (1977) & Laboratory \\
\hline & $1.5 \times 10^{13}$ molecules $\mathrm{J}^{-1}$ & $500 \times 10^{-6}$ & Hill et al. (1984) & Theory \\
\hline & $220 \times 10^{-6} \mathrm{Tg} \mathrm{a}^{-1(1)}$ & $100 \times 10^{-6}$ & Bhetanabhotla et al. (1985) & Theory \\
\hline & $(3-13) \times 10^{12}$ molecules $\mathrm{J}^{-1}$ & $(100-400) \times 10^{-6}$ & Chameides (1986) & Theory \\
\hline $\mathrm{H}_{2} \mathrm{O}_{2}$ & $320 \times 10^{-6} \mathrm{Tg} \mathrm{a}^{-1(1)}$ & $140 \times 10^{-6}$ & Bhetanabhotla et al. (1985) & Theory \\
\hline $\mathrm{HO}_{2}$ & $320 \times 10^{-6} \mathrm{Tg} \mathrm{a}^{-1(1)}$ & $140 \times 10^{-6}$ & Bhetanabhotla et al. (1985) & Theory \\
\hline \multirow[t]{2}{*}{$\mathrm{CO}$} & $1 \times 10^{14}$ molecules $^{-1}$ & 0.04 & Levine et al. (1979) & Laboratory \\
\hline & $(1-50) \times 10^{13}$ molecules $\mathrm{J}^{-1}$, & $0.004-0.2$ & Chameides (1979b, 1986) & Laboratory \\
\hline \multirow[t]{3}{*}{$\mathrm{O}_{3}$} & $1.2 \times 10^{22}$ molecules $\mathrm{C}^{-1}$ & 0.03 & Paetzold and Regener (1957) & Cold discharge estimate \\
\hline & $2 \times 10^{17}$ molecules $\mathrm{J}^{-1}(0.03$ per $\mathrm{eV})$ & 150 & Kroening and Ney (1962); Buettner et al. (1962) & Laboratory \\
\hline & $(5-7) \times 10^{16}$ molecules $\mathrm{J}^{-1}$ in negative streamers & 40 & Cooray and Rahman (2005) & Laboratory \\
\hline
\end{tabular}

(1) Based on a global flash rate of $100 \mathrm{~s}^{-1}$; including both hot channels and corona productions (Bhetanabhotla et al., 1985).

(2) Assuming a discharge energy of 6.7 GJ per flash (Price et al., 1997b), a flash rate of $44 \mathrm{~s}^{-1}$ (Christian et al., 2003), a global discharge current of $1 \mathrm{kA}$ (Donohoe et al., 1977) (the total air-Earth current is about 1.8 kA (Harrison, 2004)), and the molar mass of the respective species.

no lightning contributions to trace gases, in particular no enhancements of $\mathrm{O}_{3}$ and $\mathrm{CO}$ (Dickerson et al., 1987; Luke et al., 1992; Ridley et al., 1994, 2006; Hauf et al., 1995; Huntrieser et al., 1998; Jeker et al., 2000). Nevertheless, a few studies reported partially large $\mathrm{O}_{3}$ increases exceeding several $100 \mathrm{nmol} \mathrm{mol}^{-1}$ (Sisterson and Liaw, 1990; Zahn et al., 2002; Güsten et al., 2003) near thunderstorms using various observation methods (Dobson et al., 1946; Orville, 1967; Shantla and Moore, 1972; Clarke and Griffing, 1985; Jadhav et al., 1996; Borra et al., 1997; Suhre et al., 1997; Randriambelo et al., 1999; Winterrath et al., 1999). However, ground-based spectroscopy of visible light absorption by $\mathrm{O}_{3}$ may suffer from multiple scattering in the clouds (Platt et al., 1997); in-situ measurements of $\mathrm{O}_{3}$ by ultraviolet absorption near deep convective events with high water vapour concentration changes are prone to an instrument interference with water vapour (Meyer et al., 1991; Huntrieser et al., 2007); and $\mathrm{O}_{3}$ (also $\mathrm{NO}$ and $\mathrm{NO}_{2}$ ) may be formed by local corona discharges at the instrument's inlet in intense electrical fields inside thunderstorms (Zahn et al., 2002; Ridley et al., 2006). Also the "extremely high $\mathrm{O}_{3}$ peaks near ground" reported by Attmannspacher and Hartmannsgruber (1973) are likely caused by electrical discharges at the heated inlets of the instruments (P. Winkler, personal communication, 2006). The very high $\mathrm{N}_{2} \mathrm{O}$ peak concentrations reported in one early study (Levine and Shaw Jr., 1983) would imply unrealistically large global $\mathrm{N}_{2} \mathrm{O}$ emission rates (own calculation).
The global emission rate estimates in Table 11 are computed for an assumed discharge energy of $6.7 \mathrm{GJ}$ per flash (Price et al., 1997b); other studies suggest at least ten times smaller values (Borucki and Chameides, 1984; Jayakumar et al., 2006). Nevertheless, flashes contribute only small fractions to the global budgets of the individual species. The total tropospheric chemical production rate of $\mathrm{O}_{3}$ mass is of the order of 2500-4500 $\mathrm{Tg} \mathrm{a}^{-1}$ (IPCC, 2001; Stevenson et al., 2006), the total amount of CO mass emitted from all sources at the Earth surface is of the order of $2800 \mathrm{Tg} \mathrm{a}^{-1}$ (Mueller and Stavrakou, 2005), and that of $\mathrm{N}_{2} \mathrm{O}$ is of the order of $20 \mathrm{Tg} \mathrm{a}^{-1}$ (Bouwman et al., 2002). The most recent estimates listed in Table 11 suggest lightning contributions to global sources of $\mathrm{O}_{3}, \mathrm{CO}$, and $\mathrm{N}_{2} \mathrm{O}$, of $40,0.2$, and $4 \times 10^{-4} \mathrm{Tg} \mathrm{a}^{-1}$, respectively. Hence, the relative lightning contributions may amount to an order of $2 \%, 0.01 \%$, and $0.002 \%$, for $\mathrm{O}_{3}, \mathrm{CO}$ and $\mathrm{N}_{2} \mathrm{O}$, respectively.

Condensation nuclei have been observed both in the laboratory and the atmosphere to be formed by flashes possibly due to nucleation of nitric acid (Peyrous and Lapeyre, 1982) or from sulphuric acid produced by oxidation of $\mathrm{SO}_{2}$ with $\mathrm{H}_{2} \mathrm{O}_{2}$ in the aqueous phase (Chameides, 1986). Thunderstorms may also contribute to ions and subsequent particle nucleation (Yu and Turco, 2001). High concentrations of $\mathrm{CN}$ (of unknown composition) have been measured in the outflow of thunderstorm anvils (Huntrieser et al., 2002), see Fig. 14. The concentration of condensation nuclei formed 

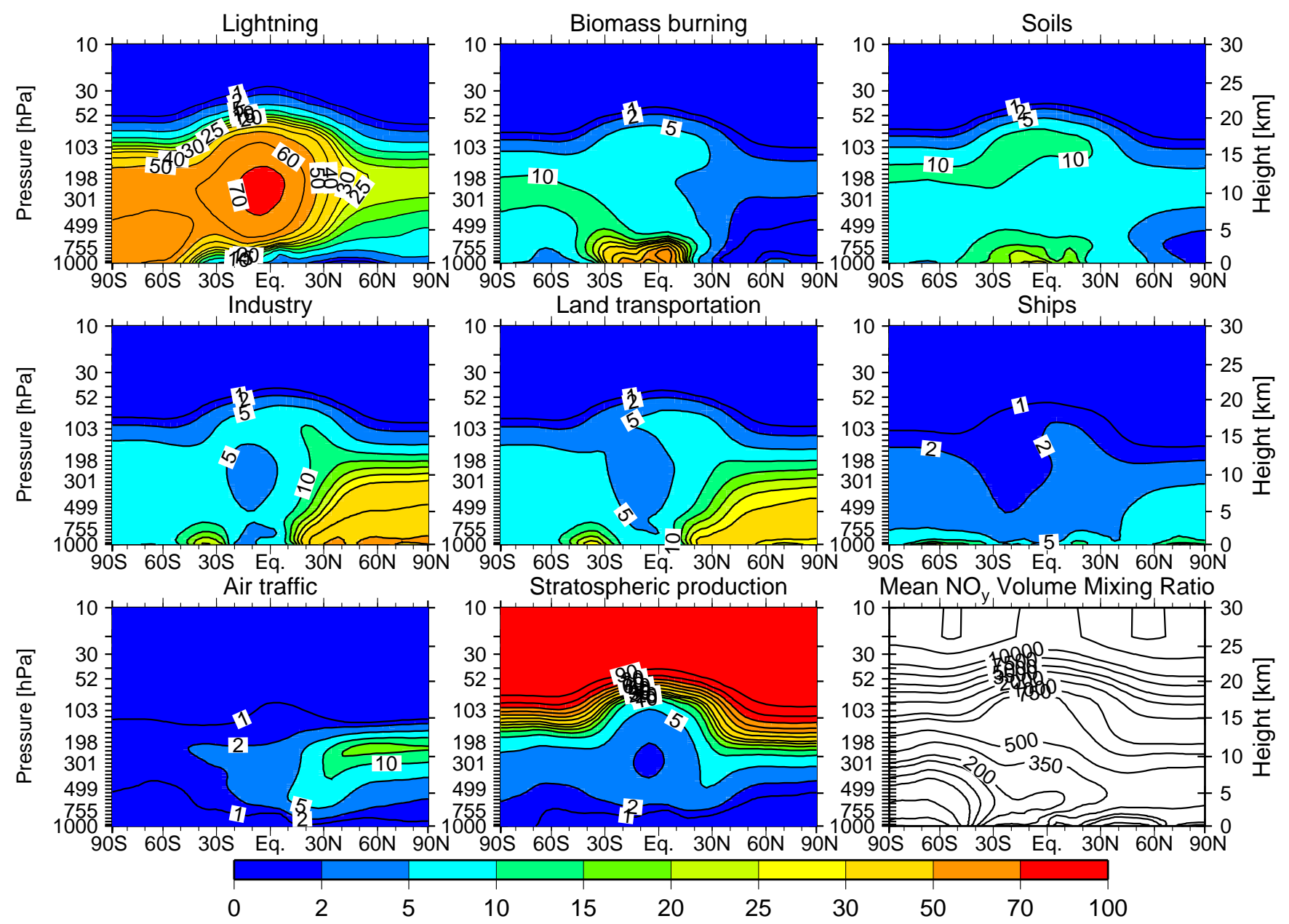

Fig. 17. Relative contributions $(\%)$ to the $\mathrm{NO}_{\mathrm{y}}$ budget from various sources as a function of latitude and pressure-altitude in the annual mean; figure from Grewe (2007), with kind permission of Elsevier.

in storm anvils decreases by coagulation with typical time scales of $4 \mathrm{~h}$; the concentration has been used as "chemical clock" for the age of air masses since convective outflow (Jaeglé et al., 1998). High particle concentrations may arise (possibly also without lightning), by homogeneous nucleation of sulphuric acid in the anvil after scavenging of most other aerosol mass (Clarke et al., 1999). A recent study suggests that most sulphuric acid will be washed out in anvils and the particles form from insoluble organic trace gases (Kulmala et al., 2006). The particle emissions are of relevance in regions with deep convection at midlatitudes and in the tropics (Wang et al., 2000; Minikin et al., 2003).

\subsection{Importance of $\mathrm{LNO}_{\mathrm{x}}$ for atmospheric chemistry}

Thunderstorms inject $\mathrm{NO}_{\mathrm{x}}$ mainly into the relatively clean upper troposphere. Locally within the cloud the concentrated NO reacts with ambient $\mathrm{O}_{3}$ to produce $\mathrm{NO}_{2}$ which reduces the $\mathrm{O}_{3}$ abundance accordingly. Mainly in the clear air outside the cloud, after dilution and at time scales of the order of hours to weeks, the increased $\mathrm{NO}_{\mathrm{x}}$ causes, as explained before, a photocatalytic production of $\mathrm{O}_{3}$ (Pickering et al., 1996; DeCaria et al., 2005). Part of the $\mathrm{NO}_{2}$ reacts with $\mathrm{OH}$ to $\mathrm{HNO}_{3}$ which may get washed out. In the upper troposphere the lifetime of $\mathrm{NO}_{\mathrm{x}}$ due to oxidation is of the order of several days, see Table 4. Some $\mathrm{LNO}_{\mathrm{x}}$ emissions remain in the atmosphere far longer: Part of the $\mathrm{LNO}_{\mathrm{x}}$ gets converted to PAN which may release $\mathrm{NO}_{\mathrm{x}}$ after subsidence into warmer regions far from its source region (Moxim et al., 1996; Schultz et al., 1999; Hudman et al., 2004). Some $\mathrm{LNO}_{\mathrm{x}}$ gets transported from the upper tropical troposphere, by isentropic transport at altitudes of around $100 \mathrm{hPa}$, into the lower-most stratosphere at midlatitudes (Grewe et al., 2004) where it may add to $\mathrm{NO}_{\mathrm{x}}$ from aviation and from stratospheric sources. The $\mathrm{LNO}_{\mathrm{x}}$ flux upwards across the tropical tropopause (about $0.03-0.1 \mathrm{Tg} \mathrm{a}^{-1}$ at $64 \mathrm{hPa}$ (Kotamarthi et al., 1994)) may be an important source in the lower tropical stratosphere (Murphy et al., 1993) but appears to be small compared to the production of $\mathrm{NO}_{\mathrm{y}}$ by $\mathrm{N}_{2} \mathrm{O}$ degradation $(0.2$ 
to $1 \mathrm{Tg} \mathrm{a}^{-1}$ ) (Murphy and Fahey, 1994; Müller and Brasseur, 1995; Lee et al., 1997; Lamarque et al., 1999; Martin et al., 2006).

Even though the contribution of $\mathrm{LNO}_{\mathrm{x}}$ to the total $\mathrm{NO}_{\mathrm{x}}$ budget is small, its contribution to the upper tropospheric $\mathrm{NO}_{\mathrm{x}}$ concentrations is large because of its comparatively long lifetime. For a source magnitude of between 4 and $8 \mathrm{Tg} \mathrm{a}^{-1}, \mathrm{LNO}_{\mathrm{x}}$ has been computed to be responsible for more than $70 \%$ of the $\mathrm{NO}_{\mathrm{x}}$ concentration in the upper troposphere in the subtropics and tropics, and for more than $20 \%$ in summer at higher latitudes (Lawrence et al., 1995; Brasseur et al., 1996; Levy II et al., 1996; Berntsen and Isaksen, 1999; Lelieveld and Dentener, 2000; Meijer et al., 2000; Grewe et al., 2001; Hauglustaine et al., 2001a; Jourdain and Hauglustaine, 2001; Tie et al., 2001; Zhang et al., 2003a; Sauvage et al., 2007b). These findings are illustrated by Fig. 17 showing the contributions from various sources to the $\mathrm{NO}_{\mathrm{y}}$ concentration as computed for a $\mathrm{LNO}_{\mathrm{x}}$ source of $5 \mathrm{Tg} \mathrm{a}^{-1}$ with the E39/C model (Grewe, 2007).

Lightning $\mathrm{NO}_{\mathrm{x}}$ is also responsible for a large fraction of the $\mathrm{O}_{3}$ produced in the troposphere, see Fig. 18, similar to Fig. 17 (Grewe, 2007). $\mathrm{NO}_{\mathrm{x}}$ in the upper troposphere is more effective in generating $\mathrm{O}_{3}$ than at the surface because of the longer lifetime and because of the lower background $\mathrm{NO}_{\mathrm{x}}$ concentration (see Fig. 1). $\mathrm{LNO}_{\mathrm{x}}$ was computed to be about 6 times more efficient in driving ozone production than anthropogenic $\mathrm{NO}_{\mathrm{x}}$ emissions (Wu et al., 2007). $\mathrm{NO}_{\mathrm{x}}$ emissions in the tropics are more efficient in producing $\mathrm{O}_{3}$ (because of higher photolysis rates) and changing $\mathrm{CH}_{4}$ lifetime (because of higher air temperatures) than the same emissions at higher latitudes (Crutzen et al., 1999; Hauglustaine et al., 2005; Naik et al., 2005). The production rate and the limiting value of $\mathrm{NO}_{\mathrm{x}}$, for which the production rate of $\mathrm{O}_{3}$ takes its maximum, is particularly large in the outflow from thunderstorm anvils because of high levels of humidity and $\mathrm{HO}_{\mathrm{x}}$ precursors like hydrogen peroxide $\left(\mathrm{H}_{2} \mathrm{O}_{2}\right)$, methylhydroperoxide $\left(\mathrm{CH}_{3} \mathrm{OOH}\right)$, and formaldehyde $(\mathrm{HCHO})$ transported upwards within the convective storm (Chatfield and Crutzen, 1984; Jaeglé et al., 1997; Prather and Jacob, 1997; Ko et al., 2003; DeCaria et al., 2005; Ott et al., 2007).

An increase in global tropospheric $\mathrm{O}_{3}$ of about 7-12\% is computed if the $\mathrm{LNO}_{\mathrm{x}}$ production is doubled from 5 to $10 \mathrm{Tg} \mathrm{a}^{-1}$ (Brasseur et al., 1996; Labrador et al., 2005). The mean tropical tropospheric ozone column increases by about $14 \%$ (26 to 29.6 Dobson units) for an increase of the $\mathrm{LNO}_{\mathrm{x}}$ source from 3 to $6 \mathrm{Tg} \mathrm{a}^{-1}$ (Martin et al., 2002b), or $10 \%$ for an increase from 3 to $8 \mathrm{Tg} \mathrm{a}^{-1}$ (Wild, 2007). Though $\mathrm{LNO}_{\mathrm{x}}$ (for a global $\mathrm{LNO}_{\mathrm{x}}$ source of $7 \mathrm{Tg} \mathrm{a}^{-1}$ ) contributes only to about $5 \%$ of the total USA $\mathrm{NO}_{\mathrm{x}}$ emissions, summer lightning may play a dominant role regionally and at certain times in controlling $\mathrm{NO}_{\mathrm{x}}$ and $\mathrm{O}_{3}$ concentrations in the middle and upper troposphere (Bond et al., 2001; Zhang et al., 2003b; Cooper et al., 2006).

Whereas the contributions of lightning to $\mathrm{NO}_{\mathrm{x}}$ concentrations have been detected from measurements in many cases, evidence for the $\mathrm{LNO}_{\mathrm{x}}$ influence on $\mathrm{O}_{3}$ via photochemistry is more difficult to derive from observations. This is because $\mathrm{O}_{3}$ production in the upper troposphere may take several days and hence is slow even though the number of $\mathrm{O}_{3}$ molecules produced per unit $\mathrm{NO}_{\mathrm{x}}$ consumed is high (Martin et al., 2000). Moreover, since deep convection plays a very important role in the vertical lofting of surface pollutants, it is very difficult to separate $\mathrm{O}_{3}$ contributions from lightning emissions in thunderstorms and from surface emissions (Schultz and Bey, 2004).

Nevertheless, the contribution of $\mathrm{LNO}_{\mathrm{x}}$ to ozone production has been identified from combined observation and model studies (Smyth et al., 1996b; Moxim and Levy II, 2000; Hauglustaine et al., 2001a; Martin et al., 2002b; Richter and Burrows, 2002; Ko et al., 2003; Roelofs et al., 2003; Sauvage et al., 2007a). For example, upper tropospheric lightning influence on $\mathrm{O}_{3}$ was identified over the North Atlantic (Brunner et al., 1998), the South tropical Atlantic and both adjacent continents (Pickering et al., 1996; Thompson et al., 2000a; Martin et al., 2002b; Peters et al., 2002), the Middle East and the Mediterranean ( $\mathrm{Li}$ et al., 2001), the tropical Pacific (Ko et al., 2003; Koike et al., 2003), the Southern Pacific (Staudt et al., 2002), over Africa (Marufu et al., 2000) and over North America (Cooper et al., 2006). $\mathrm{NO}_{\mathrm{x}}$ has been shown to be positively correlated with high $\mathrm{O}_{3}$ concentrations in the upper troposphere in about $100 \mathrm{~km}$ wide plumes from continental or lightning sources departing from the South-East USA over the Atlantic (Brunner et al., 1998). Li et al. (2001) explain 10-15\% of an upper tropospheric $\mathrm{O}_{3}$ maximum in the Middle East with $\mathrm{LNO}_{\mathrm{x}}$ contributions. Roelofs et al. (2003) estimate that $13 \%$ of upper tropospheric $\mathrm{O}_{3}$ over the Mediterranean is caused by $\mathrm{LNO}_{\mathrm{x}}$ but also note that the model underestimates the lightning contribution to $\mathrm{NO}_{\mathrm{x}}$ concentrations (Scheeren et al., 2003). Marufu et al. (2000) show that $27 \%$ of the tropospheric $\mathrm{O}_{3}$ abundance observed over Africa is caused by $\mathrm{LNO}_{\mathrm{x}}$, but also find that the representation of details of the $\mathrm{O}_{3}$ distribution suffers from imperfect $\mathrm{LNO}_{\mathrm{x}}$ source modelling. Cooper et al. (2006) performed an analysis of $\mathrm{O}_{3}$ profiles from measurements over midlatitude North America during July-August 2004; using a Lagrangian air parcel dispersion model, the upper tropospheric $\mathrm{O}_{3}$ enhancement was shown to be anti-correlated with tracers of surface emissions and positively correlated with tracers of $\mathrm{LNO}_{\mathrm{x}}$ sources. For a global $\mathrm{LNO}_{\mathrm{x}}$ source between 4.4 and $8.9 \mathrm{Tg} \mathrm{a}^{-1}$, they conclude that $\mathrm{LNO}_{\mathrm{x}}$ explains most of the identified upper tropospheric $\mathrm{O}_{3}$ enhancement. Over the Southern Pacific, biomass burning dominates the supply of $\mathrm{NO}_{\mathrm{x}}$ in the lower troposphere but $\mathrm{LNO}_{\mathrm{x}}$ dominates $\mathrm{NO}_{\mathrm{x}}$ in the upper troposphere and both make similar contributions to $\mathrm{O}_{3}$ production (Staudt et al., 2002). During the 1997 Indonesian fire episode, $\mathrm{LNO}_{\mathrm{x}}$ appears to be more important for $\mathrm{O}_{3}$ formation than the release of $\mathrm{NO}_{\mathrm{x}}$ from biomass fires (Duncan et al., 2003; Kita et al., 2003). 

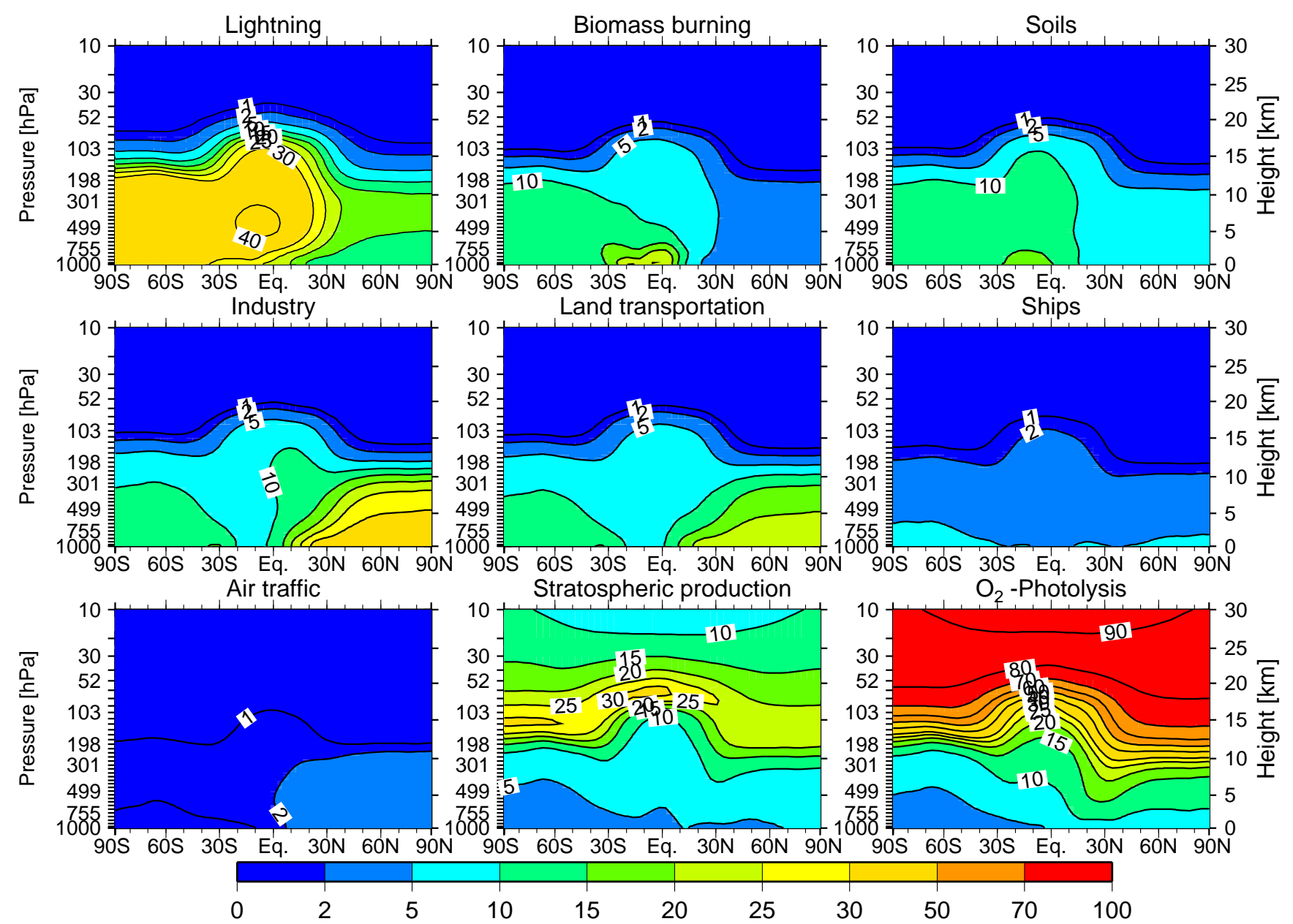

Fig. 18. Relative contributions $(\%)$ to the $\mathrm{O}_{3}$ budget from various sources as a function of latitude and pressure-altitude in the annual mean; figure from Grewe (2007), with kind permission of Elsevier.

Several studies (Martin et al., 2002b; Edwards et al., 2003; Jenkins et al., 2003; Chatfield et al., 2004) have explored the Atlantic "ozone paradox" (Thompson et al., 2000a), with high $\mathrm{O}_{3}$ over the Atlantic south of the Equator during the Northern African biomass burning season in DecemberFebruary (Weller et al., 1996; Thompson, 2004). This effect has been explained by the combination of upper tropospheric ozone production from lightning $\mathrm{NO}_{\mathrm{x}}$, persistent subsidence over the southern tropical Atlantic as part of the Walker circulation, and cross-equatorial transport of upper tropospheric ozone from northern midlatitudes (Martin et al., 2002b). A global lightning $\mathrm{NO}_{\mathrm{x}}$ source of $6 \mathrm{Tg} \mathrm{a}^{-1}$ in a global chemical transport model produces a simulation that is most consistent with analysis of tropospheric ozone column data derived from the Total Ozone Monitoring Spectrometer (TOMS), see Fig. 19 and Sect. 3.3.4. The explanation agrees with insitu observations of the transport of $\mathrm{O}_{3}$ precursors and other tracers across the inter-tropical convergence zone (ITCZ) in the December-January period during the TROPOZ II aircraft campaign (Jonquieres and Marenco, 1998), and with statis- tical analysis of correlations between tropospheric column $\mathrm{TOMS} \mathrm{O}_{3}$ data and OTD data of lightning flash rates (Martin et al., 2000; Ryu and Jenkins, 2005).

Finally, though much of the focus of lightning NOx research has been on its impact on ozone, it is also important for other trace gases. In particular, the relative change in mean tropospheric $\mathrm{OH}$ due to lightning is larger than the relative change in the ozone burden (Labrador et al., 2004), with important impact on the life time of methan and other gases (see Sect. 2.8). Furthermore, the $\mathrm{LNO}_{\mathrm{x}}$ source can contribute to $\mathrm{NO}_{3}$, which is known to be important for the oxidation of certain gases, such as the aerosol-precursor dimethylsulfide (DMS; Boucher et al., 2003). 

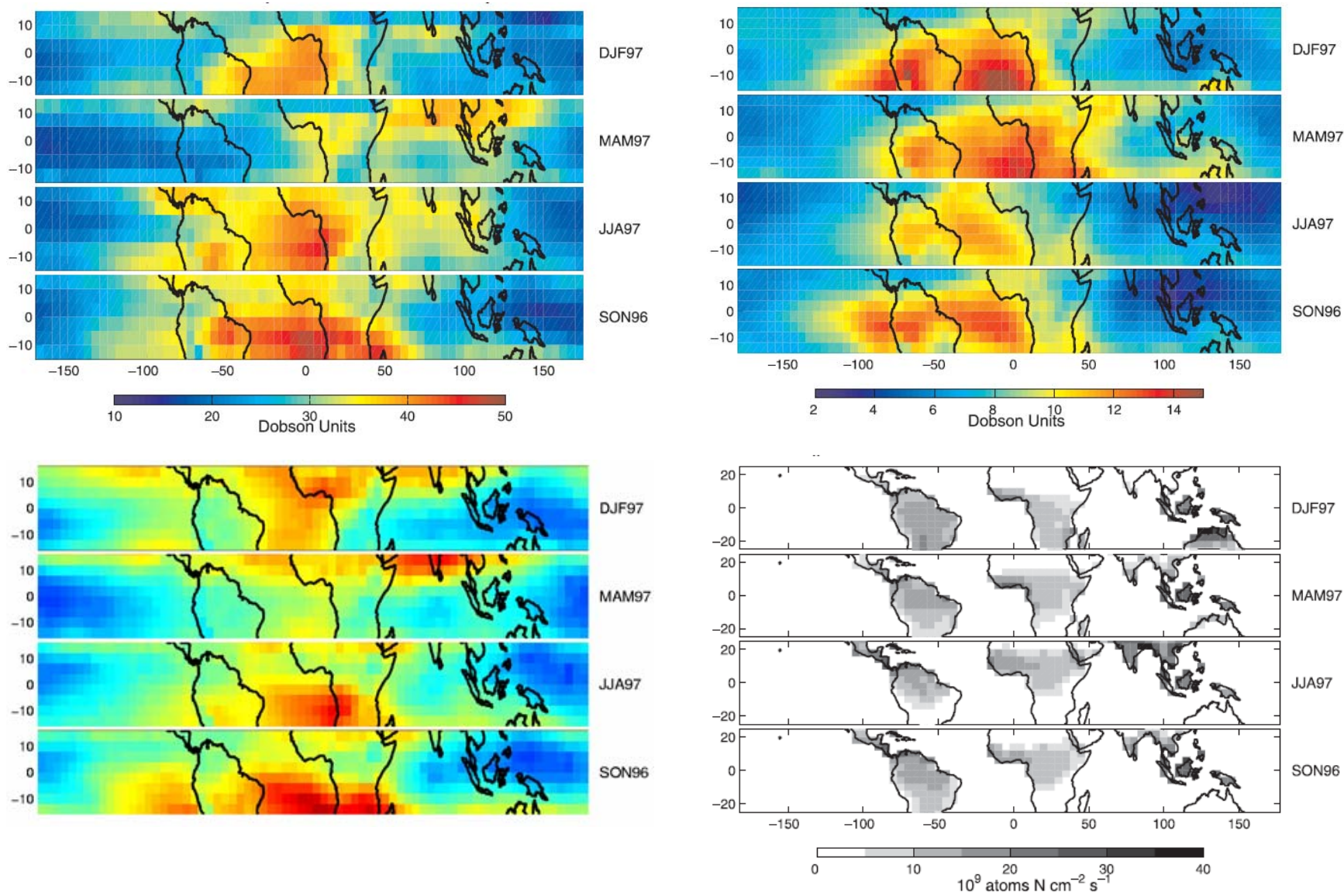

Fig. 19. Top left: Seasonally averaged and sensor efficiency corrected seasonally averaged tropical tropospheric ozone columns from TOMS for September 1996-August 1997. Bottom left: Comparable results from the model (GEOS-CHEM). Top right: Ozone column enhancement from lightning emissions in the model, as determined by difference from a simulation without lightning emissions. Bottom right: Seasonally averaged $\mathrm{NO}_{\mathrm{x}}$ emissions from lightning as computed using the cloud-top-height parameterisation in the model, yielding a global annual $\mathrm{LNO}_{\mathrm{x}}$ source of $6 \mathrm{Tg} \mathrm{a}^{-1}$ (Martin et al., 2002b).

\subsection{Global modelling of the $\mathrm{NO}_{\mathrm{x}}$ and $\mathrm{LNO}_{\mathrm{x}}$ distribution}

\subsubsection{Overview}

The contribution of lightning to the atmospheric composition can be computed using models representing lightning and its impact on atmospheric chemistry. In view of the random nature of lightning events and the large scale range involved between the local lightning and $\mathrm{LNO}_{\mathrm{x}}$ formation process and the driving outer parameters, this is not an easy task and has been accomplished so far only in a very approximate manner. Table 12 lists many of the 3-D global models used for assessing the effect and the size of $\mathrm{LNO}_{\mathrm{x}}$ sources on tropospheric chemistry. Cloud-scale models are discussed in Sect. 2.7.4. Recently, lightning has been addressed also in numerical weather prediction models (van den Broeke et al., 2005; Mansell et al., 2007).

At present only very few two-dimensional (2-D) and threedimensional (3-D) global models exist which explicitly simulate the storm electrification process with charge separation and lightning formation together with the $\mathrm{NO}_{\mathrm{x}}$ formation and the resultant tropospheric chemistry (Zhang et al., 2003b; 2003c). Instead most models parameterise the $\mathrm{LNO}_{\mathrm{x}}$ source distribution directly as a function of the meteorological variables in the model.

A chemical transport model (CTM) takes the meteorological fields from either a global circulation model (GCM) or from numerical weather prediction results (e.g. from the European Centre for Medium-Range Weather Forecasts, ECMWF or the National Center for Environmental Prediction, NCEP) (Rasch et al., 1997). GCMs compute their own meteorology in a climate mode. GCMs may also use the technique of "nudging" (i.e. temporal or Newtonian relaxation) to adjust the computed fields for observed situations using prescribed meteorological analysis fields (Jeuken et al., 1996). In early studies, the $\mathrm{LNO}_{\mathrm{x}}$ source was prescribed as fixed function of space and time. However, it was soon noted that the high spatial and temporal variability is of large importance for good comparisons with observations data (Flatøy and Hov, 1997; Stockwell et al., 1999). 
Table 12. Three-dimensional chemical atmospheric models.

\begin{tabular}{|c|c|c|c|c|c|c|c|c|c|c|c|}
\hline Year & Model* & $\begin{array}{l}\text { Wind } \\
\text { field }\end{array}$ & Lat & Lon & $\mathrm{V}$ & Top, hPa & $\begin{array}{l}\mathrm{G}, \\
\mathrm{Tg} \mathrm{a}^{-1}\end{array}$ & $\begin{array}{l}\text { Horizontal } \\
\text { distribution }\end{array}$ & $\begin{array}{l}\text { Vertical } \\
\text { distribution }\end{array}$ & $\mathrm{IC} / \mathrm{CG}$ & References \\
\hline 1984 & $\begin{array}{l}\text { MOGUNTIA } \\
\text { CTM }\end{array}$ & $\begin{array}{l}\text { Monthly } \\
\text { mean }\end{array}$ & $10^{\circ}$ & $10^{\circ}$ & 10 & 100 & $\begin{array}{l}5 \\
24.9)^{(0-}\end{array}$ & constant, CTH & $\begin{array}{l}\text { constant mixing } \\
\text { ratio }\end{array}$ & $0.1,1$ & $\begin{array}{l}\text { Zimmermann (1988); Dentener and Crutzen } \\
\text { (1993); Lelieveld and Crutzen (1994); Gallardo } \\
\text { and Rodhe (1997); Lelieveld et al. (1998) }\end{array}$ \\
\hline 1991 & Lagrangian transport & GCM & $4.5^{\circ}$ & $7.5^{\circ}$ & 12 & 9 & $3-12.9$ & constant & constant density & & Penner et al. (1991) \\
\hline 1995 & $\begin{array}{l}\text { NCAR MACCM, } \\
\text { GCM/CCM }\end{array}$ & & $5^{\circ}$ & $4^{\circ}$ & 52 & 0.005 & 5 & & & & $\begin{array}{l}\text { Rasch et al. (1995); Boville (1995); Gauss et } \\
\text { al. (2006) }\end{array}$ \\
\hline 1996 & NORLAM CTM & & & & & & 5 & constant, PR92 & constant & 0.1 & Flatøy and Hov (1997) \\
\hline 1996 & GFDL GCTM & GCM & $2.4^{\circ}$ & $265 \mathrm{~km}$ & 11 & 10 & $4(2-6)$ & PR92 & constant $<7 \mathrm{~km}$ & 0.1 & Levy et al. (1996, 1999); Emmons et al. (1997); \\
\hline 1996 & $\begin{array}{l}\text { IMAGES } \\
\text { CTM }\end{array}$ & $\begin{array}{l}\text { Monthly } \\
\text { ECMWF }\end{array}$ & $5^{\circ}$ & $5^{\circ}$ & 25 & 50 & $\begin{array}{l}5, \quad(2- \\
10) \\
3\end{array}$ & TE82 & constant & 0.1 & $\begin{array}{l}\text { Müller and Brasseur (1995, 1999); Brasseur et } \\
\text { al. (1996); Lamarque et al. (1996); Emmons } \\
\text { et al. (1997); Thakur et al. (1999); Granier et } \\
\text { al. (2000) }\end{array}$ \\
\hline 1996 & $\begin{array}{l}\text { GRANTOUR, La- } \\
\text { grangian transport } \\
\text { CTM }\end{array}$ & GCM & $4.5^{\circ}$ & $7.5^{\circ}$ & 12 & 9 & $7(2-12)$ & P97 & P98 & 0.1 & Emmons et al. (1997); Penner et al. (1998) \\
\hline 1997 & CTM2, UiO-CTM & GCM & $8^{\circ}$ & $10^{\circ}$ & 9 & 10 & $\begin{array}{l}5.7 \\
(12.2)\end{array}$ & constant & constant & 0.1 & $\begin{array}{l}\text { Berntsen and Isaksen (1997, 1999); Jaffe et } \\
\text { al. (1997) }\end{array}$ \\
\hline 1997 & STOCHEM, CTM & GCM & $5^{\circ}$ & $5^{\circ}$ & 9 & 100 & 7 & PR97, CPR & constant density & & $\begin{array}{l}\text { Collins et al. (1997); Stevenson et al. (2004); } \\
\text { Sanderson et al. (2006) }\end{array}$ \\
\hline 1997 & MATCH, CTM & GCM & $500 \mathrm{~km}$ & $500 \mathrm{~km}$ & 21 & 50 & 2 & PR92 & constant & & Rasch et al. (1997); Lawrence et al. (1999) \\
\hline 1998 & $\begin{array}{l}\text { GEOS-CHEM, } \\
\text { GCM (3-D Harvard) }\end{array}$ & $\mathrm{GCM}$ & $4^{\circ}$ & $5^{\circ}$ & 9 & 10 & $1-3.5$ & PR92 & P98 & $1 / 3$ & $\begin{array}{l}\text { Wang et al. (1998b); Mickley et al. (1999); } \\
\text { Horowitz et al. (1999); Bey et al. (2001); Martin } \\
\text { et al. (2002b) }\end{array}$ \\
\hline 1998 & MOZART, CTM & GCM & $2.8^{\circ}$ & $2.8^{\circ}$ & 25 & 3 & $7(3)$ & PR92, PR97 & constant density & & $\begin{array}{l}\text { Emmons et al. (1997, 2000); Brasseur et } \\
\text { al. (1998b); Hauglustaine et al. (1998, 2001a); } \\
\text { Thakur et al. (1999); Tie et al. (2001) }\end{array}$ \\
\hline 1998 & CTMK, СТM & ECMWF & $4^{\circ}$ & $5^{\circ}$ & 15 & 12.7 & 5 & constant, PR92 & constant & & Wauben et al. (1997); Emmons et al. (1997) \\
\hline 1998 & $\begin{array}{l}\text { TOMCAT, tropo- } \\
\text { spheric CTM }\end{array}$ & ECMWF & $5.6^{\circ}$ & $5.6^{\circ}$ & 31 & & 4 & CTH PR92 & $\begin{array}{l}\text { different for CG } \\
\text { and IC }\end{array}$ & & $\begin{array}{l}\text { Law et al. (1998); Stockwell et al. (1999); Savage } \\
\text { et al. (2004) }\end{array}$ \\
\hline 2000 & ECHAM4 & ECMWF & $3.75^{\circ}$ & $5^{\circ}$ & 19 & 10 & 4,5 & PR92, DC93 & & & $\begin{array}{l}\text { Roelofs and Lelieveld (1995, 2000); Lelieveld and } \\
\text { Dentener (2000); Marufu et al. (2000) }\end{array}$ \\
\hline
\end{tabular}


Table 12. Continued.

\begin{tabular}{|c|c|c|c|c|c|c|c|c|c|c|c|}
\hline Year & Model $^{*}$ & $\begin{array}{l}\text { Wind } \\
\text { field }\end{array}$ & Lat & Lon & $\mathrm{V}$ & Top, hPa & $\begin{array}{l}\mathrm{G}, \\
\mathrm{Tg} \mathrm{a}^{-1}\end{array}$ & $\begin{array}{l}\text { Horizontal } \\
\text { distribution }\end{array}$ & $\begin{array}{l}\text { Vertical } \\
\text { distribution }\end{array}$ & $\mathrm{IC} / \mathrm{CG}$ & References \\
\hline 2000 & FRSGC-UCI, CTM & ECMWF & $2.8^{\circ}$ & $2.8^{\circ}$ & 37 & 10 & 5 & PR92 & & & Wild and Prather (2000); Wild et al. (2003) \\
\hline 2000 & TM3, CTM & ECMWF & $3.75^{\circ}$ & $5^{\circ}$ & 19 & 10 & 5 & PR92 & constant density & $1 / 3$ & Meijer et al. (2000, 2001); Peters et al. (2002) \\
\hline 2001 & GISS, GCM & GCM & & & & & 3.9 & P97 modified & P98 & 0.1 & Grewe et al. (2001); Shindell et al. $(2001,2003)$ \\
\hline 2001 & DLR E39/C, GCM & GCM & $3.8^{\circ}$ & $3.8^{\circ}$ & 39 & 10 & $\sim 5.4$ & PR94 or UPD & P98 & & $\begin{array}{l}\text { Grewe et al. (2001, 2002); Hein et al. (2001); Kurz } \\
\text { and Grewe (2002); Stenke and Grewe (2004); } \\
\text { Dameris et al. (2005) }\end{array}$ \\
\hline 2002 & $\begin{array}{l}\text { CHASER, GCM and } \\
\text { CTM }\end{array}$ & CCM & $2.8^{\circ}$ & $2.8^{\circ}$ & 32 & 3 & 5 & PR92 & P98 & 0.1 & Sudo et al. (2002a, b); Gauss et al. (2006) \\
\hline 2003 & UIO-CTM2, CTM & & $2.8^{\circ}$ & $2.8^{\circ}$ & 40 & 10 & 5 & PR97 & & & Gauss et al. (2006) \\
\hline 2003 & $\begin{array}{l}\text { STOCHEM }- \\
\text { HadGEM1, GCM }\end{array}$ & $\mathrm{CCM}$ & $2.5^{\circ}$ & $3.8^{\circ}$ & 20 & 4 & 8 & PR92 & PR97 & & Collins et al. (2003) \\
\hline 2003 & $\begin{array}{l}\text { MATCH-MPIC, } \\
\text { CTM }\end{array}$ & $\mathrm{CCM}$ & $1.9-5.6^{\circ}$ & $1.9-5.6^{\circ}$ & 28 & 3 & $2-2.8$ & CTH, PR92 & 3 versions & & $\begin{array}{l}\text { von Kuhlmann et al. (2003a, b); Kunhikrishnan et } \\
\text { al. (2004); Labrador et al. (2005) }\end{array}$ \\
\hline 2003 & MOZART 2 & $\begin{array}{l}\text { GCM or } \\
\text { NCEP } \\
\text { or } \\
\text { ECMWF }\end{array}$ & $2.8^{\circ}$ & $2.8^{\circ}$ & 34 & 4 & 3 & CTH, PR92 & P98 & & $\begin{array}{l}\text { Horowitz et al. (2003); Brasseur et al. (2006); Mu- } \\
\text { razaki and Hess (2006) }\end{array}$ \\
\hline 2004 & LMDz/INCA, CCM & $\begin{array}{l}\text { Nudging } \\
\text { of } \\
\text { ECMWF }\end{array}$ & $2.5^{\circ}$ & $3.8^{\circ}$ & 19 & 3 & 5 & $\mathrm{CTH}$ & PR97 & & Hauglustaine et al. $(2004,2005)$ \\
\hline 2006 & $\begin{array}{l}\text { ECHAM5/MESSy, } \\
\text { GCM/CTM }\end{array}$ & $\begin{array}{l}\text { GCM } \\
\text { nudged } \\
\text { to } \\
\text { ECMWF }\end{array}$ & $1.9^{\circ}$ & $1.9^{\circ}$ & 19 & 10 & 5 & $\begin{array}{l}\text { UPD or CTH } \\
\text { PR92 }\end{array}$ & P98 & 1 & Kurz (2006) \\
\hline 2006 & $\begin{array}{l}\text { ECHAM5/MESSy } 1 \text {, } \\
\text { GCM/CTM }\end{array}$ & $\begin{array}{l}\text { GCM } \\
\text { nudged } \\
\text { to } \\
\text { ECMWF }\end{array}$ & $2.8^{\circ}$ & $2.8^{\circ}$ & 90 & 0.01 & 2.2 & $\mathrm{CTH}$ & P98 & & Jöckel et al. (2006) \\
\hline
\end{tabular}

*CTM: Chemical Transport Model; GCM: General Circulation Model; CCM: coupled Chemistry-Climate Model; Year: Year of Publication; Lat: Latitudinal resolution; Lon: Longitudinal resolution; V: Number of vertical levels; Top: Model top boundary altitude; G: Global and annual $\mathrm{LNO}_{\mathrm{x}}$ nitrogen mass source, $\mathrm{Tg} \mathrm{a}{ }^{-1}$; IC/CG: NO production rate per IC and CG flash ratio, partly cited from Zhang et al. (2003b); DC93: Dentener and Crutzen (1993); PR92: Price and Rind (1992); PR97: Price et al. (1997b). P98: Pickering et al. (1998); TE82: Turman and Edgar (1982). CPR: Convective precipitation rate (Meijer et al., 2001); CTH: Cloud-top-height (Price et al., 1997b); UPD: updraft velocity (Grewe et al., 2001). 
Fundamental to this approach is the assumption that the meteorological fields used represent the convection which causes lightning. Convection is driven by locally generated or advected hot and moist air masses in the boundary layer causing convective instability, enhanced by advection of cool air masses in the upper troposphere, wind shear, and lowlevel convergence and upper level divergence of horizontal wind fields (Cotton and Anthes, 1989; Johnson and Mapes, 2001). Hence, it covers a wide range of scales. So far cloudscale convection is parameterised in global weather and climate models either by moist adiabatic convective adjustment of unstable temperature profiles (Manabe et al., 1965), mass flux schemes (Tiedtke, 1989; Hack, 1994), or convective cloud models (Zhang and McFarlane, 1995). The convective adjustment approach does not provide information on the convective process. The mass flux schemes determine the overall mass flux for all cumulus clouds in one grid cell column. Convective cloud models simulate an ensemble of subgrid clouds with different horizontal cloud diameters and updrafts speeds and may include aerosol effects (Nober and Graf, 2005). Details of the parameterisations have large effects on $\mathrm{LNO}_{\mathrm{x}}$ relevant cloud parameters including precipitation (Arakawa, 2004; Tost et al., 2006). Cloud-resolving models may be able to resolve convection which occurs as singlecell, multicell and supercell convective storms and MCS (Maddox, 1980; Houze, 2004). The large-scale models should be able to resolve the "warm conveyor belt" of midlatitude cyclones contributing to long-distance trace species transport (Browning, 1990; Stohl et al., 2003; Huntrieser et al., 2005). CTMs are often tested in their ability to represent the transport and chemistry of species for given meteorology (Brunner et al., 2003, 2005; Zhang et al., 2003b; Eyring et al., 2006; Gauss et al., 2006; Stevenson et al., 2006; van Noije et al., 2006). Relatively less attention has been given to validate the (often coarsely represented or simplified) meteorological fields and processes used in driving the transport and chemistry in the CTM.

\subsubsection{Lightning parameterisation based on cloud-top- height}

$\mathrm{LNO}_{\mathrm{x}}$ parameterisation in the models compute the spatial distribution of lightning events, the relative contribution from CG and IC flashes, and the vertical extent and profile of the resultant $\mathrm{LNO}_{\mathrm{x}}$ emissions as a function of the given meteorology. The globally averaged $\mathrm{LNO}_{\mathrm{x}}$ source is usually adjusted to some pre-selected value.

Many models rely on the work of Price and Rind (1992) and Price et al. (1997b) who parameterised the spatial distribution of the flash frequency as a function of the maximum cloud-top-height $(\mathrm{CTH})$. This allows to proxy lightning rates from observable large-scale parameters. Different parameterisations were used for continental and maritime thunderstorms. The parameterisation for continental thunderstorms is based on theories and observations showing that lightning frequencies in continental thunderstorms are related to the fifth power of the cloud height (Vonnegut, 1963; Williams, 1985). The parameterisation for maritime thunderstorms is based on observations indicating that marine thunderstorms with the same CTH have weaker updrafts, resulting in lower lightning frequencies (Lucas et al., 1994b; Zipser et al., 2006). The relationships used are

$F_{c}=3.44 \times 10^{-5} H^{4.9}, F_{m}=6.40 \times 10^{-4} H^{1.73}$,

where $F_{c}$ and $F_{m}$ are the continental and maritime flash frequencies (flashes per minute), respectively, and $H$ is the cloud-top height above ground $(\mathrm{km})$. Storms up to $500 \mathrm{~km}$ from the coastlines are still regarded as being continental in nature (Price and Rind, 1992); in fact storms with strong lightning activity occur also in oceanic regions with lowlevel outflow of warm and humid air masses from the adjacent land region, such as to the east of North America, east of South Africa around Madagascar, east of South America and east of the Indian subcontinent ("continental oceans" (Takayabu, 2006)).

The approach of Price et al. distinguishes between CG and IC flashes. CG flashes were expected to be less frequent but more energetic. The fraction of CG flashes relative to total flash frequency is parameterised as a function of the thickness of the cold cloud layer (between $0^{\circ} \mathrm{C}$ and cloud top) (Price and Rind, 1993). Price et al. (1997b) apply the model to satellite-derived cloud-top-heights assuming a discharge energy per CG flash of $6.7 \mathrm{GJ}$ and a NO molecule production rate per discharge energy of $10 \times 10^{16} \mathrm{~J}^{-1}$. This implies a total annual $\mathrm{LNO}_{\mathrm{x}}$ nitrogen mass emission rate of $12.2 \mathrm{Tg} \mathrm{a}^{-1}$.

The $\mathrm{LNO}_{\mathrm{x}}$ source is distributed vertically within global atmospheric models using an effective vertical emission profile (Pickering et al., 1998). The altitude of the convective outflow has important implications for the transport speed and direction and it determines the chemical lifetime of the lofted pollutant species, and the large-scale $\mathrm{NO}_{\mathrm{x}}$ distribution is sensitive to the shape of the profiles (Labrador et al., 2005). The models do not resolve the mixing processes in individual storms which occur at spatial and temporal scales far smaller than resolvable in global models, and the emissions are not distributed according to the vertical distribution of the CG and IC flash events. Instead the effective vertical emission profile describes the outflow pattern of $\mathrm{LNO}_{\mathrm{x}}$ from the thunderstorms. Until now, the relative importance of the various outflow domains is uncertain.

Various forms of effective vertical emission profiles have been used so far; see Fig. 20. At early times, models assumed profiles which are constant with altitude from ground to cloud top either in terms of constant mass density or constant mixing ratio (Lamarque et al., 1996). The latter would result from complete vertical mixing by convection. The vertical distribution of the $\mathrm{LNO}_{\mathrm{x}}$ outflow depends strongly on the specific storm properties, and consequently different profiles may be needed for different (e.g. oceanic/continental, tropical/midlatitude) storm types (Pickering et al., 1998). 


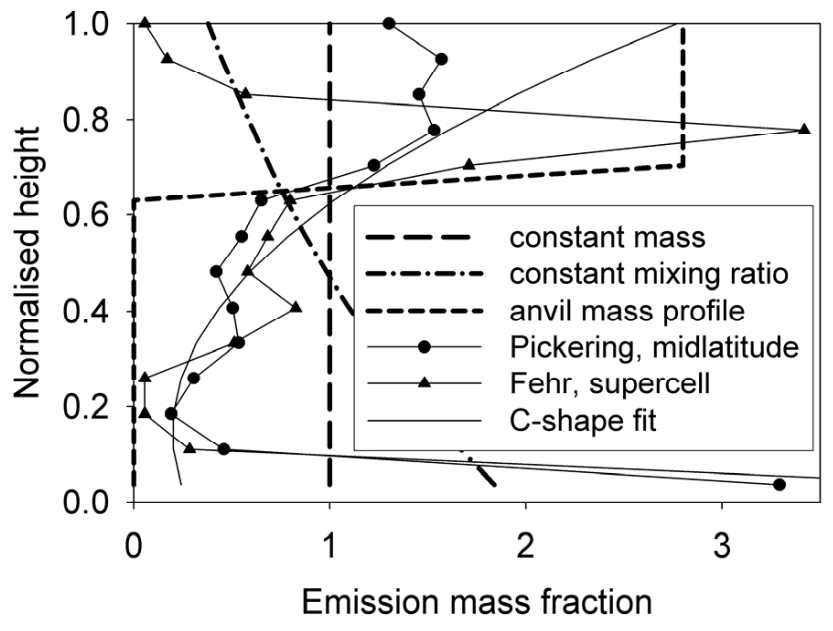

Fig. 20. $\mathrm{LNO}_{\mathrm{x}}$ mass emission profiles for a convective system with altitude normalised to cloud top height: constant mass (longdashed), constant mixing ratio (dash-dotted), constant mass flux from anvil (short dashed), midlatitude storm outflow profile (thin line with dots) (Pickering et al., 1998), midlatitudes supercell outflow profile (thin line with triangles) (Fehr et al., 2004), quadratic parabola C-shape fit (thin line) (Kurz and Grewe, 2002).

Observations show clearly that part of the $\mathrm{LNO}_{\mathrm{x}}$ gets released to the environment from thunderstorms within the anvils (Huntrieser et al., 1998; Ridley et al., 2004). Some $\mathrm{LNO}_{\mathrm{x}}$ fraction may get transported downwards with downdrafts as indicated in some cloud-resolving model studies (Pickering et al., 1998; DeCaria et al., 2000; Skamarock et al., 2003; Zhang et al., 2003c; Fehr et al., 2004). Therefore, many authors assume that the emission profile has a C-shape profile similar to the C-shape fit used by Kurz and Grewe (2002) to approximate those computed by Pickering et al. (1998). However, observational evidence for $\mathrm{LNO}_{\mathrm{x}}$ entering the planetary boundary layer with downdrafts is missing. It would be difficult to find because of shorter lifetime and higher background $\mathrm{NO}_{\mathrm{x}}$ concentration in the boundary layer, and the difficulty to measure at the right place and time. Simulations for observed STERAO, EULINOX and TROCCINOX cases show no significant $\mathrm{NO}_{\mathrm{x}}$ outflow below about $4 \mathrm{~km}$ altitude, consistent with observations (DeCaria et al., 2005; Mari et al., 2006; Ott et al., 2007).

\subsubsection{Alternative lightning parameterisations}

CTH does not primarily control the formation of lightning, and the fundamental limitations of the CTH approach have often been discussed (Molinié and Pontikis, 1995; Price et al., 1997b; Ushio et al., 2001; Allen and Pickering, 2002; Boccippio, 2002; Cecil et al., 2005). The cloud top heights may be large without active updrafts and hence without active lightning. Later, other approaches were developed based on a combination of latent heat release and cloud-top-height
(Flatøy and Hov, 1997), convective precipitation rate (CPR) (Meijer et al., 2001; Allen and Pickering, 2002), convective available potential energy (CAPE) (Choi et al., 2005), land-ocean cloud CCN spectrum differences (Michalon et al., 1999; Jourdain and Hauglustaine, 2001), or convectively induced updraft velocity (UPD) (Allen et al., 2000; Grewe et al., 2001; Allen and Pickering, 2002; Kurz and Grewe, 2002). Besides a few observations (Lhermitte and Krehbiel, 1979), conceptual flash models indicate that flash rates are correlated with a high power (order of six) of the strength of storm updrafts (Baker et al., 1995, 1999).

Figure 21 illustrates the capability of the parameterisations, namely $\mathrm{CTH}, \mathrm{CPR}$ and UPD in various models for the February 2005 TROCCINOX period. In comparison to the LIS data, the three models all represent the observed spatial distribution of lightning activity reasonably; in particular, they simulate the observed maximum values over the tropical continents (Africa, South America and the region between Indonesia and North Australia). The UPD scheme underestimates lightning at Northern midlatitudes, the CPR overestimates lightning in the ITCZ, and the CTH model underestimates the lightning activity in Northern Argentina. Obviously, there is a need for further improvements. Recently, Tost et al. (2007) compared several combinations of state-ofthe-art convection and lightning parameterisations. Model simulations with the global atmospheric chemistry model ECHAM5/MESSy were evaluated against lightning observations. A wide range in the spatial and temporal variability of the simulated flash densities was found, attributed to both types of parameterisations.

Allen et al. (2000) studied the impact of lightning on total odd nitrogen in the North Atlantic in a CTM calculation driven by fields from the Goddard Earth Observing System Data Assimilation System (GEOS DAS). CTH-based flash rates over the western Atlantic and Gulf Stream were much lower than observed during SONEX. In addition, the fifth power dependence of flash rate on cloud top height made this method very sensitive to biases in GEOS DAS cloud top heights. For these reasons, they developed an alternative UPD method that relates the CG flash rate to the GCMcalculated convective mass flux. Allen and Pickering (2002) tested various parameterisations including UPD, CPR and $\mathrm{CTH}$. Their UPD variant relates the flash frequency to a fourth order polynomial of the grid cell mean upward flux at $440 \mathrm{hPa}$ as derived from a meteorological data assimilation system regardless of type of land surface. The polynomial parameters were derived by fitting model results to groundbased lightning frequency observations. They compared the computed flash rates with satellite and ground-based lightning observations. The CTH parameterisation tends to underestimate lightning over marine locations while the UPD and CPR parameterisations have the opposite problem (Allen and Pickering, 2002). The UPD variant appears most realistic. Allen and Pickering (2002) noted that improvements in flash rate parameterisations will be tied closely to 


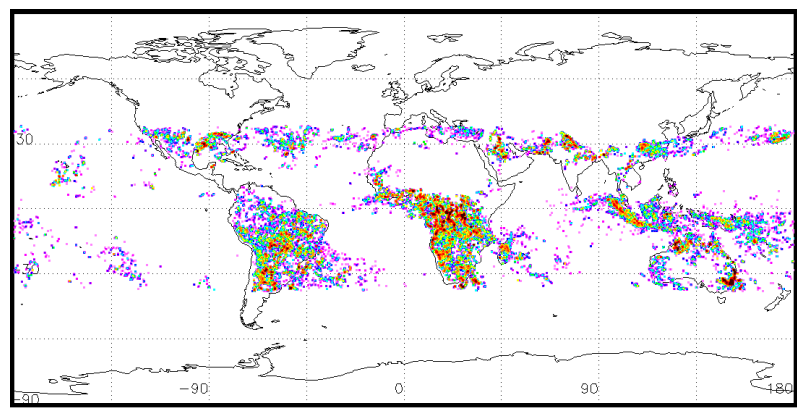

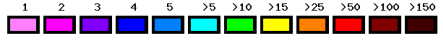

(a)

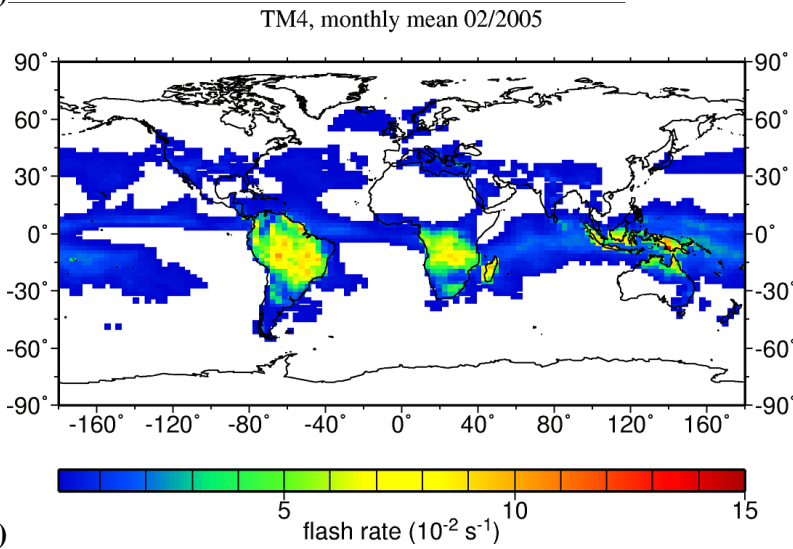

E5M1 UPD, monthly mean 02/2005

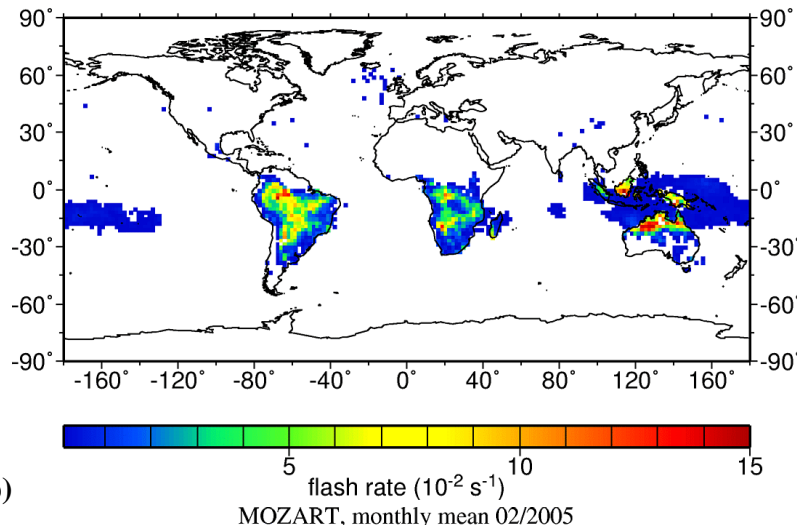

MOZART, monthly mean $02 / 2005$

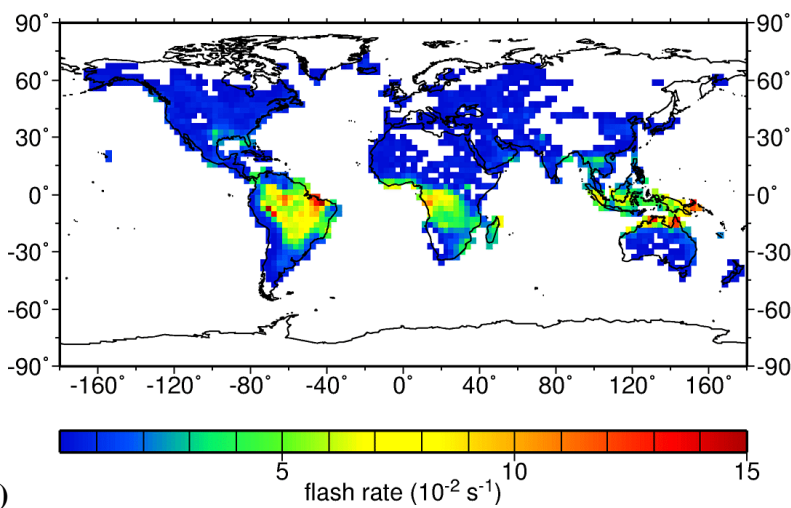

Fig. 21. Observed and computed lightning flash density for February 2004. Top left: LIS (NASA), top right: MOZART, CTH (L. Emmons), Bottom left: ECHAM5/MESSy, UPD (C. Kurz), bottom right: TM4, CPR (E. Meijer).

improvements in modelling the convection physics. Allen and Pickering (2002) applied their model with global $\mathrm{LNO}_{\mathrm{x}}$ values between 0.1 and $35.2 \mathrm{Tg} \mathrm{a}^{-1}$, but did not derive explicit conclusions on the best $\mathrm{LNO}_{\mathrm{x}}$ source values.

Grewe et al. (2001) independently introduced a parameterisation variant based on convective updrafts (UPD) velocities. They used a global circulation model E39/C coupled to a chemical model. The convective updrafts (typically a few $\mathrm{km}$ wide) have to be parameterised in such models with grid scales of the order of a few $100 \mathrm{~km}$. The GCM computes a mean upward convective mass flux $m f_{i}\left(\right.$ in $\mathrm{kg} \mathrm{m}^{-2} \mathrm{~s}^{-1}$ ) in a grid cell at each vertical level $i$ using a classical parameterisation (Tiedtke, 1989). From this Grewe et al. computed an indicator for the (grid cell average) updraft velocity

$w=\Sigma\left(m f_{i} / \rho_{i}\right)\left(h_{i} / D\right)$,

with the cloud thickness $D=\Sigma h_{i}(m), \rho_{i}$ the mass density $\left(\mathrm{kg} \mathrm{m}^{-3}\right)$, and $h_{i}(\mathrm{~m})$ the thickness of the cloud layer $i$, where $\Sigma$ denotes summation over the cloud layers $i$ from cloud bottom to cloud top in the grid cell. The cloud-top-height $H$, the mass-flux-derived updraft velocity $w\left(\mathrm{~m} \mathrm{~s}^{-1}\right)$, and the cloud height $D$ are related to each other by

$H=a w D^{1 / 2}$,

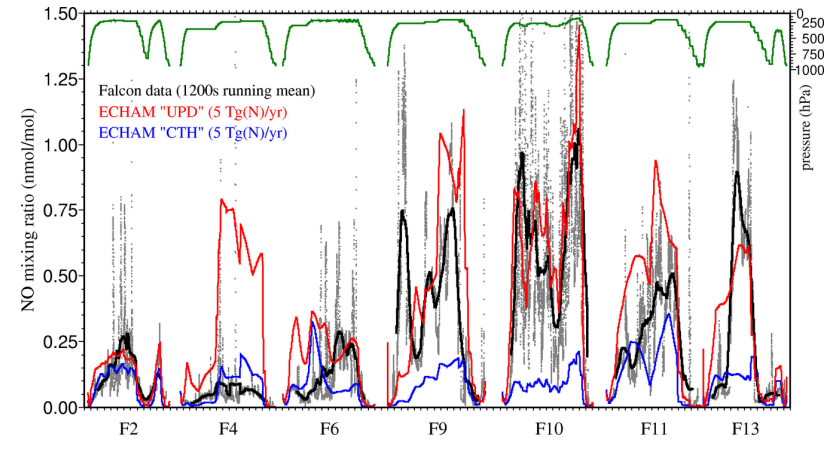

Fig. 22. NO mixing ratio $\left(\mathrm{nmol} \mathrm{mol}{ }^{-1}\right)$ versus time. The total time amounts to about $30 \mathrm{~h}$. Measured values (dots and line, mean value for a running average over $1200 \mathrm{~s}$ ), and results for ECHAM UPD (red) and ECHAM CTH (blue), both for $5 \mathrm{Tg} \mathrm{a}^{-1}$. TROCCINOX flights F2 (14 February), F4 (17 February), F6 (20 February), F9 und F10 (morning and afternoon of 3 March), F11 (4 March), and F13 (7 March, 2004) (Kurz, 2006).

where $a=0.85$ was selected to achieve consistency with Price and Rind (1992). Inserting this into the equation for $F_{c}$ gives 
Table 13. "Lightning yield", i.e., number of CG flashes per rain mass.

\begin{tabular}{|c|c|c|}
\hline Region & Lightning yield, $\mathrm{Tg}^{-1}$ & Reference \\
\hline Florida & 50 & Piepgrass et al. (1982); Gungle and Krider (2006) \\
\hline Arizona & $15-33$ & Battan (1965) \\
\hline Congo & 30 & $\begin{array}{l}1550 \mathrm{~mm} \text { rain } \mathrm{a}^{-1}, \sim 45 \text { flashes } \mathrm{km}^{-2} \mathrm{a}^{-1} \\
\text { (Williams and Sátori, 2004) }\end{array}$ \\
\hline Arid south-western USA & 15 & Petersen and Rutledge (1998) \\
\hline Midcontinental USA & 10 & Petersen and Rutledge (1998) \\
\hline Amazonas & 10 & $\begin{array}{l}2150 \mathrm{~mm} \text { rain } \mathrm{a}^{-1}, \sim 20 \text { flashes } \mathrm{km}^{-2} \mathrm{a}^{-1} \\
\text { (Williams and Sátori, 2004) }\end{array}$ \\
\hline Continental Australia & 4 & Jayaratne and Kuleshov (2006) \\
\hline Mediterranean regions & $1-4$ & Price and Federmesser (2006) \\
\hline Tropical continent & 2.5 & Petersen and Rutledge (1998) \\
\hline Tropical land $36^{\circ} \mathrm{S}-36^{\circ} \mathrm{N}$ & $2.5 *)$ & Takayabu (2006) \\
\hline Summer stations Australia & 1.9 & Jayaratne and Kuleshov (2006) \\
\hline Coastal Australia & 1 & Jayaratne and Kuleshov (2006) \\
\hline Winter stations Australia & 0.77 & Jayaratne and Kuleshov (2006) \\
\hline Tropical oceans $36^{\circ} \mathrm{S}-36^{\circ} \mathrm{N}$ & $0.5 *)$ & Takayabu (2006) \\
\hline Tropical thunderstorm & 0.12 & Williams et al. (1992) \\
\hline Tropical Pacific Ocean & 0.1 & Petersen and Rutledge (1998) \\
\hline
\end{tabular}

*) Lightning yield for total flash number derived from 3 years of TRMM precipitation radar-based rainfall amount and LIS flash data.

$$
\begin{aligned}
& \text { a flash frequency } \\
& \begin{aligned}
F & =3.44 \times 10^{-5} H^{4.9} \\
& =3.44 \times 10^{-5}\left(a w D^{1 / 2}\right)^{4.9} \\
& =1.54 \times 10^{-5}\left(w D^{1 / 2}\right)^{4.9}
\end{aligned}
\end{aligned}
$$

The model simulates different convective mass fluxes over land and sea, and provides a non-perfect but reasonable approximation for the lightning land-ocean contrast without using different sets of model parameters as was necessary in the CTH parameterisation. The dependence of $F$ on $D$ prevents lightning in shallow convection (Grewe, 2007). The model of Grewe et al. (2001) further assumes that the ratio of IC to CG flashes is determined as in Price and Rind (1993). The vertical distribution of the $\mathrm{LNO}_{\mathrm{x}}$ emissions follows Pickering et al. (1998), and the total annual emission of $\mathrm{LNO}_{\mathrm{x}}$ was scaled to $5 \mathrm{Tg} \mathrm{a}^{-1}$. Hence, the UPD model is both consistent with theoretical expectations and experiences with the CTH model, but without the need for different types of parameterisations for land and sea. Still, the mean velocity averaged over the cell differs from the mean velocity in the cloud cores, in particular if the cell is only partially clouded. Kurz (2006) presents a case study for Brazil and computes peak convective mass flux values of $0.3 \mathrm{~kg} \mathrm{~m}^{-2} \mathrm{~s}^{-1}$, implying peak velocities of about $1 \mathrm{~m} \mathrm{~s}^{-1}$ in the upper troposphere. It is not yet clear whether the approach is invariant with respect to grid scale variations. It is to be expected that the results are sensitive to details in the convection parameterisation (Tost et al., 2006). Moreover, not all CTMs have access to meteorological input for convective mass flux. Unfortunately, simultaneous global observations of lightning and updraft speeds in convection are missing, meaning that this approach is hard to validate.

Systematic comparisons of the performance of various lightning parameterisations in terms of flash frequencies, land-ocean contrast, latitudinal variations, Congo-Amazoncontrast, daily and seasonal cycles, and spatial and temporal variability are rare. Model comparisons with observed precipitation features (Zipser et al., 2006) have still to be performed. CTH based flash rates, scaled to an assumed total $\mathrm{LNO}_{\mathrm{x}}$ source rate, have been compared with OTD/LIS data in a few model studies (Shindell et al., 2001; Martin et al., 2002b; Hauglustaine et al., 2004; Labrador et al., 2005). The models reproduce the main features of the observed daily and seasonal cycle and the general location of convective regions, but otherwise the agreement is not quantified and several disagreements were noted. In a recent study with the GEOS-CHEM model, the seasonal correlation coefficients between CTH-derived flash frequencies and OTD/LIS observations varied between 0.4 and 0.57 ; a far higher correlation (0.97-0.98) was obtained after scaling the model results locally to fit observed seasonal mean values (Martin et al., 2007; Sauvage et al., 2007a).

The CPR lightning parameterisation assumes a fixed 'rain yield', i.e. mass of rain produced per lightning CG flash. Actually relevant is the inverse, i.e. the "lightning yield" (Williams et al., 2002). Though lightning may occur also without rain (Rorig and Ferguson, 2002), the lightning yield is mostly finite, and has been reported to vary within $0.1-$ $50 \mathrm{Tg}^{-1}$, see Table 13 (for further studies see MacGorman and Rust, 1998, and Rakov and Uman, 2003). Note that the 
TRMM data refer to total flash rates while all other data refer to $\mathrm{CG}$ flashes. For the same rain rate, more CG flashes are produced over continents than oceans and more at midlatitudes than in the tropics. On average, the lightning yield is 3 times smaller over ocean than over land (Takayabu, 2006) and about 3 times smaller over the Amazon than over the Congo (Williams and Stanfill, 2002). The CPR model suggested by Meijer et al. (2001) is now used with ten times higher lightning yields over land than over ocean (Boersma et al., 2005).

Kurz and Grewe (2002) compare the flash frequencies from the global circulation model E39/C using either the CTH or UPD model with those from OTD. The UPD version computes a land/sea flash ratio of 3.1 which is below the value of 6 derivable from OTD data (Kurz and Grewe, 2002) but far better than the ratio of 160 which would result for the same land/sea mask when using the same CTH flash parameterisation for ocean as for land globally. Kurz (2006) applies the UPD model for comparison with TROCCINOX data. He finds that the IC/CG ratio is not important in this approach because of prescribed total $\mathrm{LNO}_{\mathrm{x}}$ source and given vertical emission profiles. For IC/CG ratios of 0.1 and 1 the concentrations over the continental tropics differ by less than $3 \%$. The comparison with TROCCINOX observations shows that the UPD parameterisation reproduces the observed variability of convection and the related $\mathrm{NO}_{\mathrm{x}}$ fields far better than the CTH model, see Fig. 22. The model computed CTH values are often rather uniform in that most cloud tops reach close to the tropopause while updraft speed (and precipitation) varies more strongly.

Choi et al. (2005) use a regional chemical transport model with various lightning parameterisations. They find best agreement with ground-based lightning observations when using a combination of UPD and CAPE, but with different parameterisations for land and ocean. Correlations between CAPE and aerosols with lightning have been investigated with observed data over the Amazon by Williams et al. (2002). More recently, precipitating ice mass has been suggested as indicator of lightning activity (Petersen et al., 2005; Gauthier et al., 2006; Sherwood et al., 2006). Also an elevated cloud base height has been identified to support transfer of CAPE to updraft energy in thunderstorms causing strong updrafts, high lightning flash rates and high lightning yields (Williams and Stanfill, 2002; Williams et al., 2005; Jayaratne and Kuleshov, 2006). However, these parameters are not yet included in predictive models.

\subsubsection{Cloud scale models}

Cloud-scale models have been used to simulate the transport and distribution of $\mathrm{NO}_{\mathrm{x}}$, and its contribution to photochemistry at scales directly comparable to airborne measurements in thunderstorm systems (Hauf et al., 1995; Thompson et al., 1997; Pickering et al., 1998; Marécal et al., 2006; Rivière et al., 2006). Cloud-scale models parameterise flash occur- rence, flash position, and related $\mathrm{LNO}_{\mathrm{x}}$ sources inside the cloud as a function of pressure (Wang et al., 1998a; DeCaria et al., 2000), temperature, model hydrometeor fields (DeCaria et al., 2000, 2005; Ott et al., 2007), updraft speed and thickness of the "cold" cloud region between the $0^{\circ} \mathrm{C}$ isotherm and cloud top (Price and Rind, 1993; Fehr et al., 2004), or cloud top height and thickness of cold cloud regions (Price and Rind, 1992; Mari et al., 2006). The flashspecific $\mathrm{LNO}_{\mathrm{x}}$ production rate and the relative contributions from IC and CG flashes are free parameters in these models. Only a few models simulate the process of charge separation and lightning discharges when reaching critical electric field strengths (Takahashi, 1984; Wang and Prinn, 2000; Zhang et al., 2003b; Barthe et al., 2005; Fierro et al., 2006; Kuhlman et al., 2006; Barthe and Pinty, 2007). The simulated storm charge structure depends strongly on the choice of charging parameterisation, breakdown assumptions and flash parameterisation (Kuhlman et al., 2006; Barthe and Pinty, 2007). A detailed review of the methods used for this purpose is beyond the scope of the paper. The model quality is assessed by comparing simulated cloud and lightning field properties and $\mathrm{NO}_{\mathrm{x}}$ concentrations with observations. Such studies have been performed with 2-D and 3-D cloud-scale models for the measurements during STERAO (DeCaria et al., 2000; Skamarock et al., 2000, 2003; DeCaria et al., 2005; Barthe et al., 2007), with 3-D models for EULINOX (Fehr et al., 2004; Ott et al., 2007), and with 3-D models for TROCCINOX (Chaboureau and Bechtold, 2005; Chaboureau et al., 2007; Mari et al., 2006). By fitting the model results to mainly airborne observations, the results provide insight on the effective transports and emission profiles, and on the air chemistry induced by $\mathrm{LNO}_{\mathrm{x}}$ from the thunderstorm. The results can be used to derive both the flash-specific $\mathrm{LNO}_{\mathrm{x}}$ production rate and the relative contributions from IC and CG flashes. Some results with estimates of the $\mathrm{LNO}_{\mathrm{x}}$ production per flash and per thunderstorm, and the IC/CG $\mathrm{LNO}_{\mathrm{x}}$ productivity ratio, are reported in Sects. 3.1 and 3.2.

\subsection{Climate impact of $\mathrm{LNO}_{\mathrm{x}}$}

In a future warmer world, more thunderclouds may form, causing more lightning, more $\mathrm{LNO}_{\mathrm{x}}$ production, and hence, larger $\mathrm{O}_{3}$ concentrations, stronger radiative forcing, which may intensify the warming and thus produce more thunderstorms. Therefore, though still under debate (Williams, 2005; Harrison, 2006), $\mathrm{LNO}_{\mathrm{x}}$ may contribute to a positive climate feedback cycle (Williams, 1992).

$\mathrm{LNO}_{\mathrm{x}}$ contributes with a positive radiative forcing on climate via ozone formation in the upper troposphere (Toumi et al., 1996; Sinha and Toumi, 1997) and a negative forcing by enhanced $\mathrm{OH}$ reducing $\mathrm{CH}_{4}$ (Isaksen and Hov, 1987). For a $\mathrm{LNO}_{\mathrm{x}}$ increase from 3-6 $\mathrm{Tg} \mathrm{a}^{-1}$, Martin et al. (2002b) compute a $10 \%$ increase in $\mathrm{OH}$ and a reduction of the lifetime of methyl chloroform $\left(\mathrm{CH}_{3} \mathrm{CCl}_{3}\right)$ from 5.9 to 5.3 years. Labrador et al. (2004) calculate $\mathrm{OH}$ increases by $10 \%$ and 
$23 \%$ when the global lightning source is increased, respectively, by a factor of 2 and 4 from a $5 \mathrm{Tg} \mathrm{a}^{-1}$ reference case. A 1.4 years difference in $\mathrm{CH}_{4}$ lifetime is found for $\mathrm{LNO}_{\mathrm{x}}$ varying from 3 to $8 \mathrm{Tg} \mathrm{a}^{-1}$ (Wild, 2007). Fiori et al. (2006) compute that the $\mathrm{CH}_{4}$ lifetime decreased by $1.6 \%$ from 1991-1995 to 2000-2004, reflecting increases in $\mathrm{OH}$ and temperature due to increasing $\mathrm{LNO}_{\mathrm{x}}$.

Ozone in the upper troposphere has a larger impact on the radiative forcing of the atmosphere than ozone generated near the Earth surface because of lower ambient temperatures and smaller optical depth of the air mass above that level (Chalita et al., 1990; Lacis et al., 1990; Strand and Hov, 1994; Hansen et al., 2005). This is one of the reasons why $\mathrm{NO}_{\mathrm{x}}$ emissions into the upper troposphere have a far larger climate impact than $\mathrm{NO}_{\mathrm{x}}$ emissions at the surface (Johnson et al., 1992). Using a 2-D global model, Toumi et al. (1996) find that a $20 \%$ increase in lightning (from 5 to $6 \mathrm{Tg} \mathrm{a}^{-1}$ ) enhances the global mean radiative forcing via tropospheric $\mathrm{O}_{3}$ by about $0.1 \mathrm{~W} \mathrm{~m}^{-2}$. Hopkins (2003) computes a smaller sensitivity: the global average total radiative forcing due to $\mathrm{O}_{3}$ formed by $6.5 \mathrm{Tg} \mathrm{a}^{-1}$ of $\mathrm{LNO}_{\mathrm{x}}$ is about $0.1 \mathrm{~W} \mathrm{~m}^{-2}$ in her model.

Positive correlations between surface temperature, lightning activity, and the global electric circuit have been identified from observations at daily to interannual time scales (Williams, 1992; Harrison, 2004; Williams, 2005). The amplitude of the Schumann resonance oscillations in the ground-ionospheric cavity (Schumann, 1952; Rycroft et al., 2000; Price et al., 2007) and temperature fluctuations in the tropical atmosphere are positively correlated mainly because of lightning activity increasing with temperature (Williams, 1992). For a $1 \%$ increase in global surface temperature, the ionospheric potential may increase by $20 \%(\sim 50 \mathrm{kV})$ (Price, 1993). An increase in global lightning of 5-6\% per degree Kelvin global warming was derived (Price and Rind, 1994a; Satori and Zieger, 1996), with much larger regional and temporal changes. Finally, biomass burning is likely to increase with climate change as a result of increased lightning-caused fires (Price and Rind, 1994b).

Correlations between observed lightning and temperature seem to support the existence of a lightning-climate interaction: For example, a seasonal sensitivity of the flash frequency to surface temperature of $50-800 \% \mathrm{~K}^{-1}$ was found (Williams, 1994); the sensitivity increases with decreasing latitude. The global position of lightning activity shifts with El Niño and La Niña (Satori and Zieger, 1996). Satellitederived intraseasonal oscillations in deep convection modulate the global variations in the Schumann resonance intensity (Anyamba et al., 2000). The correlation of OTD flash data with monthly mean wet-bulb temperature anomalies is strongest in the Northern Hemisphere and weak in the Southern Hemisphere, and a change in the average land wet-bulb temperature of $1 \mathrm{~K}$ may result in a change in lightning activity of about $40 \pm 14 \%$ (Reeve and Toumi, 1999). Over the Gulf of Mexico, during the 1997-1998 El Niño event, a 100-150\% increase in lightning days is found, compared to the 1996-1997 and 1998-1999 winters, apparently correlated with increase in synoptic scale cyclones and the position and strength of the jet stream (Goodman et al., 2000). The 5-year LIS data, the 8-year OTD data, and the NCEP reanalysis data of surface air temperature show a sensitivity of lightning to temperature of up to $17 \pm 7 \% \mathrm{~K}^{-1}$, but the correlation varies with latitude, land/ocean regions, and periods (Ma et al., 2005).

Further evidence supports the existence of a lightningclimate interaction: The upper tropospheric water vapour variability, upper tropical cloud coverage, and the global lightning activity are closely linked, because continental deep convective thunderstorms transport large amounts of water vapour into the upper troposphere while producing most of the lightning on Earth (Price, 2000; Price and Asfur, 2006). Using TRMM lightning and radar data, a strong relationship is found between precipitating ice mass and lightning flash density (Petersen et al., 2005). Durden et al. (2004) find high correlation between average flash rates and precipitation data from satellites over both land and ocean; although both flash rates and radar reflectivity are much lower over ocean than land. In contrast, the anomalies of lightning and precipitation have different spatial patterns; however, both are correlated with the Southern Oscillation Index and, hence, El Niño. Differences in behaviour of the lightning and precipitation anomaly correlations suggest that El Niño plays a smaller role in lightning anomaly than precipitation anomaly.

Several model studies identify an increase in lightning and $\mathrm{LNO}_{\mathrm{x}}$ emissions due to global warming, see Table 14 . The estimates of $\mathrm{LNO}_{\mathrm{x}}$ increases due to global warming vary within $4-60 \% \mathrm{~K}^{-1}$ with median near $15 \% \mathrm{~K}^{-1}$. Some studies find no global trend in lightning emissions over the period 1990-2030, but significant changes in its distribution (Stevenson et al., 2005; Sanderson et al., 2006). Another study finds large interannual variability of the $\mathrm{LNO}_{\mathrm{x}}$ source $\left(5.2 \pm 0.3 \mathrm{Tg} \mathrm{a}^{-1}\right)$ but no significant trend in a transient simulation with the interactively coupled chemistry-climate model (CCM) E39/C over the 40-year period 1960 to 1999 (Dameris et al., 2005). Larger changes over the coming century are not excluded with these results. Models also compute a correlation between the El Niño phenomenon and the ozone column (Doherty et al., 2006). Lightning occurrence and $\mathrm{LNO}_{\mathrm{x}}$ emissions increase during El Niño periods and leads to an inter-annual ozone variability of around $3 \%$ in the tropical upper troposphere (Grewe, 2007).

For a possible global warming of 1.5 to $5.8 \mathrm{~K}$ (IPCC, 2001), a $\mathrm{LNO}_{\mathrm{x}}$ increase of $15 \% \mathrm{~K}^{-1}$ would imply a 20 $90 \%$ increase in lightning activity. Hence, future changes in $\mathrm{LNO}_{\mathrm{x}}$ emissions may be larger than future increases in aviation $\mathrm{NO}_{\mathrm{x}}$ emissions (see Sect. 2.9). On the other hand, future $\mathrm{O}_{3}$ increases from increased $\mathrm{LNO}_{\mathrm{x}}$ and other emissions are partially damped by increased tropospheric water vapour concentration (Brasseur et al., 2006). 
Table 14. Lightning sensitivity to global warming in model computations.

\begin{tabular}{|c|c|c|c|c|c|c|}
\hline Model & Period & Parameter & $\begin{array}{l}\mathrm{LNO}_{\mathrm{x}}, \\
\mathrm{Tg} \mathrm{a}^{-1}\end{array}$ & $\begin{array}{l}\Delta \mathrm{T}, \\
\mathrm{K}\end{array}$ & $\begin{array}{l}\text { Relative } \\
\text { change, } \\
\% \mathrm{~K}^{-1}\end{array}$ & Reference \\
\hline GISS & $2 \times \mathrm{CO}_{2}$ & Flash frequency & - & 4.2 & $5-6$ & Price and Rind (1994a) \\
\hline Global 2-D model & $\begin{array}{l}2 \mathrm{~K} \text { warming pe- } \\
\text { riod }\end{array}$ & $\mathrm{LNO}_{\mathrm{x}}$ & 5 & 2 & 10 & Toumi et al. (1996) \\
\hline ARPEGE & $2 \times \mathrm{CO}_{2}$ & Flash frequency & - & 2 & 5 & Michalon et al. (1999) \\
\hline GISS GCM & $\sim 1860-2000$ & $\mathrm{LNO}_{\mathrm{x}}$ & $3.6-3.9$ & 1.8 & 4 & Shindell et al. (2001) \\
\hline $\mathrm{E} 39 / \mathrm{C}$ & $1992-2015$ & $\mathrm{LNO}_{\mathrm{x}}$ & $5.4-5.9$ & $\sim 1$ & 9 & Grewe et al. (2002) \\
\hline 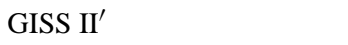 & $1860-2000$ & $\mathrm{LNO}_{\mathrm{x}}$ & $6.2-6.5$ & $\sim 0.5$ & $\sim 10$ & Shindell et al. (2003) \\
\hline $\begin{array}{l}\text { GISS ( } 23 \text { layers, with chem- } \\
\text { istry) }\end{array}$ & $2 \times \mathrm{CO}_{2}$ & $\mathrm{LNO}_{\mathrm{x}}$ & 6.5 & & $22-27$ & Hopkins (2003) \\
\hline GISS & $2000-2100$ & $\mathrm{LNO}_{\mathrm{x}}$ & $4.9-6.9$ & 3.25 & 12 & Grenfell et al. (2003) \\
\hline ECHAM/CHEM & $1960-2105$ & $\mathrm{LNO}_{\mathrm{x}}$ & $5.1-5.6$ & 0.7 & 14 & Stenke and Grewe (2004) \\
\hline GISS $1 / 2$ & $2000-2100$ & $\mathrm{LNO}_{\mathrm{x}}$ & $6-13.5$ & $\sim 2$ & $\sim 60$ & Lamarque et al. (2005) \\
\hline NCAR (CAM, MOZART) & $2000-2100$ & $\mathrm{LNO}_{\mathrm{x}}$ & $2.2-2.8$ & $\sim 2$ & $\sim 14$ & Lamarque et al. (2005) \\
\hline LMDz/INCA & $2000-2100$ & $\mathrm{LNO}_{\mathrm{x}}$ & $5-7.5$ & 2.45 & 22 & Hauglustaine et al. (2005) \\
\hline $\mathrm{E} 39 / \mathrm{C}$ & 1969-1999 & $\mathrm{LNO}_{\mathrm{x}}$ & $5.2 \pm 0.3$ & $0.5-1$ & - & Dameris et al. (2005) \\
\hline HadAM3-STOCHEM & 1990-2030 & $\mathrm{LNO}_{\mathrm{x}}$ & 7 & & - & Stevenson et al. (2005) \\
\hline MOZART 2/NCAR-CSM & $2000-2100$ & $\mathrm{LNO}_{\mathrm{x}}$ & $3.9-4.5$ & $\sim 2$ & $\sim 15$ & Murazaki and Hess (2006) \\
\hline GISS III (G-PUCCINI) & $2000-2100$ & $\mathrm{LNO}_{\mathrm{x}}$ & $5.2-7.2$ & $\sim 3$ & $\sim 13$ & Shindell et al. (2006) \\
\hline GISS III & $2000-2030$ & $\mathrm{LNO}_{\mathrm{x}}$ & $6.2-6.5$ & 0.68 & 7 & Unger et al. (2006) \\
\hline MOZART 2 with ECHAM5 & $2000-2100$ & $\mathrm{LNO}_{\mathrm{x}}$ & $\sim 3-4$ & $\sim 2.3$ & 9 & Brasseur et al. (2006) \\
\hline
\end{tabular}

2.9 Assessment of aviation $\mathrm{NO}_{\mathrm{x}}$ for uncertain $\mathrm{LNO}_{\mathrm{x}}$ sources

Besides lightning and upward transport from polluted boundary layers over continents by convection, and small contributions from the stratosphere, aviation contributes to $\mathrm{NO}_{\mathrm{x}}$ in the upper troposphere; see Fig. 23 and Table 2. Downward transport of $\mathrm{NO}_{\mathrm{y}}$ (with small $\mathrm{NO}_{\mathrm{x}}$ fraction) (Lee et al., 1997; Martin et al., 2006) from the stratosphere into the upper troposphere occurs mainly near the subtropical jet (Grewe and Dameris, 1996; Lamarque et al., 1999), and possibly by sedimentation of cloud particles in polar regions (Weller et al., 2002). The amount and distribution of $\mathrm{NO}_{\mathrm{x}}$ emissions from aviation is known to about $\pm 15 \%$ accuracy (Schumann et al., 2001). Hence, the aviation $\mathrm{NO}_{\mathrm{x}}$ source is far better known than most other $\mathrm{NO}_{\mathrm{x}}$ emissions. Aviation $\mathrm{NO}_{\mathrm{x}}$ emissions grew from about 0.55 to $0.7 \mathrm{Tg} \mathrm{a}^{-1}$ in the years 1992 to 2002 and may double in the next 20 years (Lee et al., 1997; Brasseur et al., 1998a; IPCC, 1999; Eyers et al., 2005). Aircraft $\mathrm{NO}_{\mathrm{x}}$ contributions are clearly detectable in measurements at various scales (Schlager et al., 1999; Schumann et al., 2000; Thompson et al., 2000b). Only a small fraction of $\mathrm{NO}_{\mathrm{x}}$ is oxidised in the exhaust plume in the first $30 \mathrm{~min}$ (Schlager et al., 1997). Aviation $\mathrm{NO}_{\mathrm{x}}$ sources, though smaller than $\mathrm{LNO}_{\mathrm{x}}$ sources globally (see Table 2), may be larger than the $\mathrm{LNO}_{\mathrm{x}}$ source regionally, e.g. over Europe (Huntrieser et al., 2002). Hence, aviation $\mathrm{NO}_{\mathrm{x}}$ contributes significantly to the upper tropospheric $\mathrm{NO}_{\mathrm{x}}$ concentrations at northern midlatitudes and may have considerable influence

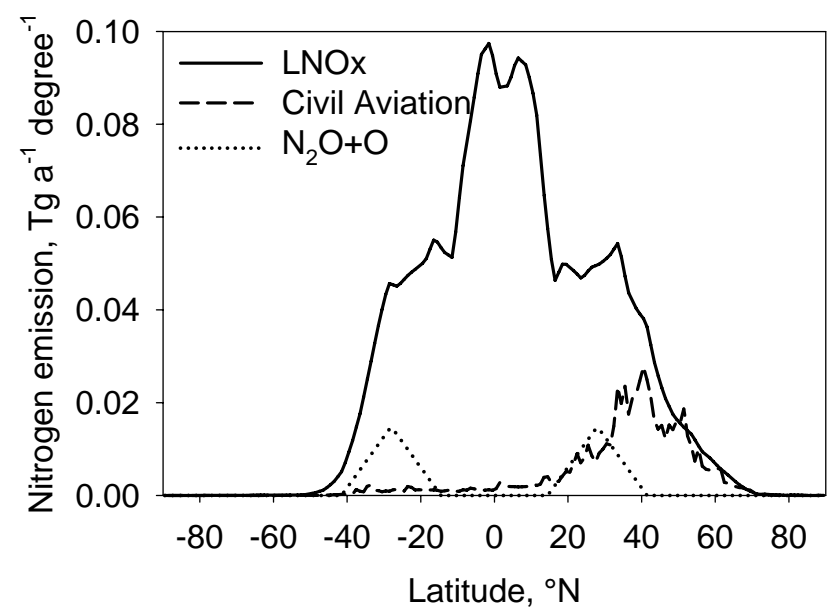

Fig. 23. Annual nitrogen mass emissions from $\mathrm{LNO}_{\mathrm{x}}\left(5 \mathrm{Tg} \mathrm{a}^{-1}\right.$, as in Fig. 2), civil aviation $\left(0.7 \mathrm{Tg} \mathrm{a}^{-1}\right.$, derived from the AERO2K data set (Eyers et al., 2005)), and from degradation of dinitrogen oxide $\left(\mathrm{N}_{2} \mathrm{O}\right)$ by reactions with atomic oxygen in the stratosphere (about $0.4 \mathrm{Tg} \mathrm{a}^{-1}$ ) with a distribution similar to the stratosphere to troposphere mass flux (Grewe and Dameris, 1996).

on $\mathrm{O}_{3}$ and the related radiative forcing (IPCC, 1999; Sausen et al., 2005).

The uncertainty in $\mathrm{LNO}_{\mathrm{x}}$ and its pathways has a significant impact on the assessment of aviation $\mathrm{NO}_{\mathrm{x}}$ contributions in the upper troposphere at midlatitudes in summer (Beck et 
al., 1992). For an increase in $\mathrm{LNO}_{\mathrm{x}}$ from 2 to $10 \mathrm{Tg} \mathrm{a}^{-1}$, the aviation $\mathrm{NO}_{\mathrm{x}}$ share decreases from about $40 \%$ to $20 \%$ (Brasseur et al., 1996; Lamarque et al., 1996; Meijer et al., 2000). Lower emissions from lightning (2 instead of $5 \mathrm{Tg} \mathrm{a}^{-1}$ ) may cause $50-70 \%$ higher enhancement of $\mathrm{O}_{3}$ due to aircraft at northern midlatitudes in summer (Berntsen and Isaksen, 1999). Grewe et al. (2002) find that the replacement of the CTH parameterisation (Price and Rind, 1993) by one based on UPD (Grewe et al., 2001) for the same total $\mathrm{LNO}_{\mathrm{x}}$ rate $\left(5.4 \mathrm{Tg} \mathrm{a}^{-1}\right)$ together with changes in the vertical profile of emissions reduces the aircraft contribution to the upper tropospheric $\mathrm{NO}_{\mathrm{x}}$ content in the Northern Hemisphere from $30 \%$ to $20 \%$, and reduces the aviation-induced net $\mathrm{O}_{3}$ production rate in the region $20^{\circ} \mathrm{N}-70^{\circ} \mathrm{N}, 500-200 \mathrm{hPa}$ by $25 \%$. $\mathrm{LNO}_{\mathrm{x}}$ must also be well known for assessing the impact of aviation $\mathrm{NO}_{\mathrm{x}}$ in the lower and lowermost stratosphere because of transport of $\mathrm{LNO}_{\mathrm{x}}$ from the upper tropical troposphere (Kotamarthi et al., 1994; Grewe et al., 2004). In addition, the impact of supersonic aircraft's $\mathrm{NO}_{\mathrm{x}}$ emissions on the ozone layer may be sensitive to the $\mathrm{LNO}_{\mathrm{x}}$ source (Smyshlyaev et al., 1999).

\subsection{Required $\mathrm{LNO}_{\mathrm{x}}$ accuracy}

The required relative accuracy $\Delta G / G$ of the global $\mathrm{LNO}_{\mathrm{x}}$ source $G$ depends on the parameter $y$ considered, its required relative accuracy $\Delta y / y$, and the sensitivity $\partial y / \partial G$ or the relative contribution $\alpha=(G \partial y / \partial G) / y$ of $G$ to $y$ for which $\Delta y / y=\alpha \Delta G / G$. Consequently,

$\Delta G / G=(\Delta y / y) / \alpha$.

This simple relationship assumes that all other parameters are known. The required relative accuracy $\Delta y / y$ depends on the implications of the result $y$ and is assumed to be $10 \%$ here, without further argument. The required absolute accuracy $\Delta G$ also depends on the best-estimate of the $\mathrm{LNO}_{\mathrm{x}}$ source which is assumed to amount to $G=5 \mathrm{Tg} \mathrm{a}^{-1}$. The sensitivity $\partial y / \partial G$ or the relative contribution $\alpha$ can be determined from detailed model results or from rough estimates, see below. With these parameters the required accuracy of $\mathrm{LNO}_{\mathrm{x}}$ can be estimated as listed in Table 15 and as explained next:

1. For $G=5 \mathrm{Tg} \mathrm{a}^{-1}$, lightning contributes about $60 \%$ to the $\mathrm{NO}_{\mathrm{x}}$ concentrations in the free tropical troposphere, e.g. Brasseur et al. (1996), so that $\alpha=0.6$.

2. For $G=5 \mathrm{Tg} \mathrm{a}^{-1}$, lightning contributes about $\alpha=20 \%$ to the $\mathrm{NO}_{\mathrm{x}}$ concentrations at upper tropospheric midlatitudes (Brasseur et al., 1996).

3. For $5 \mathrm{Tg} \mathrm{a}^{-1}, \mathrm{LNO}_{\mathrm{x}}$ contributes about $30 \%$ to the $\mathrm{O}_{3}$ concentrations in the free tropical troposphere (Brasseur et al., 1996), so that $\alpha=0.3$.

4. The radiative forcing due to tropospheric $\mathrm{O}_{3}$ increase is sensitive to $\mathrm{LNO}_{\mathrm{x}}$ such that a doubling of the source causes an increase of the radiative forcing by about $\alpha=20 \%$ (Toumi et al., 1996).

5. The $\mathrm{OH}$ concentration changes by about $10 \%$ for an increase of $G$ from 5 to $10 \mathrm{Tg} \mathrm{a}^{-1}$ (Labrador et al., 2004). Hence, $\alpha=0.1$.

6. Also, the radiative forcing due to $\mathrm{CH}_{4}$ changes about linearly with the lifetime of $\mathrm{CH}_{4}$ and hence with the $\mathrm{OH}$ concentration, hence, $\alpha=0.1$, as before.

7. The aviation contribution to midlatitude upper tropospheric $\mathrm{NO}_{\mathrm{x}}$ concentration changes from $40 \%$ to $20 \%$ for an increase of $G$ from 2 to $10 \mathrm{Tg} \mathrm{a}^{-1}$ (Lamarque et al., 1996). Hence, $\alpha=0.125$.

8. The feedback of lightning on climate may increase $\mathrm{LNO}_{\mathrm{x}}$ by $50 \%$ (Hauglustaine et al., 2005), the radiative forcing by about $0.1 \mathrm{~W} \mathrm{~m}^{-2}$ (Toumi et al., 1996), and the temperature increase over the next century by about $5-10 \%$ ( 0.2 of $2 \mathrm{~K}$ ) (IPCC, 2001), implying $\alpha=0.1$ to 0.2 .

9. $\mathrm{LNO}_{\mathrm{x}}$ contributions to acid rain are small in most regions, but may reach about $\alpha=20 \%$ in the tropics (Bond et al., 2002), see Table 2.

10. Acid rain over the industrialised countries is affected by $\mathrm{LNO}_{\mathrm{x}}$ to about $\alpha=5 \%$ (Zhang et al., 2003a), see also Table 2.

This simple exercise tells us that the accuracy is most important for assessing the $\mathrm{NO}_{\mathrm{x}}$ concentration in the tropics, for assessing tropical $\mathrm{O}_{3}$ and the radiative forcing from tropospheric $\mathrm{O}_{3}$, and possibly for assessing acid rain in the tropics. For these purposes, the $\mathrm{LNO}_{\mathrm{x}}$ value should be known to about $1 \mathrm{Tg} \mathrm{a}^{-1}$ or about $20 \%$. On the other hand, an accuracy of about $5 \mathrm{Tg} \mathrm{a}^{-1}$ (100\%) should be sufficient for the other listed parameters.

At present, the accuracy of observations and models restricts the achievable accuracy to about $50 \%$, as explained in Sect. 3.3.5. The interannual variability of global lightning may restrict the practically achievable accuracy of the annual mean global $\mathrm{LNO}_{\mathrm{x}}$ source to about $5 \%$. For regional applications, not only the global budget but also the regional $\mathrm{LNO}_{\mathrm{x}}$ distribution must be simulated with comparable accuracy.

\section{Methods to constrain the $\mathrm{LNO}_{\mathrm{x}}$ values}

The methods which have been used to estimate the global $\mathrm{LNO}_{\mathrm{x}}$ source rate are summarised in Table 16. This chapter describes the various approaches and identifies their limitations and possible extensions. 
Table 15. $\mathrm{LNO}_{\mathrm{x}}$ sensitivity and required accuracy of the $\mathrm{LNO}_{\mathrm{x}}$ source $G$.

\begin{tabular}{|c|c|c|c|c|}
\hline No. & Parameter & $\alpha, \mathrm{LNO}_{\mathrm{x}}$ Contribution in $\%$ & $\Delta G / G, \%$ & $\Delta G^{*}, \operatorname{Tg~a}^{-1}$ \\
\hline 1) & $\mathrm{NO}_{\mathrm{x}}$ concentration in the free tropical troposphere & 60 & 17 & 0.8 \\
\hline 2) & $\mathrm{NO}_{\mathrm{x}}$ concentration in upper mid-latitudinal troposphere & 20 & 50 & 2.5 \\
\hline 3) & Ozone concentration in the tropical troposphere & 30 & 33 & 1.7 \\
\hline 4) & Radiative forcing by tropospheric $\mathrm{O}_{3}$ & 20 & 50 & 2.5 \\
\hline 5) & $\mathrm{OH}$ concentration & 10 & 100 & 5.0 \\
\hline 6) & Lifetime of $\mathrm{CH}_{4}$ and related radiative forcing & 10 & 100 & 5.0 \\
\hline 7) & Relative importance of aviation $\mathrm{NO}_{\mathrm{x}}$ contribution & 12.5 & 80 & 4.0 \\
\hline 8) & Temperature increase from climate feedback of lightning & 20 & 50 & 2.5 \\
\hline 9) & Acid rain rate over tropical continents & 20 & 50 & 2.5 \\
\hline 10) & Acid rain rate over the industrialised countries & 5 & 200 & 10.0 \\
\hline
\end{tabular}

* Absolute accuracy computed from $\Delta G / G$ for $G=5 \mathrm{Tg} \mathrm{a}^{-1}$.

\subsection{Flash extrapolation}

The flash extrapolation method determines the global $\mathrm{LNO}_{\mathrm{x}}$ production rate as the product of the $\mathrm{LNO}_{\mathrm{x}}$ production rate per flash and the global flash frequency (Lawrence et al., 1995). The $\mathrm{LNO}_{\mathrm{x}}$ production rate per flash may be determined from the production rate per discharge unit energy (or peak current (Wang et al., 1998a)) times the discharge energy (or peak current) per lightning flash, e.g. from theoretical considerations, from laboratory experiments, or from observations in the atmosphere. Alternative approaches determine the flash-length-specific production rate and then multiply the result with length estimates. Other approaches determine the $\mathrm{LNO}_{\mathrm{x}}$ production rate directly per flash. All these approaches assume that one set of flash property values is representative for all flashes occurring globally. The production rate per flash is usually expressed in number of molecules or moles or mass, where $6.02 \times 10^{23}$ molecules $=1 \mathrm{~mol}=14 \mathrm{~g}$ of nitrogen.

\subsection{1 $\mathrm{LNO}_{\mathrm{x}}$ production per flash energy or peak current}

Published estimates for the energy-specific $\mathrm{LNO}_{\mathrm{x}}$ production rates are listed in Table 17; for studies published before 1988 see Lawrence et al. (1995). The values range within 1$50 \times 10^{16}$ molecules $\mathrm{J}^{-1}$. The upper bound value seems a bit high, because if all discharge energy is consumed to split the triple bond of molecular nitrogen $\left(0.94 \mathrm{MJ} \mathrm{mol}^{-1}\right)$ the $\mathrm{LNO}_{\mathrm{x}}$ production could reach at most $64 \times 10^{16}$ molecules $\mathrm{J}^{-1}$.

The flash discharge energy that is spent in ionisation of the air in the flash channel, shock-wave channel expansion, and the production of electromagnetic (including optical) and acoustic radiation from the flash channel may be estimated from theoretical considerations (Tuck, 1976), from acoustical energy of thunders (Hameed et al., 1981), or from comparisons of measured optical energies in natural lightning first strokes with laboratory spark experiments (Orville, 1968; Rakov and Uman, 2003). The stroke energy $E=1 / 2$
QV depends on the charge Q (in Coulombs) transferred and the total potential V (in Volts) (Bradshaw, 1996). The peak current $\mathrm{I}=\mathrm{Q} / \Delta \mathrm{t}$ (in Ampere) in the stroke depends on the charge transferred and the stroke duration $\Delta \mathrm{t}$. For typical values (Uman, 1987; Orville et al., 2002), V=10 MV, $\mathrm{I}=20 \mathrm{kA}, \Delta \mathrm{t}=1 \mathrm{~ms}$, we compute $\mathrm{Q}=20 \mathrm{C}$, and $\mathrm{E}=0.1 \mathrm{GJ}$. Early studies estimated the energy of an average lightning stroke as about $10 \mathrm{GJ}$ (Vonnegut, 1963). From field and laboratory experimental data, a length specific discharge energy of $230 \mathrm{~kJ} \mathrm{~m}^{-1}$ for a single return-stroke natural flash was derived (Krider et al., 1968). A review of estimates from electrical, optical, acoustical and theoretical methods revealed a value of $10 \mathrm{~kJ} \mathrm{~m}^{-1}$ (Hill, 1979). From electrostatic consideration, a possible range of length specific values between 100 and $1000 \mathrm{~kJ} \mathrm{~m}^{-1}$ was deduced (Uman, 1987), while Cooray (1997) computes $70 \mathrm{~kJ} \mathrm{~m}^{-1}$. For $5 \mathrm{~km}$ flash length, these values imply a range of 0.35 to 5 GJ per stroke. Recent field measurements find even far smaller energies between 1 and $10 \mathrm{~kJ} \mathrm{~m}^{-1}$ in rocket-triggered lightning (Jayakumar et al., 2006). However, a natural flash may differ from rocket triggered ones. Moreover, a single flash usually includes several strokes. A best estimate value of about $0.4 \mathrm{GJ}$ per flash, with uncertainty factor of about 3 was derived from reanalysis of several optical and electrical measurements by Borucki and Chameides (1984), assuming 1.75 equivalent return strokes per flash. Also Bradshaw (1996) reviewed the interpretation of previous experimental data and derived energies per lightning flash of $1.2 \mathrm{GJ}$ for midlatitude negative $\mathrm{CG}$ lightning $\left(240 \mathrm{~kJ} \mathrm{~m}^{-1}\right)$ and similar values for other flash types: $2.3 \mathrm{GJ}$ for tropical negative CG lightning, 3 GJ for positive CG lightning and $0.9 \mathrm{GJ}$ for IC lightning with uncertainties of at least a factor of 2. Far larger discharge energy values, 6.7 GJ per flash, were derived from a review of observations and the contributions of lightning to the global atmospheric electric circuit (Price et al., 1997a, b). Hence, the flash-specific value of discharge energy derived from these studies ranges within at least 0.4 and $6.7 \mathrm{GJ}$ per flash, with different values depending on flash type. 
Table 16. Methods to derive estimates of the global $\mathrm{LNO}_{\mathrm{x}}$ production rate.

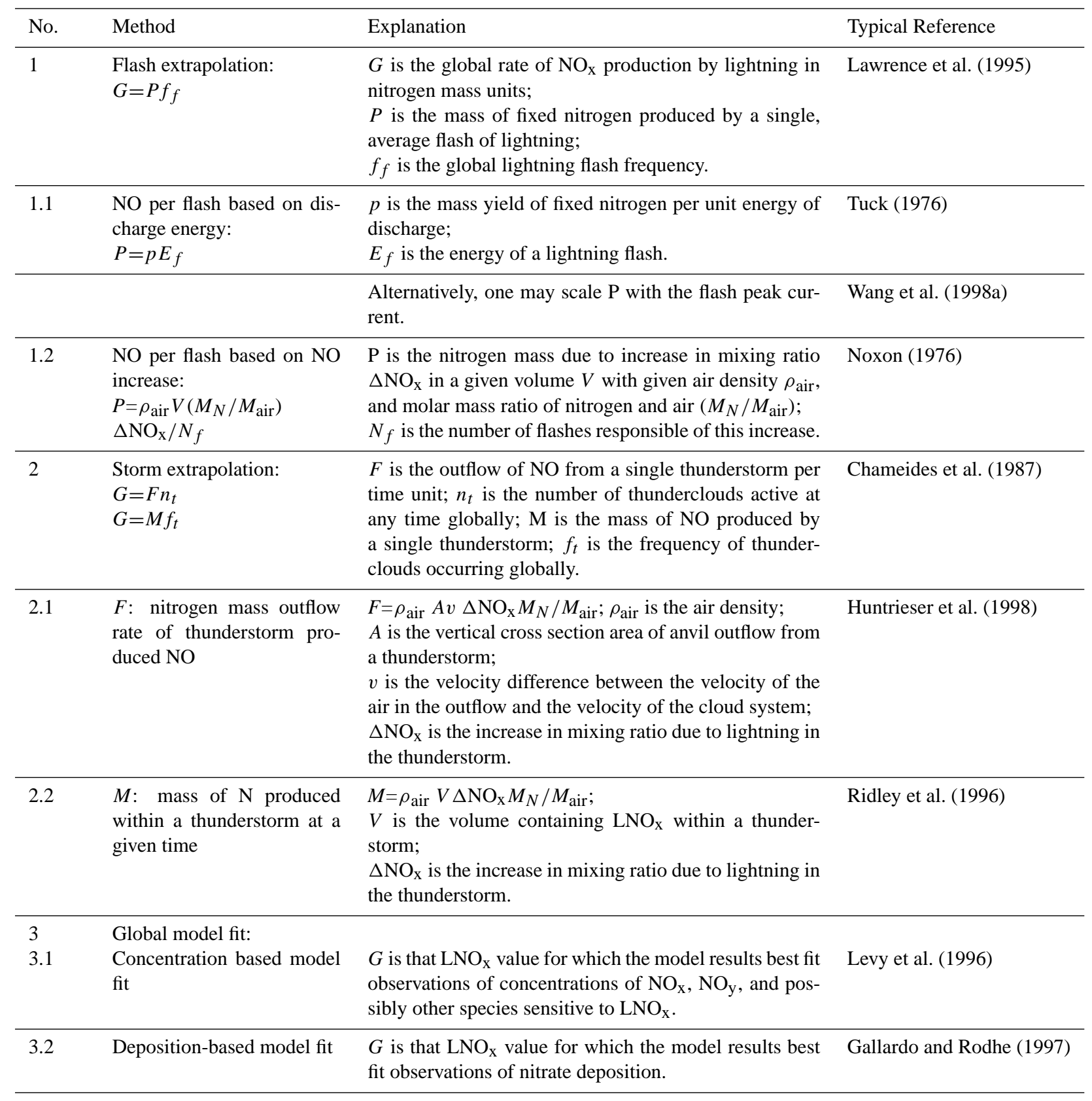

Wang et al. (1998a) pointed out that $\mathrm{LNO}_{\mathrm{x}}$ is not a unique function of the energy converted to heat in the flash discharge but increases (about linearly) with atmospheric pressure and (about quadratically) with the peak current of the flash, see Fig. 24. For surface pressure, the energyspecific NO molecule production was found to increase from $15 \times 10^{16}$ to $40 \times 10^{16} \mathrm{~J}^{-1}$ for an increase in peak current from $10 \mathrm{kA}$ to $30 \mathrm{kA}$. The same flash at $370 \mathrm{hPa}$ would produce half that amount. A quadratic dependence on the peak current $I$ may be expected for constant channel resistance $R$ and stroke duration $\Delta t$, where the energy released in a lightning stroke is $E=1 / 2 R I^{2} \Delta t$. Peak currents in (negative) $\mathrm{CG}$ flashes observed from the ground-based lightning detection systems NLDN are typically 10-30 kA (Orville, 1990; Petersen and Rutledge, 1992; Wacker and Orville, 1999; Orville et al., 2002; Langford et al., 2004). The measured dependence of the NO production as a function of flash peak current and ambient pressure opens a new approach to estimate the $\mathrm{LNO}_{\mathrm{x}}$ production per flash from lightning detection systems identifying flashes and peak currents (Huntrieser et 
Table 17. Lightning $\mathrm{NO}_{\mathrm{x}}$ production rate per discharge energy.

\begin{tabular}{|c|c|c|}
\hline $\begin{array}{l}\text { Production rate, } 10^{16} \\
\text { molecules } \mathrm{J}^{-1}\end{array}$ & Method & Author \\
\hline $1.4 \pm 0.7$ & Laboratory simulated corona discharges & Hill et al. (1988) \\
\hline $8.5 \pm 4.7$ & Review & Lawrence et al. (1995) \\
\hline $9(5-17)$ & Review and lightning data for USA & Biazar and McNider (1995) \\
\hline $\begin{array}{l}7.5(\mathrm{CG}-), 15(\mathrm{CG}+), 5 \\
(\mathrm{IC})\end{array}$ & $\begin{array}{l}\text { Based on a critical review distinguish- } \\
\text { ing negative (CG-) and positive (CG-) } \\
\text { cloud to ground flashes and intracloud } \\
\text { (IC) flashes }\end{array}$ & Bradshaw (1996) \\
\hline $9 \pm 2$ & $\begin{array}{l}\text { Laboratory discharges, } \mathrm{NO} / \mathrm{NO}_{\mathrm{x}} \text { mea- } \\
\text { surements, and literature (Borucki and } \\
\text { Chameides, 1984) }\end{array}$ & Stark et al. (1996) \\
\hline 10 & Theoretical & Price et al. (1997a, b) \\
\hline $10-50$ & Laboratory experiments & Wang et al. (1998a) \\
\hline $1.1 \pm 0.2$ & $\begin{array}{l}\text { Laboratory experiments of low energy } \\
\text { sparks }\end{array}$ & Cook et al. (2000) \\
\hline $15 \pm 5$ & $\begin{array}{l}\text { Lightning in laboratory simulated hot } \\
\text { plasma generated with pulsed Nd-YAG } \\
\text { laser. Initial temperature near } 10^{5} \mathrm{~K} \text {. }\end{array}$ & Navarro-González et al. (2001) \\
\hline $20-30$ & $\begin{array}{l}\text { Laboratory streamer discharges in a coax- } \\
\text { ial cylinder cell }\end{array}$ & Cooray and Rahman (2005) \\
\hline
\end{tabular}

al., 2006). Unfortunately, the satellite systems like OTD identify the flash-energy-related radiances nearly globally (Baker et al., 1999) but not the peak currents of the flashes.

\subsection{2 $\mathrm{LNO}_{\mathrm{x}}$ production per flash length}

Some airborne studies derive the $\mathrm{LNO}_{\mathrm{x}}$ production per unit flash-length from measurements of the concentration of $\mathrm{NO}_{\mathrm{x}}$ in fresh flash plumes near thunderstorms, see Table 18. In order to extrapolate these values to $\mathrm{LNO}_{\mathrm{x}}$ production per flash, one needs to know their lengths. Some authors use typical altitude ranges of 5-7 km for midlatitude CG flashes and 1$6 \mathrm{~km}$ for IC flashes (Price et al., 1997b), but detailed studies of lightning flashes show that flashes may be far longer (Defer et al., 2001; Thery, 2001; Thomas et al., 2004), see Fig. 7. For the STERAO case, the flash length derived from VHF lightning observations and model studies is about 20$30 \mathrm{~km}$ (Defer et al., 2001; Barthe et al., 2007). For the 21 July EULINOX supercell, typical flash lengths for IC and CG flashes derived from VHF lightning and radar observations are: $43 \mathrm{~km}$ for an IC flash, $26.5 \mathrm{~km}$ for a negative CG flash, and $29.5 \mathrm{~km}$ for a positive CG flash (Dotzek et al., 2000). A flash may even have a fractal structure implying that the actual length scales with the height with a power larger than one. A ratio of 3.6 between the effective length of the dis-

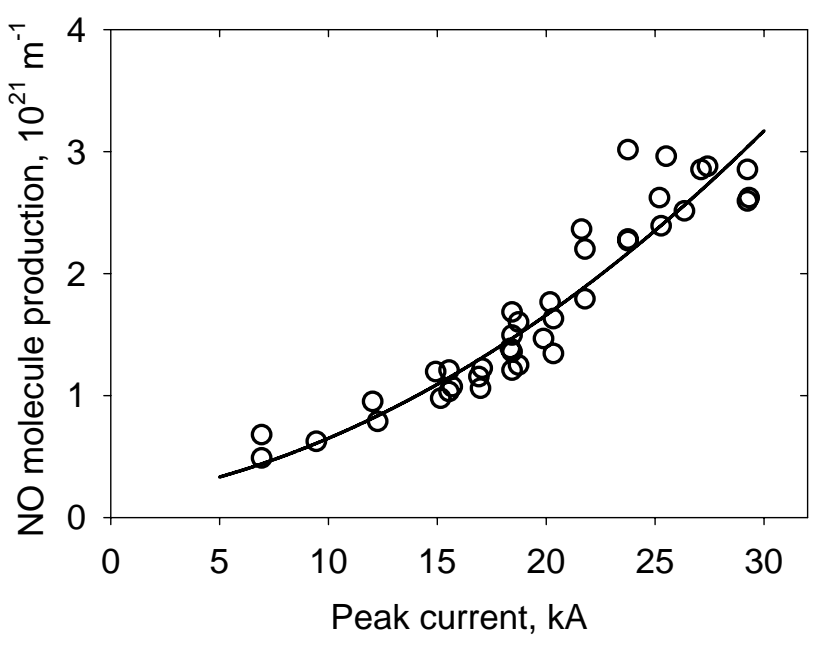

Fig. 24. NO molecules produced per spark length as a function of peak current for ambient surface pressure and temperature; data and quadratic fit; replotted from Wang et al. (1998a).

torted flash and the outer geometrical scale ("tortuosity ratio") has been estimated by Wang et al. (1998a). 
Table 18. Lightning $\mathrm{NO}_{\mathrm{x}}$ production rate per flash length.

\begin{tabular}{|c|c|c|}
\hline $\begin{array}{l}\text { Production rate per flash } \\
\text { length, } 10^{21} \text { molecules } \\
\mathrm{m}^{-1}\end{array}$ & Method & Author \\
\hline $1.4-5.2$ & $\begin{array}{l}\text { Laboratory NO measurements and flash } \\
\text { chemistry model, including a tortuosity } \\
\text { factor of } 3.6 \text { for the flash length }\end{array}$ & Wang et al. (1998a) \\
\hline 13 & $\begin{array}{l}\text { Airborne NO measurements, LINOX, } \\
\text { Germany, } 23 \text { July 1996, and 2-D model, } \\
\text { Lightning Position And Tracking System } \\
\text { (LPATS)/Blitz-Informations-Dienst von } \\
\text { Siemens (BLIDS) }\end{array}$ & Höller et al. (1999) \\
\hline $2.5(0.2-10)$ & $\begin{array}{l}\text { Airborne NO measurements, STERAO, } \\
\text { Colorado, 9-10 July 1996, VHF interfer- } \\
\text { ometer (ONERA), NLDN }\end{array}$ & Stith et al. (1999) \\
\hline $2.7(0.07-10)$ & $\begin{array}{l}\text { Airborne NO measurements, EULINOX, } \\
\text { Germany, } 21 \text { July 1998, VHF interferom- } \\
\text { eter (ONERA) }\end{array}$ & Huntrieser et al. (2002) \\
\hline 1 & $\begin{array}{l}\text { 3-D cloud model, airborne NO measure- } \\
\text { ments, STERAO, North Colorado, } 10 \\
\text { July 1996, VHF interferometer (ONERA) }\end{array}$ & Skamarock et al. (2003) \\
\hline 7.5 & $\begin{array}{l}\text { 3-D cloud model, airborne NO mea- } \\
\text { surements, EULINOX, Germany, } 21 \text { July } \\
\text { 1998, VHF interferometer (ONERA) }\end{array}$ & Ott et al. (2007) \\
\hline
\end{tabular}

Table 19. IC/CG $\mathrm{LNO}_{\mathrm{x}}$ production rate per flash ratio.

\begin{tabular}{lll}
\hline $\mathrm{Z}=\mathrm{P}_{\mathrm{IC}} / \mathrm{P}_{\mathrm{CG}}$ & Method & Author \\
\hline $1 / 3$ & Acoustic measurements & Hameed et al. (1981) \\
0.1 & Review & Kowalczyk and Bauer (1981) \\
$1 / 3$ & Review & Proctor (1991) \\
0.1 & Review & Price et al. (1997b) \\
$\sim 1$ & Theory & Gallardo and Rodhe (1997) \\
$2-3$ & Electrostatic and lightning model & Cooray (1997) \\
$0.5-1$ & Fit of 2-D model to data for STERAO, 12 July 1996 & DeCaria et al. (2000) \\
$1.4(1-2)$ & Fit of 3-D model to airborne NO measurements & Fehr et al. (2004) \\
$0.75-1$ & and VHF based lightning observations, EULINOX, 21 July 1998 & \\
1 & Fit of 3-D model to data for STERAO, 12 July 1996 & DeCaria et al. (2005) \\
$0.7-1.5$ & Review & Ridley et al. (2005) \\
1 & Fit of 3-D model to data, CRYSTAL-FACE, 16 and 29 July 2002 & Ott et al. (2005) \\
\hline
\end{tabular}

\subsection{3 $\mathrm{LNO}_{\mathrm{x}}$ production per flash}

The $\mathrm{LNO}_{\mathrm{x}}$ production rate per flash in the atmosphere may be derived by various approaches resulting from groundbased (Noxon, 1976), airborne (Chameides et al., 1987), and spaceborne (Beirle et al., 2004b) measurements. The approaches usually distinguish between CG and IC flashes which have different properties:

$$
\begin{aligned}
& G=P_{\mathrm{CG}} f_{\mathrm{CG}}+P_{\mathrm{IC}} f_{\mathrm{IC}}, \\
& f_{f}=f_{\mathrm{CG}}+f_{\mathrm{IC}}
\end{aligned}
$$

The flash extrapolation methods are very sensitive to the value of the productivity ratio $Z=P_{\mathrm{IC}} / P_{\mathrm{CG}}$, i.e. the ratio in 
the number of $\mathrm{NO}_{\mathrm{x}}$ molecules formed per $\mathrm{CG}$ and IC flashes (Bond et al., 2002). For a number ratio $f_{\mathrm{IC}} / f_{\mathrm{CG}}=3$, the global rate $G$ is more than 3 times larger if $Z=1$ instead of $Z=0.1$ is used (Gallardo and Cooray, 1996; Ridley et al., 2005).

Both, the number ratio $f_{\mathrm{IC}} / f_{\mathrm{CG}}$ (see Table 9 , and Fig. 13) and the productivity ratio $Z$ (Table 19) are uncertain. The $f_{\mathrm{IC}} / f_{\mathrm{CG}}$ ratio varies strongly during the life-cycle of a thunderstorm and ratios exceeding 100 have been observed (Dye et al., 2000; DeCaria et al., 2005; Wiens et al., 2005; Ott et al., 2007). New techniques seem to show that lightning can occur in strong thunderstorms (supercells) virtually continuously (Krehbiel et al., 2000; Thomas et al., 2001). Hence, the determination of the flash rate and the IC/CG ratio may be ill-defined and dependent on the observation system used (Dye et al., 2000).

Acoustic data indicate that IC discharges are less energetic than CG ones (Holmes et al., 1971; Rakov and Uman, 2003). One reason could be the decrease of the threshold value for electrical breakdown with altitude. Moreover, the NO production seems to decrease with decreasing ambient pressure for the same energy and peak current (Goldenbaum and Dickerson, 1993; Wang et al., 1998a). Therefore, the productivity ratio $Z=P_{\mathrm{IC}} / P_{\mathrm{CG}}$ has been assumed to be 0.1 in early studies based on estimates of cloud charges, electrostatic potentials and acoustical measurements of the energy of CG and IC discharges (Kowalczyk and Bauer, 1981; Price et al., 1997b), and this value has been used in many followon studies, see Table 12. However, for the same charge neutralisation, an IC flash dissipates more energy than a CG flash (Cooray, 1997). IC flashes may be far longer than CG flashes (Defer et al., 2001). From above clouds, the pulse shape and intensities of IC and CG flashes were observed to exhibit similar waveshapes, radiances and radiant energy densities (Goodman et al., 1988). IC flashes may form more strokes or pulses per flash than CG flashes (Borucki and Chameides, 1984; Goodman et al., 1988). Moreover, the frequent occurrence of narrow NO peaks as observed in field experiments (see, e.g., Fig. 14) is more likely the fresh signature of IC flashes in the vicinity of the measurements in the upper part of the cloud; CG flash plumes signatures would be smoother when reaching the anvil (Höller et al., 2000). Such observations imply high NO productivity per unit length in IC flashes. $Z$ values of the order of 1 are in agreement with some theoretical studies (Bradshaw, 1996; Cooray, 1997; Zhang et al., 2003b) and laboratory results (Gallardo and Cooray, 1996; Cooray and Rahman, 2005). In fact, a few recent analyses of lightning observations and airborne measurements during STERAO (DeCaria et al., 2000), EULINOX (Fehr et al., 2004), and CRYSTAL-FACE (Ott et al., 2005) with cloud model simulations indicate that IC flashes produce about the same amount of NO as CG flashes, see Table 19.

Note that the higher $P_{\mathrm{IC}} / P_{\mathrm{CG}}$ values for STERAO and EULINOX were derived using the ONERA VHF lightning detection system (Defer et al., 2001), which may overestimate the IC/CG number ratio. The derived $P_{\mathrm{IC}} / P_{\mathrm{CG}}$ ra- tio could be even higher when the IC/CG number ratio is smaller. Moreover, the air in flash channels dissociates for temperatures in excess of about $3000 \mathrm{~K}$, far less than the maximum flash temperature reported for $\mathrm{CG}$ flashes. Perhaps IC flashes exceed this threshold temperature high enough for $\mathrm{LNO}_{\mathrm{x}}$ formation more often than expected (Stark et al., 1996; Dye et al., 2000). In fact, it would be desirable to have lightning observation systems measuring the volume of air heated above $3000 \mathrm{~K}$ by flash events.

The production rate per flash may be derived by relating the measured concentration increase, in a certain volume of the thunderstorm, to the number of flashes causing the $\mathrm{NO}_{\mathrm{x}}$ increase in that specific volume of the thunderstorms (Ridley et al., 1996, 2004; Skamarock et al., 2003; Koike et al., 2007). For illustration of the approach and the difficulties involved, we describe the application of the method to an example. Ridley et al. (2004) analyse a moderate-sized and a large thunderstorm during CRYSTAL-FACE on two different days. Because of the limited altitude ranges of the airborne sampling it is not possible to estimate the $\mathrm{NO}_{\mathrm{x}}$ content in the lower part of the storms. Moreover, possible influx from the boundary layer is not subtracted. Hence, the airborne in-situ $\mathrm{NO}_{\mathrm{x}}$ measurements are fully attributed to lightning sources. From the data the mean increase $\Delta \mathrm{NO}_{\mathrm{x}}$ in the anvil relative to background values is estimated (in fact, median values in several altitude intervals are derived). Radar and satellite observations and the airborne measurements are used to estimate the horizontal areas size $A$ of the anvil. The volume of air containing that mixture is the product of this area in various altitude bins and their depths, defining an effective depth of the anvil $\Delta z$. The number $N_{\mathrm{CG}}$ of CG flashes in the thunderstorm is taken as observed by a ground-based lightning detection network. Typical mean IC/CG number ratios of $f_{\mathrm{IC}} / f_{\mathrm{CG}} \approx 2.25$ for Florida, see Fig. 13 (Boccippio et al., 2001), are used to estimate the number of IC flashes, implying large uncertainties for this case. IC and CG flashes are considered equally efficient in $\mathrm{NO}_{\mathrm{x}}$ production $\left(Z=P_{\mathrm{IC}} / P_{\mathrm{CG}}=1\right)$. From this the production of $\mathrm{NO}_{\mathrm{x}}$ per $\mathrm{CG}$ flash is estimated. The global production $G$ is extrapolated based on the ratio between the global flash rate of $f_{f}=44 \mathrm{~s}^{-1}$ worldwide and the number $\left(f_{\mathrm{IC}} / f_{\mathrm{CG}}+1\right) N_{\mathrm{CG}}$ of actual flashes which may have caused the $\mathrm{NO}_{\mathrm{x}}$ production,

$G=\Delta \mathrm{NO}_{\mathrm{x}} A \Delta z\left(M_{N} / M_{\text {air }}\right) \rho_{\text {air }} f_{f} /\left[\left(f_{\mathrm{IC}} / f_{\mathrm{CG}}+1\right) N_{\mathrm{CG}}\right](8)$

with molar mass ratio $M_{N} / M_{\text {air }}=14 / 29$. Table 20 lists the respective values.

Taking into account estimated uncertainties of a factor 1.5 in $\Delta \mathrm{NO}_{\mathrm{x}}$, a factor 1.5 in the volume $A \Delta z$, and a factor 2 in the flash rate (Ridley et al., 2004), the total uncertainty of the global $\mathrm{LNO}_{\mathrm{x}}$ rate may be as large as a factor of 6 . Moreover, the unknown value of the ratio $Z$ of production efficiency $P_{\mathrm{IC}} / P_{\mathrm{CG}}$ in IC and CG flashes causes significant uncertainty. Finally, the extrapolation of the two storm cases, whose individual results differ by a factor of about 5 , to the 
Table 20. Parameters of observed convective events during CRYSTAL-FACE*.

\begin{tabular}{llllllllll}
\hline Date & Cloud top, $\mathrm{km}$ & Flight altitude, $\mathrm{km}$ & $\mathrm{NO}_{\max }, \mathrm{nmol} \mathrm{mol}^{-1}$ & $\begin{array}{l}\Delta \mathrm{NO}_{\mathrm{x}}, \\
\mathrm{nmol} \mathrm{mol}^{-1}\end{array}$ & $A, \mathrm{~km}^{2}$ & $\Delta z, \mathrm{~km}$ & $N_{\mathrm{CG}}$ & $P, 10^{26}$ & $G, \mathrm{Tg} \mathrm{a}^{-1}$ \\
\hline 16 July 2002 & 15.2 & $11.4-14.2$ & 6.5 & $\sim 1$ & 4200 & 4.5 & 392 & $0.33-0.66$ & $1.1-2.2$ \\
29 July 2002 & 13.8 & $12.5-13.8$ & 9.5 & $\sim 4$ & 15000 & $\sim 5$ & $3067 \pm 150$ & $4.5-6.1$ & $5.5-7.5$ \\
\hline
\end{tabular}

*Data from Ridley et al. (2004). $\mathrm{NO}_{\max }=$ observed peak $\mathrm{NO}$ mixing ratio, $\Delta \mathrm{NO}_{\mathrm{x}},=$ effective $\mathrm{NO}_{\mathrm{x}}$ mixing ratio increase, $A=$ horizontal anvil area, $\Delta z=$ effective depth, $N_{C G}=$ number of $\mathrm{CG}$ flashes in the storm, $P=$ number of $\mathrm{NO}_{\mathrm{x}}$ molecules per flash, $G=\mathrm{global} \mathrm{LNO}$ production rate.

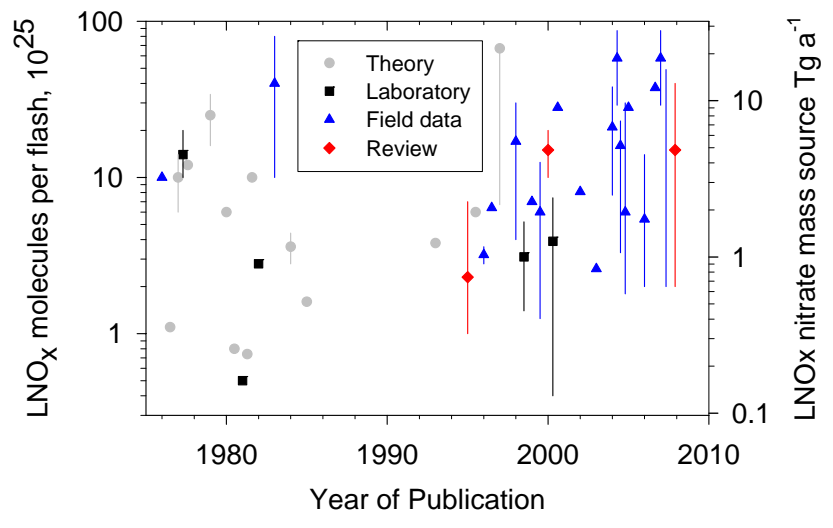

Fig. 25. Flash-specific $\mathrm{LNO}_{\mathrm{x}}$ emissions in $10^{25}$ molecules $\left(\mathrm{NO}_{\mathrm{x}}\right.$ or NO) per flash from various theoretical, laboratory, and field studies and from reviews versus year of publication, according to Table 21. Different symbols denote best-estimates from different approaches and vertical bars the estimated uncertainty ranges. The red symbols refer to the flash-specific emissions derived in the reviews of Lawrence et al. (1995), Bradshaw et al. (2000), and this paper. The right axis measures the total annual global $\mathrm{LNO}_{\mathrm{X}}$-induced nitrate emission rate using the global mean OTD-derived flash rate of $44 \mathrm{~s}^{-1}$ (Christian et al., 2003).

global scale implies further uncertainty. Therefore, the overall uncertainty factor is estimated to be of the order of 10 .

Table 21 summarises previous attempts to derive flashspecific estimates of $\mathrm{LNO}_{\mathrm{x}}$ production published since 1976. Franzblau and Popp (1989) provided an upper extreme value on the number of $\mathrm{NO}_{\mathrm{x}}$ molecules per flash of $300 \times 10^{25}$. For a flash rate of $44 \mathrm{~s}^{-1}$, this value implies an unrealistically large global $\mathrm{LNO}_{\mathrm{x}}$ source of $100 \mathrm{Tg} \mathrm{a}^{-1}$. Such a high value is inconsistent for example with nitrate deposition data (Gallardo and Rodhe, 1997). Without this extreme value, the remaining values scatter between $0.4 \times 10^{25}$ and $67 \times 10^{25}$ molecules per flash (Price et al., 1997b; Cook et al., 2000). Based on the arithmetic mean of the individual results, we find that the best estimate of $\mathrm{LNO}_{\mathrm{x}}$ production per flash is about $15(2-40) \times 10^{25}$ molecules per flash, equivalent to $250 \mathrm{~mol} \mathrm{NO}_{\mathrm{x}}$ or $3.5 \mathrm{~kg}$ of nitrogen per flash, with uncertainty factors 0.13 to 2.7 . The uncertainty range is asymmetric because negative values can be excluded. The range includes most (83\%) of the 39 individual results cited.
The lower bound is consistent with the review of Lawrence et al. (1995). Only a few (four) studies from before 1985 suggested smaller values. Extrapolations of laboratory spark results to natural flashes may have underestimated the $\mathrm{LNO}_{\mathrm{x}}$ productivity. The often used CG value of Price et al. (1997b) defines the upper bound of the set of estimates. They assumed 25 (75)\% of all flashes to be CG (IC) flashes, and IC flashes to be ten times less productive than CG flashes. For equal productivity, the values imply a production rate of $22 \times 10^{25}$ molecules per flash, which is within the given range of uncertainty. The upper bound covers also the recent estimate of Ott et al. (2007), and is consistent with the best estimates of Langford et al. (2004) and Fraser et al. (2007) when accounting for their uncertainty ranges. The range between the lower and upper bounds corresponds to about two to three standard deviations of the individual best-estimate values relative to the mean. Figure 25 (based on Table 21) shows the estimated $\mathrm{NO}_{\mathrm{x}}$ production per flash from theoretical, laboratory, field and review studies versus the year of publication. We see that values below $3 \times 10^{25}$ molecules per flash resulted from mainly theoretical and some laboratory studies in the 1980s. Several of those early results would change when recomputed with present knowledge on flash frequencies and energies. Our present estimate is consistent with the growing number of values derived from field measurements in the more recent years.

The flash-specific $\mathrm{LNO}_{\mathrm{x}}$ values are extrapolated globally using the mean annual global frequency of flashes. The bestestimate value of this frequency, see Table 8 , varied considerably over the years explaining part of the large scatter in previous global $\mathrm{LNO}_{\mathrm{x}}$ source rate estimates. Recent observations show that the lightning flash rate is smaller than expected in early studies. Multiplying the best estimate flashspecific $\mathrm{LNO}_{\mathrm{x}}$ value derived from the collection of existing studies, see Table 21, with the present best estimate of $44 \mathrm{~s}^{-1}$ for the number of flashes derived from OTD data (Christian et al., 2003) results in the $\mathrm{LNO}_{\mathrm{x}}$ production rate of $5 \mathrm{Tg} \mathrm{a}^{-1}$, with a range of uncertainty of $0.6-13 \mathrm{Tg} \mathrm{a}^{-1}$. This range is smaller than the range of values listed in the individual studies. Note that in spite of lower global flash rates the best estimate is larger than in the review of Lawrence et al. (1995), because our flash-specific production rate is higher. 
Table 21. $\mathrm{LNO}_{\mathrm{x}}$ production rate per flash.

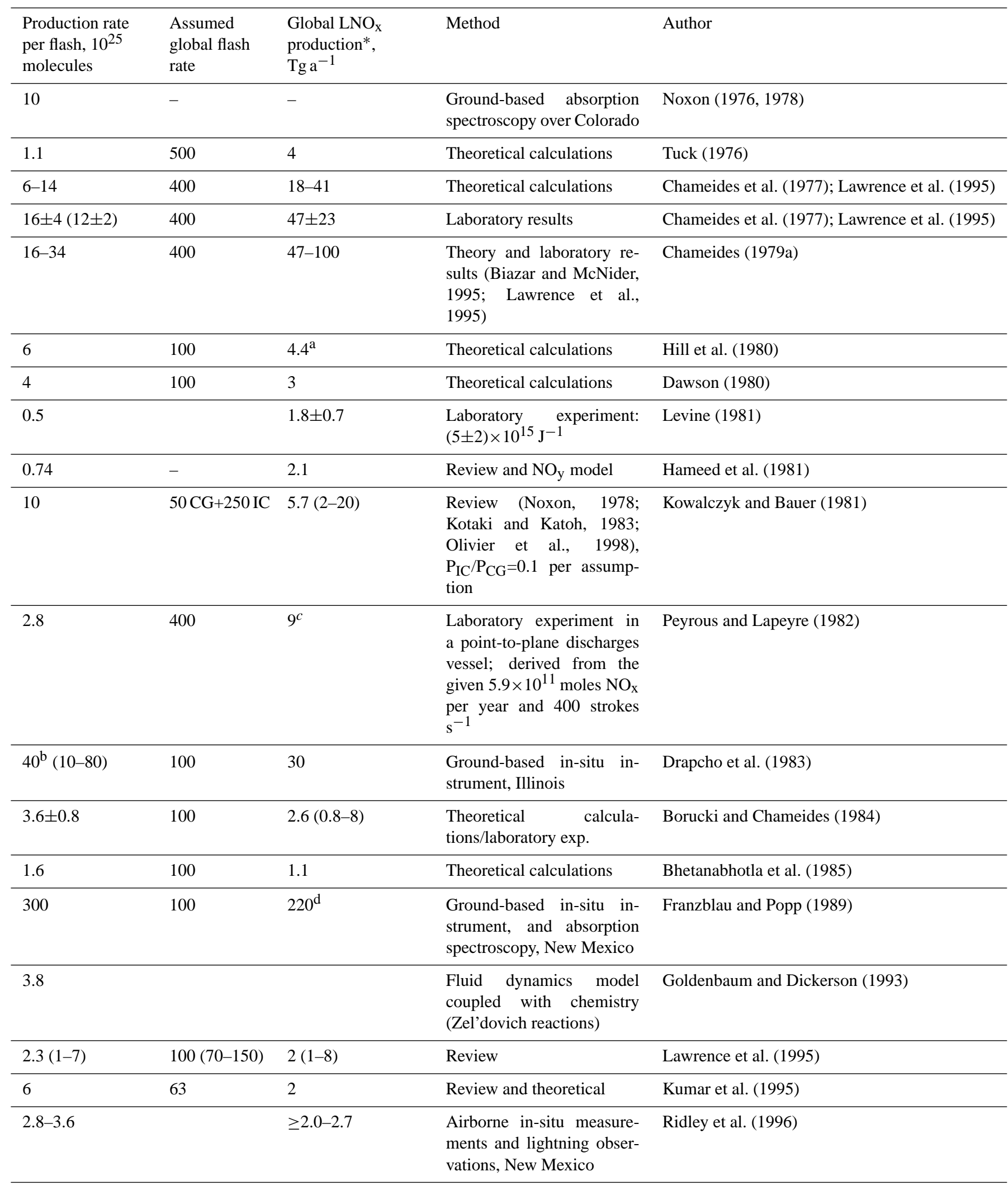


Table 21. Continued.

\begin{tabular}{|c|c|c|c|c|}
\hline $\begin{array}{l}\text { Production rate } \\
\text { per flash, } 10^{25} \\
\text { molecules }\end{array}$ & $\begin{array}{l}\text { Assumed } \\
\text { global flash } \\
\text { rate }\end{array}$ & $\begin{array}{l}\text { Global } \mathrm{LNO}_{\mathrm{x}} \\
\text { production* } \\
\mathrm{Tg} \mathrm{a}^{-1}\end{array}$ & Method & Author \\
\hline 6.4 & 100 & 4.7 & $\begin{array}{l}\text { Ground-based absorption } \\
\text { spectroscopy in core region } \\
\text { of thunderstorm, Pune, } \\
\text { India, } 28 \text { May 1991; flash } \\
\text { detection with electric field } \\
\text { meter and optical sensor }\end{array}$ & Jadhav et al. (1996) \\
\hline $6.7-67$ & $70-100$ & $12.2(11.3-13.1)$ & Theoretical & Price et al. (1997b) \\
\hline $4-30$ & - & $4(0.3-13)$ & $\begin{array}{l}\text { Airborne in-situ mea- } \\
\text { surements, LINOX, } \\
\text { LPATS/BLIDS, average } \\
\text { July 1996, Germany, global } \\
\text { estimate based on the } \\
\text { number of thunderstorms }\end{array}$ & Huntrieser et al. (1998) \\
\hline $3.1(1.4-5.2)$ & $30-100$ & $2.5-8.3(0.7-8.3)$ & $\begin{array}{l}\text { Laboratory in-situ measure- } \\
\text { ments and flash chemistry } \\
\text { model }\end{array}$ & Wang et al. (1998a) \\
\hline 7 & 100 & 5 & $\begin{array}{l}\text { Airborne in-situ measure- } \\
\text { ments, LINOX, Germany, } \\
23 \text { July 1996, and 2-D } \\
\text { model, LPATS/BLIDS }\end{array}$ & Höller et al. (1999) \\
\hline $1.25-12.5$ & - & - & $\begin{array}{l}\text { Airborne in-situ instrument, } \\
\text { STERAO, Colorado, 9-10 } \\
\text { July 1996, VHF interfer- } \\
\text { ometer (ONERA), NLDN, } \\
\text { assuming 5-50 km flash } \\
\text { length }\end{array}$ & Stith et al. (1999) \\
\hline $14-28$ & - & - & $\begin{array}{l}\text { Airborne in-situ instrument, } \\
\text { STERAO, Colorado, 9-10 } \\
\text { July 1996, VHF interferom- } \\
\text { eter (ONERA), NLDN }\end{array}$ & DeCaria et al. (2000) \\
\hline $10-20$ & $\begin{array}{l}25(\mathrm{CG}) 75 \\
(\mathrm{IC})\end{array}$ & $6.5(2-10)$ & Review & Bradshaw et al. (2000) \\
\hline $0.4-7.4$ & $\begin{array}{l}100, \\
30\end{array}$ & $\begin{array}{l}0.6-9.7 \\
0.2-4\end{array}$ & $\begin{array}{l}\text { Laboratory experiments of } \\
\text { low energy sparks }\end{array}$ & Cook et al. (2000) \\
\hline 8.1 & 65 & 4 & $\begin{array}{l}\text { Airborne in-situ instrument, } \\
\text { EULINOX, Germany, } 21 \\
\text { July 1998, VHF interferom- } \\
\text { eter (ONERA) }\end{array}$ & Huntrieser et al. (2002) \\
\hline 2.6 & 44 & 0.8 & $\begin{array}{l}\text { 3-D cloud model, airborne } \\
\text { in-situ measurements, } \\
\text { STERAO, Colorado, } 10 \\
\text { July 1996, VHF interfer- } \\
\text { ometer (ONERA), NLDN }\end{array}$ & Skamarock et al. (2003) \\
\hline
\end{tabular}


Table 21. Continued.

\begin{tabular}{|c|c|c|c|c|}
\hline $\begin{array}{l}\text { Production rate } \\
\text { per flash, } 10^{25} \\
\text { molecules }\end{array}$ & $\begin{array}{l}\text { Assumed } \\
\text { global flash } \\
\text { rate }\end{array}$ & $\begin{array}{l}\text { Global } \mathrm{LNO}_{\mathrm{X}} \\
\text { production*, } \\
\mathrm{Tg} \mathrm{a}^{-1}\end{array}$ & Method & Author \\
\hline $21(7.7-38)$ & - & - & $\begin{array}{l}\text { 3-D cloud model, airborne } \\
\text { in-situ measurements, EU- } \\
\text { LINOX, Germany, } 21 \text { July } \\
\text { 1998, LPATS/BLIDS }\end{array}$ & Fehr et al. (2004) \\
\hline $58 \pm 29$ & - & - & $\begin{array}{l}\text { Ground-based absorption } \\
\text { spectroscopy in core region } \\
\text { of thunderstorm, Colorado, } \\
12 \text { September 2002, NLDN }\end{array}$ & Langford et al. (2004) \\
\hline $3.3-23$ & 44 & $1-8$ & $\begin{array}{l}\text { Airborne in-situ measure- } \\
\text { ments, CRYSTAL-FACE, } \\
16 \text { July and } 29 \text { July 2002, } \\
\text { NLDN }\end{array}$ & Ridley et al. (2004) \\
\hline $6(1.8-30)$ & 63 & $2.8(0.8-14)$ & GOME, Australia, LIS & Beirle et al. (2004b) \\
\hline $21-28$ & - & - & $\begin{array}{l}\text { 3-D cloud model, airborne } \\
\text { in-situ measurements, } \\
\text { STERAO, Colorado, } 10 \\
\text { July 1996, VHF interfer- } \\
\text { ometer (ONERA), NLDN }\end{array}$ & DeCaria et al. (2005) \\
\hline $5.4(2-14)$ & 44 & $1.7(0.6-4.7)$ & $\begin{array}{l}\text { GOME, Gulf of Mexico, } 30 \\
\text { August } 2000, \text { NLDN }\end{array}$ & Beirle et al. (2006) \\
\hline 21.7 & 44 & 7 & $\begin{array}{l}\text { 3-D cloud model, airborne } \\
\text { in-situ measurements, } \\
\text { EULINOX, Germany, } \\
21 \text { July 1998, VHF in- } \\
\text { terferometer (ONERA), } \\
\text { +LPATS/BLIDS, for } 30 \mathrm{~km} \\
\text { flash length }\end{array}$ & Ott et al. (2007) \\
\hline $10-33$ & - & - & $\begin{array}{l}\text { Ground-based absorp- } \\
\text { tion spectroscopy near a } \\
\text { thunderstorm at Vanscoy, } \\
\text { Saskatchewan, } 28 \text { August } \\
\text { 2004; Canadian Lightning } \\
\text { detection network and } \\
\text { Doppler radar }\end{array}$ & Fraser et al. (2007) \\
\hline $2-49$ & 44 & $1-16$ & $\begin{array}{l}\text { Airborne in-situ instru- } \\
\text { ments, BIBLE-C }\end{array}$ & Koike et al. (2007) \\
\hline $15(2-40)$ & $44 \pm 5$ & $5(0.6-13)$ & Mean & This paper \\
\hline
\end{tabular}

* Value stated in the cited paper

a) see comment by Borucki and Chameides (1984).

b) subject to controversy (Franzblau and Popp, 1989; Liaw et al., 1990; Lawrence et al., 1995) because of observations near polluted area.

c) The global $\mathrm{NO}_{\mathrm{x}}$ production rate is stated as $5.9 \times 10^{11}$ moles $\mathrm{a}^{-1}$ and $25 \mathrm{Tg} \mathrm{a}^{-1}$ in Peyrous and Lapeyre (1982).

d) The original paper reported $100 \mathrm{Tg} \mathrm{a}^{-1}$ (Franzblau and Popp, 1989), however the information provided implies $220 \mathrm{Tg} \mathrm{a}^{-1}$ (Liaw et al., 1990). 
As mentioned before, this approach assumes that one set of flash property values exists which is valid for all flashes occurring globally and that the $\mathrm{LNO}_{\mathrm{x}}$ production scales with the number frequency of flashes. However, various indications for variations of flash properties exist. For example peak flash currents over Florida were found to be about twice as large as over New England (Orville, 1990). A later study showed similar results with highest peak currents along the Gulf coast and over Florida (Orville et al., 2002). Differences between OTD-derived global distributions for flash radiances and flash frequencies indicate that the mean radiance per flash (and hence possibly the $\mathrm{LNO}_{\mathrm{x}}$ productivity per flash) is higher over the oceans than over land, and (in the Northern Hemisphere) higher in the wintertime than in summer; moreover, flash radiances are lower when flash-rates are higher (Baker et al., 1999). The median negative current in strong storms is smaller than in nonsevere storms (Carey and Rutledge, 2003). Measurements of global lightning activity using magnetic field variation at very low frequencies $(<300 \mathrm{~Hz})$ reveal the strongest source of lightning activity on Earth over the North American continent and not in the tropics (Füllekrug and Fraser-Smith, 1997). The impact of such variations on the global $\mathrm{LNO}_{\mathrm{x}}$ value is unknown.

Analysis of the frequency distribution of flash peak currents measured with LINET over Southern Brazil (TROCCINOX) (Schmidt et al., 2005) and Germany (Betz et al., 2007) suggests that the stroke peak currents in the tropical thunderstorms may be on average a factor 1.6-2 lower than at midlatitudes, so that tropical strokes may produces less $\mathrm{NO}_{\mathrm{x}}$ than mid-latitudinal ones (Huntrieser et al., 2006). From comparisons of GEOS-CHEM model simulations with $\mathrm{NO}_{\mathrm{x}}$ concentration profiles observed during ICARTT over Southern USA, Martin et al. (2006) and Hudman et al. (2007) suggest that the flash specific $\mathrm{LNO}_{\mathrm{x}}$ production rate may be four times larger at midlatitudes $(500 \mathrm{~mol}$ per flash) than in the tropics (125 mol). From the OTD data, see Fig. 10, we compute that $17.6 \%$ of OTD flashes occur north of $30^{\circ} \mathrm{N}$ and $5.3 \%$ south of $30^{\circ} \mathrm{S}$. If a tropical flash produces $250 \mathrm{~mol}$ of $\mathrm{NO}_{\mathrm{x}}$, but a midlatitude flash four times more $(1000 \mathrm{~mol})$, and if the global flash frequency is $44 \mathrm{~s}^{-1}$ (Christian et al., 2003), then the global $\mathrm{LNO}_{\mathrm{x}}$ source may be as large as $8.2 \mathrm{Tg} \mathrm{a}^{-1}$. If, on the other hand, the tropical flashes are four times less productive $(62.5 \mathrm{~mol}$ per flash), then we obtain a global $\mathrm{LNO}_{\mathrm{x}}$ source of $2.1 \mathrm{Tg} \mathrm{a}^{-1}$. Hence, the uncertainty in flash productivity at various latitudes implies a factor 0.4 1.6 uncertainty relative to the best estimate $\mathrm{LNO}_{\mathrm{x}}$ source of $5 \mathrm{Tg} \mathrm{a}^{-1}$, or a range of $2-8 \mathrm{Tg} \mathrm{a}^{-1}$. This uncertainty is smaller than the uncertainty of the global mean flash-specific productivity (Table 21).

\subsection{Storm extrapolation}

The $\mathrm{LNO}_{\mathrm{x}}$ production estimated for a single thunderstorm may be extrapolated to the globe assuming a known number of thunderstorms active on the globe (Chameides et al.,
1987; Huntrieser et al., 1998, 2002). The method requires to measure the $\mathrm{NO}_{\mathrm{x}}$ concentration increase in the outflow relative to the inflow air and the mass flux of the anvil outflow of a thunderstorm, and to estimate the number $n_{t}$ of thunderclouds active at any time globally. Alternatively, one may estimate the amount of $\mathrm{NO}_{\mathrm{x}}$ induced by lightning within a cloud and extrapolate this value to the global scale according to the number of thunderstorms occurring per day (Ridley et al., 1996, 2004; Skamarock et al., 2003). The advantage of these methods is that no information about the lightning activity and the $P_{\mathrm{CG}} / P_{\mathrm{IC}}$ ratio is required; however, one needs to know the number of active thunderstorms accurately.

Brooks (1925) estimated that about 1800 thunderclouds are active at any time globally from a global survey of annual thunderstorm day reports and the number of lightning flashes observed per thunderstorm. Others cite this number as $n_{t}=2000 \pm 1000$, implying an uncertainty factor of 1.5 to 2 (Chameides et al., 1987; Ridley et al., 1996). For an estimated lifetime of $1 \mathrm{~h}$ this corresponds to a frequency of about $f_{t}=44000$ thunderstorms occurring per day (Viemeister, 1960; Ridley et al., 1996). The order of magnitude of this estimate is confirmed by the number of storms needed to balance the fair-weather current (Rycroft et al., 2000). Williams et al. (2000) test various thunderstorm definitions related to clusters of lightning activity; a global flash frequency of $44 \mathrm{~s}^{-1}$ from 1800 thunderstorms implies 1.5 flashes per minute per thunderstorm, a number which is within the range 1-3 min $^{-1}$ observed with the OTD or LIS sensor.

A five times higher rate of "ordinary thunderstorms" occurrence was derived from estimated precipitation rates and a lifetime of $0.5 \mathrm{~h}$ implying about 200000 such storms per day (Cotton et al., 1995). However, this estimate does not consider the different updraft strengths and lightning activity of such storms. The top $1 \%$ of precipitation features observed by the radar onboard the TRMM satellite, ranked by the flash rate, contributes $90 \%$ of the lightning and $21 \%$ of the rainfall (Cecil et al., 2005). Obviously, it is difficult to define an objective measure of "thunderstorm" (Williams et al., 2000). Hence, the accuracy of $f_{t}$ or $n_{t}$ is hard to improve.

Results obtained for several cases with this method are given in Table 22 from a storm penetration during CITE 1 in fall 1983 near Honolulu, Hawaii (Chameides et al., 1987), from the average of the LINOX and EULINOX observations (Huntrieser et al., 1998, 2002), and from some TROCCINOX 2004 cases (Schumann et al., 2004b). The table contains estimates of the increase in mixing ratio $\Delta \mathrm{NO}_{\mathrm{x}}$, horizontal and vertical sizes of the anvil outflow area $\Delta x \Delta z$, the mean anvil outflow velocity $\Delta v$ relative to the cloud motion at its "steering level" (near $3 \mathrm{~km}$ altitude) (Chameides et al., 1987), and the computed global $\mathrm{LNO}_{\mathrm{x}}$ production rate using

$G=\Delta \mathrm{NO}_{\mathrm{x}} \Delta x \Delta z \Delta v\left(M_{N} / M_{\text {air }}\right) \rho_{\text {air }} f_{t}$,

with $M_{N} / M_{\text {air }}=14 / 29$ as ratio of molar masses, $\rho_{\text {air }}=0.4 \mathrm{~kg} \mathrm{~m}^{-3}$ as air density, and $f_{t}=2000$ active thunderclouds globally. In addition, the maximum NO mixing 
Table 22. $\mathrm{LNO}_{\mathrm{x}}$ related parameters observed in thunderstorm anvils.

\begin{tabular}{|c|c|c|c|c|c|c|c|c|c|c|c|}
\hline Experiment & Case & $\begin{array}{l}\text { Cloud } \\
\text { top, } \\
\mathrm{km}\end{array}$ & $\begin{array}{l}\text { Flight } \\
\text { altitude, } \\
\mathrm{km}\end{array}$ & $\begin{array}{l}\mathrm{NO}_{\max }, \\
\mathrm{nmol}_{\mathrm{mol}^{-1}}\end{array}$ & $\begin{array}{l}\mathrm{NO}_{\mathrm{x}} \text { in- } \\
\text { flow, } \\
\text { nmol } \\
\mathrm{mol}^{-1}\end{array}$ & $\begin{array}{l}\Delta \mathrm{NO}_{\mathrm{X}}, \\
\mathrm{nmol}^{-1} \\
\mathrm{~mol}^{-1}\end{array}$ & $\begin{array}{l}\Delta x, \\
\mathrm{~km}\end{array}$ & $\begin{array}{l}\Delta z, \\
\mathrm{~km}\end{array}$ & $\begin{array}{l}\Delta v, \\
\mathrm{~ms}^{-1}\end{array}$ & $\begin{array}{l}G, \\
\operatorname{Tg~a}^{-1}\end{array}$ & Reference \\
\hline GTE/CITE 1 & & 9 & 9 & 0.9 & - & 1.2 & 40 & 1 & 10 & 5.8 & Chameides et al. (1987) \\
\hline LINOX/EULINOX & medium & & $7-11$ & 0.7 & 0.5 & 1 & 30 & 1 & 8 & $3(2-4)$ & Huntrieser et al. $(1998,2002)$ \\
\hline LINOX/EULINOX & large & & $7-11$ & 1.3 & 0.5 & 1.8 & 45 & 1 & 13 & $\begin{array}{l}12 \\
(10- \\
13)\end{array}$ & dito \\
\hline \multirow[t]{2}{*}{ TROCCINOX } & 14 Feb 2004 & 14.5 & $11-11.3$ & 3.2 & $<0.1$ & 0.4 & 45 & 1 & 7 & $>1.5$ & Schumann et al. (2004b) \\
\hline & 28 Feb 2004 & 11 & $\begin{array}{l}8.8- \\
10.7\end{array}$ & 2.4 & $<0.2$ & 1.2 & 25 & 1.9 & 11 & 7.5 & dito \\
\hline
\end{tabular}

Table 23. $\mathrm{LNO}_{\mathrm{x}}$ production rate per thunderstorm and global extrapolation.

\begin{tabular}{|c|c|c|c|c|c|c|}
\hline Experiment & Thunderstorm type & $\begin{array}{l}\Delta \mathrm{NO}_{\mathrm{x}} \\
\mathrm{nmol} \mathrm{mol}^{-1}\end{array}$ & $\begin{array}{l}F c \\
\operatorname{Tg~s}^{-1}\end{array}$ & $\begin{array}{l}\text { Number or } \\
\text { frequency } \\
\text { of globally } \\
\text { active thun- } \\
\text { derstorms }\end{array}$ & $\begin{array}{l}\text { Global } \mathrm{LNO}_{\mathrm{x}} \\
\text { production, } \\
\mathrm{Tg} \mathrm{a}^{-1}\end{array}$ & Author \\
\hline GTE/CITE 1 & One case near Hawaii & 1.2 & 0.16 & 2000 & 5.8 & Chameides et al. (1987) \\
\hline ELCHEM & $\begin{array}{l}\text { Two cases with } 326-434 \\
\text { flashes/storm }\end{array}$ & & & 44000 day $^{-1}$ & $4.1-4.9$ & Ridley et al. (1996) \\
\hline $\begin{array}{l}\text { LINOX, average } \\
\text { July } 1996\end{array}$ & Small thunderstorms & $0.3-0.8$ & 0.03 & 2000 & $0.3-0.7$ & Huntrieser et al. (1998) \\
\hline dito & Medium thunderstorms & $0.5-1.0$ & 0.13 & 2000 & $2-4$ & dito \\
\hline dito & Large thunderstorms & $1.4-1.9$ & 0.23 & 2000 & $10-13$ & dito \\
\hline EULINOX & $\begin{array}{l}\text { Average over } 29 \text { cases, convec- } \\
\text { tive clouds with lightning }\end{array}$ & $1.3 \pm 0.7$ & 0.11 & 2000 & 3 & Huntrieser et al. (2002) \\
\hline $\begin{array}{l}\text { STERAO, } \\
\text { July } 1996\end{array}$ & Large thunderstorms & - & $\begin{array}{l}3.2- \\
8.8 \mathrm{Mg} / \mathrm{storm}\end{array}$ & 44000 day $^{-1}$ & $52-141$ & Skamarock et al. (2003) \\
\hline
\end{tabular}

ratio measured and the vertical extent of the cloud and the measurement flights are listed which show that parts of the anvils are covered.

Table 23 compiles the production rates as derived from these studies. Also listed is the global thunderstorm rate as assumed in the cited references and the resultant global $\mathrm{LNO}_{\mathrm{x}}$ production. The STERAO result in this table is commented as likely unrealistic by the authors (Skamarock et al., 2003) because the storm observed was exceptional in several respects (Dye et al., 2000).

The thunderstorm based extrapolation results in values of $0.3-13 \mathrm{Tg} \mathrm{a}^{-1}$. In view of estimated uncertainties (Chameides et al., 1987) in the derived concentrations (factor 1.5), outflow fluxes or volumes (factor 1.5), and in the number of thunderstorms (factor 1.5 to 2 ), the best estimates may be $5 \mathrm{Tg} \mathrm{a}^{-1}$ with an uncertainty factor of about 5 . From this, we estimate the range as $1-25 \mathrm{Tg} \mathrm{a}^{-1}$. Hence, this method gives important insight in the properties of various thunderstorms but does not reduce the uncertainty of the global $\mathrm{LNO}_{\mathrm{x}}$ source value.

\subsection{Global model fit}

\subsubsection{Overview}

The global $\mathrm{LNO}_{\mathrm{x}}$ source $G$ may be determined by adjusting the $\mathrm{LNO}_{\mathrm{x}}$ value in a CTM such that the model results, in a suitable norm, best fit measured field properties of the $\mathrm{NO}_{\mathrm{x}}$ and $\mathrm{NO}_{\mathrm{y}}$ concentrations in the upper troposphere in regions with strong $\mathrm{LNO}_{\mathrm{x}}$ contributions (Levy II et al., 1996). $\mathrm{LNO}_{\mathrm{x}}$ is the most dominant $\mathrm{NO}_{\mathrm{x}}$ source in the upper troposphere in the subtropics and tropics and in summer also at higher latitudes (Lamarque et al., 1996; Levy II et al., 1996; Berntsen and Isaksen, 1999; Hauglustaine et al., 2001b; Bond et al., 2002). Hence, comparisons between measured and computed results in these regions should be sensitive to $\mathrm{LNO}_{\mathrm{x}}$ and should allow assessing the validity on assumptions concerning its modelling.

The idea of the global model fit can be illustrated as follows: the concentrations of $\mathrm{NO}_{\mathrm{x}}$ in the upper troposphere and in the boundary layer over continents are of comparable magnitude, while the chemical lifetime of $\mathrm{NO}_{\mathrm{x}}$ (see Table 4) 


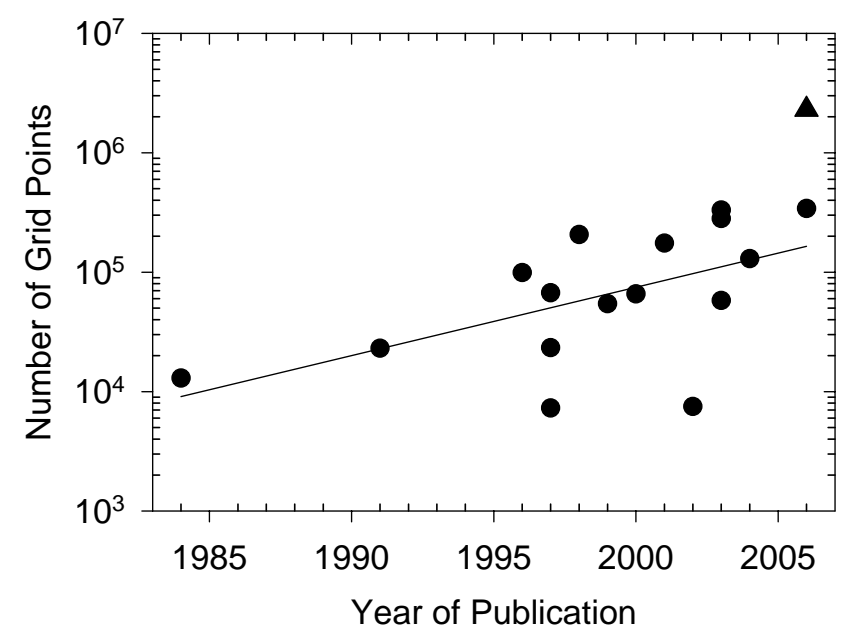

Fig. 26. Growth of numerical resolution in models versus year of publication (based on Table 12). The dots indicate the number of grid points in individual 3-D numerical models, the line represents a linear regression. The triangle denotes the number of grid points in the ECMWF forecast model which is operational since 2006.

in the upper troposphere is about one magnitude larger than in the boundary layer. For the same concentrations but larger lifetimes, the $\mathrm{NO}_{\mathrm{x}}$ source must be correspondingly smaller. Hence, the $\mathrm{NO}_{\mathrm{x}}$ source in the upper troposphere (partly from lightning) must be one order of magnitude smaller than the $\mathrm{NO}_{\mathrm{x}}$ source near the surface. For a total atmospheric $\mathrm{NO}_{\mathrm{x}}$ source of about $50 \mathrm{Tg} \mathrm{a}^{-1}$ (Table 1), released mainly near the surface, an upper tropospheric $\mathrm{LNO}_{\mathrm{x}}$ source of about $5 \mathrm{Tg} \mathrm{a}^{-1}$ is fully consistent with this estimate.

The $\mathrm{LNO}_{\mathrm{x}}$ source may also be determined by adjusting the $\mathrm{LNO}_{\mathrm{x}}$ source in a chemical transport model (CTM) such that the model results best fit the combination of measurements of trace gases which are affected by $\mathrm{LNO}_{\mathrm{x}}$-sources either directly by emissions $\left(\mathrm{NO}_{\mathrm{x}}, \mathrm{NO}_{\mathrm{y}}\right)$ or indirectly by photochemistry $\left(\mathrm{O}_{3}, \mathrm{CO}, \mathrm{HNO}_{3}\right.$, and others) (Martin et al., 2002b, 2007; Müller and Stavrakou, 2005; Schumann et al., 2006). In-situ data for $\mathrm{NO}_{\mathrm{x}}$ and $\mathrm{NO}_{\mathrm{y}}$ from airborne measurements in the mid troposphere over the tropical continents are well suited because of high sensitivity. Satellite-derived $\mathrm{NO}_{2}$ columns (such as from GOME, SCIAMACHY or OMI) may be suitable for selected periods and regions where $\mathrm{LNO}_{\mathrm{x}}$ contributions are larger than model and retrieval biases (van Noije et al., 2006; Martin et al., 2007). These satellites measure during morning or noon hours. This is less of a disadvantage when comparing with global models than with cloud scale models. The air masses carrying the $\mathrm{LNO}_{\mathrm{x}}$ from the day before may become less cloudy over night while the $\mathrm{LNO}_{\mathrm{x}}$ survives longer than a day in the mid and upper troposphere. The thunderstorm outflow plumes may spread to the grid scale of global models during that time.

If the measured concentration at a certain position is $c$, and if the model result for two different $\mathrm{LNO}_{\mathrm{x}}$ source values
$G_{m}>0$ and $G_{b} \geq 0$ are $m$ and $b$ (the "background" solution), and if the true solution scales linearly between these results (i.e., for a sufficiently narrow interval $G_{b} \leq \mathrm{G} \leq G_{m}$ ), then the $\mathrm{LNO}_{\mathrm{x}}$ value is

$G=G_{b}+(c-b) / s, s=(m-b) /\left(G_{m}-G_{b}\right)$.

Hence, high quality estimates of $G$ should be obtainable from accurate measurements $c$ in regions with high sensitivity $s$. For more than one measurement a suitable weighted fit is to be used. Global model results are best compared to largescale measurements in $\mathrm{LNO}_{\mathrm{x}}$ homogeneous air masses while mesoscale models may be compared to small-scale measurements in the vicinity of individual thunderstorms.

Several authors expressed doubts about the feasibility of this approach noting either missing or highly variable data, strong sensitivity of the model results to model parameters (such as emissions from other sources, numerical resolution, transport properties, lightning parameterisation details etc.), and different behaviour of the differences between model results and measurements in various regions of the atmosphere (Singh et al., 1996; Penner et al., 1998; Labrador et al., 2005). Even recently, large discrepancies between various CTMs and observations have been noted (Singh et al., 2006).

Since the first attempts, models, observations, and data analysis methods have been improved in many ways. The number of grid points used in the models increased by more than a factor of 20 over the last 20 years, see Fig. 26, implying an increase of factor 2.7 in spatial resolution in each dimension. Far higher resolution is in use for numerical weather predictions: version T799L91 at ECMWF is operational since February 2006, with $50 \mathrm{~km}$ resolved horizontal wavelength and 91 vertical levels from the surface to about $80 \mathrm{~km}$ (1 Pa) (Untch et al., 2006), i.e. about $2.3 \times 10^{6}$ grid points. Such models will eventually include the necessary chemistry modules for use as CTMs. Resolution is important in many respects. It influences the atmospheric motion field that drives convection, lightning and $\mathrm{LNO}_{\mathrm{x}}$ formation. Also ozone production in global chemical models is dependent on model resolution, because $\mathrm{O}_{3}$ chemistry is inherently nonlinear, the timescales for chemical production are short, and precursors are artificially distributed over the spatial scale of the model grid (Wild and Prather, 2005; Stevenson et al., 2006). With coarser resolution ozone production rate is overpredicted due to artificial dilution of $\mathrm{NO}_{\mathrm{x}}$. Flash plume scale chemistry as considered for aircraft and ship plumes (Petry et al., 1998; Crawford et al., 2000; Kraabøl et al., 2000; Song et al., 2003; von Glasow et al., 2003) may be important for $\mathrm{LNO}_{\mathrm{x}}$ studies but has still to be included in the models.

In addition, models have been improved with better numerical advection schemes, more complete and more accurate air chemistry models, better meteorological input driving the CTMs, more realistic emission databases of tracers other than $\mathrm{LNO}_{\mathrm{x}}$ emissions, and improvements identified from comparisons with observational data and other models 
(Brunner et al., 2003; van Noije et al., 2006). Early models used a linearised $\mathrm{NO}_{\mathrm{x}}$ chemistry (Penner et al., 1991; Ehhalt et al., 1992; Kasibhatla et al., 1993; Kraus et al., 1996; Köhler et al., 1997; van Velthoven et al., 1997), others included full tropospheric chemistry. Some models are specialised in stratospheric chemistry and treat tropospheric chemistry in a simplified manner, but most of the modern models listed in Table 12 use extensive chemical cycles to represent tropospheric chemistry. Techniques have been developed which allow for modular combination of various sub-models (Jöckel et al., 2006). The photochemistry treated had become more and more complex. Modern models treat more than 100 species and reactions, often including reactions with $\mathrm{NMHC}$ (as an $\mathrm{O}_{3}$ precursor), PAN (as a reservoir species for $\mathrm{NO}_{\mathrm{x}}$ ), and acetone (possibly a major $\mathrm{OH}$ source). Acetone was suggested to enhance the effect of $\mathrm{NO}_{\mathrm{x}}$ emitted into the upper troposphere but more recent studies indicate that this effect is smaller than expected earlier (Arnold et al., 2005). PAN acts as a sink for upper tropospheric $\mathrm{NO}_{\mathrm{x}}$ and a source of $\mathrm{NO}_{\mathrm{x}}$ in the remote atmosphere (Crutzen, 1979; Moxim et al., 1996; Müller and Brasseur, 1999; Brühl et al., 2000; Tie et al., 2001).

Many further in-situ and remote sensing data have become available, in particular for tropical continental regions with high $\mathrm{LNO}_{\mathrm{x}}$ sensitivity. The measurement results of many experimental studies have been made available in publicaccessible databases (Emmons et al., 2000; Brunner et al., 2005), and many more such data (in-situ and space observations) are becoming accessible, mostly via internet.

Also the analysis methods have been improved. Whereas early studies compared regional averages of measurements with regional statistics from CTM results obtained with meteorological input from climate models (Levy II et al., 1996) or monthly means of analysis fields (Müller and Brasseur, 1995), more recent studies compare measurements with CTM results driven with actual meteorological analysis fields (Emmons et al., 2000). Modern studies compare model results obtained from "virtual flights" (Lawrence et al., 2003a) with observations from real flights, sampling model results along the flight tracks and times of the measuring aircraft (Schlager et al., 1999; Allen et al., 2000; Meijer et al., 2000; Brunner et al., 2003), see Fig. 22. Moreover, various new statistical analysis methods have been developed to assess the quality of model-observation data comparisons (Brunner et al., 2003) and to determine optimal model parameters with objective error bounds (Müller and Stavrakou, 2005; Schumann et al., 2006). At present not all this progress has been used to determine best-estimate $\mathrm{LNO}_{\mathrm{x}}$ source rates with error bounds.

Many model studies of atmospheric chemistry depending on $\mathrm{LNO}_{\mathrm{x}}$ have been performed, see Table 24. Most models were run with $\mathrm{LNO}_{\mathrm{x}}$ sources and parameterisation taken from the literature with little or no further justification. In some cases, model results were compared to observations but without a systematic strategy to optimize the $\mathrm{LNO}_{\mathrm{x}}$ source.
In only a few model studies, the model results were compared in more detail with observations for various model versions and $\mathrm{LNO}_{\mathrm{x}}$ values, in order to find out the best estimate $\mathrm{LNO}_{\mathrm{x}}$ value and the best model version.

\subsubsection{Deposition-based $\mathrm{LNO}_{\mathrm{x}}$ determination}

The $\mathrm{LNO}_{\mathrm{x}}$ source may be determined by adjusting the $\mathrm{LNO}_{\mathrm{x}}$ source in a chemical transport model (CTM) to fit nitrate deposition measurements in regions with strong $\mathrm{LNO}_{\mathrm{x}}$ contributions. Most of the emitted $\mathrm{NO}_{\mathrm{x}}$ is eventually converted to $\mathrm{HNO}_{3}$ or nitrate aerosol and removed from the atmosphere by rain-out or dry deposition at the ground. The use of nitrate deposition data to constraint the total $\mathrm{NO}_{\mathrm{x}}$ budget has been considered in several studies (Ehhalt and Drummond, 1982; Logan, 1983; Warneck, 1988; Penner et al., 1991; Dentener and Crutzen, 1994; Kraus et al., 1996; Gallardo and Rodhe, 1997; Holland et al., 1997, 1999a, b; Ehhalt, 1999; Levy II et al., 1999; Hauglustaine et al., 2004; Shepon et al., 2007). Observations of nitrate deposition in regions with large anthropogenic $\mathrm{NO}_{\mathrm{x}}$ emissions, such as Europe, the USA, or India (Leeuwen et al., 1996; Hauglustaine et al., 2004; Kulshrestha et al., 2005), are not very sensitive to $\mathrm{LNO}_{\mathrm{x}}$ sources. Data from preindustrial times and from remote stations (Galloway et al., 1982; Albritton et al., 1984; Dentener et al., 2006) may be more suitable for this purpose.

For example, wet nitrate deposition at Barbados $\left(59^{\circ} 30^{\prime} \mathrm{W}, 3^{\circ} 15^{\prime} \mathrm{N}\right)$ was measured in $1989-1994$ to amount to about $50 \mathrm{mg} \mathrm{m}^{-2} \mathrm{a}^{-1}$; calculations with the TM3 model (Lelieveld and Dentener, 2000) show that $\mathrm{LNO}_{\mathrm{x}}$ causes about $30 \%$ of this flux; and the simulated total deposition flux agrees within about $20 \%$ with the observed value (F. Dentener and J. Galloway, personal communication, 2006). The annual mean nitrate concentration at polar stations, which was fairly constant in the preindustrial era, has increased since about the mid of the last century (Wolff, 1995). Snow nitrate content increased from about 50 to $140 \mathrm{ng} \mathrm{g}^{-1}$ at the Dye 3 station, Greenland $\left(44^{\circ} \mathrm{W}, 65^{\circ} \mathrm{N}\right)$ in the period 1940 1980 , and from about 20 to more than $100 \mathrm{ng} \mathrm{g}^{-1}$ at Vostok, Antarctica $\left(107^{\circ} \mathrm{E}, 78^{\circ} \mathrm{S}\right)$ in the period $1970-1990$. The preindustrial values and the increase observed in the last decades may be used to discriminate natural and anthropogenic $\mathrm{NO}_{\mathrm{x}}$ contributions. Legrand and Kirchner (1990) determined that a $\mathrm{LNO}_{\mathrm{x}}$ source of 2.8 to $5.6 \mathrm{Tg} \mathrm{a}^{-1}$ contributes about a third to a half to the $\mathrm{NO}_{3}^{-}$content at the South Pole. A further possibility is to use the ${ }^{15} \mathrm{~N} /{ }^{14} \mathrm{~N}$ ratio in the nitrogen isotopic composition of deposited nitrate to identify $\mathrm{LNO}_{\mathrm{x}}$ sources: About $70 \% \mathrm{LNO}_{\mathrm{x}}$ contribution was identified in rainwater collected on the island of Bermuda $\left(32^{\circ} \mathrm{N}\right.$, $65^{\circ} \mathrm{W}$ ) during the warm season (July-September) (Hastings et al., 2003).

Measurements of dry and wet deposition are not trivial, for example because of bidirectional surface-atmosphere exchange of ammonia $\left(\mathrm{NH}_{3}\right)$ (Trebs et al., 2006) or because of organic nitrogen compounds (Cornell et al., 2003), and 
Table 24. $\mathrm{LNO}_{\mathrm{x}}$ source strength values as used or assessed in global atmospheric models.

\begin{tabular}{|c|c|c|c|}
\hline Author & Model or Method & $\begin{array}{l}\mathrm{LNO}_{\mathrm{x}} \text { nitrogen } \\
\text { source strength, } \\
\mathrm{Tg} \mathrm{a}^{-1}\end{array}$ & Variation, comparison to data \\
\hline Logan et al. (1981) & 2-D model & $<10$ & $\begin{array}{l}\text { Order of magnitude agreement with } \mathrm{NO}_{\mathrm{x}} \\
\text { data (Kley et al., 1981) }\end{array}$ \\
\hline Logan (1983) & $\begin{array}{l}\text { Budget analysis, measured con- } \\
\text { centrations and deposition fluxes }\end{array}$ & $0.8-7.8,<10$ & $\begin{array}{l}\text { Compares with surface and airborne } \mathrm{NO}_{\mathrm{X}} \\
\text { data and nitrate deposition data }\end{array}$ \\
\hline Ko (1986) & 2-D stratospheric model & 2 and 4 & $\begin{array}{l}\text { Compares stratospheric } \mathrm{NO}_{\mathrm{y}} \text { with satel- } \\
\text { lite data }\end{array}$ \\
\hline $\begin{array}{l}\text { Crutzen and Zimmermann } \\
\text { (1991) }\end{array}$ & 3-D MOGUNTIA & 5 & No comparisons with observations \\
\hline Penner et al. (1991) & $\begin{array}{l}\text { 3-D Lagrangian model, without } \\
\text { PAN }\end{array}$ & 3 & $\begin{array}{l}\text { Compares with airborne } \mathrm{NO}, \mathrm{HNO}_{3} \text { and } \\
\text { nitrate deposition data }\end{array}$ \\
\hline Beck et al. (1992) & 2-D model, zonal band $30-60^{\circ} \mathrm{N}$. & 5.2 & $\begin{array}{l}\text { Identifies importance of } \mathrm{LNO}_{\mathrm{x}} \text { for avia- } \\
\text { tion assessments }\end{array}$ \\
\hline Ehhalt et al. (1992) & 2-D model, zonal band $40-50^{\circ} \mathrm{N}$. & 5 & $\begin{array}{l}\text { Identifies importance of convection, } \\
\mathrm{LNO}_{\mathrm{x}} \text { and aviation emissions }\end{array}$ \\
\hline Law and Pyle (1993) & 2-D model & $5(2-20)$ & $\begin{array}{l}\text { Compares with } \mathrm{NO}_{\mathrm{x}} \text { data from STRA- } \\
\text { TOZ at } 2 \text { and } 6 \mathrm{~km} \text { latitude }\end{array}$ \\
\hline Kotamarthi et al. (1994) & $\begin{array}{l}\text { 2-D stratospheric model, revising } \\
\text { (Ko, 1986) }\end{array}$ & 2 and 4 & $\begin{array}{l}\text { Good agreement with STEP } 1987 \mathrm{NO}_{\mathrm{y}} \\
\text { data for both } \mathrm{LNO}_{\mathrm{x}} \text { values }\end{array}$ \\
\hline Müller and Brasseur (1995) & 3-D CTM IMAGES. & 8 & $\begin{array}{l}\text { Rough agreement with NO observations; } \\
\mathrm{HNO}_{3} \text { too low }\end{array}$ \\
\hline Kraus et al. (1996) & $\begin{array}{l}\text { 3-D linear } \mathrm{NO}_{\mathrm{x}}, \mathrm{CTM} \text { with GISS } \\
\text { winds. }\end{array}$ & 5 & $\begin{array}{l}\text { Rough agreement with data of STRATOZ } \\
\text { III and nitrate deposition fluxes over USA }\end{array}$ \\
\hline Atherton et al. (1996) & $\begin{array}{l}\text { 3-D Lagrangian model (Penner et } \\
\text { al., 1991) }\end{array}$ & 10 & $\begin{array}{l}\text { Model and measured } \mathrm{O}_{3}, \mathrm{CO}, \mathrm{NO}_{\mathrm{x}} \text { and } \\
\mathrm{NO}_{\mathrm{y}} \text { data correlate } 40 \text { to } 90 \%\end{array}$ \\
\hline Lamarque et al. (1996) & IMAGES & $\begin{array}{l}5,(2-10), \text { for } 2 \\
\text { emission profiles }\end{array}$ & $\begin{array}{l}\text { Compares results from various model ver- } \\
\text { sions to various data, and identifies some } \\
\text { deficiencies }\end{array}$ \\
\hline Moxim et al. (1996) & 3-D CTM with PAN & $3-10$ & $\begin{array}{l}\text { Simulated and observed PAN data agree } \\
\text { "generally" }\end{array}$ \\
\hline Levy et al. (1996) & 3-D CTM GFDL-GCTM & $4(2-6)$ & $\begin{array}{l}\mathrm{LNO}_{\mathrm{x}} \text { fit to airborne measurements of } \\
\mathrm{NO}_{\mathrm{x}} \text { and } \mathrm{NO}_{\mathrm{y}} \text { gives good agreement }\end{array}$ \\
\hline Jaffe et al. (1997) & GISS GCTM & 5 & $\begin{array}{l}\text { Good agreement with surface } \mathrm{NO}_{\mathrm{x}} \text { but } \\
\text { low model } \mathrm{NO}_{\mathrm{x}} \text { results in remote regions }\end{array}$ \\
\hline Köhler et al. (1997) & $\begin{array}{l}\text { 3-D GCM ECHAM linearised } \\
\mathrm{NO}_{\mathrm{x}} \text { chemistry. }\end{array}$ & 5 & $\begin{array}{l}\text { Measured } \mathrm{NO}_{\mathrm{x}} \text { values often lower than } \\
\text { modelled results }\end{array}$ \\
\hline Gallardo and Rodhe (1997) & 3-D MOGUNTIA & $5(0-24.9)$ & $\begin{array}{l}\text { Larger } \mathrm{LNO}_{\mathrm{x}} \text { emission over the oceans } \\
\text { results in an improved simulation of sur- } \\
\text { face total nitrate in the remote Pacific }\end{array}$ \\
\hline Emmons et al. (1997) & $6 \mathrm{CTMs}$ & $3-12.9$ & $\begin{array}{l}\text { Rough agreement with ground-based and } \\
\text { airborne data }\end{array}$ \\
\hline
\end{tabular}


Table 24. Continued.

\begin{tabular}{|c|c|c|c|}
\hline Author & Model or Method & $\begin{array}{l}\mathrm{LNO}_{\mathrm{X}} \text { nitrogen } \\
\text { source strength, } \\
\mathrm{Tg} \mathrm{a}^{-1}\end{array}$ & Variation, comparison to data \\
\hline Holland et al. (1997) & 5 CTM2 & $3-10$ & $\begin{array}{l}\text { Nitrogen deposition comparisons with } \\
\text { data, no conclusion on } \mathrm{LNO}_{\mathrm{x}}\end{array}$ \\
\hline Pickering et al. (1998) & 3-D IMAGES & 3 & $\begin{array}{l}\text { C-shape emission profile provides higher } \\
\mathrm{NO}_{\mathrm{x}} \text { levels in the upper troposphere than } \\
\text { constant profile }\end{array}$ \\
\hline Dameris et al. (1998) & ECHAM/CHEM & 4 & Good comparisons to $\mathrm{O}_{3}$ column data \\
\hline Hauglustaine et al. (1998) & 3-D MOZART & 7 & $\begin{array}{l}\mathrm{HNO}_{3} \text { overestimated over the Pacific by } \\
\text { a factor }<10 \text {, and over the continental re- } \\
\text { gions by factor }<3\end{array}$ \\
\hline Brasseur et al. (1998b) & 3-D MOZART & 7 & $\mathrm{O}_{3}$ data showing general agreement \\
\hline Wang et al. (1998b) & 3-D Harvard GISS & 3 & No comparisons to observations \\
\hline Singh et al. (1998) & 3-D Harvard GISS & 4 & Rough agreement with PEM-W-B data \\
\hline Smyshlyaev et al. (1999) & 2-D model & $5(2-12)$ & $\begin{array}{l}\text { Finds } \mathrm{LNO}_{\mathrm{x}} \text { induced } \mathrm{O}_{3} \text { changes compa- } \\
\text { rable with TOMS }\end{array}$ \\
\hline Berntsen and Isaksen (1999) & UiO CTM & $12.2(5)$ & No comparisons to observations \\
\hline Levy et al. (1999) & 3-D GFDL & 4 & $\begin{array}{l}\text { Justifies the selected } \mathrm{LNO}_{\mathrm{x}} \text { value by com- } \\
\text { parison with many data }\end{array}$ \\
\hline Müller and Brasseur (1999) & 3-D IMAGES & 3 & No $\mathrm{LNO}_{\mathrm{x}}$ discussion \\
\hline Crutzen et al. (1999) & 3-D MATCH & 1.7 & $\mathrm{NO}_{\mathrm{x}}$ levels were assessed as low \\
\hline Stockwell et al. (1999) & 3-D TOMCAT & 4 & $\begin{array}{l}\mathrm{NO}_{\mathrm{x}}, \mathrm{HNO}_{3}, \mathrm{O}_{3} \text { agree reasonably with } \\
\text { observations }\end{array}$ \\
\hline Holland et al. (1999b) & Review and 3-D MOGUNTIA & $10-15$ & $\begin{array}{l}\text { Discusses wet deposition at northern mid- } \\
\text { latitudes }\end{array}$ \\
\hline Emmons et al. (2000) & MOZART and IMAGES & 3,7 & Identifies too low biomass emissions \\
\hline Moxim and Levy (2000) & GFDL GCTM & 4 & $\begin{array}{l}\text { Model } \mathrm{NO}_{\mathrm{x}} \text { results are within the scatter } \\
\mathrm{NO}_{\mathrm{x}} \text { data from TRACE-A }\end{array}$ \\
\hline $\begin{array}{l}\text { Lelieveld and Dentener } \\
(2000)\end{array}$ & $\begin{array}{l}\text { 3-D CTM based on ECMWF } \\
\text { winds }\end{array}$ & 5 & $\begin{array}{l}\text { Identifies the } \mathrm{LNO}_{\mathrm{x}} \text { source as important } \\
\text { uncertainty }\end{array}$ \\
\hline Allen et al. (2000) & $\begin{array}{l}\text { 3-D CTM with maximum horizon- } \\
\text { tal resolution over eastern North } \\
\text { America and the North Atlantic; } \\
\text { flash rate proportional to convec- } \\
\text { tive mass flux }\end{array}$ & 3.6 & $\begin{array}{l}\text { Compares with SONEX } \mathrm{NO}_{\mathrm{y}} \text { data; the } \\
\text { use of emissions from observed lightning } \\
\text { flashes significantly improves the simula- } \\
\text { tion }\end{array}$ \\
\hline Tie et al. (2001) & 3-D CTM MOZART & 7 & $\begin{array}{l}\mathrm{LNO}_{\mathrm{x}} \text { larger than } 7 \mathrm{Tg} \mathrm{a}^{-1} \text { cannot be ex- } \\
\text { cluded from this study }\end{array}$ \\
\hline Hauglustaine et al. (2001a) & 3-D MOZART & 7 & $\begin{array}{l}\text { Compares qualitatively well with data } \\
\text { from TRACE-A ELCHEM, STERAO }\end{array}$ \\
\hline Grewe et al. (2001) & $\begin{array}{l}\text { 3-D ECHAM/CHEM and GISS } \\
\text { model with CTH and UPD param- } \\
\text { eterisation }\end{array}$ & $5,3.9$ & $\begin{array}{l}\text { NOXAR data mass flux based model per- } \\
\text { forms better than cloud-top-height based }\end{array}$ \\
\hline
\end{tabular}


Table 24. Continued.

\begin{tabular}{|c|c|c|c|}
\hline Author & Model or Method & $\begin{array}{l}\mathrm{LNO}_{\mathrm{x}} \text { nitrogen } \\
\text { source strength, } \\
\mathrm{Tg} \mathrm{a}^{-1}\end{array}$ & Variation, comparison to data \\
\hline $\begin{array}{l}\text { Bey et al. (2001); Li et } \\
\text { al. (2001); }\end{array}$ & 3-D GEOS-CHEM & 3.4 & $\begin{array}{l}\text { Compares with airborne campaigns. NO, } \\
\text { PAN fits well; } \mathrm{HNO}_{3} \text { is overestimated; } \\
\text { finds } 10-15 \% \text { contribution from } \mathrm{LNO}_{\mathrm{x}} \text { to } \\
\text { upper tropospheric } \mathrm{O}_{3} \text { maximum in the } \\
\text { Middle East }\end{array}$ \\
\hline Meijer et al. (2001) & $\begin{array}{l}\text { 3-D TM3 model with cloud-top- } \\
\text { heights and convective precipita- } \\
\text { tion, } 2 \text { vertical distributions }\end{array}$ & 5 & $\begin{array}{l}\text { Comparison with EULINOX and POLI- } \\
\text { NAT/SONEX data supports precipitation } \\
\text { based } \mathrm{LNO}_{\mathrm{x}} \text { model }\end{array}$ \\
\hline Mickley et al. (2001) & 3-D GISS GCMII, & $1-3.6$ & $\begin{array}{l}\mathrm{LNO}_{\mathrm{x}} \text { emissions need to be reduced to } \\
\text { match preindustrial } \mathrm{O}_{3} \text { observations }\end{array}$ \\
\hline $\begin{array}{l}\text { Jourdain and Haugslustaine } \\
\text { (2001) }\end{array}$ & LMDz/INCA & 5 & $\begin{array}{l}\text { For } 5 \mathrm{Tg} \mathrm{a}^{-1} \text { and profile of Pickering et } \\
\text { al. (1998), the model shows good agree- } \\
\text { ment with ELCHEM NO data }\end{array}$ \\
\hline Shindell et al. (2001) & GISS GCM & $\begin{array}{l}3.9 \text { ( } 3.6 \text { in prein- } \\
\text { dustrial time) }\end{array}$ & $\begin{array}{l}\text { Comparison with many data; for } \mathrm{NO}_{\mathrm{x}} \text {, } \\
\text { comparison with NOXAR data shows fac- } \\
\text { tor } 2 \text { differences }\end{array}$ \\
\hline Allen and Pickering (2002) & $\begin{array}{l}\mathrm{LNO}_{\mathrm{x}} \text { parameterisations with dif- } \\
\text { ferent vertical profiles and sources }\end{array}$ & $0.5-18.5$ & $\begin{array}{l}\text { Compares observed and modelled flash } \\
\text { rates }\end{array}$ \\
\hline Grewe et al. (2002) & $\begin{array}{l}\text { 3-D climate-chemistry model } \\
\text { E39/C }\end{array}$ & $\begin{array}{l}5.4 \text { for } 1990 \text { and } \\
5.6 \text { for } 2015\end{array}$ & Aviation $\mathrm{NO}_{\mathrm{x}}$, model parameter study \\
\hline Tie et al. (2002) & 3-D MOZART & $\begin{array}{l}3.5-7, \quad \text { various } \\
\text { vertical profiles }\end{array}$ & $\begin{array}{l}\text { PEM West-A, PEM Tropics, CITE-2, } \\
\text { CITE-3, ECHEM, ABLE and TRACE-A }\end{array}$ \\
\hline Staudt et al. (2002) & 3-D Harvard/Florida CTM & 6 & PEM-Tropics A \\
\hline Martin et al. (2002b) & GEOS-CHEM & 3,6 & $\begin{array}{l}\text { A } \mathrm{LNO}_{\mathrm{x}} \text { source of } 6 \mathrm{Tg} \mathrm{a}^{-1} \text { is shown to } \\
\text { be consistent with TOMS and in-situ ob- } \\
\text { servations of tropospheric ozone over the } \\
\text { tropical Atlantic }\end{array}$ \\
\hline Brunner et al. (2003) & $7 \mathrm{CTMs}$ & 5 & Comparison to aircraft observations \\
\hline Staudt et al. (2003) & 3-D Harvard/Florida CTM & $5(3-9)$ & PEM-Tropics B \\
\hline Horowitz et al. (2003) & 3-D MOZART 2 & 3 & $\begin{array}{l}\text { airborne observations in the upper tropo- } \\
\text { sphere at most locations }\end{array}$ \\
\hline Shindell et al. (2003) & 3-D GISS-GCM & $\begin{array}{l}6.5 \text { ( } 6.2 \text { in prein- } \\
\text { dustrial time) }\end{array}$ & $\begin{array}{l}\text { Model } \mathrm{NO}_{\mathrm{x}} \text { within the scatter of data } \\
\text { from PEM Tropics } \mathrm{B}, \mathrm{PEM} \text { West } \mathrm{B} \text { and } \\
\text { TRACE-A; model } \mathrm{HNO}_{3} \text { generally too } \\
\text { high }\end{array}$ \\
\hline $\begin{array}{l}\text { von Kuhlmann et al. (2003a, } \\
\text { b) }\end{array}$ & 3-D MATCH & 4.9 & $\begin{array}{l}\text { Nitrogen species reproduced within a fac- } \\
\text { tor of } 2 \text { or better, with bias of too small } \\
\mathrm{HNO}_{3} \text { and too large PAN }\end{array}$ \\
\hline Martin et al. (2003) & 3-D GEOS-CHEM & 6.2 & $\begin{array}{l}\text { GOME } \mathrm{NO}_{2} \text { used to fit } \mathrm{NO}_{\mathrm{x}} \text { emissions } \\
\text { for fixed } \mathrm{LNO}_{\mathrm{x}} \text { source }\end{array}$ \\
\hline Labrador et al. (2004) & 3-D MATCH & $2-5(0-20)$ & $\mathrm{LNO}_{\mathrm{x}}$ is varied as free parameter \\
\hline Hauglustaine (2004) & 3-D LMDz-INCA & 5 & $\begin{array}{l}\text { Compares with wet deposition data for } \\
\text { USA and Europe }\end{array}$ \\
\hline
\end{tabular}


Table 24. Continued.

\begin{tabular}{|c|c|c|c|}
\hline Author & Model or Method & $\begin{array}{l}\mathrm{LNO}_{\mathrm{x}} \text { nitrogen } \\
\text { source strength, } \\
\mathrm{Tg} \mathrm{a}^{-1}\end{array}$ & Variation, comparison to data \\
\hline Hudman et al. (2004) & 3-D GEOS-CHEM & 6 & $\begin{array}{l}\text { Model } \mathrm{NO}, \mathrm{HNO}_{3} \text {, and PAN results are } \\
\text { generally within the scatter of data from } \\
\text { the northwest Pacific; no } \mathrm{LNO}_{\mathrm{x}} \text { discus- } \\
\text { sion }\end{array}$ \\
\hline Wong et al. (2004) & 3-D CCM (UiO+SUNYA CCM3) & $3-6$ & $\begin{array}{l}\text { Reproduces } \mathrm{NO}_{\mathrm{x}} \text { and } \mathrm{HNO}_{3} \text { data from } \\
\text { various tropical experiments well, with } \\
\text { some underestimate of } \mathrm{NO}_{\mathrm{x}} \text { in the tropi- } \\
\text { cal upper troposphere }\end{array}$ \\
\hline Stevenson et al. (2004) & STOCHEM, HadAM3 & 7.3 & No comparison with observations \\
\hline Savage et al. (2004) & TOMCAT & 5 & $\begin{array}{l}\text { Model results and GOME } \mathrm{NO}_{2} \text { data show } \\
79 \% \text { correlation; no } \mathrm{LNO}_{\mathrm{x}} \text { discussion }\end{array}$ \\
\hline Labrador et al. (2005) & 3-D MATCH-MPIC & $\begin{array}{l}0<\mathrm{LNO}_{\mathrm{x}}<20 \\
(0-20)\end{array}$ & $\begin{array}{l}\text { Model results and airborne } \mathrm{NO}_{\mathrm{x}} \text { data } \\
\text { show about } 50 \% \text { correlation; best for } \\
5 \mathrm{Tg} \mathrm{a}^{-1} \text { and profile of Pickering et } \\
\text { al. (1998) }\end{array}$ \\
\hline Boersma et al. (2005) & 2 versions of 3-D TM4 & $3.5(1.1-6.4)$ & $\begin{array}{l}\text { Determines } \mathrm{LNO}_{\mathrm{x}} \text { from fit to GOME } \\
\mathrm{NO}_{2} \text { columns }\end{array}$ \\
\hline Lamarque et al. (2005) & 3-D MOZART-2 & $5(2-10)$ & Compares with preindustrial data \\
\hline Müller and Stavrakou (2005) & 3-D IMAGES & $2.8(1.6-3.2)$ & $\begin{array}{l}\mathrm{LNO}_{\mathrm{x}} \text { and } \mathrm{CH}_{4} \text { fit using ground-based } \\
\mathrm{CO} \text { observations, } \mathrm{NO}_{2} \text { columns from } \\
\text { GOME, data from } 14 \text { airborne campaigns, } \\
\text { and prescribed } \mathrm{CH}_{4} \text { lifetime }\end{array}$ \\
\hline Naik et al. (2005) & 3-D MOZART-2 & 3 & Sensitivity study for fixed $\mathrm{LNO}_{\mathrm{x}}$ \\
\hline Dameris et al. (2005) & $\begin{array}{l}\text { 3-D chemistry-climate model } \\
\text { E39/C }\end{array}$ & $4.8-5.4$ & Simulation for period 1960-1999 \\
\hline Gauss et al. (2006) & $\begin{array}{l}7 \text { global atmospheric chemistry } \\
\text { models }\end{array}$ & $4-7(5.4 \pm 0.9)$ & Model intercomparison \\
\hline Sanderson et al. (2006) & STOCHEM/HadAM3 & 7 & Compares to deposition data \\
\hline van Noije et al. (2006) & $\begin{array}{l}17 \text { global atmospheric chemistry } \\
\text { models }\end{array}$ & $3-7(5 \pm 0.9)$ & $\begin{array}{l}\text { Comparison with GOME } \mathrm{NO}_{2} \text { retrievals. } \\
\text { No } \mathrm{LNO}_{\mathrm{x}} \text { discussion }\end{array}$ \\
\hline Stevenson et al. (2006) & $\begin{array}{l}26 \text { global atmospheric chemistry } \\
\text { models }\end{array}$ & $3.7-7$ & $\begin{array}{l}\text { Model intercomparison, and comparison } \\
\text { with } \mathrm{O}_{3} \text { data. Largest uncertainties for } \mathrm{O}_{3} \\
\text { peak over tropical South Atlantic; due to } \\
\text { biomass or } \mathrm{LNO}_{\mathrm{x}}\end{array}$ \\
\hline Martin et al. (2006) & $\begin{array}{l}\text { GEOS-CHEM, Inverse modelling, } \\
\text { SCIAMACHY and airborne data. }\end{array}$ & 7.1 & $\begin{array}{l}\text { Best fit for midlatitude } \mathrm{LNO}_{\mathrm{x}} \text { of } \\
1.6 \mathrm{Tg} \mathrm{a}^{-1} \text { instead of } 0.4 \mathrm{Tg} \mathrm{a}^{-1}\end{array}$ \\
\hline Kurz (2006) & $\begin{array}{l}\text { 3-D ECHAM5/MESSy climate } \\
\text { chemistry model with ECMWF } \\
\text { meteorology }\end{array}$ & 5 & $\begin{array}{l}\text { Updraft mass flux fits TROCCINOX } 2004 \\
\text { data }\end{array}$ \\
\hline Jöckel et al. (2006) & $\begin{array}{l}\text { ECHAM/MESSy1 climate chem- } \\
\text { istry model with ECMWF meteo- } \\
\text { rology }\end{array}$ & 2.2 & $\begin{array}{l}\text { Modelled NO data correlate to } 31 \% \text { with } \\
\text { observations; slight underestimate could } \\
\text { be due to deficit of } \mathrm{NO}_{\mathrm{x}} \text { sources or too } \\
\text { rapid conversion to } \mathrm{HNO}_{3} \text { and PAN }\end{array}$ \\
\hline
\end{tabular}


Table 24. Continued.

\begin{tabular}{|c|c|c|c|}
\hline Author & Model or Method & $\begin{array}{l}\mathrm{LNO}_{\mathrm{x}} \text { nitrogen } \\
\text { source strength, } \\
\mathrm{Tg} \mathrm{a}^{-1}\end{array}$ & Variation, comparison to data \\
\hline Schumann et al. (2006) & $\begin{array}{l}\text { Fit of TM4, MOZART-4, MATCH } \\
\text { and ECHAM/MESSy model re- } \\
\text { sults to TROCCINOX data }\end{array}$ & $4.8 \pm 2.5$ & $\begin{array}{l}\mathrm{LNO}_{\mathrm{X}} \text { source from fit to } \mathrm{NO}, \mathrm{O}_{3} \text {, and } \mathrm{CO} \\
\text { data from TROCCINOX }\end{array}$ \\
\hline Sauvage et al. (2007a) & GEOS-CHEM & $4,6,8$ & $\begin{array}{l}\text { For the model with CTH-computed light- } \\
\text { ning distribution scaled to fit OTD/LIS } \\
\text { data, a } \mathrm{LNO}_{\mathrm{x}} \text { source of } 6 \pm 2 \mathrm{Tg} \mathrm{a}^{-1} \text { is } \\
\text { shown to be consistent with in-situ data } \\
\text { for } \mathrm{O}_{3} \text { and GOME data in the tropics }\end{array}$ \\
\hline Martin et al. (2007) & $\begin{array}{l}\text { GEOS-CHEM with seasonal and } \\
\text { regional mean CTH model results } \\
\text { normalised to OTD flash observa- } \\
\text { tions }\end{array}$ & $6 \pm 2$ & $\begin{array}{l}\mathrm{LNO}_{\mathrm{x}} \text { source from fit to observed } \mathrm{NO}_{2} \text {, } \\
\mathrm{O}_{3} \text {, and } \mathrm{HNO}_{3} \text { satellite data }\end{array}$ \\
\hline
\end{tabular}

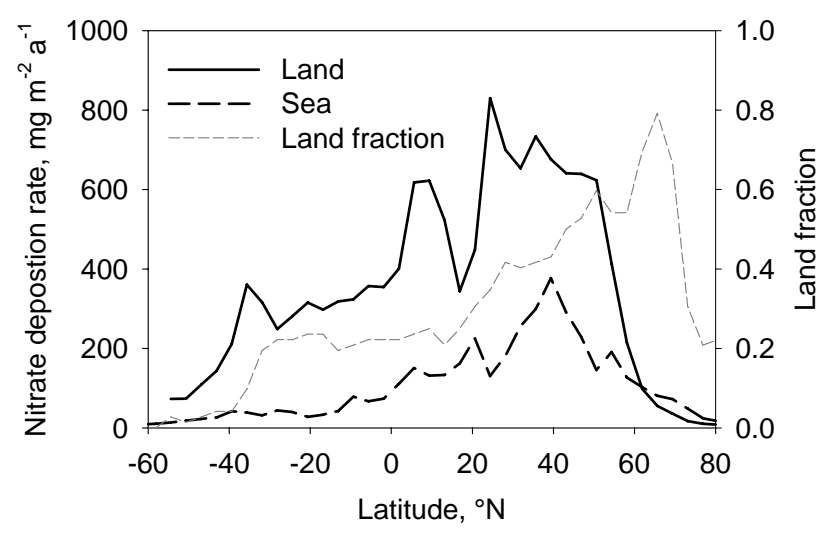

Fig. 27. Annual mean nitrate deposition rate over land (thick full curve) and sea (thick dashed) (in nitrogen mass units) versus latitude as computed from model output data for 1993 (Dentener, 2006), together with land cover fraction (thin dashed).

because problems arise from the quality of the deposition data for various reasons (Kulshrestha et al., 2005). It is often not clear whether the measurements represent the mean deposition value in a model grid cell and whether they include wet deposition only or also dry deposition (Ehhalt and Drummond, 1982). Model results depend on proper treatment of the $\mathrm{NO}_{\mathrm{x}}-\mathrm{NO}_{\mathrm{y}}$ conversions (including PAN etc.) and various models show still large differences in this respect. Moreover, model results depend on the precipitation rates which are mostly taken as input from an external meteorological source (Shepon et al., 2007).

Gallardo and Rodhe (1997), see also Lee et al. (1997), using the MOGUNTIA model for various $\mathrm{LNO}_{\mathrm{x}}$ source values, concluded that a $\mathrm{LNO}_{\mathrm{x}}$ source larger $20 \mathrm{Tg} \mathrm{a}^{-1}$ can hardly be justified in view of deposition fluxes measured at remote tropical stations. Hence, the deposition-based model fit provides an upper bound on the size of the global $\mathrm{LNO}_{\mathrm{x}}$ source. However, this study used a rather coarse model $\left(10^{\circ} \times 10^{\circ}\right.$ horizontally) with monthly averaged wind and precipitation fields.

Lamarque et al. (2005) compared results on continental nitrogen deposition rates from six different tropospheric CTMs. Averaging over all model results, the comparisons of computed and observed deposition rates shows mean values which differ by $14 \%,-10 \%, 60 \%$, and correlation coefficients of 0.3, 0.8, and 0.6 for Europe, North America and Asia, respectively. About $70 \%$ of the emitted nitrogen is deposited over land masses. The authors did not discuss deposition at remote stations and do not assess the accuracy of the assumed $\mathrm{LNO}_{\mathrm{x}}$ source values from this comparison. A recent study evaluated nitrogen (and sulphur) deposition globally and regionally using 23 different atmospheric models (Dentener et al., 2006). Unfortunately, the cited study did not report the $\mathrm{LNO}_{\mathrm{x}}$ contributions to the deposition fluxes. This suggests follow-on studies.

For illustration we present model output for a global $\mathrm{LNO}_{\mathrm{x}}$ source of 5.4 Tg a $\mathrm{T}^{-1}$, see Fig. 27 (Galloway et al., 2004; Dentener, 2006). From the data we compute mean nitrate deposition rates of 45 and $280 \mathrm{mg} \mathrm{m}^{-2} \mathrm{a}^{-1}$ in the southern tropics $\left(0-24^{\circ} \mathrm{S}\right)$ at oceanic and continental sites, respectively. Böttger et al. (1978) derive mean nitrate deposition rates (in terms of nitrogen mass) of $5-50 \mathrm{mg} \mathrm{m}^{-2} \mathrm{a}^{-1}$ for the oceans and $100-200 \mathrm{mg} \mathrm{m}^{-2} \mathrm{a}^{-1}$ for land in the tropics $\left(0-30^{\circ} \mathrm{N}\right)$ which is roughly consistent with these results. From simple estimates of the various emissions, we expect $\mathrm{LNO}_{\mathrm{x}}$ to contribute about $14-23 \%$ of the total $\mathrm{NO}_{\mathrm{x}}$ emissions in the tropics (see Table 2). Hence, a $\mathrm{LNO}_{\mathrm{x}}$ source of about $5 \mathrm{Tg} \mathrm{a}^{-1}$ would be consistent with these deposition values. In order to verify this, one has to compare model results for at least two 
$\mathrm{LNO}_{\mathrm{x}}$ source values with observations in more detail. Such comparison has still to be performed.

\subsubsection{Model studies with comparisons to observational data}

This section reviews a few examples of the many studies comparing model results with data discussing the $\mathrm{LNO}_{\mathrm{x}}$ contribution but without specific conclusion on the best $\mathrm{LNO}_{\mathrm{x}}$ parameterisation. Model simulations concluding on best $\mathrm{LNO}_{\mathrm{x}}$ estimates are summarised in the next section.

Lamarque et al. (1996) used the IMAGES model $\left(5^{\circ} \times 5^{\circ}\right.$ horizontal resolution, monthly averaged meteorological fields) with $\mathrm{LNO}_{\mathrm{x}}$ source rates between 2 and $10 \mathrm{Tg} \mathrm{a}^{-1}$ and two vertical emission profiles (constant by mass or constant by mixing ratio). Most results were obtained for a $\mathrm{LNO}_{\mathrm{x}}$ source of $5 \mathrm{Tg} \mathrm{a}^{-1}$ distributed vertically with constant mixing ratio. The results were compared with a large set of observational data. General agreement was noted, supporting the selected $\mathrm{LNO}_{\mathrm{x}}$ value approximately. Lamarque et al. concluded that a $\mathrm{LNO}_{\mathrm{x}}$ source strength exceeding $20 \mathrm{Tg} \mathrm{a}^{-1}$ would yield model generated mixing ratios of reactive nitrogen oxides in the upper troposphere significantly larger than those typically observed.

Meijer et al. (2001) use the TM3 model $\left(3.75^{\circ} \times 5^{\circ}\right.$ horizontal resolution, driven with ECMWF analysis fields) in two versions. They introduce the CPR parameterisation in addition to the CTH version of Price and Rind (1992). The $\mathrm{LNO}_{\mathrm{x}}$ emissions are distributed vertically as in Price et al. (1997b) (constant vertical profiles for CG and for IC $\mathrm{LNO}_{\mathrm{x}}$ emissions) or as in Pickering et al. (1998) (prescribed $\mathrm{C}$-shaped profile). In both versions the profile is scaled to the cloud-top heights in TM3, and the $\mathrm{LNO}_{\mathrm{x}}$ source amounts to $5 \mathrm{Tg} \mathrm{a}^{-1}$. The model results analysed along the flight paths of the measuring aircraft are compared to measurements performed within the EULINOX and the POLINAT/SONEX campaigns. The CPR parameterisation gives better agreement with observations than the $\mathrm{CTH}$ version; in particular it computes a more realistic $\mathrm{NO}_{\mathrm{x}}$ concentration variability. The prescribed vertical distribution with a $\mathrm{C}$-shape performs better than the older alternative. The model gives good results for the background and thunderstorm outflow cases, but underestimates the observed $\mathrm{NO}_{\mathrm{x}}$ concentrations near active thunderstorms, possibly due to insufficient spatial and temporal resolution in the model.

Grewe et al. (2001) report simulation results of two climate models, the ECHAM/CHEM $\left(3.8^{\circ} \times 3.8^{\circ}\right.$ horizontal resolution) with $5 \mathrm{Tg} \mathrm{a}^{-1}$ and the GISS model $\left(4^{\circ} \times 5^{\circ}\right)$ with $3.9 \mathrm{Tg} \mathrm{a}^{-1}$. Regional-mean model results are compared with corresponding $\mathrm{NO}_{\mathrm{x}}$ data from the NOXAR project (Brunner et al., 2001). The UPD model version performs better than a $\mathrm{CTH}$ version. In particular, though by far not perfect, it better simulates the observed highly skewed probability density function of $\mathrm{NO}_{\mathrm{x}}$ values. The differences in the parameterisations are more important than the differences in the total $\mathrm{LNO}_{\mathrm{x}}$ value.
Jourdain et al. (2001) use a GCM model $\left(2.5^{\circ} \times 3.8^{\circ}\right.$ horizontal resolution) and consider various model versions for a global $\mathrm{LNO}_{\mathrm{x}}$ source rate of $5 \mathrm{Tg} \mathrm{a}^{-1}$ and find that the CTH model version with Pickering's (1998) vertical profile gives good agreement with ELCHEM NO data. Hauglustaine et al. (2004) apply this model and compare to many further observational data (including OTD and nitrate deposition data) but do not assess alternative model versions or $\mathrm{LNO}_{\mathrm{x}}$ source rate values.

Wong et al. (2004) present simulations of present-day and preindustial tropospheric $\mathrm{O}_{3}$, using a global tropospheric climate-chemistry model including a GCM to compute the meteorological fields $\left(2.8^{\circ} \times 2.8^{\circ}\right.$ horizontal resolution $)$. The $\mathrm{LNO}_{\mathrm{x}}$ parameterisation follows Price et al. (1997b), scaled to 3 and $6 \mathrm{Tg} \mathrm{a}^{-1}$, with vertical distributions as in Pickering et al. (1998). For $3 \mathrm{Tg} \mathrm{a}^{-1}$, the model underestimates $\mathrm{NO}_{\mathrm{x}}$ concentrations in the middle and upper troposphere. Increasing the $\mathrm{LNO}_{\mathrm{x}}$ production results in increased upper tropospheric $\mathrm{NO}_{\mathrm{x}}$ concentrations; however, this increase is seasonally dependent and does not account for the discrepancy between the model and the observed results. They find an underestimation of $\mathrm{NO}_{\mathrm{x}}$ levels in particular over convective areas in the tropics, and suggest deficiencies in the $\mathrm{LNO}_{\mathrm{x}}$ parameterisation as possible cause.

Labrador et al. (2005) apply the MATCH model $\left(5.6^{\circ} \times 5.6^{\circ}\right.$ horizontal resolution), a CTM driven with NCEP analysis data, for various $\mathrm{LNO}_{\mathrm{x}}$ parameterisations for $\mathrm{LNO}_{\mathrm{x}}$ between 0 and $20 \mathrm{Tg} \mathrm{a}^{-1}$. They compare the model results with a large set of data. They conclude that a zero $\mathrm{LNO}_{\mathrm{x}}$ source appears too low and $20 \mathrm{Tg} \mathrm{a}^{-1}$ too high. In their opinion, no model version can be singled out as best fitting the observations.

Martin et al. (2006) retrieve tropospheric $\mathrm{NO}_{2}$ columns for May 2004 to April 2005 from SCIAMACHY and derive $\mathrm{NO}_{\mathrm{x}}$ emission estimates via inverse modelling with a global CTM (GEOS-CHEM, with about $2^{\circ} \times 2.5^{\circ}$ horizontal resolution, driven by assimilated meteorological data, with $7.1 \mathrm{Tg} \mathrm{a}^{-1}$ global $\mathrm{LNO}_{\mathrm{x}}$ source rate). The standard simulation with $0.4 \mathrm{Tg} \mathrm{a}^{-1}$ of $\mathrm{NO}_{\mathrm{x}}$ emissions from lightning at northern midlatitudes (north of $30^{\circ}$, where the OTD data find about $22 \%$ of the global lightning activity) was found to underestimate $\mathrm{NO}_{2}$ in the upper troposphere observed by airborne measurements by $0.1 \mathrm{nmol} \mathrm{mol}^{-1}$. The comparison is based on vertical profiles of $\mathrm{NO}_{2}$ over eastern North America averaged over the entire ICARTT campaign. Further comparisons are reported by Hudman et al. (2007). Both studies find that a factor 4 increase of the northern midlatitude lightning source, with fixed emissions in the tropics, minimises bias in the retrieval.

3.3.4 Model studies with best-estimates of the global
$\mathrm{LNO}_{\mathrm{x}}$ rate Levy et al. $(1996,1999)$ report on simulations of tropospheric photochemistry, $\mathrm{NO}_{\mathrm{x}}$ and $\mathrm{NO}_{\mathrm{y}}$ including PAN using 
the GFDL model, based on meteorological results from a GCM, see Table 12. The model includes 11 vertical levels at $2.4^{\circ} \times 2.4^{\circ}$ horizontal resolution. They compare wet deposition and concentration statistics with observations. Levy et al. (1996) estimate the range of the $\mathrm{LNO}_{\mathrm{x}}$ source by systematically comparing computed mean $\mathrm{NO}_{\mathrm{x}}$ and $\mathrm{NO}_{\mathrm{y}}$ values with mean measured values. They use $\mathrm{NO}_{\mathrm{x}}$ and $\mathrm{NO}_{\mathrm{y}}$ measurements from various airborne experiments in tropical regions, primarily between $30^{\circ} \mathrm{S}$ and $30^{\circ} \mathrm{N}$, at altitudes between 500 and $190 \mathrm{hPa}$, mainly over oceans and partly in regions with important biomass contributions. In spite of rather coarse model resolution, they find that $50 \%$ of the comparisons of $\mathrm{NO}_{\mathrm{x}}$ and $\mathrm{NO}_{\mathrm{y}}$ data from observations and the model are within $\pm 25 \%$, without global bias. The measurements, say $c$, are compared with model results, $b$ and $m$ for zero and finite $\mathrm{LNO}_{\mathrm{x}}$ source $G_{m}$. For each subset of data in 13 different regions/altitudes they determine the $\mathrm{LNO}_{\mathrm{x}}$ source $G$ such that the mean model result $m_{\mathrm{opt}}=b+G(m-b) / G_{m}$ approximates the mean observed value $c$ optimally in the experimental region. The regional results imply a global $\mathrm{LNO}_{\mathrm{x}}$ source $G$ which scatters between 1.4 and $21 \mathrm{Tg} \mathrm{a}^{-1}$. From the mean and the standard deviation of the scatter of the $G$ values and a subjective assessment of the validity of the data, the global $\mathrm{LNO}_{\mathrm{x}}$ source is estimated to be within the range 3 to $5 \mathrm{Tg} \mathrm{a}^{-1}$. Implications of systematic model errors are discussed but not quantified. The result for $\mathrm{LNO}_{\mathrm{x}}$ depends critically on the assumed photochemical model (Levy II et al., 1999). Changes in the model causing an increase of upper tropospheric $\mathrm{OH}$ by $50 \%$ on average (factor 2-3 locally) cause quicker oxidation of $\mathrm{NO}_{2}$ into $\mathrm{HNO}_{3}$, and hence lower $\mathrm{NO}_{\mathrm{x}}$ values. This was assessed to imply a larger $\mathrm{LNO}_{\mathrm{x}}$ source of $8-10 \mathrm{Tg} \mathrm{a}^{-1}$. Moreover, the study used only one emission profile with maximum emissions at $7-10 \mathrm{~km}$, which may be too low for tropical continental regions. A profile with emissions at higher altitudes causes larger $\mathrm{NO}_{\mathrm{x}}$ lifetimes and hence best fit to observations for a lower $\mathrm{LNO}_{\mathrm{x}}$ source. The error estimate given by Levy et al. (1996) does not cover these uncertainties.

Tie et al. (2002) use the MOZART model $\left(2.8^{\circ} \times 2.8^{\circ}\right.$ horizontal resolution, driven by meteorological fields from a GCM) and compare the model results with field data obtained in the tropics and over the USA (Emmons et al., 1997). The accuracy is assessed by computing the differences between $\mathrm{NO}_{\mathrm{x}}$ concentrations above $5 \mathrm{~km}$ from various model versions with observed $\mathrm{NO}_{\mathrm{x}}$ values from 14 observation sites. Six model versions were run, including runs for 0 , $1,3.5$ and $7 \mathrm{Tg} \mathrm{a}^{-1}$, with uniform $\mathrm{LNO}_{\mathrm{x}}$ emissions or emissions only in the upper cloud. It is found that the model results deviate strongly from measurements for $\mathrm{LNO}_{\mathrm{x}}$ of 0 and $1 \mathrm{Tg} \mathrm{a}^{-1}$. Also $7 \mathrm{Tg} \mathrm{a}^{-1}$ released in the upper clouds gives large errors. However, $5 \mathrm{Tg} \mathrm{a}^{-1}$ of $\mathrm{LNO}_{\mathrm{x}}$ uniformly distributed in convective clouds or $3.5 \mathrm{Tg} \mathrm{a}^{-1}$ distributed in the upper cloud regions produce both good agreement between calculated and measured $\mathrm{NO}_{\mathrm{x}}$ concentrations in the tropics. The study suggests that $\mathrm{LNO}_{\mathrm{x}}$ is between 3 and $7 \mathrm{Tg} \mathrm{a}^{-1}$ (Tie et al., 2002). Since the uniform $\mathrm{LNO}_{\mathrm{x}}$ emissions case seems less realistic than the emissions only in the upper cloud, this study supports the smaller value $\left(3.5 \mathrm{Tg} \mathrm{a}^{-1}\right)$ more than the larger one.

Martin et al. (2002b) use a version of the GEOS-CHEM model $\left(4^{\circ} \times 5^{\circ}\right.$ horizontal resolution), driven by assimilated meteorological input for 1996/97. They compare the model results with tropospheric ozone column data from TOMS for the same period. Moreover, they compare with in-situ NO and PAN observations (Bey et al., 2001), monthly mean $\mathrm{O}_{3}$ data from ozonesonde stations and from MOZAIC in the tropics, mostly at other periods. The in-situ observations, mainly from measurements over the oceans, provide little constraints on the $\mathrm{LNO}_{\mathrm{x}}$ source in the range $3-6 \mathrm{Tg} \mathrm{a}^{-1}$, though observations from TRACE-A are more consistent with the model results for $6 \mathrm{Tg} \mathrm{a}^{-1}$. However, the $\mathrm{LNO}_{\mathrm{x}}$ source magnitude has a large effect on the tropical tropospheric ozone burden, especially in the middle and upper troposphere of the tropical Atlantic region, where the model results agree with sonde and satellite data for $6 \mathrm{Tg} \mathrm{a}^{-1}$ significantly better than for $3 \mathrm{Tg} \mathrm{a}^{-1}$. A reduction from 6 to $3 \mathrm{Tg} \mathrm{a}^{-1}$ reduces the latitudinal gradient in the middle and upper troposphere, and results in model underestimates of the observed ozone concentrations. The best-estimate result for the $\mathrm{LNO}_{\mathrm{x}}$ source of this study is $6 \mathrm{Tg} \mathrm{a}^{-1}$. The authors leave the uncertainty range undefined.

Staudt et al. (2003) use the global Harvard/Florida CTM model with $4^{\circ} \times 5^{\circ}$ horizontal resolution driven by assimilated meteorological analysis fields and examine the sources and chemistry affecting $\mathrm{NO}_{\mathrm{x}}$ over the tropical Pacific. They compare the model results for $\mathrm{LNO}_{\mathrm{x}}$ sources of 3, 5 and $9 \mathrm{Tg} \mathrm{a}^{-1}$ to observational data from PEM-Tropics $\mathrm{B}$ for $\mathrm{O}_{3}$, $\mathrm{HO}_{\mathrm{x}}, \mathrm{NO}_{\mathrm{x}}, \mathrm{HNO}_{3}, \mathrm{PAN}, \mathrm{CO}$, hydrocarbons and related species. They find that reducing $\mathrm{LNO}_{\mathrm{x}}$ improves the simulations of upper tropospheric $\mathrm{OH}$ and of upper tropospheric $\mathrm{HNO}_{3}$ in the Northern Hemisphere. On the other hand, increasing $\mathrm{LNO}_{\mathrm{x}}$ improves the simulation of $\mathrm{HNO}_{3}$ in the upper troposphere south of $20^{\circ} \mathrm{S}$ while exacerbating the $\mathrm{HNO}_{3}$ overestimate above the North Pacific. The authors provide no best-estimate for $\mathrm{LNO}_{\mathrm{x}}$ but the results suggest a range of 3-9 $\mathrm{Tg} \mathrm{a}^{-1}$.

Boersma et al. (2005) use the TM3 model at $2.5^{\circ} \times 2.5^{\circ}$ horizontal resolution driven by ECMWF analysis fields and fit satellite (GOME) observations, say $c$, of tropospheric $\mathrm{NO}_{2}$ columns to simulated $\mathrm{NO}_{2}$ columns, $b$ and $m$, for a zero and a finite $\mathrm{LNO}_{\mathrm{x}}$ source $G_{m}$ in six oceanic and continental tropical regions of the globe by adjusting a sensitivity or slope parameter $s_{j}$ and a background parameter $b_{j}$ for each region $(j=1, \ldots, 6)$ such that $\Sigma\left(c-b_{j}-s_{j}(m-b)\right)^{2}$ is a minimum regionally and in the annual mean. The background parameter accounts for possible biases, while the sensitivity parameter accounts for the sensitivity of the $\mathrm{NO}_{2}$ columns to $\mathrm{LNO}_{\mathrm{x}}$. A global mean sensitivity $s$ is computed averaging the regional $s_{j}$ values. Finally, the best estimate $\mathrm{LNO}_{\mathrm{x}}$ source is determined from $G=G_{m} / s$. Results for two TM3 model versions 
$\left(\mathrm{LNO}_{\mathrm{x}}\right.$ parameterisation based on either $\mathrm{CTH}$ or CPR) are used to estimate systematic model errors. The two model versions imply $\mathrm{LNO}_{\mathrm{x}}$ estimates of 2.8 and $4.5 \mathrm{Tg} \mathrm{a}^{-1}$. The random and systematic errors are considered and a "conservative" error bound is estimated $\left(1.1-6.4 \mathrm{Tg} \mathrm{a}^{-1}\right)$. The derived error bounds assume random error propagation.

Müller and Stavrakou (2005) use the IMAGES CTM with $5^{\circ} \times 5^{\circ}$ horizontal resolution driven with monthly averaged wind fields. The $\mathrm{LNO}_{\mathrm{x}}$ model source is scaled globally to $3 \mathrm{Tg} \mathrm{a}^{-1}$ and distributed horizontally as in Price et al. (1997b) and vertically as in Pickering et al. (1998). By means of an adjoint modelling technique, they determine improved estimates for the continental emission of $\mathrm{CO}$, surface and lightning $\mathrm{NO}_{\mathrm{x}}$ sources. The estimate uses ground-based $\mathrm{CO}$ observations together with tropospheric $\mathrm{NO}_{2}$ columns from the GOME satellite, and data from 14 airborne campaigns (Emmons et al., 2000). In one version of the analysis the results are constrained to prescribed $\mathrm{CH}_{4}$ lifetime. As a result they find that the $\mathrm{LNO}_{\mathrm{x}}$ source is $2.8 \mathrm{Tg} \mathrm{a}{ }^{-1}$. For various model versions they find a range $1.6-3.2 \mathrm{Tg} \mathrm{a}^{-1}$. They do not explicitly specify the errors in these results due to uncertainties in the model or in the observational data.

Sauvage et al. (2007a) use a version of the GEOS-CHEM model $\left(2^{\circ} \times 2.5^{\circ}\right.$ horizontal resolution, 30 vertical levels up to $0.1 \mathrm{hPa}$ ), driven by assimilated meteorological input. They compare monthly averaged model results with observations for tropospheric $\mathrm{O}_{3}, \mathrm{NO}_{2}$ and $\mathrm{HCHO}$ columns from GOME, lightning flashes from OTD and LIS, profiles of $\mathrm{O}_{3}, \mathrm{CO}$, and relative humidity from MOZAIC, and profiles of $\mathrm{O}_{3}$ from an ozonesonde network (SHADOZ). The model computes $\mathrm{LNO}_{\mathrm{x}}$ using the $\mathrm{CTH}$ method with Pickering-profiles and an IC/CG $\mathrm{NO}_{\mathrm{x}}$ production ratio of 0.1 . The global $\mathrm{LNO}_{\mathrm{x}}$ sources rate is varied $\left(4,6\right.$, and $\left.8 \mathrm{Tg} \mathrm{a}^{-1}\right)$. They find that tropical tropospheric ozone is very sensitive to the $\mathrm{LNO}_{\mathrm{x}}$ model. Scaling the spatial distribution of lightning in the model to the OTD/LIS-observed flash counts improves the simulation of $\mathrm{O}_{3}$ in the upper troposphere by $10-45 \%$. A $\mathrm{LNO}_{\mathrm{x}}$ rate of $6 \pm 2 \mathrm{Tg} \mathrm{a}^{-1}$ best represents in-situ $\mathrm{O}_{3}$ observations from aircraft and ozonesondes. Outside of that range, the simulated $\mathrm{O}_{3}$ was found to become increasingly inconsistent with in situ measurements. A uniform increase of the IC/CG $\mathrm{NO}_{\mathrm{x}}$ production ratio from 0.1 to 0.75 (for constant total global $\mathrm{LNO}_{\mathrm{x}}$ rate) introduces an $\mathrm{O}_{3}$ overestimate compared to in-situ measurements (mainly in the tropics). Moreover, the authors found a strong sensitivity of the results to meteorological datasets provided by two versions of the analysis scheme.

A further recent study with a slightly different version of the same model finds the same result, $6 \pm 2 \mathrm{Tg} \mathrm{a}^{-1}$ (Martin et al., 2007). This $\mathrm{LNO}_{\mathrm{x}}$ range is obtained by comparing the model results with observations of trace gases from four satellite platforms: tropospheric $\mathrm{NO}_{2}$ columns from SCIAMACHY, tropospheric $\mathrm{O}_{3}$ columns from OMI and from the Microwave Limb Sounder (MLS), and upper tropospheric $\mathrm{HNO}_{3}$ from the Atmospheric Chemistry Experiment Fourier
Transform Spectrometer (ACE-FTS).

A recent comparison of the GEOS-CHEM model results of upper tropospheric $\mathrm{NO}_{2}$ data relative to OSIRIS observations suggests a higher $\mathrm{LNO}_{\mathrm{x}}$ source of about $9 \mathrm{Tg} \mathrm{a}^{-1}$ (Sioris et al., 2007). However, the authors consider this high value to be related to the assumed vertical distribution of $\mathrm{LNO}_{\mathrm{x}}$ in the model and the coarse vertical resolution of the observations.

In an ongoing study we use several chemical transport models (ECHAM5/MESSy1, TM4, MOZART-4, MATCHMPIC) with $1.9^{\circ} \times 1.9^{\circ}$ to $3^{\circ} \times 2^{\circ}$ horizontal resolution and meteorological fields from weather analysis or a GCM nudged to ECMWF analysis and various $\mathrm{LNO}_{\mathrm{x}}$ parameterisations (CTH, UPD or CPR) to compute the concentrations of $\mathrm{NO}_{\mathrm{x}}, \mathrm{NO}_{\mathrm{y}}, \mathrm{CO}$ and $\mathrm{O}_{3}$ for at least 2 values of the nominal $\mathrm{LNO}_{\mathrm{x}}$ source, and compare the model results interpolated along flight paths with recent observations in the continental tropics and subtropics (TROCCINOX). By a least square fit, we determine the $\mathrm{LNO}_{\mathrm{x}}$ value for which the model results provide the best fit to the observations. From the magnitude of the deviations between model and observational data we compute systematic error estimates using the model-derived $\mathrm{LNO}_{\mathrm{x}}$ sensitivity. Only the results from the model exhibiting the smallest systematic errors in this application are taken for the final best estimate. The results from the model TM4 with $3^{\circ} \times 2^{\circ}$ horizontal resolution, meteorological data from the ECMWF, and CPR based parameterisation show the best agreement with the observed data. Based on the data of TROCCINOX and this model, a best estimate of $4.8 \mathrm{Tg} \mathrm{a}^{-1}$ is computed with an uncertainty range $2.3-7.3 \mathrm{Tg} \mathrm{a}^{-1}$ (Schumann et al., 2006).

\subsubsection{Results, uncertainties, and future improvements}

Figure 28 shows the $\mathrm{LNO}_{\mathrm{x}}$ values as used in the model studies listed in Table 24 versus the year of publication. The figure shows that even the more recent studies allow for a wide range of $\mathrm{LNO}_{\mathrm{x}}$ values between 1 and $20 \mathrm{Tg} \mathrm{a}^{-1}$, though most studies assumed values between 3 and $7 \mathrm{Tg} \mathrm{a}^{-1}$. Not all these studies compare model results for various $\mathrm{LNO}_{\mathrm{x}}$ emissons with observations. Nevertheless, the results are generally consistent with the findings from the more specific studies. Nine specific studies as explained above determine the best fitting $\mathrm{LNO}_{\mathrm{x}}$ value by comparing model results with observations.

All together the model fit studies performed so far provide a $\mathrm{LNO}_{\mathrm{x}}$ source estimate in the range $2-8 \mathrm{Tg} \mathrm{a}^{-1}$ or $(5 \pm 3) \mathrm{Tg} \mathrm{a}^{-1}$. The accuracy is not necessarily equal to the difference between the upper and lower $\mathrm{LNO}_{\mathrm{x}}$ values used to embrace the best estimate in the individual model fits. The best-estimate may change and the error bounds may increase when further data are included and when other model parts get improved. Even for the given results, the uncertainty is still large, $3 \mathrm{Tg} \mathrm{a}^{-1}$ or about $66 \%$, but far smaller than in most previous reviews, see Table 1. Lawrence et al. (1995) derived a best-estimate of $2 \mathrm{Tg} \mathrm{a}^{-1}$ and a range of $1-8 \mathrm{Tg} \mathrm{a}^{-1}$. Our 


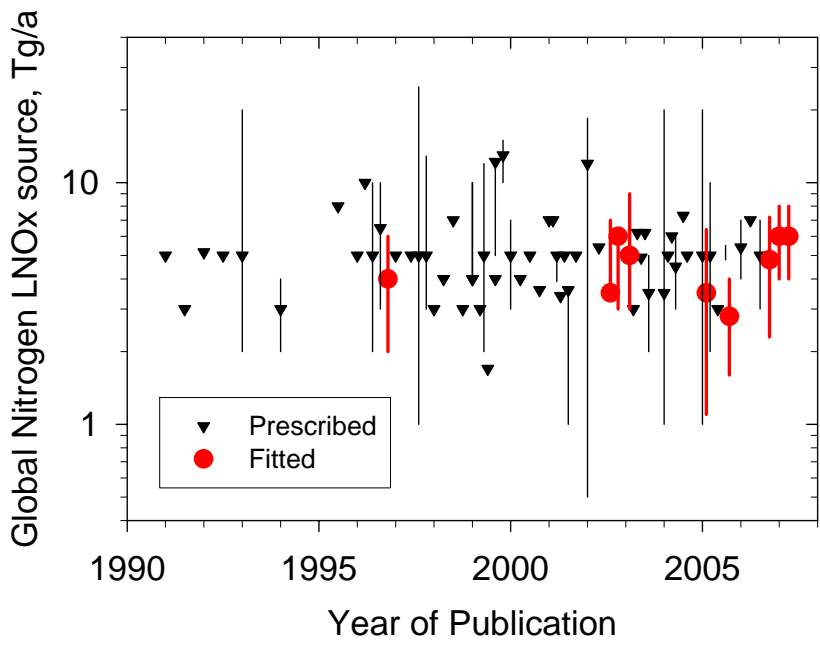

Fig. 28. Global annual nitrogen mass $\mathrm{LNO}_{\mathrm{x}}$ source as prescribed or fitted to data in global atmospheric model studies versus year of publication, as listed in Table 24. Triangles with vertical bars denote estimated values and expected uncertainty ranges. Thick red dots with error bars denote model fit $\mathrm{LNO}_{\mathrm{x}}$ results and the derived uncertainty ranges (Levy II et al., 1996; Martin et al., 2002b, 2007; Tie et al., 2002; Staudt et al., 2003; Boersma et al., 2005; Müller and Stavrakou, 2005; Schumann et al., 2006; Sauvage et al., 2007a).

range is essentially the same, but encloses the best estimate more symmetrically. Our best estimate is larger in spite of the smaller global flash rate used (44 instead of $100 \mathrm{~s}^{-1}$ ) implying larger flash-specific $\mathrm{NO}_{\mathrm{x}}$ emissions $\left(15 \times 10^{25}\right.$ instead of $2.3 \times 10^{25} \mathrm{NO}$ molecules per flash). The present uncertainty is small enough for some of the applications discussed in Sect. 2.10, and appears to be smaller than the uncertainty ranges assessed in this review for the flash or thunderstorm extrapolation methods.

What accuracy can be expected from the model fit approach? Random errors are reducible by including many data; systematic errors are reducible by selecting high quality model and observation data with relatively high $\mathrm{LNO}_{\mathrm{x}}$ sensitivity. The systematic errors arise because of incorrect models and observation methods and control the accuracy achievable when many data are available.

For a conservative estimate we assume that the systematic errors are additive in the absolute norm (where all errors $\Delta$ enter with their absolute amount). Using Eq. (10), the systematic error $\Delta G$ of $G$ follows from

$$
\begin{aligned}
\Delta G / G & =(\Delta c+\Delta b) /(c-b)+\Delta s / s \\
& =(\Delta c / c) c /(c-b)+(\Delta b / b) b /(c-b)+\Delta s / s \\
& =(\Delta c / c) / \alpha+(\Delta b / b)(1-\alpha) / \alpha+\Delta s / s,
\end{aligned}
$$

with $\alpha=(c-b) / c$ measuring the relative $\mathrm{LNO}_{\mathrm{x}}$ contribution to $c$. This shows that systematic errors in the estimated $\mathrm{LNO}_{\mathrm{x}}$ source $G$ originate from systematic errors in three terms: the data $(\Delta c / c)$, the background model results $(\Delta b / b)$, and the sensitivity $(\Delta s / s)$ of the model results to changes in the $\mathrm{LNO}_{\mathrm{x}}$ source value. The first two terms enter with higher weight $\alpha^{-1}$. Hence, accurate results can be obtained only from data with large $\mathrm{LNO}_{\mathrm{x}}$ contribution $\alpha$. To make things simpler, let us assume that the relative errors in the three terms are of comparable magnitude, i.e. $\Delta c / c \approx \Delta b / b \approx \Delta s / s \approx \varepsilon$. Then the total systematic error is

$\Delta G / G=2 \varepsilon / \alpha$.

Hence, the final error $\Delta G / G$ is larger the larger $\varepsilon$ is and the smaller $\alpha$ is. In order to achieve an accuracy $\Delta G / G$ of better than about $100 \%$, the individual errors $\varepsilon$ must stay below $\alpha / 2$. For, e.g., $\alpha<0.5$, the individual errors must stay below $25 \%$. This seems just achievable and hence, is consistent with the derived accuracy of about $100 \%$ from the ensemble of model fits. Obviously, it is difficult to achieve $G$ values with uncertainties far smaller than $100 \%$.

Coming back to the deposition-based $\mathrm{LNO}_{\mathrm{x}}$ determination, we note again that a $\mathrm{LNO}_{\mathrm{x}}$ source of about $5 \mathrm{Tg} \mathrm{a}^{-1}$ causing deposition values as described in Sect. 3.3.2 does not appear unrealistic. However, for an uncertainty of about $30 \%$ in the measured and computed deposition rates and a $\mathrm{LNO}_{\mathrm{x}}$ contribution of $20 \%$ (Table 2), the uncertainty in any $\mathrm{LNO}_{\mathrm{x}}$ estimate derived from these data is of the order of a factor 3. Improvements may be obtained with data from remote stations (Galloway et al., 1982; Dentener et al., 2006), in particular in the southern tropics during the wet season when biomass burning contributions are low (Savoie et al., 1989), or in Antarctica (Weller et al., 2002). However models predict very small nitrate deposition fluxes for Greenland and Antarctica (Dentener et al., 2006), see also Fig. 27.

In the future, more accurate $\mathrm{LNO}_{\mathrm{x}}$ estimates may be derived using all the data sensitive to $\mathrm{LNO}_{\mathrm{x}}$ sources from the many experimental studies performed so far, including insitu, remote sensing, and deposition data. Moreover, global atmospheric models should be further improved. Improvements are needed in particular in the parameterisations of the horizontal distribution of lightning and the vertical profile of the $\mathrm{LNO}_{\mathrm{x}}$ emissions, and in all the other properties determining the quality of the global atmospheric models, such as grid resolution, meteorological input fields, emission estimates from other than $\mathrm{LNO}_{\mathrm{x}}$ emissions, chemical reactions and deposition parameters. Critical tests for model improvements include the ability of the models to compute cloud and lightning distributions as observed from satellites (Christian et al., 2003; Takayabu, 2006; Zipser et al., 2006), the ability to represent the other highly uncertain $\mathrm{NO}_{\mathrm{x}}$ sources such as those from soils (Jaeglé et al., 2004) or biomass burning (Granier et al., 2004), to represent $\mathrm{NO}_{\mathrm{x}}$ concentrations and related photochemistry both at tropical and midlatitudes in the altitude range from the surface to the tropopause, and to represent the skewed probability distribution on $\mathrm{NO}_{\mathrm{x}}$ (Brunner et al., 2001; Hudman et al., 2007) which reflect both the uneven distribution of the sources and the short $\mathrm{NO}_{\mathrm{x}}$ lifetimes. 


\section{Conclusions}

This review covers research aimed at quantifying the $\mathrm{LNO}_{\mathrm{x}}$ source rate $G$ and its distribution in some detail from the first estimates published. The lightning physics and atmospheric chemistry are covered only briefly. More emphasis is given to observations available and to global models which are seen as crucial for further progress. The paper identifies the necessary and achievable accuracy of $\mathrm{LNO}_{\mathrm{x}}$ estimates.

The precise knowledge of the $\mathrm{LNO}_{\mathrm{x}}$ source is important for understanding and predicting the nitrogen oxides and ozone distributions and their trends, the oxidising capacity of the atmosphere, and the lifetime of trace gases destroyed by reactions with $\mathrm{OH}$. In addition, the $\mathrm{LNO}_{\mathrm{x}}$ source must be known accurately for assessment of other important sources besides surface sources, in particular from aviation and the stratosphere. Finally, the $\mathrm{LNO}_{\mathrm{x}}$ source must be known for understanding the possible feedback between climate changes and lightning. Some of the early estimates tended to overestimate the source rate for various reasons, while recent findings suggest smaller $\mathrm{LNO}_{\mathrm{x}}$ values.

Various methods have been used so far to provide $\mathrm{LNO}_{\mathrm{x}}$ estimates. Method 1 (flash extrapolation) has been improved in recent years mainly by using airborne observations of $\mathrm{NO}_{\mathrm{x}}$ increases in thunderstorm outflows together with simultaneous observations of lightning activity. Applications of the flash extrapolation to satellite-derived $\mathrm{NO}_{2}$ column data were successful in case studies for regions with high $\mathrm{LNO}_{\mathrm{x}}$ contributions. Attention has been given to the laboratory finding that the $\mathrm{NO}_{\mathrm{x}}$ production rate is a function of flash peak current. The peak current may be observable from groundbased VLF/LF lightning detection systems. The results from airborne studies have been interpreted with cloud-resolving models and these studies have identified the flash-specific production rates and the ratio in $\mathrm{NO}_{\mathrm{x}}$ productivity for $\mathrm{IC}$ and CG flashes. The results for midlatitude thunderstorms suggest that IC and CG flashes produce about the same amount of $\mathrm{NO}_{\mathrm{x}}$ per flash. The results are extrapolated globally using the ratio between the global flash rate and the flash rate during the thunderstorm investigated. Satellite lightning detection systems observe each point on Earth only for about $15 \mathrm{~h}$ each year (Christian et al., 2003). Nevertheless, the global flash rate appears to be well assessed with OTD and LIS data. However, the various instruments measure signals from different parts of the lightning discharge, and no instrument can determine precisely the number, length, peak current and energy of the flashes. The lightning observations may miss some low-current flash events contributing to $\mathrm{NO}_{\mathrm{x}}$ production. Also it would be important to better understand the processes in flashes contributing to $\mathrm{LNO}_{\mathrm{x}}$ production. This knowledge is needed as the various types of lightning detection instruments are sensitive to different processes. Note that flash channels exceeding $3000 \mathrm{~K}$ may contribute to $\mathrm{NO}_{\mathrm{x}}$ production and such rather cold channels may perhaps be underrepresented in the observations performed so far. Recently, Rahman et al. (2007) suggested that relatively slow discharge processes, with quasi-steady continuing currents of the order $100 \mathrm{kA}$, contribute significantly to the global $\mathrm{LNO}_{\mathrm{x}}$ production. Long continuing currents may follow in particular low peak current strokes (Saba et al., 2006b). Such quasi-steady currents are hardly detectable by most operational lightning detection systems and not included in $\mathrm{LNO}_{\mathrm{x}}$ models so far.

The best estimate for method 1, derived from the reviewed flash studies, including laboratory, theoretical and airborne studies, is $15(2-40) \times 10^{25}$ molecules per flash, equivalent to $250 \mathrm{~mol} \mathrm{NO}_{\mathrm{x}}$ or $3.5 \mathrm{~kg}$ of nitrogen mass per flash with uncertainty factors 0.13 to 2.7. Multiplying this flashspecific value with the satellite- (OTD-)derived global flash frequency of $44 \mathrm{~s}^{-1}$, which is a smaller value than estimated in earlier studies, and assuming equal IC and $\mathrm{CG} \mathrm{NO}_{\mathrm{x}}$ productivity, gives a global $\mathrm{LNO}_{\mathrm{x}}$ value of $0.6-13 \mathrm{Tg} \mathrm{a}^{-1}$. Further reduction of this uncertainty range with this method is difficult for several reasons, in particular because the method assumes that the properties of flashes are uniform at global scale. However, the flash productivity at midlatitudes may be higher than in the tropics (Huntrieser et al., 2006).

Method 2 (storm extrapolation) has been applied to a few thunderstorm cases at midlatitudes and recently also in the tropics and subtropics. The global $\mathrm{LNO}_{\mathrm{x}}$ estimates obtained include a range of about $1-25 \mathrm{Tg} \mathrm{a}^{-1}$. The method does not require knowing the flash properties. The results are helpful in understanding differences between the $\mathrm{LNO}_{\mathrm{x}}$ productions of different types of thunderstorms. However, the method suffers from the ill-defined number of thunderstorms active at any time globally.

Method 3 (global model fit), using concentration data of $\mathrm{NO}_{\mathrm{x}}, \mathrm{NO}_{\mathrm{y}}$, and $\mathrm{NO}_{\mathrm{x}}$ dependent species and deposition data in regions with high $\mathrm{LNO}_{\mathrm{x}}$ sensitivity, has been applied with various models. The method determines the best estimate $\mathrm{LNO}_{\mathrm{x}}$ value by adjusting model parameters such that the model fits observations as well as possible. The accuracy of the result depends strongly on the accuracy of the measured data, the accuracy of the model results for background concentrations (for best a priori $\mathrm{LNO}_{\mathrm{x}}$ estimates), and the sensitivity of the $\mathrm{NO}_{\mathrm{x}}$ concentrations to changes in the $\mathrm{LNO}_{\mathrm{x}}$ source. A simple error estimate shows that the individual errors must be below about $25 \%$ and the $\mathrm{LNO}_{\mathrm{x}}$ contribution to the fitted observations must be larger than 50\%; otherwise the resultant $\mathrm{LNO}_{\mathrm{x}}$ uncertainty is likely to exceed $100 \%$. A large set of chemical transport models has been developed which have been shown to provide good results through comparisons with a growing number of observations and with other models. Most models agree with observations up to a factor 1.2 to 2 , but the agreement is not uniform over the globe. So far, the model results were tested on only a subset of the available data. Recent in-situ measurements obtained in the tropics and subtropics during the projects BIBLE, CRYSTAL-FACE, TROCCINOX, SCOUTO3, ACTIVE, and AMMA appear to be well suited for such 
comparisons. Systematic comparisons with the set of all or most of the $\mathrm{LNO}_{\mathrm{x}}$-sensitive data obtained so far, both over land and ocean, in the tropics and at midlatitudes, over the last 2 to 3 decades, are still to be done. The results obtained with model fits up to now indicate best-estimates of the global $\mathrm{LNO}_{\mathrm{x}}$ value of about $2-8 \mathrm{Tg} \mathrm{a}^{-1}$ (or $5 \pm 3 \mathrm{Tg} \mathrm{a}^{-1}$ ). The possibility that the true value lies outside this range cannot be strictly excluded. The best value and the bounds may still vary when including additional data and improved models.

The models compute the $\mathrm{LNO}_{\mathrm{x}}$ production rate as a function of meteorological parameters. So far, the models do not account for all parameters identified as being important for affecting lightning and $\mathrm{LNO}_{\mathrm{x}}$ production for given thermodynamic and air composition conditions. Recent results show that the classical cloud-top-height (CTH) model does not capture the observed variability. The convective precipitation (CPR) model needs different scaling over oceans and continents and does not account for different lightning yields (number of lightning CG flashes per rain unit mass) at various latitudes. The convective updraft speed (UPD) and the CPR methods are based on subgrid-scale processes and hence are sensitive to details in the convective parameterisation. The $\mathrm{LNO}_{\mathrm{x}}$ parameterisation based on UPD covers better than $\mathrm{CTH}$ the land/ocean contrast. Both the UPD and $\mathrm{CPR}$ versions seem to simulate the variability of convection better than CTH. The results are also sensitive to the vertical emission profiles, and the best profile (or set of profiles for various storm types) has still to be determined. The model fit approach is only weakly sensitive to the IC/CG ratio in flash rates or production rates. Moreover, the $\mathrm{LNO}_{\mathrm{x}}$ sensitivity of the model results depends on mixing and the computed hydroxyl radicals converting lightning-induced $\mathrm{NO}$ to $\mathrm{NO}_{\mathrm{y}}$ and affecting other $\mathrm{NO}_{\mathrm{x}}$-dependent species such as $\mathrm{O}_{3}, \mathrm{CO}$ and others. An overestimate of the lifetime of $\mathrm{NO}_{\mathrm{x}}$ results in an underestimate of the $\mathrm{LNO}_{\mathrm{x}}$ source rate by the model fit. The quality of the models depends strongly on the grid resolution because of the large scale range between the fresh lightning plumes, narrow convective cloud cores and typical grid cell sizes. The background results depend also strongly on the accuracy of emission data from other sources. Even more demanding is the still open development of 3-D models accounting correctly for atmospheric electricity.

Model fits based on nitrate deposition data have been considered in several model studies, however only one early study made conclusions with respect to $\mathrm{LNO}_{\mathrm{x}}$. Because of large scatter of the deposition data and the difficulty in modelling dry and wet deposition fluxes, this method may not provide more accurate results than the concentration based approach. Previous model studies suggest that $5 \mathrm{Tg} \mathrm{a}^{-1}$ of $\mathrm{LNO}_{\mathrm{x}}$ do not contribute more than about $20-25 \%$ to nitrate deposition on average even in the tropics. The deposition fluxes are small in the polar regions and dependent on the complex transport and chemistry of long-living $\mathrm{NO}_{\mathrm{y}}$ components. Hence, an accurate analysis requires selection of regions and periods with higher $\mathrm{LNO}_{\mathrm{x}}$ share, preferably in the remote southern tropics.

So far, the globally-emitted $\mathrm{LNO}_{\mathrm{x}}$ nitrogen mass per year estimated in this study is in the range $2-8 \mathrm{Tg} \mathrm{a}^{-1}$. The uncertainty range is smaller than in early assessments, see Table 1. However, in spite of considerable progress, the uncertainty range is still large, only a little smaller than the range 1$8 \mathrm{Tg} \mathrm{a}^{-1}$ assessed by Lawrence et al. (1995). Though other $\mathrm{NO}_{\mathrm{x}}$ emissions (e.g., from soil or from biomass burning) may be uncertain to similar or even larger absolute scales, the $\mathrm{LNO}_{\mathrm{x}}$ uncertainty is still relatively large, and this is important because of the large impact of $\mathrm{LNO}_{\mathrm{x}}$ on upper tropospheric $\mathrm{NO}_{\mathrm{x}}$ and $\mathrm{O}_{3}$. Future work should aim to reduce the uncertainty range from presently $\pm 3 \mathrm{Tg} \mathrm{a}^{-1}$ to about $\pm 1 \mathrm{Tg} \mathrm{a}^{-1}$ or $20 \%$, whatever is smaller. In view of simple error estimates, this is still a very challenging goal.

Acknowledgements. We gratefully acknowledge contributions of data and figures, and helpful comments from V. Grewe, H. Höller, A. Schady, and H. Schlager at DLR; S. Beirle, Univ. Heidelberg; H.-D. Betz, Univ. Munich; D. J. Boccippio and H. J. Christian, NASA Marshall Space Flight Center, Alabama; D. Cecil, Univ. of Alabama in Huntsville; F. Dentener, JRC Ispra; J. Galloway, Univ. Virginia - Charlottesville; M. Lawrence, MPI for Chemistry, Mainz; R. V. Martin, Dalhousie Univ.; A. Richter, Univ. Bremen; and R. Thomas, New Mexico School of Mines and Technology. We thank for data and figures provided by the TROCCINOX team. We thank for library support by H. Krumbholz, S. Wohofsky and coworkers (DLR). The first author wishes to express his thanks to ILS for all her support. This work has been partially funded by the European Commission within TROCCINOX (contract EVK2-CT-2001-00122) and by the EU Networks of Excellence ACCENT and ECATS.

Edited by: M. G. Lawrence

\section{References}

Albritton, D. L., Liu, S. C., and Kley, D.: Global nitrate deposition from lightning, paper presented at Environmental impact of natural emissions, Air Pollution Control Association, Pittsburgh, Pennsylvania, Research Triangle Park, 1984.

Allen, D., Pickering, K., Stenchikov, G., Thompson, A., and Kondo, Y: A three-dimensional total odd nitrogen $\left(\mathrm{NO}_{\mathrm{y}}\right)$ simulation during SONEX using a stretched-grid chemical transport model, J. Geophys. Res., 105, 3851-3876, doi:10.1029/1999JD901029, 2000.

Allen, D. J. and Pickering, K. E.: Evaluation of lightning flash rate parameterizations for use in a global chemical transport model, J. Geophys. Res., 107, 4711, doi:10.1029/2002JD002066, 2002.

Anderson, N. F., Grainger, C. A., and Stith, J. L.: Characteristics of strong updrafts in precipitation systems over the central tropical Pacific Ocean and in the Amazon J. Appl. Meteorol., 44, 731738, doi:10.1175/JAM2231.1, 2005.

Andreae, M. O., Rosenfeld, D., Artaxo, P., Costa, A. A., Frank, G. P., Longo, K. M., and Silva-Dias, M. A. F.: Smoking rain clouds over the Amazon, Science, 303, 1337-1342, 2004. 
Anyamba, E., Williams, E., Susskind, J., Fraser-Smith, A., and Füllekrug, M.: The manifestation of the Madden-Julian oscillation in global deep convection and in the Schumann resonance intensity, J. Atmos. Sci., 57, 1029-1044, 2000.

Arakawa, A.: The cumulus parameterization problem: Past, present, and future, J. Climate, 17, 2493-2525, 2004.

Arnold, S. R., Chipperfield, M. P., and Blitz, M. A.: A threedimensional model study of the effect of new temperaturedependent quantum yields for acetone photolysis, J. Geophys. Res., 110, D22305, doi:10.1029/2005JD005998, 2005.

Atherton, C. S., Grotch, S., Parrish, D. D., Penner, J. E., and Walton, J. J.: The role of anthropogenic emissions of $\mathrm{NO}_{\mathrm{x}}$ on tropospheric ozone over the North Atlantic Ocean: a threedimensional, global model study, Atmos. Environ., 30, 17391749, 1996.

Attmannspacher, W. and Hartmannsgruber, R.: On extremely high values of ozone near the ground, Pure Appl. Geophys., 106, 1091-1096, 1973.

Baehr, J., Schlager, H., Ziereis, H., Stock, P., van Velthoven, P., Busen, R., Ström, J., and Schumann, U.: Aircraft observations of $\mathrm{NO}, \mathrm{NO}_{\mathrm{y}}, \mathrm{CO}$, and $\mathrm{O}_{3}$ in the upper troposphere from $60^{\circ} \mathrm{N}$ to $60^{\circ} \mathrm{S}$ - Interhemispheric differences at midlatitudes, Geophys. Res. Lett., 30, 52, doi:10.1029/2003gl016935, 2003.

Baker, M. B., Christian, H. J., and Latham, J.: A computational study of the relationships linking lightning frequency and other thundercloud parameters, Q. J. Roy. Meteor. Soc., 121, 15251548, 1995.

Baker, M. B., Blyth, A. M., Christian, H. J., Latham, J., Miller, K. L., and Gadian, A. M.: Relationships between lightning activity and various thundercloud parameters: satellite and modelling studies, Atmos. Res., 51, 221-236, 1999.

Barthe, C., Molinié, G., and Pinty, J.-P.: Description and first results of an explicit electrical scheme in a 3D cloud resolving model, Atmos. Res., 76, 95-113, 2005.

Barthe, C. and Pinty, J.-P.: Simulation of a supercellular storm using a three-dimensional mesoscale model with an explicit lightning flash scheme, J. Geophys. Res., 112, D06210, doi:10.1029/2006JD007484, 2007.

Barthe, C., Pinty, J.-P., and Mari, C.: Lightning-produced $\mathrm{NO}_{\mathrm{x}}$ in an explicit electrical scheme tested in a Stratosphere-Troposphere Experiment: Radiation, Aerosols, and Ozone case study, J. Geophys. Res., 112, D04302, doi:10.1029/2006JD007402, 2007.

Battan, L. J.: Some factors governing precipitation and lightning from convective clouds, J. Atmos. Sci., 22, 79-84, 1965.

Beck, J. P., Reeves, C. E., de Leeuw, F. A. A. M., and Penkett, S. A.: The effect of aircraft emissions on tropospheric ozone in the northern hemisphere, Atmos. Environ., 26A, 17-29, 1992.

Beirle, S.: Estimating source strengths and lifetime of nitrogen oxides from satellite data, 167 pp, Ph.D thesis, Ruperto-Carola University, Heidelberg, 2004.

Beirle, S., Platt, U., von Glasow, R., Wenig, M., and Wagner, T.: Estimate of nitrogen oxide emissions from shipping by satellite remote sensing, Geophys. Res. Lett., 31, L18102, doi:10.1029/2004GL020312, 2004a.

Beirle, S., Platt, U., Wenig, M., and Wagner, T.: $\mathrm{NO}_{\mathrm{x}}$ production by lightning estimated with GOME, Adv. Space Res., 34, 793-797, 2004b.

Beirle, S., Spichtinger, N., Stohl, A., et al.: Estimating the $\mathrm{NO}_{\mathrm{x}}$ produced by lightning from GOME and NLDN data: a case study in the Gulf of Mexico, Atmos. Chem. Phys., 6, 1075-1089, 2006, http://www.atmos-chem-phys.net/6/1075/2006/.

Benkovitz, C. M., Scholtz, M. T., Pacyna, J., Tarrasón, L., Dignon, J., Voldner, E. C., Spiro, P. A., Logan, J. A., and Graedel, T. E.: Global gridded inventories of anthropogenic emissions of sulfur and nitrogen, J. Geophys. Res., 101, 29 239-29254, doi:10.1029/96JD00126, 1996.

Berntsen, T. K. and Isaksen, I. S. A.: A global three-dimensional chemical transport model for the troposphere. Part 1: Model description and CO and ozone results, J. Geophys. Res., 102, 21 239-21 280, 1997.

Berntsen, T. K. and Isaksen, I. S. A.: Effects of lightning and convection on changes in tropospheric ozone due to $\mathrm{NO}_{\mathrm{x}}$ emissions from aircraft, Tellus, 51B, 766-788, 1999.

Bertram, T. H., Perring, A. E., Wooldridge, P. J., et al.: Direct measurements of the convective recycling of the upper troposphere, Science, 315, 816-820, doi:10.1126/science.1134548, 2007.

Betz, H.-D., Schmidt, K., Oettinger, P., and Wirz, M.: Lightning detection with 3-D discrimination of intracloud and cloud-to-ground discharges, Geophys. Res. Lett., 31, L11108, doi:10.1029/2004GL019821, 2004.

Betz, H.-D., Schmidt, K., Fuchs, B., Oettinger, W. P., and Höller, H.: Cloud lightning: Detection and utilization for total lightning measurements in the VLF/LF regime, J. Lightning Res., in press, 2007.

Bey, I., Jacob, D. J., Yantosca, R. M., Logan, J. A., Field, B. D., Fiore, A. M., Li, Q., Liu, H. Y., Mickley, L. J., and Schultz, M. G.: Global modeling of tropospheric chemistry with assimilated meteorology: Model description and evaluation, J. Geophys. Res., 106, 23 073-23 095, 2001.

Bhetanabhotla, M. N., Crowell, B. A., Coucouvinos, A., Hill, R. D., and Rinker, R. G.: Simulation of trace species production by lightning and corona discharge in moist air, Atmos. Environ., 19, 1391-1397, 1985.

Biagi, C. J., Cummins, K. L., Kehoe, K. E., and Krider, E. P.: National Lightning Detection Network (NLDN) performance in southern Arizona, Texas, and Oklahoma in 2003-2004, J. Geophys. Res., 112, D05208, doi:10.1029/2006JD007341, 2007.

Biazar, A. P. and McNider, R. T.: Regional estimates of lightning production of nitrogen oxides, J. Geophys. Res., 100, $22861-$ 22 874, doi:10.1029/95JD01735, 1995.

Boccippio, D., Koshak, J. W. J., and Blakeslee, R. J.: Performance assessment of the optical transient detector and lightning imaging sensor. Part I: Predicted diurnal variability, J. Atmos. Ocean. Technol., 19, 1318-1332, 2002.

Boccippio, D. J., Koshak, W., Blakeslee, R., Driscoll, K., Mach, D., Buechler, D., Boeck, W., Christian, H. J., and Goodman, S. J.: The Optical Transient Detector (OTD): instrument characteristics and cross-sensor validation, J. Atmos. Ocean. Technol., 17, 441-458, 2000.

Boccippio, D. J., Cummins, K. L., Christian, H. J., and Goodman, S. J.: Combined satellite- and surface-based estimation of the intracloud-cloud-to-ground lightning ratio over the continental United States, Mon. Wea. Rev., 129, 108-122, 2001.

Boccippio, D. J.: Lightning scaling relations revisited, J. Atmos. Sci., 59, 1086-1104, 2002.

Boeck, W. L., Suszcynsky, D. M., Light, T. E., Jacobson, A. R., Christian, H. J., Goodman, S. J., Buechler, D. E., and Guillen, J. L. L.: A demonstration of the capabilities of multisatellite ob- 
servations of oceanic lightning, J. Geophys. Res., 109, D17204, doi:10.1029/2003JD004491, 2004.

Boersma, K. F., Eskes, H. J., Meijer, E. W., and Kelder, H. M.: Estimates of lightning $\mathrm{NO}_{\mathrm{x}}$ production from GOME satellite observations, Atmos. Chem. Phys., 5, 2311-2331, 2005, http://www.atmos-chem-phys.net/5/2311/2005/.

Bond, D. W., Zhang, R., Tie, X., Brasseur, G., Huffines, G., Orville, R. E., and Boccippio, D. J.: $\mathrm{NO}_{\mathrm{x}}$ production by lightning over the continental United States, J. Geophys. Res., 106, $27701-$ 27 710, doi:10.1029/2000JD000191, 2001.

Bond, D. W., Steiger, S., Zhang, R., Tie, X., and Orville, R. E.: The importance of $\mathrm{NO}_{\mathrm{x}}$ production by lightning in the tropics, Atmos. Environ., 36, 1509-1519, 2002.

Bondiou-Clergerie, A., Lalande, P., and Roux, F.: "ORAGES": a dedicated sensor for detection, localisation and fine analysis of lightning flashes from space, Acta Astronautica, 55, 245-254, 2004.

Borra, J.-P., Roos, R. A., Renard, D., Lazar, H., Goldman, A., and Goldman, M.: Electrical and chemical consequences of point discharges in a forest during a mist and a thunderstorm, J. Phys. D: Appl. Phys., 30, 84-93, doi:10.1088/0022-3727/30/1/011, 1997.

Borucki, W. J. and Chameides, W. L.: Lightning: Estimates of the rates of energy dissipation and nitrogen fixation, Rev. Geophys. Space Phys., 22, 363-372, 1984.

Böttger, A., Ehhalt, D. H., and Gravenhorst, G.: Atmosphärische Kreisläufe von Stickoxiden und Ammoniak, 163 pp, Kernforschungsanlage Jülich, Jül-1558, 1978.

Boucher, O., Moulin, C., Belviso, S., et al.: DMS atmospheric concentrations and sulphate aerosol indirect radiative forcing: a sensitivity study to the DMS source representation and oxidation, Atmos. Chem. Phys., 3, 49-65, 2003, http://www.atmos-chem-phys.net/3/49/2003/.

Bousquet, P., Ciais, P., Miller, J. B., et al.: Contribution of anthropogenic and natural sources to atmospheric methane variability, Nature, 443, 439-443, doi:10.1038/nature05132, 2006.

Bouwman, A. F., Boumans, L. J. M., and Batjes, N. H.: Emissions of $\mathrm{N}_{2} \mathrm{O}$ and $\mathrm{NO}$ from fertilized fields: Summary of available measurement data, Global Biogeochem. Cycles, 16, 1058, doi:10.1029/2001GB001811, 2002.

Bovensmann, H., Burrows, J. P., Buchwitz, M., Frerick, J., Noeel, S., Rozanov, V. V., Chance, K. V., and Goede, A. P. H.: SCIAMACHY: mission objectives and measurement modes, J. Atmos. Sci., 56, 127-150, 1999.

Boville, B. A.: Middle atmosphere version of CCM2 (MACCM2): Annual cycle and interannual variability, J. Geophys. Res., 100, 9017-9040, 1995.

Bradshaw, J.: On the lightning source of tropospheric $\mathrm{NO}_{\mathrm{x}}$ : A tutorial critique, School of Earth and Atmospheric Sciences, Georgia Institute of Technology, Atlanta, GA (Copy available from D. Davis, School of Earth and Atmospheric Sciences, Georgia Institute of Technology, Atlanta, GA 30332-0340), 1996.

Bradshaw, J., Sandholm, S., and Talbot, R.: An update on reactive odd-nitrogen measurements made during recent NASA Global Tropospheric Experiment programs, J. Geophys. Res., 103, 19 129-19 148, 1998.

Bradshaw, J., Davis, D., Crawford, J., et al.: Photofragmentation two-photon laser-induced fluorescence detection of $\mathrm{NO}_{2}$ and NO: Comparison of measurements with model results based on airborne observations during PEM-Tropics A, Geophys. Res. Lett., 26, 471-474, 1999.

Bradshaw, J., Davis, D., Grodzinsky, G., Smyth, S., Newell, R., Sandholm, S., and Liu, S.: Observed distributions of nitrogen oxides in the remote free troposphere from the NASA Global Tropospheric Experiment programs, Rev. Geophys., 38, 61-116, doi:10.1029/1999RG900015, 2000.

Brasseur, G., Schultz, M., Granier, C., Saunois, M., Diehl, T., Botzlet, M., Roeckner, E., and Walters, S.: Impact of climate change on the future chemical composition of the global troposphere, J. Climate, 19, 3932-3951, doi:10.1175/JCLI3832.1, 2006.

Brasseur, G. P., Müller, J.-F., and Granier, C.: Atmospheric impact of $\mathrm{NO}_{\mathrm{x}}$ emissions by subsonic aircraft: A threedimensional model study, J. Geophys. Res., 101, 1423-1428, doi:10.1029/95JD02363, 1996.

Brasseur, G. P., Cox, R. A., Hauglustaine, D., Isaksen, I., Lelieveld, J., Lister, D. H., Sausen, R., Schumann, U., Wahner, A., and Wiesen, P.: European Scientific Assessment of the Atmospheric Effects of Aircraft Emissions, Atmos. Environ., 32, 2329-2418, 1998a.

Brasseur, G. P., Hauglustaine, D. A., Walters, S., Rasch, P. J., Mueller, J. F., Granier, C., and Tie, X. X.: MOZART, a global chemical transport model for ozone and related chemical tracers. Part 1: Model description, J. Geophys. Res., 103, 28 265-28 289. 1998b.

Brenninkmeijer, C., Slemr, F., Koeppel, C., et al.: Analyzing atmospheric trace gases and aerosols using passenger aircraft, EOS, 86, 77-88, 2005.

Brenninkmeijer, C. A. M., Crutzen, P., Boumard, F., et al.: Civil aircraft for the regular investigation of the atmosphere based on an instrumented container: the new CARIBIC system, Atmos. Chem. Phys. Discuss., 7, 5277-5339, 2007,

http://www.atmos-chem-phys-discuss.net/7/5277/2007/.

Brooks, C. E. P.: The distribution of thunderstorms over the globe, Geophys. Memor., 3, 147-164, 1925.

Brooks, H. E., Lee, J. W., and Craven, J. P.: The spatial distribution of severe thunderstorm and tornado environments from global reanalysis data, Atmos. Res., 67-68, 73-94, 2003.

Browning, K. A.: Organization of clouds and precipitation in extratropical cyclones, in: Extratropical Cyclones - The Erik Palmén Memorial Volume, edited by: Newton, C. and Holopainen, E. O., pp. 129-153, Amer. Met. Soc., Boston, 1990.

Brühl, C., Pöschl, U., Crutzen, P. J., and Steil, B.: Acetone and PAN in the upper troposphere: impact on ozone production from aircraft emissions, Atmos. Environ., 34, 3931-3938, 2000.

Brunner, D.: One-year climatology of nitrogen oxides and ozone in the tropopause region, $181 \mathrm{pp}$, Eidgenössische Technische Hochschule, Zürich, 1998.

Brunner, D., Staehelin, J., and Jeker, D.: Large-scale nitrogen oxide plumes in the tropopause region and implications for ozone, Science, 282, 1305-1308, 1998.

Brunner, D., Staehelin, J., Jeker, D., Wernli, H., and Schumann, U.: Nitrogen oxides and ozone in the tropopause region of the Northern Hemisphere: Measurements from commercial aircraft in 1995/1996 and 1997, J. Geophys. Res., 106, 27 673-27 700, doi:10.1029/2001JD900239, 2001.

Brunner, D., Staehelin, J., Rogers, H. L., et al.: An evaluation of the performance of chemistry transport models by comparison with research aircraft observations. Part 1: Concepts and overall 
model performance, Atmos. Chem. Phys., 3, 1609-1631, 2003, http://www.atmos-chem-phys.net/3/1609/2003/.

Brunner, D., Staehelin, J., Rogers, H. L., et al.: An evaluation of the performance of chemistry transport models - Part 2: Detailed comparison with two selected campaigns, Atmos. Chem. Phys., 5, 107-129, 2005,

http://www.atmos-chem-phys.net/5/107/2005/.

Bucsela, E. J., Celarier, E. A., Wenig, M. O., Gleason, J. F., Veefkind, J. P., Boersma, K. F., and Brinksma, E.: Algorithm for $\mathrm{NO}_{2}$ vertical column retrieval from the Ozone Monitoring Instrument, IEEE Trans. Geosci. Rem. Sens., 44, 1245-1258, 2006.

Buettner, K., Businger, J., and Charlson, R.: Discussion of paper by J. Kroening and E. P. Nay, "Atmospheric Ozone"; and authors reply, J. Geophys. Res., 67, 4508-4511, 1962.

Burrows, J. P., Weber, M., Buchwitz, M., et al.: The Global Ozone Monitoring Experiment (GOME): mission concept and first scientific results, J. Atmos. Sci., 56, 151-175, 1999.

Carey, L. D. and Rutledge, S. A.: Characteristics of cloud-toground lightning in severe and nonsevere storms over the central Unites States from 1989-1998, J. Geophys. Res., 180, 4483, doi:10.1029/2002JD002951, 2003.

Carroll, M. A. and Thompson, A. M.: $\mathrm{NO}_{\mathrm{x}}$ in the non-urban troposphere, in: Progress and Problems in Atmospheric Chemistry, Advanced Series in Physical Chemistry - Vol. 3, edited by: Barker, J. R., pp. 198-255, World Scientific Publishing Company, Singapore, 1995.

Cavendish, H.: Experiments on air, Philosophical Transactions, 75, 372 pp, 1785.

Cecil, D. J., Goodman, S. J., Boccippio, D. J., Zipser, E. J., and Nesbitt, S. W.: Three years of TRMM precipitation features. Part I: Radar, radiometric, and lightning characteristics, Mon. Wea. Rev., 133, 543-566, 2005.

Cecil, D. J.: Global distributions of thunderstorms based on 7+ years of TRMM, paper presented at AMS Conf. Meteorol. Appl. Lightn. Data, Atlanta, GA (USA), 28 January-3 February, http: //ams.confex.com/ams/pdfpapers/105167.pdf, 2006.

Chaboureau, J.-P. and Bechtold, P.: Statistical representation of clouds in a regional model and the impact on the diurnal cycle of convection during Tropical Convection, Cirrus and Nitrogen Oxides (TROCCINOX), J. Geophys. Res., 110, D17103, doi:10.1029/2004JD005645, 2005.

Chaboureau, J. P., Cammas, J.-P., Duron, J., Mascart, P. J., Sitnikov, N. M., and Voessing, H.-J.: A numerical study of tropical crosstropopause transport by convective overshoots, Atmos. Chem. Phys., 7, 1731-1740, 2007, http://www.atmos-chem-phys.net/7/1731/2007/.

Chalita, S., Hauglustaine, D. A., Le Treut, H., and Mueller, J.-F.: Radiative forcing due to increased tropospheric ozone concentrations, Atmos. Environ., 30, 1641-1646, 1990.

Chameides, W. and Walker, J. C. G.: A photochemical theory of tropospheric ozone, J. Geophys. Res., 78, 8751-8760, 1973.

Chameides, W. L., Stedman, D. H., Dickerson, R. R., Rusch, D. W., and Cicerone, R. J.: $\mathrm{NO}_{\mathrm{x}}$ production in lightning, J. Atmos. Sci., 34, 143-149, 1977.

Chameides, W. L.: Effect of variable energy input on nitrogen fixation in instantaneous linear discharges, Nature, 277, 123-125, 1979a.

Chameides, W. L.: The implications of CO production in electrical discharges, Geophys. Res. Lett., 6, 287-290, 1979 b.
Chameides, W. L.: The role of lightning in the chemistry of the atmosphere, in: Earth's Electrical Environment, edited by: Krider, E. P. and Roble, R. G., pp. 70-77, National Academy Press, Wash., D.C., 1986.

Chameides, W. L., Davies, D. D., Bradshaw, J., Rodgers, M., Sandholm, S., and Bai, D. B.: An estimate of the $\mathrm{NO}_{\mathrm{x}}$ production rate in electrified clouds based on NO observations from GTE/CITE 1 fall 1983 field operation, J. Geophys. Res., 92, 2153-2156, 1987.

Chatfield, R. B. and Crutzen, P. J.: Sulfur dioxide in remote oceanic air: Cloud transport of reactive precursors, J. Geophys. Res., 89, 7111-7132, 0148-0227/84/004D-0378, 1984.

Chatfield, R. B., Guan, H., Thompson, A. M., and Witte, J. C.: Convective lofting links Indian Ocean air pollution to paradoxical South Atlantic ozone maxima, Geophys. Res. Lett., 31, L06103, doi:10.1029/2003GL018866, 2004.

Choi, Y., Elliott, S., Simpson, I. J., Blake, D. R., Colman, J. J., Dubey, M. K., Meinardi, S., Rowland, F. S., Shirai, T., and Smith, F. A.: Survey of whole air data from the second airborne Biomass Burning and Lightning Experiment using principal component analysis, J. Geophys. Res., 108, 4163, doi:10.1029/2002JD002841, 2003.

Choi, Y., Wang, Y., Zeng, T., Martin, R. V., Kurosu, T. P., and Chance, K.: Evidence of lightning $\mathrm{NO}_{\mathrm{X}}$ and convective transport of pollutants in satellite observations over North America, Geophys. Res. Lett., 32, L02805, doi:10.1029/2004GL021436, 2005.

Christian, H. J., Blakeslee, R. J., Boccippio, D. J., et al.: Global frequency and distribution of lightning as observed from space by the Optical Transient Detector, J. Geophys. Res., 108, 4005, doi:10.1029/2002JD002347, 2003.

Christian, H. J. and Petersen, W.: Global lightning activity (2005 lightning), paper presented at AMS Conference on Meteorological Applications of Lightning Data, 2005.

Clarke, A. D., Eisele, F., Kapustin, V. N., Moore, K., Tanner, D., Mauldin, L., Litchy, M., Lienert, B., Carroll, M. A., and Albercook, G.: Nucleation in the equatorial free troposphere: Favorable environments during PEM-Tropics, J. Geophys. Res., 104, 5735-5744, 10.1029/98JD02303, 1999.

Clarke, J. F. and Griffing, G. W.: Aircraft observations of extreme ozone concentrations near thunderstorms, Atmos. Environ., 19, 1175-1179, 1985.

Clemitshaw, K. C.: A review of instrumentation and measurement techniques for ground-based and airborne field studies of gasphase tropospheric chemistry, Critical Revs. Environ. Sci. Technol., 34, 1-108, doi:10.1080/10643380490265117, 2004.

Collins, W. J., Stevenson, D. S., Johnson, C. E., and Derwent, R. G.: Tropospheric ozone in a global-scale three-dimensional Lagrangian model and its response to $\mathrm{NO}_{\mathrm{x}}$ emission controls, J. Atmos. Chem., 26, 223-274, 1997.

Collins, W. J., Derwent, R. G., Garnier, B., Johnson, C. E., Sanderson, M. G., and Stevenson, D. S.: The effect of stratospheretroposphere exchange on the future tropospheric ozone trend, J. Geophys. Res., 108, 8528, doi:10.1029/2002JD002617, 2003.

Cook, D. R., Liaw, Y. P., Sisterson, D. L., and Miller, N. L.: Production of nitrogen oxides by a large spark generator, J. Geophys. Res., 105, 7103-7110, doi:10.1029/1999JD901138, 2000.

Cooper, O. R., Stohl, A., Trainer, M., et al.: Large upper tropospheric ozone enhancements above mid-latitude North America during summer: In situ evidence from the IONS and MOZAIC 
ozone measurement network, J. Geophys. Res., 111, D24S05, doi:10.1029/2006JD007306, 2006.

Cooray, V.: Energy dissipation in lightning flashes, J. Geophys. Res., 102, 21 401-21 410, 1997.

Cooray, V. and Rahman, M.: Efficiencies for production of $\mathrm{NO}_{\mathrm{x}}$ and $\mathrm{O}_{3}$ by streamer discharges in air at atmospheric pressure, $\mathrm{J}$. Electrostat., 63, 977-983, 2005.

Coppens, F., Berton, R., Bondiou-Clergerie, A., and Gallimberti, I.: Theoretical estimate of $\mathrm{NO}_{\mathrm{x}}$ production in lightning corona, J. Geophys. Res., 103, 10 769-10 785, doi:10.1029/97JD02848, 1998.

Cornell, S. E., Jickells, T. D., Cape, J. N., Rowland, A. P., and Duce, R. A.: Organic nitrogen deposition on land and coastal environments: A review of methods and data, Atmos. Environ., 37, 2173-2191, 2003.

Cotton, W. R. and Anthes, R. A.: Storm and Cloud Dynamics, 883 pp., Academic Press, San Diego, CA, 1989.

Cotton, W. R., Alexander, G. D., Hertenstein, R., Walko, R. L., McAnelly, R. L., and Nicholls, M.: Cloud venting - A review and some new global annual estimates, Earth-Sci. Rev., 39, 169205, 1995.

Crawford, J., Davis, D., Chen, G., et al.: Photostationary state analysis of the $\mathrm{NO}_{2}-\mathrm{NO}$ system based on airborne observations from the western and central North Pacific, J. Geophys. Res., 101, 2053-2072, 1996.

Crawford, J., Davis, D., Olson, J., et al.: Evolution and chemical consequences of lightning-produced $\mathrm{NO}_{\mathrm{x}}$ observed in the North Atlantic upper troposphere, J. Geophys. Res., 105, 1979519810, doi:10.1029/2000JD900183, 2000.

Crutzen, P. J.: The influence of nitrogen oxides on the atmospheric ozone content, Q. J. Roy. Meteor. Soc., 96, 320-325, 1970.

Crutzen, P. J.: Photochemical reactions initiated by and influencing ozone in unpolluted tropospheric air, Tellus, 26, 47-57, 1974.

Crutzen, P. J.: The role of $\mathrm{NO}$ and $\mathrm{NO}_{2}$ in the chemistry of the troposphere and stratosphere, Ann. Rev. Earth Planet. Sci., 7, 443$472,1979$.

Crutzen, P. J. and Zimmermann, P. H.: The changing photochemistry of the troposphere, Tellus, 43AB, 136-151, 1991.

Crutzen, P. J., Lawrence, M. G., and Pöschl, U.: On the background photochemistry of tropospheric ozone, Tellus, 51AB, 123-146, 1999.

Cummins, K. L., Murphy, M. J., Bardo, E. A., Hiscox, W. L., Pyle, R. B., and Pifer, A. E.: A combined TOA/MDF technology upgrade of the U.S. National Lightning Detection Network, J. Geophys. Res., 102, 9035-9044, 1998.

Dai, A.: Global precipitation and thunderstorm frequencies. Part II: Diurnal variations, J. Climate, 14, 1112-1128, 2001.

Dameris, M., Grewe, V., Köhler, I., Sausen, R., Brühl, C., Grooß, J. U., and Steil, B.: Impact of aircraft $\mathrm{NO}_{\mathrm{x}}$ emissions on tropospheric and stratospheric ozone. Part II: 3-D model results, Atmos. Environ., 32, 3185-3199, 1998.

Dameris, M., Grewe, V., Ponater, M., et al.: Long-term changes and variability in a transient simulation with a chemistry-climate model employing realistic forcing, Atmos. Chem. Phys., 5, 2121-2145, 2005, http://www.atmos-chem-phys.net/5/2121/2005/.

Davis, D. D., Bradshaw, J. D., Rodgers, M. O., Sandholm, S. T., and KeSheng, S.: Free tropospheric and boundary layer measurements of NO over the central and eastern North Pacific Ocean, J.
Geophys. Res., 92, 2049-2070, 1987.

Davis, D. D., Crawford, J., Chen, G., et al.: Assessment of ozone photochemistry in the western North Pacific as inferred from PEM-West A observations during the fall 1991, J. Geophys. Res., 101, 2111-2134, doi:10.1029/95JD02755, 1996.

Dawson, G. A.: Nitrogen fixation by lightning, J. Atmos. Sci., 37, 174-178, 1980.

DeCaria, A. J., Pickering, K. E., Stenchikov, G. L., Scala, J. R., Stith, J. L., Dye, J. E., Ridley, B. A., and Laroche, P.: A cloud-scale model study of lightning-generated $\mathrm{NO}_{\mathrm{x}}$ in an individual thunderstorm during STERAO-A, J. Geophys. Res., 105, 11 601-11 616, 2000.

DeCaria, A. J., Pickering, K. E., Stenchikov, G. L., and Ott, L. E.: Lightning-generated $\mathrm{NO}_{\mathrm{x}}$ and its impact on tropospheric ozone production: A three-dimensional modeling study of a Stratosphere-Troposphere Experiment: Radiation, Aerosols and Ozone (STERAO-A) thunderstorm, J. Geophys. Res., 110, 1-13, doi:10.1029/2004JD005556, 2005.

Defer, E., Blanchet, P., Thery, C., Laroche, P., Dye, J. E., Venticinque, M., and Cummins, K. L.: Lightning activity for the July 10, 1996, storm during the Stratosphere-Troposphere Experiment: Radiation, Aerosol, and Ozone-A (STERAO-A) experiment, J. Geophys. Res., 106, 10 151-10 172, 2001.

Deierling, W., Latham, J., Petersen, W. A., Ellis, S. M., and Christian Jr., H. J.: On the relationship of thunderstorm ice hydrometeor characteristics and total lightning measurements, Atmos. Res., 76, 114-126, 2005.

Dentener, F., Drevet, J., Lamarque, J. F., et al.: Nitrogen and sulfur deposition on regional and global scales: A multimodel evaluation, Global Biogeochem. Cycles, 20, GB4003, doi:10.1029/2005GB002672, 2006.

Dentener, F. J. and Crutzen, P. J.: Reaction of $\mathrm{N}_{2} \mathrm{O}_{5}$ on tropospheric aerosols: impact on the global distributions of $\mathrm{NO}_{\mathrm{x}}, \mathrm{O}_{3}$, and $\mathrm{OH}$, J. Geophys. Res., 98, 7149-7163, 1993.

Dentener, F. J. and Crutzen, P. J.: A three-dimensional model of the global ammonia cycle, J. Atmos. Chem., 19, 331-369, 1994.

Dentener, F. J.: Global Maps of Atmospheric Nitrogen Deposition, 1860, 1993, and 2050. Data set, (http://daac.ornl.gov/), Oak Ridge National Laboratory Distributed Active Archive Center, Oak Ridge, Tennessee, USA, 2006.

Dickerson, R. R.: Measurements of reactive nitrogen compounds in the free troposphere, Atmos. Environ., 18, 2585-2593, 1984.

Dickerson, R. R., Huffman, G. J., Luke, W. T., et al.: Thunderstorms: An important mechanism in the transport of air pollutants, Science, 235, 460-465, 1987.

Dobson, G. M. B., Brewer, A. W., and Cwilong, B. M.: Meteorology of the lower stratosphere, Proc. Roy. Soc. London, 185, 144, 1946.

Doherty, R. M., Stevenson, D. S., Johnson, C. E., Collins, W. J., and Sanderson, M. G.: Tropospheric ozone and El Niño-Southern Oscillation: Influence of atmospheric dynamics, biomass burning emissions, and future climate change, J. Geophys. Res., 111, D19304, doi:10.1029/2005JD006849, 2006.

Donohoe, K. G., Shair, F. H., and Wulf, O. R.: Production of $\mathrm{O}_{3}$, $\mathrm{NO}$, and $\mathrm{N}_{2} \mathrm{O}$ in a pulsed discharge at $1 \mathrm{~atm}$, Ind. Eng. Chem. Fundam., 16, 208-215, 1977.

Dotzek, N., Höller, H., and Théry, C.: VHF-Interferometry and radar observation: Implications for nitrogen oxides production, in: EULINOX - The European Lightning Nitrogen Oxides Ex- 
periment, edited by: Höller, H. and Schumann, U., pp. 147-166, Deutsches Zentrum für Luft- und Raumfahrt, Köln, Report DLRFB 2000-28, 2000.

Drapcho, D. L., Sisterson, D., and Kumar, R.: Nitrogen fixation by lightning activity in a thunderstorm, Atmos. Environ., 17, 729734, 1983.

Drummond, J. W., Ehhalt, D. H., and Volz, A.: Measurements of nitric oxide between $0-12 \mathrm{~km}$ altitude and $67^{\circ} \mathrm{N}$ to $60^{\circ} \mathrm{S}$ latitude obtained during STRATOZ III, J. Geophys. Res., 93, 15832 $15849,1988$.

Duncan, B. N., Bey, I., Chin, M., Mickley, L. J., Fairlie, T. D., Martin, R. V., and Matsueda, H.: Indonesian wildfires of 1997: Impact on tropospheric chemistry, J. Geophys. Res., 108, 4458, doi:10.1029/2002JD003195, 2003.

Durden, S. L., Meagher, J. P., and Haddad, Z. S.: Satellite observations of spatial and interannual variability of lightning and radar reflectivity, Geophys. Res. Lett., 31, L18111, doi:10.1029/2004GL020384, 2004.

Dwyer, J. R.: The initiation of lightning by runaway air breakdown, Geophys. Res. Lett., 32, L20808, doi:10.1029/2005GL023975, 2005.

Dye, J. E., Ridley, B. A., Skamarock, W., et al.: An overview of the Stratospheric-Tropospheric Experiment: Radiation, Aerosols, and Ozone (STERAO)-Deep Convection experiment with results for the July 10, 1996 storm, J. Geophys. Res., 105, 10023 10045,2000

Edwards, D. P., Lamarque, J.-F., Attie, J. L., et al.: Tropospheric ozone over the Tropical Atlantic: A satellite perspective, J. Geophys. Res., 108, 4237, doi:10.1029/2002JD002927, 2003.

Ehhalt, D. H. and Drummond, J. W.: The tropospheric cycle of $\mathrm{NO}_{\mathrm{x}}$, in: Chemistry of the Unpolluted and Polluted Troposphere, edited by: Georgii, H. W. and Jaeschke, W., pp. 219-251, D. Reidel Publ. Co., 1982.

Ehhalt, D. H., Rohrer, F., and Wahner, A.: Sources and distribution of $\mathrm{NO}_{\mathrm{x}}$ in the upper troposphere at northern mid-latitudes, J. Geophys. Res., 97, 3725-3738, doi:10.1029/91JD03081, 1992.

Ehhalt, D. H. and Rohrer, F.: The impact of commercial aircraft on tropospheric ozone, in: The Chemistry of the Atmosphere - Oxidants and Oxidation in the Earth's Atmosphere, 7th BOC Priestley Conference, Lewisburg, Pennsylvania, edited by: Brandy, A. R., pp. 105-120, Woodhead Publishing Limited, ISBN 185573 798 1, Cambridge, 1994.

Ehhalt, D. H.: Gas phase chemistry of the troposphere, in: Global Aspects of Atmospheric Chemistry, edited by: Zellner, R., pp. 21-109, Springer, Darmstadt, Germany, 1999.

Emmons, L. K., Carroll, M. A., Hauglustaine, D. A., et al.: Climatologies of $\mathrm{NO}_{\mathrm{x}}$ and $\mathrm{NO}_{\mathrm{y}}$ : a comparison of data and models, Atmos. Environ., 31, 1851-1904, 1997.

Emmons, L. K., Hauglustaine, D. A., Mueller, J.-F., Carroll, M. A., Brasseur, G. P., Brunner, D., Staehelin, J., Thouret, V., and Marenco, A.: Data composites of airborne observations of tropospheric ozone and its precursors, J. Geophys. Res., 105, $20497-$ 20 538, 2000.

Engel, A., Bönisch, H., Brunner, D., et al.: Highly resolved observations of trace gases in the lowermost stratosphere and upper troposphere from the SPURT project: an overview, Atmos. Chem. Phys., 6, 283-301, 2006,

http://www.atmos-chem-phys.net/6/283/2006/.

Erle, F., Pfeilsticker, K., and Platt, U.: On the influence of tropo- spheric clouds on zenith-scattered-light measurements of stratospheric species, Geophys. Res. Lett., 22, 2725-2728, 1995.

Eyers, C. J., Addleton, D., Atkinson, K., et al.: AERO2k Global Aviation Emissions Inventories for 2002 and 2025, QinetiQ for European Commission under Contract No. G4RD-CT-200000382, Farnborough, Hampshire, GU14 0LX, 2005.

Eyring, V., Köhler, H. W., van Aardenne, J., and Lauer, A.: Emissions from international shipping: 1 . The last 50 years, J. Geophys. Res., 110, D17305, doi:10.1029/2004JD005619, 2005.

Eyring, V., Butchart, N., Waugh, D. W., et al.: Assessment of temperature, trace species, and ozone in chemistry-climate model simulations of the recent past, J. Geophys. Res., 111, D22308, doi:10.1029/2006JD007327, 2006.

Fahey, D. W., Eubank, C. S., Hübler, G., and Fehsenfeld, F. C.: Evaluation of a catalytic reduction method for the measurement of total reactive odd-nitrogen $\mathrm{NO}_{\mathrm{y}}$ in the atmosphere, J. Atmos. Chem., 3, 435-468, 1985.

Fehr, T., Höller, H., and Huntrieser, H.: Model study on production and transport of lightning-produced $\mathrm{NO}_{\mathrm{x}}$ in a EULINOX supercell storm, J. Geophys. Res., 109, 1-17, doi:10.1029/2003JD003935, 2004.

Fehsenfeld, F. C. and Liu, S. C.: Tropospheric ozone: Distribution and sources., in: Global Atmospheric Chemical Change, edited by: Hewitt, C. N. and Sturges, W. T., pp. 169-231, Elsevier Applied Sciences, London and New York, 1993.

Fehsenfeld, F. C., Ancellet, G., Bates, T. S., et al.: International Consortium for Atmospheric Research on Transport and Transformation (ICARTT): North America to Europe - Overview of the 2004 summer field study, J. Geophys. Res., 111, D23S01, doi:10.1029/2006JD007829, 2006.

Fierro, A. O., Gilmore, M. S., Mansell, E. R., Wicker, L. J., and Straka, J. M.: Electrification and lightning in an idealized boundary-crossing supercell simulation of 2 June 1995, Mon. Wea. Rev., 134, 3149-3172, 2006.

Finke, U. and Hauf, T.: The characteristics of lightning occurrence in southern Germany, Beitr. Phys. Atmosph., 69, 361-374, 1996.

Fiore, A. M., Horowitz, L. W., Dlugokencky, E. J., and West, J. J.: Impact of meteorology and emissions on methane trends, 1990-2004, Geophys. Res. Lett., 33, L12809, doi:10.1029/2006GL026199, 2006.

Fishman, J., Solomon, S., and Crutzen, P. J.: Observational and theoretical evidence in support of a significant in-situ photochemcial source of tropospheric ozone, Tellus, 31, 432-446, 1979.

Fishman, J., Hoell Jr., J. M., Bendura, R. D., McNeal, R. J., and Kirchhoff, V. W. J. H.: NASA GTE TRACE A experiment (September-October 1992): overview, J. Geophys. Res., 101, $23865-23879,1996$.

Flatøy, F. and Hov, O.: $\mathrm{NO}_{\mathrm{x}}$ from lightning and the calculated chemical composition of the free troposphere, J. Geophys. Res., 102, $21373-21381,1997$.

Franklin, B.: Experiments and Observations of Electricity; Made at Philadelphia in America, 5th ed., 514 pp., F. Newberry, London, 1774.

Franzblau, E. and Popp, C. J.: Nitrogen oxides produced from lightning, J. Geophys. Res., 94, 11089-11104, doi:10.1029/89JD00694, 1989.

Franzblau, E.: Electrical discharges involving formation of NO, $\mathrm{NO}_{2}, \mathrm{HNO}_{3}$, and $\mathrm{O}_{3}$, J. Geophys. Res., 96, 22 337-22 345, 1991 
Fraser, A., Goutail, F., McLinden, C. A., Melo, S. M. L., and Strong, K.: Lightning-produced $\mathrm{NO}_{2}$ observed by two ground-based UV-visible spectrometers at Vanscoy, Saskatchewan in August 2004, Atmos. Chem. Phys., 7, 1683-1692, 2007, http://www.atmos-chem-phys.net/7/1683/2007/.

Fuglestvedt, J. S., Berntsen, T. K., Isaksen, I. S. A., Mao, H., Liang, X.-Z., and Wang, W.-C.: Climatic forcing of nitrogen oxides through changes in tropospheric ozone and methane; global 3D model studies, Atmos. Environ., 33, 961-977, 1999.

Füllekrug, M. and Fraser-Smith, A. C.: Global lightning and climate variability inferred from ELF magnetic field variations, Geophys. Res. Lett., 24, 2411-2414, 1997.

Füllekrug, M., Mareev, E. A., and Rycroft, M. J. (Eds.): Sprites, Elves and Intense Lightning Discharges, 398 pp., Springer, Dordrecht, The Netherlands, 2006.

Funke, B., López-Puertas, M., von Clarmann, T., et al.: Retrieval of stratospheric $\mathrm{NO}_{\mathrm{x}}$ from 5.3 and $6.2 \mu \mathrm{m}$ nonlocal thermodynamic equilibrium emissions measured by Michelson Interferometer for Passive Atmospheric Sounding (MIPAS) on Envisat, J. Geophys. Res., 110, D09302, doi:10.1029/2004JD005225, 2005.

Gallardo, L. and Cooray, V.: Could cloud-to-cloud discharges be as effective as cloud-to-ground discharges in producing $\mathrm{NO}_{\mathrm{x}}$ ?, Tellus, 48B, 641-651, 1996.

Gallardo, L. and Rodhe, H.: Oxidized nitrogen in the remote Pacific: the role of electrical discharges over the oceans, J. Atmos. Chem., 26, 147-168, 1997.

Galloway, J. M., Dentener, F. J., Capone, D. G., et al.: Nitrogen Cycles: Past, Present and Future, Biogeochemistry, 70, 153-226, 2004.

Galloway, J. N., Likens, G. E., Keene, W. C., and Miller, J. M.: The composition of precipitation in remote areas of the world, J. Geophys. Res., 87, 8771-8786, 1982.

Gauss, M., Myhre, G., Isaksen, I. S. A., et al.: Radiative forcing since preindustrial times due to ozone change in the troposphere and the lower stratosphere, Atmos. Chem. Phys., 6, 575-599, 2006 , http://www.atmos-chem-phys.net/6/575/2006/.

Gauthier, M. L., Petersen, W. A., Carey, L. D., and Christian Jr., H. J.: Relationship between cloud-to-ground lightning and precipitation ice mass: A radar study over Houston, Geophys. Res. Lett., 33, L20803, doi:10.1029/2006GL027244, 2006.

Giannakopoulos, C., Chipperfield, M. P., Law, K. S., and Pyle, J. A.: Validation and intercomparison of wet and dry deposition schemes using $210 \mathrm{~Pb}$ in a global three-dimensional off-line chemical transport model, J. Geophys. Res., 104, 23 761-23 784, 1999.

Giorgi, F. and Chameides, W. L.: The rainout parameterization in a photochemical model, J. Geophys. Res., 90, 7872-7880, 1985.

Goldenbaum, G. C. and Dickerson, R. R.: Nitric oxide production by lightning discharges, J. Geophys. Res., 98, 18333-18338, 1993.

Goodman, S. J., Christian, H. J., and Rust, W. D.: A comparison of the optical pulse characteristics of intracloud and cloud-toground lightning as observed above clouds, J. Appl. Meteorol., 27, 1369-1381, 1988.

Goodman, S. J., Buechler, D. E., Knupp, K., Driscoll, K., and McCaul Jr., E. W.: The 1997-98 El Nino event and related wintertime lightning variations in the Southeastern United States, Geophys. Res. Lett., 27, 541-544, 2000.
Granier, C., Petron, G., Müller, J.-F., and Brasseur, G.: The impact of natural and anthropogenic hydrocarbons on the tropospheric budget of carbon monoxide, Atmos. Environ., 34, 5255-5270, 2000.

Granier, C., Artaxo, P., and Reeves, C. E. (Eds.): Emissions of Atmospheric Trace Compounds, 546 pp., Kluwer Acad. Publ., Dordrecht, 2004.

Gregory, G. L., Browell, E. V., and Warren, L. S.: Boundary layer ozone: an airborne survey above the Amazon Basin, J. Geophys. Res., 93, 1452-1468, 1988.

Gregory, G. L., Fuelberg, H. E., Longmore, S. P., Anderson, B. E., Collins, J. E., and Blake, D. R.: Chemical characteristics of tropospheric air over the tropical South Atlantic Ocean: Relationship to trajectory history, J. Geophys. Res., 101, 23 957-23972, 1996.

Gregory, G. L., Merrill, J. T., Shipham, M. C., Blake, D. R., Sachse, G. W., and Singh, H. B.: Chemical characteristics of tropospheric air over the Pacific Ocean as measured during PEM-West B: relationship to Asian outflow and trajectory history, J. Geophys. Res., 102, 28 275-28 285, 1997.

Gregory, G. L., Westberg, D. J., Shipham, M. C., et al.: Chemical characteristics of Pacific tropospheric air in the region of the Intertropical Convergence Zone and South Pacific Convergence Zone, J. Geophys. Res., 104, 5677-5696, 1999.

Grenfell, J. L., Shindell, D. T., and Grewe, V.: Sensitivity studies of oxidative changes in the troposphere in 2100 using the GISS GCM, Atmos. Chem. Phys., 3, 1267-1283, 2003, http://www.atmos-chem-phys.net/3/1267/2003/.

Grewe, V. and Dameris, M.: Calculating the global mass exchange between stratosphere and troposphere, Ann. Geophys., 14, 431442, 1996, http://www.ann-geophys.net/14/431/1996/.

Grewe, V., Brunner, D., Dameris, M., Grenfell, J. L., Hein, R., Shindell, D., and Staehelin, J.: Origin and variability of upper tropospheric nitrogen oxides and ozone at northern mid-latitudes, Atmos. Environ., 35, 3421-3433, 2001.

Grewe, V., Dameris, M., Fichter, C., and Sausen, R.: Impact of aircraft $\mathrm{NO}_{\mathrm{x}}$ emissions. Part 1: Interactively coupled climatechemistry simulations and sensitivities to climate-chemistry feedback, lightning and model resolution, Meteorol. Z., 11, 177186, 2002.

Grewe, V., Shindell, D. T., and Eyring, V.: The impact of horizontal transport on the chemical composition in the tropopause region: lightning $\mathrm{NO}_{\mathrm{x}}$ and streamers, Adv. Space Res., 33, 1058-1061, 2004.

Grewe, V.: Impact of climate variability on tropospheric ozone, Sci. Total Environ., 374, 167-181, doi:10.1016/j.scitotenv.2007.01.032, 2007.

Griffing, G. W.: Ozone and oxides of nitrogen production during thunderstorms, J. Geophys. Res., 82, 943-950, 1977.

Grooß, J.-U., Brühl, C., and Peter, T.: Impact of aircraft emissions on tropospheric and stratospheric ozone. Part I: Chemistry and 2-D model results, Atmos. Environ., 32, 3173-3184, 1998.

Grooß, J.-U. and Russell III, J. M.: Technical note: A stratospheric climatology for $\mathrm{O}_{3}, \mathrm{H}_{2} \mathrm{O}, \mathrm{CH}_{4}, \mathrm{NO}_{\mathrm{x}}, \mathrm{HCl}$ and $\mathrm{HF}$ derived from HALOE measurements, Atmos. Chem. Phys., 5, 2797-2807, 2005 , http://www.atmos-chem-phys.net/5/2797/2005/.

Gungle, B. and Krider, E. P.: Cloud-to-ground lightning and surface 
rainfall in warm-season Florida thunderstorms, J. Geophys. Res., 111, D19203, doi:10.1029/2005JD006802, 2006.

Gurevich, A. V. and Zybin, K. P.: Runaway breakdown and the mysteries of lightning, Physics Today, 58, 37-43, 2005.

Güsten, H., Heinrich, G., Mönnich, E., Nolle, M., and Weppner, J.: Two automated ozone analysers for use on civil aircraft operating in the tropopause region, J. Atmos. Ocean. Technol., 20, 292300, 2003.

Haagen-Smit, A. J., Bradley, C. E., and Fox, M. M.: Ozone formation in photochemical oxidation of organic substances, Ind. Eng. Chem., 45, 2086-2089, 1953.

Hack, J. J.: Parametrization of moist convection in the National Center for Atmospheric Research community climate model (CCM2), J. Geophys. Res., 99, 5541-5568, doi:10.1029/93JD03478, 1994.

Hameed, S., Paidoussis, O. G., and Stewart, R. W.: Implications of natural sources for the latitudinal gradients of $\mathrm{NO}_{\mathrm{y}}$ in the unpolluted troposphere, Geophys. Res. Lett., 8, 591-594, 1981.

Hansen, J., Sato, M., Ruedy, R., et al.: Efficacy of climate forcings, J. Geophys. Res., 110, D18104, doi:10.1029/2005JD005776, 2005.

Harrison, H.: Atmospheric electric fields at the Kennedy Space Center, 1997-2005: No evidence for effects of global warming or modulation by galactic cosmic rays, Geophys. Res. Lett., 33, L10814, doi:10.1029/2006GL025880, 2006.

Harrison, R. G.: The global atmospheric electrical circuit and climate, Surv. Geophys., 25, 441-484, 2004.

Hastings, M. G., Sigman, D. M., and Lipschultz, F.: Isotopic evidence for source changes of nitrate in rain at Bermuda, J. Geophys. Res., 108, 4790, doi:10.1029/2003JD003789, 2003.

Hauf, T., Schulte, P., Alheit, R., and Schlager, H.: Rapid vertical trace gas transport by an isolated midlatitude thunderstorm, J. Geophys. Res., 100, 22 957-22 970, doi:10.1029/95JD02324, 1995.

Hauglustaine, D., Emmons, L., Newchurch, M., Brasseur, G., Takao, T., Matsubara, K., Johnson, J., Ridley, B., Stith, J., and Dye, J.: On the role of lightning $\mathrm{NO}_{\mathrm{x}}$ in the formation of tropospheric ozone plumes: a global model perspective, J. Atmos. Chem., 38, 277-294, 2001a.

Hauglustaine, D. A., Brasseur, G. P., Walters, S., Rasch, P. J., Mueller, J. F., Emmons, L. K., and Carroll, M. A.: MOZART, a global chemical transport model for ozone and related chemical tracers. Part 2: Model results and evaluation, J. Geophys. Res., 103, 28 291-28 335, 1998.

Hauglustaine, D. A., Brasseur, G. P., Hauglustaine, D. A., Brasseur, G. P., Walters, S., Rasch, P. J., Müller, J. F., Emmons, L. K., and Carroll, M. A.: Evolution of tropospheric ozone under anthropogenic activities and associated radiative forcing of climate, J. Geophys. Res., 106, 32 337-32360, doi:10.1029/2001JD900175, 2001b.

Hauglustaine, D. A., Hourdin, F., Jourdain, L., Filiberti, M. A., Walters, S., Lamarque, J. F., and Holland, E. A.: Interactive chemistry in the Laboratoire de Meteorologie Dynamique general circulation model: Description and background tropospheric chemistry evaluation, J. Geophys. Res., 109, 1-44, doi:10.1029/2003JD003957, 2004.

Hauglustaine, D. A., Lathiere, J., Szopa, S., and Folberth, G. A.: Future tropospheric ozone simulated with a climatechemistry-biosphere model, Geophys. Res. Lett., 32, 1-5,
doi:10.1029/2005GL024031, 2005.

Hegglin, M. I., Brunner, D., Peter, T., Hoor, P., Fischer, H., Staehelin, J., Krebsbach, M., Schiller, C., Parchatka, U., and Weers, U.: Measurements of $\mathrm{NO}, \mathrm{NO}_{\mathrm{y}}, \mathrm{N}_{2} \mathrm{O}$, and $\mathrm{O}_{3}$ during SPURT: implications for transport and chemistry in the lowermost stratosphere, Atmos. Chem. Phys., 6, 1331-1350, 2006, http://www.atmos-chem-phys.net/6/1331/2006/.

Hein, R., Dameris, M., Schnadt, C., et al.: Results of an interactively coupled atmospheric chemistry-general circulation model: comparison with observations, Ann. Geophys., 19, 435-457, 2001, http://www.ann-geophys.net/19/435/2001/.

Heirtzler, J. R.: The future of the South Atlantic anomaly and implications for radiation damage in space, J. Atmos. Solar-Terr. Phys., 64, 1701-1708, 2002.

Hendon, H. H. and Woddberry, K.: The diurnal cycle of tropical convection, J. Geophys. Res., 98, 16623-16 637, 1993.

Hild, L., Richter, A., Rozanov, V., and Burrows, J. P.: Air mass factor calculations for GOME measurements of lightning-produced $\mathrm{NO}_{2}$, Adv. Space Res., 29, 1685-1690, 2002.

Hill, R. D.: Energy dissipation in lightning, J. Geophys. Res., 82, 4967-4968, 1977.

Hill, R. D.: Survey of lightning energy estimates, Rev. Geophys. Space Phys., 17, 155-164, 1979.

Hill, R. D., Rinker, R. G., and Wilson, H. D.: Atmospheric nitrogen fixation by lightning, J. Atmos. Sci., 37, 179-192, 1980.

Hill, R. D., Rinker, R. G., and Coucouvinos, A.: Nitrous oxide production by lightning, J. Geophys. Res., 89, 1411-1421, 1984.

Hill, R. D., Rahmim, I., and Rinker, R. G.: Experimental study of the production of $\mathrm{NO}, \mathrm{N}_{2} \mathrm{O}$, and $\mathrm{O}_{3}$ in a simulated corona, Ind. Eng. Chem. Res., 27, 1264-1269, 1988.

Hiraki, Y., Tong, L., Fukunishi, H., Nanbu, K., Kasai, Y., and Ichimura, A.: Generation of metastable oxygen atom $\mathrm{O}(1 \mathrm{D})$ in sprite halos, Geophys. Res. Lett., 31, L14105, doi:10.1029/2004GL020048, 2004.

Hoell, J. M.: Pacific Exploratory Mission-Tropics A (PEM-Tropics A). Part 2, J. Geophys. Res., 104, 16 177-16 180, 1999.

Holland, D. M., Principe, P. P., and Sickles II, J. E.: Trends in atmospheric sulfur and nitrogen species in the eastern United States for 1989-1995, Atmos. Environ., 33, 37-49, 1999a.

Holland, E. A., Braswell, B. H., Lamarque, J.-F., et al.: Variations in the predicted spatial distribution of atmospheric nitrogen deposition and their impact on carbon uptake by terrestrial ecosystems, J. Geophys. Res., 102, 15 849-15 866, 1997.

Holland, E. A., Dentener, F. J., Braswell, B. H., and Sulzman, J. M.: Contemporary and pre-industrial global reactive nitrogen budgets, Biogechemistry, 46, 7-43, $1999 \mathrm{~b}$.

Höller, H., Finke, U., Huntrieser, H., Hagen, M., and Feigl, C.: Lightning-produced $\mathrm{NO}_{\mathrm{x}}$ (LINOX): experimental design and case study results, J. Geophys. Res., 104, 13911-13922, doi:10.1029/1999JD900019, 1999.

Höller, H., Fehr, T., Thery, C., Seltmann, J., and Huntrieser, H.: Radar, lightning, airborne observations and modelling of a supercell storm during EULINOX, Phys. Chem. Earth, B25, 12811284, 2000.

Höller, H. and Schumann, U.: EULINOX - The European Lightning Nitrogen Oxides Project, 240 pp, Deutsches Zentrum für Luft- und Raumfahrt, Köln, Germany, DLR-FB 2000-28, 2000.

Holmes, C., Brook, M., Krebiel, P., and McRory, R.: On the power 
spectrum and mechanism of thunder, J. Geophys. Res., 76, 2106$2115,1971$.

Hopkins, A. E.: Lightning $\mathrm{NO}_{\mathrm{x}}$ and tropospheric ozone formation in the NASA GISS global carbon model, GSSP (Graduate Student Summer Program of the NASA Goddard Space Flight Center's Earth-Sun Exploration Division, in collaboration with the Goddard Earth Sciences and Technology Center of the University of Maryland Baltimore County), http://gest.umbc.edu/ student_opp/2003_gssp_reports.html, 2003.

Horowitz, L. W. and Jacob, D. J.: Global impact of fossil fuel combustion on atmospheric $\mathrm{NO}_{\mathrm{x}}$, J. Geophys. Res., 104, $23823-$ $23840,1999$.

Horowitz, L. W., Walters, S., Mauzerall, D. L., et al.: A global simulation of tropospheric ozone and related tracers: Description and evaluation of MOZART, version 2, J. Geophys. Res., 108, 4784, doi:10.1029/2002JD002853, 2003.

Houze, R. A.: Mesoscale convective systems, Rev. Geophys., 42, RG4003, doi:10.1029/2004RG000150, 2004.

Howard, J. B. and Rees, D. C.: Structural basis of biological nitrogen fixation, Chem. Rev., 96, 2965-2982, 1996.

Hübler, G., Fahey, D. W., Ridley, B. A., Gregory, G. L., and Fehsenfeld, F. C.: Airborne measurements of total reactive odd nitrogen $\left(\mathrm{NO}_{\mathrm{y}}\right)$, J. Geophys. Res., 97, 9833-9850, 1992.

Hudman, R. C., Jacob, D. J., Cooper, O. R., et al.: Ozone production in transpacific Asian pollution plumes and implications for ozone air quality in California, J. Geophys. Res., 109, 1-14, doi:10.1029/2004JD004974, 2004.

Hudman, R. C., Jacob, D. J., Turquety, S., et al.: Surface and lightning sources of nitrogen oxides over the United States: Magnitudes, chemical evolution, and outflow, J. Geophys. Res., 112, D12S05, doi:10.1029/2006JD007912, 2007.

Huntrieser, H., Schlager, H., van Velthoven, P., Schulte, P., Ziereis, H., Schumann, U., Arnold, F., and Ovarlez, J.: In-situ trace gas observations in dissipating thunderclouds during POLINAT, paper presented at 12th International Conference on Clouds and Precipitation, Zürich, Am. Meteor. Soc., Boston, Mass., 1996.

Huntrieser, H., Schlager, H., Feigl, C., and Höller, H.: Transport and production of $\mathrm{NO}_{\mathrm{x}}$ in electrified thunderstorms: Survey of previous studies and new observations at midlatitudes, J. Geophys. Res., 103, 28 247-28 264, doi:10.1029/98JD02353, 1998.

Huntrieser, H., Feigl, C., Schlager, H., et al.: Airborne measurements of $\mathrm{NO}_{\mathrm{x}}$, tracer species, and small particles during the European Lightning Nitrogen Oxides Experiment, J. Geophys. Res., 107, 4113, doi:10.1029/2000JD000209, 2002.

Huntrieser, H., Heland, J., Schlager, H., et al.: Intercontinental air pollution transport from North America to Europe: Experimental evidence from airborne measurements and surface observations J. Geophys. Res., 110, D01305, doi:10.1029/2004JD005045, 2005.

Huntrieser, H., Schlager, H., Höller, H., Schumann, U., Betz, H. D., Boccippio, D., Brunner, D., Forster, C., and Stohl, A.: Lightningproduced $\mathrm{NO}_{\mathrm{x}}$ in tropical, subtropical and midlatitude thunderstorms: New insights from airborne and lightning observations, Geophys. Res. Abstr., 8, 03286, 2006.

Huntrieser, H., Schlager, H., Roiger, A., Lichtenstern, M., Schumann, U., Kurz, C., Brunner, D., Schwierz, C., Richter, A., and Stohl, A.: Lightning-produced $\mathrm{NO}_{\mathrm{x}}$ over Brazil during TROCCINOX: airborne measurements in tropical and subtropical thunderstorms and the importance of mesoscale convective systems,
Atmos. Chem. Phys., 7, 2987-3013, 2007, http://www.atmos-chem-phys.net/7/2987/2007/.

Hutchinson, G. E.: The biochemistry of the terrestrial atmosphere, in: The Earth as a Planet, edited by: Kuiper, G. P., Univ. Chicago Press, Chicago, 1954.

Ignaccolo, M., Farges, T., Mika, A., Allin, T. H., Chanrion, O., Blanc, E., Neubert, T., Fraser-Smith, A. C., and Füllekrug, M.: The planetary rate of sprite events, Geophys. Res. Lett., 33, L11808, doi:10.1029/2005GL025502, 2006.

IPCC: Climate Change 1992, The Supplementary Report to the IPCC Scientific Assessment, 200 pp., Cambridge Univ. Press, New York, 1992.

IPCC: Aviation and the Global Atmosphere, 373 pp., Cambridge Univ. Press, Cambridge, UK, 1999.

IPCC: Climate change 2001: The Scientific Basis, 881 pp., Cambridge University Press, Cambridge, UK, New York, 2001.

Irie, H., Sudo, K., Akimoto, H., et al.: Evaluation of long-term tropospheric $\mathrm{NO}_{2}$ data obtained by GOME over East Asia in 1996-2002, Geophys. Res. Lett., 32, 1-4, doi:10.1029/2005GL022770, 2005.

Isaksen, I. S. A. and Hov, Ø.: Calculation of trends in the tropospheric concentration of $\mathrm{O}_{3}, \mathrm{OH}, \mathrm{CO}, \mathrm{CH}_{4}$, and $\mathrm{NO}_{\mathrm{x}}$, Tellus, 39B, 271-285, 1987.

Isaksen, I. S. A.: Is the oxidizing capacity of the atmosphere changing?, in: The Changing Atmosphere, edited by: Rowland, F. S. and Isaksen, I. S. A., pp. 141-157, John Wiley \& Sons, Chichester, 1988.

Jacob, D. J., Heikes, B. G., Fan, S.-M., et al.: Origin of ozone and $\mathrm{NO}_{\mathrm{x}}$ in the tropical troposphere: A photochemical analysis of aircraft observations over the South Atlantic basin, J. Geophys. Res., 101, 24 235-24 250, doi:10.1029/1996JD00336, 1996.

Jacobson, A. R., Holzworth, R., Harlin, J., Dowden, R., and Lay, E.: Performance assessment of the World Wide Lightning Location Network (WWLLN), using the Los Alamos Sferic Array (LASA) as ground truth, J. Atmos. Ocean. Technol., 23, 10821092, doi:10.1175/JTECH1902.1, 2006.

Jadhav, D. B., Londhe, A. L., and Bose, S.: Observations of $\mathrm{NO}_{2}$ and $\mathrm{O}_{3}$ during thunderstorm activity using visible spectroscopy, Adv. Atmos. Sci., 13, 359-374, 1996.

Jaeglé, L., Jacob, D. J., Wennberg, P. O., et al.: Observed OH and $\mathrm{HO}_{2}$ in the upper troposphere suggest a major source from convective injection of peroxides, Geophys. Res. Lett., 24, 31813184, 1997.

Jaeglé, L., Jacob, D. J., Wang, Y., Weinheimer, A. J., Ridley, B. A., Campos, T. L., Sachse, G. W., and Hagen, D. E.: Sources and chemistry of $\mathrm{NO}_{\mathrm{x}}$ in the upper troposphere over the United States, Geophys. Res. Lett., 25, 1705-1708, doi:10.1029/97GL03591, 1998.

Jaeglé, L., Jacob, D. J., Brune, W. H., et al.: Ozone production in the upper troposphere and the influence of aircraft during SONEX: Approach of $\mathrm{NO}_{\mathrm{X}}$-saturated conditions, Geophys. Res. Lett., 26, 3081-3084, 1999.

Jaeglé, L., Jacob, D. J., Brune, W. H., and Wennberg, P. O.: Chemistry of $\mathrm{HO}_{\mathrm{x}}$ radicals in the upper troposphere, Atmos. Environ., 35, 469-489, 2001.

Jaeglé, L., Martin, R. V., Chance, K., Steinberger, L., Kurosu, T. P., Jacob, D. J., Modi, A. I., Yoboue, V., Sigha-Nkamdjou, L., and Galy-Lacaux, C.: Satellite mapping of rain-induced nitric oxide emissions from soils, J. Geophys. Res., 109, D21310, 
doi:10.1029/2004JD004787, 2004.

Jaeglé, L., Steinberger, L., Martin, R. V., and Chance, K.: Global partitioning of $\mathrm{NO}_{\mathrm{x}}$ sources using satellite observations: Relative roles of fossil fuel combustion, biomass burning and soil emissions, Faraday Discuss., 130, 407-423, 2005.

Jaffe, D. A., Berntsen, T. K., and Isaksen, I. S. A.: A global threedimensional chemical transport model. Part 2: Nitrogen oxides and nonmethane hydrocarbon results, J. Geophys. Res., 102, 21 281-21 296, 1997.

Jayakumar, V., Rakov, V. A., Miki, M., Uman, M. A., Schnetzer, G. H., and Rambo, K. J.: Estimation of input energy in rocket-triggered lightning, Geophys. Res. Lett., 33, L05702, doi:10.1029/2005GL025141, 2006.

Jayaratne, E. R. and Kuleshov, Y.: Geographical and seasonal characteristics of the relationship between lightning ground flash density and rainfall within the continent of Australia, Atmos. Res., 79, 1-14, 2006.

Jeker, D. P., Pfister, L., Thompson, A. M., Brunner, D., Boccippio, D. J., Pickering, K. E., Wernli, H., Kondo, Y., and Staehelin, J.: Measurements of nitrogen oxides at the tropopause: Attribution to convection and correlation with lightning, J. Geophys. Res., 105, 3679-3700, doi:10.1029/1999JD901053, 2000.

Jenkins, G. S., Ryu, J. H., Thompson, A. M., and Witte, J. C.: Linking horizontal and vertical transports of biomass fire emissions to the Tropical Atlantic Ozone Paradox during the Northern Hemisphere winter season: 1999, J. Geophys. Res., 108, 4745, doi:10.1029/2002JD003297, 2003.

Jerauld, J., Rakov, V. A., Uman, M. A., Rambo, K. J., Jordan, D. M., Cummins, K. L., and Cramer, J. A.: An evaluation of the performance characteristics of the U.S. National Lightning Detection Network in Florida using rocket-triggered lightning, J. Geophys. Res., 110, D19106, doi:10.1029/2005JD005924, 2005.

Jeuken, A. B. M., Siegmund, P. C., Heijboer, L. C., Feichter, J., and Bengtsson, L.: On the potential of assimilating meteorological analyses in a global climate model for the purpose of model validation, J. Geophys. Res., 101, 16939-16950, 1996.

Jöckel, P., Tost, H., Pozzer, A., et al.: The atmospheric chemistry general circulation model ECHAM5/MESSy1: consistent simulation of ozone from the surface to the mesosphere, Atmos. Chem. Phys., 6, 5067-5104, 2006,

http://www.atmos-chem-phys.net/6/5067/2006/.

Johnson, C. E., Henshaw, J., and Mclnnes, G.: Impact of aircraft and surface emissions of nitrogen oxides on tropospheric ozone and global warming, Nature, 355, 69-71, doi:10.1038/355069a0, 1992.

Johnson, R. H. and Mapes, B. E.: Mesoscale processes and severe convective weather, in: Severe Convective Storms, Meteorol. Monographs, Vol. 28, No. 50, edited by: Doswell III, C. A., pp. 71-122, Amer. Met. Soc., Boston, Mass, 2001.

Johnston, H. S.: Reduction of stratospheric ozone by nitrogen oxide, catalysts from supersonic transport exhaust, Science, 173, 517-522, 1971.

Jonquieres, I. and Marenco, A.: Redistribution by deep convection and long-range transport of $\mathrm{CO}$ and $\mathrm{CH}_{4}$ emissions from the Amazon basin, as observed by the airborne campaign TROPOZ II during the wet season J. Geophys. Res., 103, 19075-19091, 1998.

Jorgenson, D. P. and LeMone, M. A.: Vertical velocity characteristics of oceanic convection, J. Atmos. Sci., 46, 621-640, 1989.
Jourdain, L. and Hauglustaine, D. A.: The global distribution of lightning $\mathrm{NO}_{\mathrm{x}}$ simulated on-line in a general circulation model, Phys. Chem. Earth, C26, 585-591, 2001.

Kasibhatla, P. S., Levy II, H., and Moxim, W. J.: Global $\mathrm{NO}_{\mathrm{x}}$, $\mathrm{HNO}_{3}, \mathrm{PAN}$, and $\mathrm{NO}_{\mathrm{y}}$ distributions from fossil fuel combustion emissions: a model study, J. Geophys. Res., 98, 7165-7180, 1993.

Kawakami, S., Kondo, Y., Koike, M., et al.: Impact of lightning and convection on reactive nitrogen in the tropical free troposphere, J. Geophys. Res., 102, 28 367-28 384, doi:10.1029/97JD02073, 1997.

Khaerdinov, N. S., Lidvansky, A. S., and Petkov, V. B.: Cosmic rays and the electric field of thunderclouds: Evidence for acceleration of particles (runaway electrons), Atmos. Res., 76, 346-354, 2005.

Kita, K., Kawakami, S., Miyazaki, Y., et al.: Photochemical production of ozone in the upper troposphere in association with cumulus convection over Indonesia, J. Geophys. Res., 108, 8400, doi:10.1029/2001JD000844, 2003.

Kley, D., Drummond, J. W., McFarland, M., and Liu, S. C.: Tropospheric profiles of $\mathrm{NO}_{\mathrm{x}}$, J. Geophys. Res., 86, 3153-3161, 1981.

Ko, M., Hu, W., Rodriguez, J. M., Kondo, Y., Koike, M., Kita, K., Kawakami, S., Blake, D., Liu, S., and Ogawa, T.: Photochemical ozone budget during the BIBLE A and B campaigns, J. Geophys. Res., 108, 8404, doi:10.1029/2001JD000800, 2003.

Ko, M. K. W.: Lightning: a possible source of stratospheric odd nitrogen, J. Geophys. Res., 91, 5395-5404, 1986.

Köhler, I., Sausen, R., and Reinberger, R.: Contributions of aircraft emissions to the atmospheric $\mathrm{NO}_{\mathrm{x}}$ content, Atmos. Environ., 31, 1801-1818, 1997.

Koike, M., Kondo, Y., Ikeda, H., et al.: Impact of aircraft emissions on reactive nitrogen over the North Atlantic Flight Corridor region, J. Geophys. Res., 105, 3665-3677, 2000.

Koike, M., Kondo, Y., Kita, K., et al.: Reactive nitrogen over the tropical western Pacific: Influence from lightning and biomass burning during BIBLE A, J. Geophys. Res., 108, 8403, doi:10.1029/2001JD000823, 2003.

Koike, M., Kondo, Y., Kita, K., et al.: Measurements of reactive nitrogen produced by tropical thunderstorms during BIBLE-C, J. Geophys. Res., in press, doi:10.1029/2006JD008193, 2007.

Kondo, Y., Ko, M., Koike, M., Kawakami, S., and Ogawa, T.: Preface to Special Section on Biomass Burning and Lightning Experiment (BIBLE), J. Geophys. Res., 108, 8397, doi:10.1029/2002JD002401, 2003a.

Kondo, Y., Koike, M., Kita, K., et al.: Effects of biomass burning, lightning, and convection on $\mathrm{O}_{3}, \mathrm{CO}$, and $\mathrm{NO}_{\mathrm{y}}$ over the tropical Pacific and Australia in August-October 1998 and 1999, J. Geophys. Res., 108, 8402, doi:10.1029/2001JD000820, 2003b.

Konovalov, I. B., Beekmann, M., Vautard, R., Burrows, J. P., Richter, A., Nuess, H., and Elansky, N.: Comparison and evaluation of modelled and GOME measurement derived tropospheric $\mathrm{NO}_{2}$ columns over Western and Eastern Europe, Atmos. Chem. Phys., 5, 169-190, 2005,

http://www.atmos-chem-phys.net/5/169/2005/.

Kotaki, M. and Katoh, C.: The global distribution of thunderstorms activity observed by the Ionosphere Sounding Satellite (ISS-b), J. Atmos. Terr. Phys., 45, 833-847, 1983.

Kotamarthi, V. R., Ko, M. K. W., Weisenstein, D. K., Rodriguez, J. M., and Sze, N. D.: Effect of lightning on the concentration 
of odd nitrogen species in the lower stratosphere: An update, J. Geophys. Res., 99, 8167-8173, doi:10.1029/93JD03477, 1994.

Kowalczyk, M. and Bauer, E.: Lightning as a source of $\mathrm{NO}_{\mathrm{x}}$ in the troposphere, Tech. Rep. FAA-EE-82-4, 76 pp., Inst. for Def. Anal., Alexandria, Virginia, 1981.

Kraabøl, A. G., Flat $\varnothing y$, F., and Stordal, F.: Impact of $\mathrm{NO}_{\mathrm{x}}$ emissions from subsonic aircraft: Inclusion of plume processes in a three-dimensional model covering Europe, North America, and the North Atlantic, J. Geophys. Res., 105, 3573-3581, 2000.

Kraus, A. B., Rohrer, F., Grobler, E. S., and Ehhalt, D. H.: The global tropospheric distribution of $\mathrm{NO}_{\mathrm{x}}$ estimated by a three-dimensional chemical tracer model, J. Geophys. Res., 101, 18 587-18 604, doi:10.1029/96JD01546, 1996.

Krehbiel, P. R., Thomas, R. J., Hamlin, T., Harlin, J., and Davis, M.: GPS-based mapping system reveals lightning inside storms, EOS, 81, 21-25, 2000.

Krider, E. P., Dawson, G. A., and Uman, M. A.: The peak power and energy dissipation in a single-stroke lightning flash, J. Geophys. Res., 73, 3335-3339, 1968.

Kroening, J. L. and Ney, E. P.: Atmospheric ozone, J. Geophys. Res., 67, 1867-1875, 1962.

Kuhlman, K. M., Ziegler, C. L., Mansell, E. R., MacGorman, D. R., and Straka, J. M.: Numerically simulated electrification and lightning of the 29 June 2000 STEPS supercell storm, Mon. Wea. Rev., 134, 2734-2757, 2006.

Kuleshov, Y., Mackerras, D., and Darveniza, M.: Spatial distribution and frequency of lightning activity and lightning flash density maps for Australia, J. Geophys. Res., 111, D19105, doi:10.1029/2005JD006982, 2006.

Kulmala, M., Reissell, A., Sipilä, M., Bonn, B., Ruuskanen, T. M., Lehtinen, K. E. J., Kerminen, V.-M., and Ström, J.: Deep convective clouds as aerosol production engines: Role of insoluble organics, J. Geophys. Res., 111, D17202, doi:10.1029/2005JD006963, 2006.

Kulshrestha, U. C., Granat, L., Engardt, M., and Rodhe, H.: Review of precipitation monitoring studies in India - a search for regional patterns, Atmos. Environ., 39, 7403-7419, 2005.

Kumar, P. P., Manohar, G. K., and Kandalgaonkar, S. S.: Global distribution of nitric oxide produced by lightning and its seasonal variation, J. Geophys. Res., 100, 11 203-11 208, 1995.

Kunhikrishnan, T., Lawrence, M. G., Von Kuhlmann, R., Richter, A., Ladstätter-Weißenmayer, A., and Burrows, J. P.: Analysis of tropospheric $\mathrm{NO}_{\mathrm{x}}$ over Asia using the model of atmospheric transport and chemistry (MATCH-MPIC) and GOME-satellite observations, Atmos. Environ., 38, 581-596, 2004.

Kurz, C. and Grewe, V.: Lightning and thunderstorms, Part I: Observational data and model results, Meteorol. Z., 11, 379-393, 2002.

Kurz, C.: Entwicklung und Anwendung eines gekoppelten Klima-Chemie-Modellsystems, 142 pp, Doctoral Dissertation, http://edoc.ub.uni-muenchen.de/archive/00004804/01/ Kurz_Christian.pdf, Ludwig-Maximilians-Universität München, 2006.

Labrador, L. J., Kuhlmann, R. v., and Lawrence, M. G.: Strong sensitivity of the global mean $\mathrm{OH}$ concentration and the tropospheric oxidizing efficiency to the source of $\mathrm{NO}_{\mathrm{x}}$ from lightning, Geophys. Res. Lett., 31, 1-4, doi:10.1029/2003GL019229, 2004.

Labrador, L. J., von Kuhlmann, R., and Lawrence, M. G.: The effects of lightning-produced $\mathrm{NO}_{\mathrm{x}}$ and its vertical distribution on atmospheric chemistry: sensitivity simulations with MATCHMPIC, Atmos. Chem. Phys., 5, 1815-1834, 2005, http://www.atmos-chem-phys.net/5/1815/2005/.

Lacis, A. A., Wuebbles, D. J., and Logan, J. A.: Radiative forcing of climate by changes in the vertical distribution of ozone, J. Geophys. Res., 95, 9971-9981, 1990.

Laing, A. G. and Fritsch, J. M.: The global population of mesoscale convective complexes, Quart. J. Roy. Meteor. Soc., 123, 389405, 1997.

Lamarque, J. F., Brasseur, G. P., Hess, P. G., and Mueller, J. F.: Three-dimensional study of the relative contributions of the different nitrogen sources in the troposphere, J. Geophys. Res., 101, 22 955-22 968, 1996.

Lamarque, J. F., Hess, P. G., and Tie, X. X.: Three-dimensional model study of the influence of stratosphere-troposphere exchange and its influence on tropospheric chemistry, J. Geophys. Res., 104, 26363-26372, 1999.

Lamarque, J. F., Kiehl, J. T., Brasseur, G. P., et al.: Assessing future nitrogen deposition and carbon cycle feedback using a multimodel approach: Analysis of nitrogen deposition, J. Geophys. Res., 110, 1-21, doi:10.1029/2005JD005825, 2005.

Lang, T. J. and Rutledge, S. A.: Relationship between convective storm kinetics, precipitation, and lightning, Mon. Wea. Rev., 130, 2492-2506, 2002.

Lang, T. J., Miller, L. J., Weisman, M., et al.: The Severe Thunderstorm Electrification and Precipitation Study, Bull. AMS, 85, 1107-1125, 2004.

Lang, T. J. and Rutledge, S. A.: Cloud-to-ground lightning downwind of the 2002 Hayman forest fire in Colorado, Geophys. Res. Lett., 33, L03804, doi:10.1029/2005GL024608, 2006.

Lange, L., Hoor, P., Helas, G., et al.: Detection of lightningproduced NO in the midlatitude upper troposphere during STREAM 1998, J. Geophys. Res., 106, 27 777-27 785, doi:10.1029/2001JD900210, 2001.

Langford, A. O., Portmann, R. W., Daniel, J. S., Miller, H. L., and Solomon, S.: Spectroscopic measurements of $\mathrm{NO}_{2}$ in a Colorado thunderstorm: Determination of the mean production by cloudto-ground lightning flashes, J. Geophys. Res., 109, D11304, doi:10.1029/2003JD004158, 2004.

Lauer, A., Dameris, M., Richter, A., and Burrows, J. P.: Tropospheric $\mathrm{NO}_{2}$ columns: a comparison between model and retrieved data from GOME measurements, Atmos. Chem. Phys., 2, 67-78, 2002, http://www.atmos-chem-phys.net/2/67/2002/.

Law, K., Pan, L., Wernli, H., Fischer, H., Haynes, P. H., Salawitch, R., Kärcher, B., Prather, M., Doherty, S., and Ravishankara, A. R.: Processes governing the chemical composition of the extratropical UTLS - A report from the joint SPARC-IGAC Workshop, SPARC Newsletter, 26, 8-19, 2006.

Law, K. S. and Pyle, J. A.: Modeling trace gas budgets in the troposphere. 1. Ozone and odd nitrogen, J. Geophys. Res., 98, $18377-$ $18400,1993$.

Law, K. S., Plantevin, P. H., Shallcross, D. E., Rogers, H. L., Pyle, J. A., Grouhel, C., Thouret, V., and Marenco, A.: Evaluation of modeled $\mathrm{O}_{3}$ using Measurement of Ozone by Airbus In-Service Aircraft (MOZAIC) data J. Geophys. Res., 103, 25 721-25 737, 1998.

Lawrence, M. G., Chameides, W. L., Kasibhatla, P. S., Levy II, H., and Moxim, W.: Lightning and atmospheric chemistry: The rate 
of atmospheric NO production, in: Handbook of Atmospheric Electrodynamics, edited by: Volland, H., pp. 189-202, CRC Press, Boca Raton, Florida, 1995.

Lawrence, M. G., Crutzen, P. J., Rasch, P. J., Eaton, B. E., and Mahowald, N. M.: A model for studies of tropospheric photochemistry: Description, global distributions, and evaluation, J. Geophys. Res., 104, 26 245-26278, doi:10.1029/1999JD900425, 1999.

Lawrence, M. G., Rasch, P. J., von Kuhlmann, R., et al.: Global chemical weather forecasts for field campaign planning: predictions and observations of large-scale features during MINOS, CONTRACE, and INDOEX, Atmos. Chem. Phys., 3, 267-289, 2003a.

Lawrence, M. G., von Kuhlmann, R., Salzmann, M., and Rasch, P. J.: The balance of effects of deep convective mixing on tropospheric ozone, Geophys. Res. Lett., 30, 1940, doi:10.1029/2003GL017644, 2003b.

Lay, E. H., Holzworth, R. H., Rodger, C. J., Thomas, J. N., Pinto Jr., O., and Dowden, R. L.: WWLL global lightning detection system: Regional validation study in Brazil, Geophys. Res. Lett., 31, L03102, doi:10.1029/2003GL018882, 2004.

Lee, D. S., Kohler, I., Grobler, E., Rohrer, F., Sausen, R., GallardoKlenner, L., Olivier, J. G. J., Dentener, F. J., and Bouwman, A. F.: Estimations of global $\mathrm{NO}_{\mathrm{x}}$ emissions and their uncertainties, Atmos. Environ., 31, 1735-1749, 1997.

Leeuwen, E. P. V., Draaijers, G. P. J., and Erisman, J. W.: Mapping wet deposition of acidifying components and base cations over Europe using measurements, Atmos. Environ., 30, 2495-2511, 1996.

Legrand, M. R. and Kirchner, S.: Origins and variations of nitrate in south polar precipitation, J. Geophys. Res., 95, 3493-3507, doi:10.1029/89JD01223, 1990.

Lelieveld, J. and Crutzen, P. J.: Role of deep cloud convection in the ozone budget of the troposphere, Science, 264, 1759-1761, 1994.

Lelieveld, J., Crutzen, P. J., and Dentener, F. J.: Changing concentration, lifetime and climate forcing of atmospheric methane, Tellus, 50B, 128-150, 1998.

Lelieveld, J. and Dentener, F. J.: What controls tropospheric ozone?, J. Geophys. Res., 105, 3531-3551, 2000.

Lelieveld, J., Dentener, F. J., Peters, W., and Krol, M. C.: On the role of hydroxyl radicals in the self-cleansing capacity of the troposphere, Atmos. Chem. Phys., 4, 2337-2344, 2004, http://www.atmos-chem-phys.net/4/2337/2004/.

Leue, C., Wenig, M., Wagner, T., Klimm, O., Platt, U., and Jähne, B.: Quantitative analysis of $\mathrm{NO}_{2}$ emissions from Global Ozone Monitoring Experiment satellite image sequences, J. Geophys. Res., 106, 5493-5505, 2001.

Levelt, P. F., van den Oord, G. H. J., Dobber, M. R., Malkki, A., Visser, H., de Vries, J., Stammes, P., Lundell, J. O. V., and Saari, H.: The Ozone Monitoring Instrument, IEEE Trans. Geo. Rem. Sens., 44, 1093-1101, 2006.

Levine, J. S., Hughes, R. E., Chameides, W. L., and Howell, W. E.: $\mathrm{N}_{2} \mathrm{O}$ and $\mathrm{CO}$ production by electrical discharge: Atmospheric implications, Geophys. Res. Lett., 6, 557-559, 1979.

Levine, J. S.: Simultaneous measurements of $\mathrm{NO}_{\mathrm{x}}, \mathrm{NO}$, and $\mathrm{O}_{3}$ production in a laboratory discharge: atmospheric implications, Geophys. Res. Lett., 8, 357-360, 1981.

Levine, J. S. and Shaw Jr., E. F.: In situ aircraft measurements of enhanced levels of $\mathrm{N}_{2} \mathrm{O}$ associated with thunderstorm lightning, Nature, 303, 312-314, 1983.

Levy II, H.: Normal atmosphere: Large radical and formaldehyde concentrations predicted, Science, 173, 141-143, 1971.

Levy II, H., Moxim, W. J., and Kasibhatla, P. S.: A global threedimensional time-dependent lightning source of tropospheric $\mathrm{NO}_{\mathrm{x}}$, J. Geophys. Res., 101, 22 911-22 922, 1996.

Levy II, H., Moxim, W. J., Klonecki, A. A., and Kasibhatla, P. S.: Simulated tropospheric $\mathrm{NO}_{\mathrm{x}}$ : its evaluation, global distribution and individual source contributions, J. Geophys. Res., 104, 26 279-26306, 1999.

Lhermitte, R. and Krehbiel, P. R.: Doppler radar and radio observations of thunderstorms, IEEE Trans. Geosci. Electron., GE-17, 162-171, 1979.

Li, Q., Jacob, D. J., Logan, J. A., et al.: A tropospheric ozone maximum over the Middle East, Geophys. Res. Lett., 28, 3235-3238, 2001.

Liaw, Y. P., Sisterson, D. L., and Miller, N. L.: Comparison of field, laboratory, and theoretical estimates of global nitrogen fixation by lightning, J. Geophys. Res., 95, 22 489-22 494, doi:10.1029/90JD02023, 1990.

Liu, S. C.: Possible effects on tropospheric $\mathrm{O}_{3}$ and $\mathrm{OH}$ due to NO emissions, Geophys. Res. Lett., 4, 325-328, 1977.

Llewellyn, E. J., Lloyd, N. D., Degenstein, D. A., et al.: The OSIRIS instrument on the Odin satellite, Can. J. Phys., 82, 411422, 2004.

Logan, J. A., Prather, M. J., Wofsy, S. C., and McElroy, M. B.: Tropospheric chemistry: A global perspective, J. Geophys. Res., 86, 7210-7254, 1981.

Logan, J. A.: Nitrogen oxides in the troposphere: global and regional budgets, J. Geophys. Res., 88, 10 785-10 807, 1983.

Lucas, C., Zipser, E. J., and LeMone, M. A.: Convective available potential energy in the environment of oceanic and continental clouds: Correction and comments, J. Atmos. Sci., 51, 39293830, 1994a.

Lucas, C., Zipser, E. J., and LeMone, M. A.: Vertical velocity in oceanic convection off tropical Australia, J. Atmos. Sci., 51, 3183-3193, 1994b.

Luke, W. T., Dickerson, R. R., Ryan, W. F., Pickering, K. E., and Nunnermacker, L. J.: Tropospheric chemistry over the lower Great Plains of the United States. 2. Trace gas profiles and distributions, J. Geophys. Res., 97, $20647-20670$, doi:10.1029/92JD02127, 1992.

Lyons, W. A., Nelson, T. E., Williams, E. R., Cramer, J. A., and Turner, T. R.: Enhanced positive cloud-to-ground lightning in thunderstorms ingesting smoke from fires, Science, 282, 77-80, 1998a.

Lyons, W. A., Uliasz, M., and Nelson, T. E.: Large peak current cloud-to-ground lightning flashes during the summer months in the contiguous United States, Mon. Wea. Rev., 126, 2217-2233, 1998 b.

Ma, J., Richter, A., Burrows, J. P., Nüß, H., and von Ardenne, J. A.: Comparison of model-simulated tropospheric $\mathrm{NO}_{2}$ over China with GOME-satellite data, Atmos. Environ., 40, 593-604, 2006.

Ma, M., Tao, S., Zhu, B., Lue, W., and Tan, Y.: Response of global lightning activity to air temperature variation, Chin. Sci. Bull., 50, 2640-2644, 2005.

MacGorman, D. R. and Rust, W. D.: The Electrical Nature of Storms, 422 pp., Oxford Univ. Press, Oxford, 1998. 
MacGorman, D. R., Filiaggi, T., Holle, R. L., and Brown, R. A.: Negative cloud-to-ground lightning flash rates relative to VIL, maximum reflectivity, cell height, and cell isolation, J. Lightning Res., 1, 132-147, http://www.jolr.org, 2007.

Mach, D. M., Christian, H. J., Blakeslee, R. J., Boccippio, D. J., Goodman, S. J., and Boeck, W. L.: Performance assessment of the Optical Transient Detector and Lightning Imaging Sensor, J. Geophys. Res., 112, D09210, doi:10.1029/2006JD007787, 2007.

Mackerras, D. and Darveniza, M.: Latitudinal variation of lightning occurrence characteristics, J. Geophys. Res., 99, 10 813-10 821, 1994.

Mackerras, D., Darveniza, M., Orville, R. E., Williams, E. R., and Goodman, S. J.: Global lightning: Total, cloud and ground flash estimates, J. Geophys. Res., 103, 19791-19809, 1998.

Maddox, R. A.: An objective technique for separating macroscale and mesoscale features in meteorological data, Mon. Wea. Rev., 108, 1108-1121, 1980.

Manabe, S., Smagorinsky, J., and Strickler, R. G.: Simulated climatology of a general circulation model with a hydrological cycle, Mon. Wea. Rev., 93, 769-798, 1965.

Mansell, E. R., Ziegler, C. L., and Macgorman, D. R.: A lightning data assimilation technique for mesoscale forecast models, Mon. Wea. Rev., 135, 1732-1748, doi:10.1175/MWR3387.1, 2007.

Marécal, V., Rivière, E. D., Held, G., Cautenet, S., and Freitas, S.: Modelling study of the impact of deep convection on the UTLS air composition - Part I: Analysis of ozone precursors, Atmos. Chem. Phys., 6, 1567-1584, 2006, http://www.atmos-chem-phys.net/6/1567/2006/.

Marenco, A., Thouret, V., Nedelec, P., et al.: Measurement of ozone and water vapor by Airbus in-service aircraft: the MOZAIC airborne program, an overview, J. Geophys. Res., 103, 25631$25642,1998$.

Mari, C., Chaboureau, J. P., Pinty, J. P., et al.: Regional lightning $\mathrm{NO}_{\mathrm{x}}$ sources during the TROCCINOX experiment, Atmos. Chem. Phys., 6, 5559-5572, 2006,

http://www.atmos-chem-phys.net/6/5559/2006/.

Marshall, T. C., McCarthy, M. P., and Rust, W.: Electric field magnitudes and lightning initiation in thunderstorms, J. Geophys. Res., 100, 7097-7103, 1995.

Martin, R. V., Jacob, D. J., Logan, J. A., Ziemke, J. M., and Washington, R.: Detection of a lightning influence on tropical tropospheric ozone, Geophys. Res. Lett., 27, 1639-1642, 2000.

Martin, R. V., Chance, K., Jacob, D. J., et al.: An improved retrieval of tropospheric nitrogen dioxide from GOME, J. Geophys. Res., 107, 4437, doi:10.1029/2001JD001027, 2002a.

Martin, R. V., Jacob, D. J., Logan, J. A., Bey, I., Yantosca, R. M., Staudt, A. C., Li, Q., Fiore, A. M., Duncan, B. N., and Liu, H.: Interpretation of TOMS observations of tropical tropospheric ozone with a global model and in situ observations, J. Geophys. Res., 107, 4351, doi:10.1029/2001JD001480, 2002 b.

Martin, R. V., Jacob, D. J., Chance, K., Kurosu, T. P., Palmer, P. I., and Evans, M. J.: Global inventory of nitrogen oxide emissions constrained by space-based observations of $\mathrm{NO}_{2}$ columns, J. Geophys. Res., 108, 4537, doi:10.1029/2003JD003453, 2003.

Martin, R. V., Sioris, C. E., Chance, K., Ryerson, T. B., Bertram, T. H., Wooldridge, P. J., Cohen, R. C., Neuman, J. A., Swanson, A., and Flocke, F. M.: Evaluation of space-based constraints on global nitrogen oxide emissions with regional aircraft measurements over and downwind of eastern North America, J. Geophys.
Res., 111, D15308, doi:10.1029/2005JD006680, 2006.

Martin, R. V., Sauvage, B., Folkins, I., Sioris, C. E., Boone, C., Bernath, P., and Ziemke, J.: Space-based constraints on the production of nitric oxide by lightning, J. Geophys. Res., 112, D09309, doi:10.1029/2006JD007831, 2007.

Martinez, P. and Brandvold, D. K.: Laboratory and field measurements of $\mathrm{NO}_{\mathrm{x}}$ produced from corona discharges, Atmos. Environ., 30, 4177-4182, 1996.

Marufu, L., Dentener, F., Lelieveld, J., Andreae, M. O., and Helas, G.: Photochemistry of the African troposphere: Influence of biomass-burning emissions, J. Geophys. Res., 105, $14513-$ 14 530, 2000.

McCormick, M. P.: SAGE II: An overview, Adv. Space Res., 7, 219-226, 1987.

Meena, G. S., Bhosale, C. S., and Jadhav, D. B.: Influence of tropospheric clouds on ground-based measurements of stratospheric trace gases at Tropical station, Pune, Atmos. Environ., 38, 34593468, 2004.

Meijer, E. W., van Velthoven, P. F. J., Thompson, A. M., Pfister, L., Schlager, H., Schulte, P., and Kelder, H.: Model calculations of the impact of $\mathrm{NO}_{\mathrm{X}}$ from air traffic, lightning, and surface emissions, compared with measurements, J. Geophys. Res., 105, 3833-3850, doi:10.1029/1999JD901052, 2000.

Meijer, E. W., van Velthoven, P. F. J., Brunner, D. W., Huntrieser, H., and Kelder, H.: Improvement and evaluation of the parameterisation of nitrogen oxide production by lightning, Phys. Chem. Earth, 26, 577-583, 2001.

Meyer-Arnek, J., Ladstätter-Weißenmayer, A., Richter, A., Wittrock, F., and Burrows, J. P.: A study of the trace gas columns of $\mathrm{O}_{3}, \mathrm{NO}_{2}$, and $\mathrm{HCHO}$ over Africa in September 1997, Faraday Discuss., 130, 387-405, doi:10.1039/b502106p, 2005.

Meyer, C. P., Elsworth, C. M., and Galbally, I. E.: Water vapor interference in the measurement of ozone in ambient air by ultraviolet absorption, Rev. Sci. Instrum., 62, 223-228, 1991.

Michalon, N., Nassif, A., Saouri, T., Royer, J. F., and Pontikis, C. A.: Contribution to the climatological study of lightning, Geophys. Res. Lett., 26, 3097-3100, 1999.

Mickley, L. J., Murti, P. P., Jacob, D. J., Logan, J. A., Koch, D. M., and Rind, D.: Radiative forcing from tropospheric ozone calculated with a unified chemistry-climate model, J. Geophys. Res., 104, 30 153-30 172, 1999.

Mickley, L. J., Jacob, D. J., and Rind, D.: Uncertainty in preindustrial abundance of tropospheric ozone: implications for radiative forcing calculations, J. Geophys. Res., 106, 3389-3399, 2001.

Minikin, A., Petzold, A., Ström, J., Krejci, R., Seifert, M., van Velthoven, P., Schlager, H., and Schumann, U.: Aircraft observations of the upper tropospheric fine particle aerosol in the Northern and Southern Hemispheres at midlatitudes, Geophys. Res. Lett., 30, 1503, doi:10.1029/2002GL016458, 2003.

Mishin, E.: Ozone layer perturbation by a single blue jet, Geophys. Res. Lett., 24, 1919-1922, 1997.

Mitzeva, R., Latham, J., and Petrova, S.: A comparative modeling study of the early electrical development of maritime and continental thunderstorms, Atmos. Res., 82, 26-36, doi:10.1016/j.atmosres.2005.01.006, 2006.

Molinari, J., Moore, P., and Idone, V.: Convective structure of hurricanes as revealed by lightning locations, Mon. Wea. Rev., 127, 520-534, 1999.

Molinié, J. and Pontikis, C. A.: A climatological study of tropi- 
cal thunderstorm clouds and lightning frequencies on the French Guyana coast, Geophys. Res. Lett., 22, 1085-1088, 1995.

Moxim, W. J., Levy II, H., and Kasibhatla, P. S.: Simulated global tropospheric PAN: its transport and impact on $\mathrm{NO}_{\mathrm{x}}$, J. Geophys. Res., 101, 12621-12 638, 1996.

Moxim, W. J. and Levy II, H.: A model analysis of the tropical South Atlantic Ocean tropospheric ozone maximum: the interaction of transport and chemistry, J. Geophys. Res., 105, 1739317415, 2000.

Mueller, J. F. and Stavrakou, T.: Inversion of CO and NOx emissions using the adjoint of the IMAGES model, Atmos. Chem. Phys., 5, 1157-1186, 2005, http://www.atmos-chem-phys.net/5/1157/2005/.

Mullendore, G. L., Durran, D. R., and Holton, J. R.: Crosstropopause tracer transport in midlatitude convection, J. Geophys. Res., 110, D06113, doi:10.1029/2004JD005059, 2005.

Müller, J. F. and Brasseur, G.: IMAGES: A three-dimensional chemical transport model of the global troposphere, J. Geophys. Res., 100, 16 445-16 490, doi:10.1029/94JD03254, 1995.

Müller, J. F. and Brasseur, G.: Sources of upper tropospheric $\mathrm{HO}_{\mathrm{x}}$ : A three-dimensional study, J. Geophys. Res., 104, 1705-1716, doi:10.1029/1998JD100005, 1999.

Müller, J. F. and Stavrakou, T.: Inversion of $\mathrm{CO}$ and $\mathrm{NO}_{\mathrm{x}}$ emissions using the adjoint of the IMAGES model, Atmos. Chem. Phys., 5, 1157-1186, 2005,

http://www.atmos-chem-phys.net/5/1157/2005/.

Munro, R., Anderson, C., Callies, J., Corpaccioli, E., Eisinger, M., Lang, R., Lefebvre, A., Livschitz, Y., and Albiñana, A. P.: GOME-2 on METOP, paper presented at Atmospheric Science Conference, 8-12 May 2006, http://earth.esa.int/workshops/ atmos2006/, ESRIN, SP-628, Frascati, Italy, 2006.

Murazaki, K. and Hess, P.: How does climate change contribute to surface ozone change over the United States?, J. Geophys. Res., 111, D05301, doi:10.1029/2005JD005873, 2006.

Murphy, D. M., Fahey, D. W., Proffitt, M. H., Liu, S. C., Chan, K. R., Eubank, C. S., Kawa, S. R., and Kelly, K.: Reactive nitrogen and its correlation with ozone in the lower stratosphere and upper troposphere, J. Geophys. Res., 98, 8751-8773, doi:10.1029/92JD00681, 1993.

Murphy, D. M. and Fahey, D. W.: An estimate of the flux of stratospheric reactive nitrogen and ozone into the troposphere, J. Geophys. Res., 99, 5325-5332, 1994.

Mushtak, V. C., Williams, E. R., and Boccippio, D. J.: Latitudinal variations of cloud base height and lightning parameters in the tropics, Atmos. Res., 76, 222-230, 2005.

Naik, V., Mauzerall, D., Horowitz, L., Schmeltekopf, M. D., Ramaswamy, V., and Oppenheimer, M.: Net radiative forcing due to changes in regional emissions of tropospheric ozone precursors, J. Geophys. Res., 110, 1-14, doi:10.1029/2005JD005908, 2005.

Navarro-González, R., Villagrán-Muniz, M., Sobral, H., Molina, L. T., and Molina, M. J.: The physical mechanism of nitric oxide formation in simulated lightning, Geophys. Res. Lett., 28, 38673870, doi:10.1029/2001GL013170, 2001.

Nesbitt, S. W., Zhang, R., and Orville, R. E.: Seasonal and global $\mathrm{NO}_{\mathrm{x}}$ production by lightning estimated from the Optical Transient Detector (OTD), Tellus, 52B, 1206-1215, 2000.

Nickolaenko, A. P., Hayakawa, M., and Sekiguchi, M.: Variations in global thunderstorm activity inferred from the OTD records,
Geophys. Res. Lett., 33, L06823, doi:10.1029/2005GL024884, 2006.

Nober, F. J. and Graf, H. F.: A new convective cloud field model based on principles of self-organisation, Atmos. Chem. Phys., 5, 2749-2759, 2005,

http://www.atmos-chem-phys.net/5/2749/2005/.

Noble, C. M. M., Beasley, W. H., Postawko, S. E., and Light, T. E. L.: Coincident observations of lightning by the FORTE photodiode detector, the New Mexico Tech Lightning Mapping Array and the NLDN during STEPS, Geophys. Res. Lett., 31, L07106, doi:10.1029/2003GL018989, 2004.

Noxon, J. F.: Atmospheric nitrogen fixation by lightning, Geophys. Res. Lett., 3, 463-465, 1976.

Noxon, J. F.: Tropospheric $\mathrm{NO}_{2}$, J. Geophys. Res., 83, 3051-3057, 1978.

Olivier, J. G. J., Bouwman, A. F., Van der Hoek, K. W., and Berdowski, J. J. M.: Global air emission inventories for anthropogenic sources of $\mathrm{NO}_{\mathrm{x}}, \mathrm{NH}_{3}$ and $\mathrm{N}_{2} \mathrm{O}$ in 1990, Environ. Pollut., 102, 135-148, 1998.

Olivier, J. G. J., Van Aardenne, J. A., Dentener, F., Ganzeveld, L., and Peters, J. A. H. W.: Recent trends in global greenhouse gas emissions: regional trends and spatial distribution of key sources, in: Non- $\mathrm{CO}_{2}$ Greenhouse Gases (NCGG-4), edited by: van Amstel, A., pp. 325-330, Millpress, Rotterdam, 2005.

Olson, J. R., Crawford, J. H., Chen, G., Brune, W. H., Faloona, I. C., Tan, D., Harder, H., and Martinez, M.: A reevaluation of airborne $\mathrm{HO}_{\mathrm{x}}$ observations from NASA field campaigns, J. Geophys. Res., 111, D10301, doi:10.1029/2005JD006617, 2006.

Orville, R. E.: Ozone production during thunderstorms, measured by the absorption of ultraviolet radiation from lightning, J. Geophys. Res., 72, 3557-3561, 1967.

Orville, R. E.: A high-speed time-resolved spectroscopic study of the lightning return stroke. Parts I-III, J. Atmos. Sci., 25, 827856, 1968.

Orville, R. E. and Spencer, D. W.: Global lightning flash frequency, Mon. Wea. Rev., 107, 934-943, 1979.

Orville, R. E.: Peak-current variations of lightning return strokes as a function of latitude, Nature, 343, 149-151, 1990.

Orville, R. E.: Cloud-to-ground lightning flash characteristics in the contiguous United States: 1989-1991, J. Geophys. Res., 99, 10 833-10 842, doi:10.1029/93JD02914, 1994.

Orville, R. E.: Comments on "Large peak current cloud-to-ground lightning flashes during the summer months in the contiguous United States", Mon. Wea. Rev., 127, 1937-1938, 1999.

Orville, R. E., Huffines, G. R., Burrows, W. R., Holle, R. L., and Cummins, K. L.: The North American lightning detection network (NALDN) - First results: 1998-2000, Mon. Wea. Rev., 130, 2098-2109, 2002.

Ott, L., Pickering, K., Stenchikov, G., Lin, R.-F., Ridley, B., Loewenstein, M., Lopez, J., and Richard, E.: The impact of lightning $\mathrm{NO}_{\mathrm{x}}$ production on atmospheric chemistry in a CRYSTALFACE thunderstorm simulated using a 3-D cloud-scale chemical transport model (2005 - LIGHTNING), paper presented at AMS Conference on Meteorological Applications of Lightning Data (abstract), 2005.

Ott, L. E., Pickering, K. E., Stenchhikov, G. L., Huntrieser, $\mathrm{H}$, and Schumann, U.: Effects of lightning $\mathrm{NO}_{\mathrm{x}}$ production during the 21 July European Lightning Nitrogen Oxides Project storm studied with a three-dimensional cloud-scale 
chemical transport model, J. Geophys. Res., 112, D05307, doi:10.1029/2006JD007365, 2007.

Paetzold, H. K. and Regener, E.: Ozon in der Erdatmosphäre, in: Handbuch der Physik, Vol. 48, Geophysik II, edited by: Flügge, S., pp. 370-426, Springer, Berlin, 1957.

Pätz, H.-W., Volz-Thomas, A., Hegglin, M. I., Brunner, D., Fischer, $\mathrm{H}$., and Schmidt, U.: In-situ comparison of the $\mathrm{NO}_{\mathrm{y}}$ instruments flown in MOZAIC and SPURT, Atmos. Chem. Phys., 6, 24012410, 2006,

http://www.atmos-chem-phys.net/6/2401/2006/.

PEM-Tropics-A-Science-Team: Pacific Exploratory Measurements in the Tropics (PEM-Tropics A), J. Geophys. Res., 104, 55655876, 1999.

Penner, J. E., Atherton, C. S., Dignon, J., Ghan, S. J., Walton, J. J., and Hameed, S.: Tropospheric nitrogen: A three-dimensional study of sources, distributions, and deposition, J. Geophys. Res., 96, 959-990, doi:10.1029/90JD02228, 1991.

Penner, J. E., Bergmann, D. J., Walton, J. J., Kinnison, D., Prather, M. J., Rotman, D., Price, C., Pickering, K. E., and Baughcum, S. L.: An evaluation of upper troposphere $\mathrm{NO}_{\mathrm{x}}$ with two models, J. Geophys. Res., 103, 22 097-22 114, doi:10.1029/98JD01565, 1998.

Peters, M. W., Krol, M., Dentener, F., Thompson, A. M., and Lelieveld, J.: Chemistry-transport modeling of the satellite observed distribution of tropical tropospheric ozone, Atmos. Chem. Phys., 2, 103-120, 2002,

http://www.atmos-chem-phys.net/2/103/2002/.

Petersen, W. A. and Rutledge, S. A.: Some characteristics of cloudto-ground lightning in tropical northern Australia, J. Geophys. Res., 97, 11 553-11 560, 1992.

Petersen, W. A. and Rutledge, S. A.: On the relationship between cloud-to-ground lightning and convective rainfall, J. Geophys. Res., 103, 14 025-14 040, doi:10.1029/97JD02064, 1998.

Petersen, W. A., Christian, H. J., and Rutledge, S. A.: TRMM observations of the global relationship between ice water content and lightning, Geophys. Res. Lett., 32, 1-4, doi:10.1029/2005GL023236, 2005.

Petry, H., Hendricks, J., Moellhoff, M., Lippert, E., Meier, A., Ebel, A., and Sausen, R.: Chemical conversion of subsonic aircraft emissions in the dispersing plume: calculation of effective emission indices, J. Geophys. Res., 103, 5759-5772, 1998.

Peyrous, R. and Lapeyre, R. M.: Gaseous products created by electrical discharges in the atmosphere and condensation nuclei resulting from gaseous phase reactions, Atmos. Environ., 16, 959968, 1982

Pfeilsticker, K., Erle, F., Funk, O., Marquard, L., Wagner, T., and Platt, U.: Optical path modifications due to tropospheric clouds: Implications for zenith sky measurements of stratospheric gases, J. Geophys. Res., 103, 25 323-25 336, doi:10.1029/98JD01803, 1998.

Pickering, K. E., Thompson, A. M., Scala, J. R., Tao, W.-K., Simpson, J., and Garstang, M.: Photochemical ozone production in tropical squall line convection during NASA Global Tropospheric Experiment/Amazon Boundary Layer Experiment 2A, J. Geophys. Res., 96, 3099-3114, 1991.

Pickering, K. E., Thompson, A. M., Tao, W. K., and Kucsera, T. L.: Upper tropospheric ozone production following mesoscale convection during STEP/EMEX, J. Geophys. Res., 98, 8737-8749, doi:10.1029/93JD00875, 1993.
Pickering, K. E., Thompson, A. M., Wang, Y., et al.: Convective transport of biomass burning emissions over Brazil during TRACE A, J. Geophys. Res., 101, 23 993-24012, doi:10.1029/96JD00346, 1996.

Pickering, K. E., Wang, Y., Tao, W. K., Price, C., and Müller, J. F.: Vertical distributions of lightning $\mathrm{NO}_{\mathrm{x}}$ for use in regional and global chemical transport models, J. Geophys. Res., 103, 31203 31 216, doi:10.1029/98JD02651, 1998.

Piepgrass, M. V., Krider, E. P., and Moore, C. B.: Lightning and surface rainfall during Florida thunderstorms, J. Geophys. Res., 87, 11 193-12 001, 1982.

Pierce, E. T.: Latitudinal variation of lightning parameters, J. Appl. Meteorol., 9, 194-195, 1970.

Pinto, I. R. C. A. and Pinto Jr., O.: Cloud-to-ground lightning distributions in Brazil, J. Atmos. Solar-Terr. Phys., 65, 733-737, 2003.

Pinto Jr., O., Naccarato, K. P., Pinto, I. R. C. A., Fernandes, W. A., and Pinto Neto, O.: Monthly distribution of cloud-to-ground lightning flashes as observed by lightning location systems, Geophys. Res. Lett., 33, L09811, doi:10.1029/2006GL026081, 2006.

Platt, U., Marquard, L., Wagner, T., and Perner, D.: Corrections for zenith scattered light DOAS, Geophys. Res. Lett., 24, 17591762, doi:10.1029/97GL01693, 1997.

Pommereau, J.-P., Garnier, A., Held, G., et al.: An overview of the HIBISCUS campaign, Atmos. Chem. Phys. Discuss., 7, 2389 2475, 2007, http://www.atmos-chem-phys-discuss.net/7/2389/2007/.

Poulida, O., Dickerson, R. R., and Heymsfield, A.: Stratospheretroposphere exchange in a midlatitude mesoscale convective complex. 1. Observations, J. Geophys. Res., 101, 6823-6936, 1996.

Prather, M. J. and Jacob, D. J.: A persistent imbalance in $\mathrm{HO}_{\mathrm{x}}$ and $\mathrm{NO}_{\mathrm{x}}$ photochemistry of the upper troposphere driven by deep tropical convection, Geophys. Res. Lett., 24, 3189-3192, 1997.

Prentice, S. A. and MacKerras, D.: The ratio of cloud to cloudground lightning flashes in thunderstorms, J. Appl. Meteorol., 16, 545-550, 1977.

Price, C. and Rind, D.: A simple lightning parameterization for calculating global lightning distributions, J. Geophys. Res., 97, 9919-9933, doi:10.1029/92JD00719, 1992.

Price, C.: Global surface temperatures and the atmospheric electrical circuit, Geophys. Res. Lett., 20, 1363-1366, 1993.

Price, C. and Rind, D.: What determines the cloud-to-ground lightning fraction in thunderstorms?, Geophys. Res. Lett., 20, $463-$ 466, doi:10.1029/93GL00226, 1993.

Price, C. and Rind, D.: Possible implications of global climate change on global lightning distributions and frequencies, J. Geophys. Res., 99, 10 823-10 831, doi:10.1029/94JD00019, 1994a.

Price, C. and Rind, D.: The impact of a $2 \times \mathrm{CO}_{2}$ climate on lightning-caused fires, J. Climate, 7, 1484-1494, 1994b.

Price, C., Penner, J., and Prather, M.: $\mathrm{NO}_{\mathrm{x}}$ from lightning. 2. Constraints from the global atmospheric electric circuit, J. Geophys. Res., 102, 5943-5951, doi:10.1029/96JD02551, 1997a.

Price, C., Penner, J., and Prather, M.: $\mathrm{NO}_{\mathrm{x}}$ from lightning. 1. Global distribution based on lightning physics, J. Geophys. Res., 102, 5929-5941, doi:10.1029/96JD03504, 1997b.

Price, C.: Evidence for a link between global lightning activity and upper tropospheric water vapour, Nature, 406, 290-293, 2000.

Price, C. and Asfur, M.: Can lightning observations be used as an 
indicator of upper-tropospheric water vapor availability?, Bull. Am. Meteor. Soc., 87, 291-314, 2006.

Price, C. and Federmesser, B.: Lightning-rainfall relationships in Mediterranean winter thunderstorms, Geophys. Res. Lett., 33, L07813, doi:10.1029/2005GL024794, 2006.

Price, C., Pechony, O., and Greenberg, E.: Schumann resonance in lightning research, J. Lightning Res., 1, 1-15, http://www.jolr. org, 2007.

Proctor, D. E.: Regions where lightning flashes began, J. Geophys. Res., 96, 5099-5112, 1991.

Rahman, M., Cooray, V., Rakov, V. A., Uman, M. A., Liyanage, P., DeCarlo, B. A., Jerauld, J., and Olsen III, R. C.: Measurements of $\mathrm{NO}_{\mathrm{x}}$ produced by rocket-triggered lightning, Geophys. Res. Lett., 34, L03816, doi:10.1029/2006GL027956, 2007.

Rakov, V. A. and Uman, M. A.: Lightning - Physics and Effects, 687 pp., Cambridge Univ. Press, Cambridge, UK, 2003.

Randriambelo, T., Baray, J. L., Baldy, S., Bremaud, P., and Cautenet, S.: A case study of extreme tropospheric ozone contamination in the tropics using in-situ, satellite and meteorological data, Geophys. Res. Lett., 26, 1287-1290, 1999.

Rasch, P. J., Boville, B. A., and Brasseur, G. P.: A threedimensional general circulation model with coupled chemistry for the middle atmosphere, J. Geophys. Res., 100, 9041-9072, doi:10.1029/95JD00019, 1995.

Rasch, P. J., Mahowald, N. M., and Eaton, B. E.: Representations of transport, convection and the hydrologic cycle in chemical transport models: Implications for the modeling of short lived and soluble species, J. Geophys. Res., 102, 28 127-28 138, 1997.

Redelsperger, J.-L., Thorncroft, C. D., Diedhiouc, A., Lebel, T., Parker, D. J., and Polcher, J.: African Monsoon Multidisciplinary Analysis: An international research project and field campaign, Bull. AMS, 87, 1739-1746, doi:10.1175/BAMS-8712-1739, 2006.

Reeve, N. and Toumi, R.: Lightning activity as an indicator of climate change, Q. J. Roy. Meteor. Soc., 125, 893-903, 1999.

Reiter, R.: On the causal relation between nitrogen-oxygen compounds in the troposphere and atmospheric electricity, Tellus, 22, $122-135,1970$.

Ricciardulli, L. and Sardeshmukh, P. D.: Local time- and space scales of organised tropical deep convection, J. Climate, 15, 2775-2790, 2002.

Richter, A. and Burrows, J. P.: Tropospheric $\mathrm{NO}_{2}$ from GOME measurements, Adv. Space Res., 29, 1673-1683, 2002.

Richter, A., Eyring, V., Burrows, J. P., Bovensmann, H., Lauer, A., Sierk, B., and Crutzen, P. J.: Satellite measurements of $\mathrm{NO}_{2}$ from international shipping emissions, Geophys. Res. Lett., 31, L23110, doi:10.1029/2004GL020822, 2004.

Richter, A., Burrows, J. P., Nuess, H., Granier, C., and Niemeier, U.: Increase in tropospheric nitrogen dioxide over China observed from space, Nature, 437, 129-132, 2005.

Ridley, B., Ott, L., Pickering, K., et al.: Florida thunderstorms: A faucet of reactive nitrogen to the upper troposphere, J. Geophys. Res., 109, 1-19, doi:10.1029/2004JD004769, 2004.

Ridley, B. A., Walega, J. G., Dye, J. E., and Grahek, F. E.: Distributions of $\mathrm{NO}, \mathrm{NO}_{\mathrm{x}}, \mathrm{NO}_{\mathrm{y}}$, and $\mathrm{O}_{3}$ to $12 \mathrm{~km}$ altitude during the summer monsoon season over New Mexico, J. Geophys. Res., 99, 25 519-25 534, doi:10.1029/94JD02210, 1994.

Ridley, B. A., Dye, J. E., Walega, J. G., Zheng, J., Grahek, F. E., and Rison, W.: On the production of active nitrogen by thunder- storms over New Mexico, J. Geophys. Res., 101, 20 985-21 005, doi:10.1029/96JD01706, 1996.

Ridley, B. A., Pickering, K. E., and Dye, J. E.: Comments on the parameterization of lightning-produced NO in global chemistrytransport models, Atmos. Environ., 39, 6184-6187, 2005.

Ridley, B. A., Avery, M. A., Plant, J. V., Vay, S. A., Montzka, D. D., Weinheimer, A. J., Knapp, D. J., Dye, J. E., and Richard, E. C.: Sampling of chemical constituents in electrically active convective systems: Results and cautions, J. Atmos. Chem., 54, 1-20, doi:10.1007/s10874-005-9007-5, 2006.

Rind, D., Lerner, J., and Zawodny, J.: A complementary analysis for SAGE II data profiles, Geophys. Res. Lett., 32, L07812, doi:10.1029/2005GL022550, 2005.

Rivière, E. D., Marécal, V., Larsen, N., and Cautenet, S.: Modelling study of the impact of deep convection on the UTLS air composition - Part 2: Ozone budget in the TTL, Atmos. Chem. Phys., 6, 1585-1598, 2006, http://www.atmos-chem-phys.net/6/1585/2006/.

Roelofs, G.-J. and Lelieveld, J.: Distribution and budget of $\mathrm{O}_{3}$ in the troposphere calculated with a chemistry general circulation model, J. Geophys. Res., 100, 20 983-20 998, 1995.

Roelofs, G.-J. and Lelieveld, J.: Tropospheric ozone simulation with a chemistry-general circulation model: influence of higher hydrocarbon chemistry, J. Geophys. Res., 105, 22 697-22 712, 2000.

Roelofs, G. J., Scheeren, H. A., Heland, J., Ziereis, H., and Lelieveld, J.: A model study of ozone in the eastern Mediterranean free troposphere during MINOS (August 2001), Atmos. Chem. Phys., 3, 1199-1210, 2003, http://www.atmos-chem-phys.net/3/1199/2003/.

Rohrer, F., Brüning, D., and Ehhalt, D. H.: Tropospheric mixing ratios of NO obtained during TROPOZ II in the latitude region $67^{\circ}$ N-56 ${ }^{\circ}$ S, J. Geophys. Res., 102, 25 429-25 449, 1997.

Rohrer, F. and Berresheim, H.: Strong correlation between levels of tropospheric hydroxyl radicals and solar ultraviolet radiation, Nature, 442, 184-187, doi:10.1038/nature04924, 2006.

Rorig, M. L. and Ferguson, S. A.: The 2000 fire season: Lightningcaused fires, J. Appl. Meteorol., 41, 786-791, doi:10.1175/15200450, 2002.

Rosenfeld, D. and Lensky, I. M.: Satellite-based insights into precipitation formation processes in continental and maritime convective clouds, Bull. AMS, 79, 2457-2476, 1998.

Rubin, M. B.: The history of ozone. The Schönbein period, 19391868., Bull. Hist. Chem., 26, 40-56, 2001.

Russell III, J. M., Gordley, L. L., Park, J. H., Drayson, S. R., Hesketh, W. D., Cicerone, R. J., Tuck, A. F., Frederick, J. E., Harries, J. E., and Crutzen, P. J.: The Halogen Occultation Experiment, J. Geophys. Res., 98, 10777-10797, doi:10.1029/93JD00799, 1993.

Russell, P. B., Pfister, L., and Selkirk, H. B.: The Tropical Experiment of the Stratosphere-Troposphere Exchange Project (STEP): Science objectives, operations, and summary findings, J. Geophys. Res., 98, 8563-8589, 1993.

Rycroft, M. J., Israelsson, S., and Price, C.: The global atmospheric electrical circuit, solar activity and climate change, J. Atmos. Solar-Terr. Phys., 62, 1563-1576, 2000.

Ryu, J.-H. and Jenkins, G. S.: Lightning-tropospheric ozone connections: EOF analysis of TCO and lightning data, Atmos. Environ., 39, 5799-5805, 2005. 
Saba, M. M. F., Ballarotti, M. G., and Pinto Jr., O.: Negative cloud-to-ground lightning properties from highspeed video observations, J. Geophys. Res., 111, D03101, doi:10.1029/2005JD006415, 2006a.

Saba, M. M. F., Pinto Jr., O., and Ballarotti, M. G.: Relation between lightning return stroke peak current and following continuing current, Geophys. Res. Lett., 33, L23807, doi:10.1029/2006GL027455, 2006b.

Sanderson, M. G., Collins, W. J., Johnson, C. E., and Derwent, R. G.: Present and future acid deposition to ecosystems: The effect of climate change, Atmos. Environ., 40, 1275-1283, 2006.

Sandholm, S. T., Bradshaw, J. D., Dorris, K. S., Rodgers, M. O., and Davis, D. D.: An airborne compatible photofragmentation two-photon laser-induced fluorescence instrument for measuring background tropospheric levels of $\mathrm{NO}, \mathrm{NO}_{\mathrm{x}}$ and $\mathrm{NO}_{2}$, J. Geophys. Res., 95, $10155-10161,1990$.

Sato, M. and Fukunishi, H.: Global sprite occurrence locations and rates derived from triangulation of transient Schumann resonance events, Geophys. Res. Lett., 30, 1859, doi:10.1029/2003GL017291, 2003.

Satori, G. and Zieger, B.: Spectral characteristics of Schumann resonances observed in Central Europe J. Geophys. Res., 101, 29663-29 669, 1996.

Saunders, C. P. R.: A review of thunderstorm electrification processes, J. Appl. Meteorol., 32, 642-655, 1993.

Sausen, R., Isaksen, I., Hauglustaine, D., et al.: Aviation radiative forcing in 2000: An update on IPCC (1999), Meteorol. Z., 14, 555-561, doi:10.1127/0941-2948/2005/0049, 2005.

Sauvage, B., Martin, R. V., van Donkelaar, A., Liu, X., Chance, K., Jaeglé, L., Palmer, P. I., Wu, S., and Fu, T.-M.: Remote sensed and in situ constraints on processes affecting tropical tropospheric ozone, Atmos. Chem. Phys., 7, 815-838, 2007a

Sauvage, B., Martin, R. V., van Donkelaar, A., and Ziemke, J. R.: Quantification of the factors controlling tropical tropospheric ozone and the South Atlantic maximum, J. Geophys. Res., 112, D11309, doi:10.1029/2006JD008008, 2007b.

Savage, N. H., Law, K. S., Pyle, J. A., Richter, A., Nüß, N., and Burrows, J. P.: Using GOME $\mathrm{NO}_{2}$ satellite data to examine regional differences in TOMCAT model performance, Atmos. Chem. Phys., 4, 1895-1912, 2004, http://www.atmos-chem-phys.net/4/1895/2004/.

Savoie, D. L., Prospero, J. M., Merrill, J. T., and Uematsu, M.: Nitrate in the atmospheric boundary layer of the tropical South Pacific: Implications regarding sources and transport, J. Atmos. Chem., 8, 391-415, doi:10.1007/BF00052712, 1989.

Scheeren, H. A., Lelieveld, J., Roelofs, G. J., et al.: The impact of monsoon outflow from India and Southeast Asia in the upper troposphere over the eastern Mediterranean, Atmos. Chem. Phys., 3, 1589-1608, 2003, http://www.atmos-chem-phys.net/3/1589/2003/.

Schlager, H., Konopka, P., Schulte, P., Schumann, U., Ziereis, H., Arnold, F., Klemm, M., Hagen, D. E., Whitefield, P. D., and Ovarlez, J.: In situ observations of air traffic emission signatures in the North Atlantic flight corridor, J. Geophys. Res., 102, 10739-10750, 1997.

Schlager, H., Schulte, P., Flatoy, F., Slemr, F., van Velthoven, P., Ziereis, H., and Schumann, U.: Regional nitric oxide enhancements in the North Atlantic flight corridor observed and modeled during POLINAT 2 - a case study, Geophys. Res. Lett., 26,
3061-3064, 1999.

Schmidt, K., Betz, H.-D., Oettinger, W. P., Wirz, M., Hoeller, H., Fehr, T., Pinto Jr., O., Naccarato, K. P., and Held, G.: A comparative analysis of lightning data during the EU Brazil TROCCINOX/TroCCiBras campaign, paper presented at 8th International Symposium on Lightning Protection (SIPDA), 21-25 November, USP, São Paulo, Brazil, 2005.

Schultz, M. G., Jacob, D. J., Wang, Y., et al.: On the origin of tropospheric ozone and $\mathrm{NO}_{\mathrm{x}}$ over the tropical South Pacific, J. Geophys. Res., 104, 5829-5843, 1999.

Schultz, M. G. and Bey, I.: Numerical modelling of long-range pollution transport, in: Intercontinental Transport of Air Pollution, edited by: Stohl, A., pp. 197-223, Springer, Berlin, 2004.

Schulz, W., Cummins, K., Diendorfer, G., and Dorninger, M.: Cloud-to-ground lightning in Austria: A 10-year study using data from a lightning location system, J. Geophys. Res., 110, D09101, doi:10.1029/2004JD005332, 2005.

Schumann, U., Schlager, H., Arnold, F., Ovarlez, J., Kelder, H., Hov, Ø., Hayman, G., Isaksen, I. S. A., Staehelin, J., and Whitefield, P. D.: Pollution from aircraft emissions in the North Atlantic flight corridor: Overview on the POLINAT projects, J. Geophys. Res., 105, 3605-3631, 2000.

Schumann, U., Ström, J., Arnold, F., Berntsen, T. K., de F. Forster, P. M., Gayet, J.-F., and Hauglustaine, D.: Aviation impact on atmospheric composition and climate, in: European Research in the Stratosphere 1996-2000, Chapter 7, edited by: Amanatidis, G. T. and Harris, N. R. P., pp. 257-307, European Commission, Brussels, EUR 19867, 2001.

Schumann, U., Baehr, J., and Schlager, H.: Ozone and ozone precursors influenced by tropical convection over South America, in: Proceedings Quadrennial Ozone Symposium, vol. I, edited by: Zerefos, C., pp. 283-284, Kos, Greece, 2004a.

Schumann, U., Huntrieser, H., Schlager, H., Bugliaro, L., Gatzen, C., and Hoeller, H.: Nitrogen Oxides from thunderstorms- Results from experiments over Europe and the Continental Tropics, paper presented at Deutsch-ÖsterreichischSchweizerische Meteorologen-Tagung (DACH), Deutsche Meteorologische Gesellschaft, Karlsruhe, Germany, 7-10 September 2004, http://elib.dlr.de/10188/, 2004b.

Schumann, U., Kurz, C., Schlager, H., Huntrieser, H., Emmons, L., Labrador, L., Meijer, E., Ulanovsky, A., and Viciani, S.: Towards a robust estimate of the global lightning nitrogen oxides source rate and its error bound, paper presented at Conference on Atmospheric Science, http://earth.esa.int/atmos2006/, ESRIN, SP628, Frascati, Italy, 8-12 May 2006.

Schumann, W. O.: Über die strahlungslosen Eigenschwingungen einer leitenden Kugel, die von einer Luftschicht und einer Ionosphärenhülle umgeben ist, Z. Naturforsch., 7A, 149-154, 1952.

Shantla, A. and Moore, C. B.: Ozone and point discharge measurements under thunderclouds, J. Geophys. Res., 77, 4500-4510, 1972.

Shao, X.-M., Stanley, M., Regan, A., Harlin, J., Pongratz, M., and Stock, M.: Total lightning observations with the new and improved Los Alamos Sferic Array (LASA), J. Atmos. Ocean. Technol., 23, 1273-1288, 2006.

Shao, X. M. and Krehbiel, P. R.: The spatial and temporal development of intracloud lightning, J. Geophys. Res., 101, 26641$26668,1996$. 
Shepon, A., Gildor, H., Labrador, L. J., Butler, T., Ganzeveld, L. N., and Lawrence, M. G.: Global reactive nitrogen deposition from lightning $\mathrm{NO}_{\mathrm{x}}$, J. Geophys. Res., 112, D06304, doi:10.1029/2006JD007458, 2007.

Sherwood, S. C., Phillips, V. T. J., and Wettlaufer, J. S.: Small ice crystals and the climatology of lightning, Geophys. Res. Lett., 33, L05804, doi:10.1029/2005GL025242, 2006.

Shindell, D. T., Grenfell, J. L., Rind, D., Grewe, V., and Price, C.: Chemistry-climate interactions in the Goddard Institute for Space Studies general circulation model, 1, Tropospheric chemistry model description and evaluation, J. Geophys. Res., 106, 8047-8076, doi:10.1029/2000JD900704, 2001.

Shindell, D. T., Faluvegi, G., and Bell, N.: Preindustrial-to-presentday radiative forcing by tropospheric ozone from improved simulations with the GISS chemistry-climate GCM, Atmos. Chem. Phys., 3, 1675-1702, 2003,

http://www.atmos-chem-phys.net/3/1675/2003/.

Shindell, D. T., Faluvegi, G., Unger, N., Aguilar, E., Schmidt, G. A., Koch, D. M., Bauer, S. E., and Miller, R. L.: Simulations of preindustrial, present-day, and 2100 conditions in the NASA GISS composition and climate model G-PUCCINI, Atmos. Chem. Phys., 66, 4427-4459, 2006,

http://www.atmos-chem-phys.net/66/4427/2006/.

Singh, H. B., Herlth, D., Kolyer, R., et al.: Reactive nitrogen and ozone over the western Pacific: Distribution, partitioning, and sources, J. Geophys. Res., 101, 1793-1808, doi:10.1029/95JD01029, 1996.

Singh, H. B., Viezee, W., Chen, Y., et al.: Latitudinal distribution of reactive nitrogen in the free troposphere over the Pacific Ocean in late winter/early spring, J. Geophys. Res., 103, 28 237-28 246, 1998.

Singh, H. B., Thompson, A. M., and Schlager, H.: SONEX airborne mission and coordinated POLINAT-2 activity: overview and accomplishments, Geophys. Res. Lett., 26, 3053-3056, doi:10.1029/1999GL900588, 1999.

Singh, H. B., Brune, W. H., Crawford, J. H., Jacob, D. J., and Russell, P. B.: Overview of the summer 2004 Intercontinental Chemical Transport Experiment-North America (INTEX-A), J. Geophys. Res., 111, D24S01, doi:10.1029/2006JD007905, 2006.

Singh, H. B., Salas, L., Herlth, D., et al.: Reactive nitrogen distribution and partitioning in the North American troposphere and lowermost stratosphere, J. Geophys. Res., 112, D12S04, doi:10.1029/2006JD007664, 2007.

Sinha, A. and Toumi, R.: Tropospheric ozone, lightning, and climate change, J. Geophys. Res., 102, 10 667-10 672, 1997.

Sioris, C. E., McLinden, C. A., Martin, R. V., et al.: Vertical profiles of lightning-produced $\mathrm{NO}_{2}$ enhancements in the upper troposphere observed by OSIRIS, Atmos. Chem. Phys. Discuss., 7, 5013-5051, 2007,

http://www.atmos-chem-phys-discuss.net/7/5013/2007/.

Sisterson, D. L. and Liaw, Y. P.: An evaluation of lightning and corona discharges on thunderstorm air and precipitation chemistry, J. Atmos. Chem., 10, 83-96, 1990.

Skamarock, W. C., Powers, J. G., Barth, M., Dye, J. E., Matejka, T., Bartels, D., Baumann, K., Stith, J., Parrish, D. D., and Hubler, G.: Numerical simulations of the July 10 StratosphericTropospheric Experiment: Radiation, Aerosols, and Ozone/Deep Convection Experiment convective system: kinematics and transport, J. Geophys. Res., 105, 19973-19990, 2000.
Skamarock, W. C., Dye, J. E., Defer, E., Barth, M. C., Stith, J. L., Ridley, B. A., and Baumann, K.: Observationaland modeling-based budget of lightning-produced $\mathrm{NO}_{\mathrm{x}}$ in a continental thunderstorm, J. Geophys. Res., 108, 4305, doi:10.1029/2002JD002163, 2003.

Smyshlyaev, S. P., Geller, M. A., and Yudin, V. A.: Sensitivity of model assessments of high-speed civil transport effects on stratospheric ozone resulting from uncertainties in the $\mathrm{NO}_{\mathrm{x}}$ production from lightning, J. Geophys. Res., 104, 26 401-26418, doi:10.1029/1999JD900820, 1999.

Smyth, S., Bradshaw, J., Sandholm, S., et al.: Comparison of free tropospheric western tropospheric western Pacific air mass classification schemes for the PEM-West A experiment, J. Geophys. Res., 101, 1743-1762, doi:10.1029/95JD02861, 1996a.

Smyth, S. B., Sandholm, S. T., Bradshaw, J. D., et al.: Factors influencing the upper free tropospheric distribution of reactive nitrogen over the South Atlantic during the TRACE A experiment, J. Geophys. Res., 101, 24 165-24 186, doi:10.1029/96JD00224, 1996 b.

Song, C. H., Chen, G., Hanna, S. R., Crawford, J., and Davis, D. D.: Dispersion and chemical evolution of ship plumes in the marine boundary layer: Investigation of $\mathrm{O}_{3} / \mathrm{NO}_{\mathrm{y}} / \mathrm{HO}_{\mathrm{x}}$ chemistry, $\mathrm{J}$. Geophys. Res., 108, 4143, doi:10.1029/2002JD002216, 2003.

Soriano, L. R., de Pablo, F., and Tomas, C.: Ten-year study of cloud-to-ground lightning activity in the Iberian Peninsula, J. Atmos. Terr. Phys., 67, 1632-1639, 2006.

Soriano, L. R. and de Pablo, F.: Total flash density and the intracloud/cloud-to-ground lightning ratio over the Iberian Peninsula, J. Geophys. Res., 112, D13114, doi:10.1029/2006JD007624, 2007.

Stark, M. S., Harrison, J. T. H., and Anastasi, C.: Formation of nitrogen oxides by electrical discharges and implications for atmospheric lightning, J. Geophys. Res., 101, 6963-6970, doi:10.1029/95JD03008, 1996.

Staudt, A. C., Jacob, D. J., Logan, J. A., Bachiochi, D., Krishnamurti, T. N., and Poisson, N.: Global chemical model analysis of biomass burning and lightning influences over the South Pacific in austral spring, J. Geophys. Res., 107, 4200, doi:10.1029/2000JD000296, 2002.

Staudt, A. C., Jacob, D. J., Ravetta, F., Logan, J. A., Bachiochi, D., Krishnamurti, T. N., Sandholm, S., Ridley, B., Singh, H. B., and Talbot, B.: Sources and chemistry of nitrogen oxides over the tropical Pacific, J. Geophys. Res., 108, 8239, doi:10.1029/2002JD002139, 2003.

Steiger, S. M., Orville, R. E., and Huffines, G.: Cloud-to-ground lightning characteristics over Houston, Texas: 1989-2000, J. Geophys. Res., 107, 4117, doi:10.1029/2001JD001142, 2002.

Stenke, A. and Grewe, V.: Impact of dynamically induced ozone mini-hole events on PSC formation and chemical ozone destruction, Adv. Space Res., 33, 1062-1067, 2004.

Stevenson, D. S., Doherty, R. M., Sanderson, M. G., Collins, W. J., Johnson, C. E., and Derwent, R. G.: Radiative forcing from aircraft $\mathrm{NO}_{\mathrm{x}}$ emissions: Mechanisms and seasonal dependence, J. Geophys. Res., 109, D17307, doi:10.1029/2004JD004759, 2004.

Stevenson, D. S., Doherty, R., Sanderson, M., Johnson, C. E., Collins, B., and Derwent, R. G.: Impacts of climate change and variability on tropospheric ozone and its precursors, Faraday Discuss., 130, 41-57, doi:10.1039/b417412g, 2005.

Stevenson, D. S., Dentener, F. J., Schultz, M. G., et al.: 
Multimodel ensemble simulations of present-day and nearfuture tropospheric ozone, J. Geophys. Res., 111, D08301, doi:10.1029/2005JD006338, 2006.

Stith, J., Dye, J., Ridley, B., Laroche, P., Defer, E., Baumann, K., Huebler, G., Zerr, R., and Venticinque, M.: NO signatures from lightning flashes, J. Geophys. Res., 104, 16 081-16 089, 1999.

Stockwell, D. Z., Giannakopoulos, C., Plantevin, P. H., Carver, G. D., Chipperfield, M. P., Law, K. S., Pyle, J. A., Shallcross, D. E., and Wang, K. Y.: Modelling $\mathrm{NO}_{\mathrm{x}}$ from lightning and its impact on global chemical fields, Atmos. Environ., 33, 4477-4493, 1999.

Stohl, A., Wernli, H., James, P., Bourqui, M., Forster, C., Liniger, M. A., Seibert, P., and Sprenger, M.: A new perspective of stratosphere-troposphere exchange, Bull. AMS, 84, 1565-1573, 2003.

Stolzenburg, M., Marshall, T. C., Rust, W. D., Bruning, E., MacGorman, D. R., and Hamlin, T.: Electric field values observed near lightning flash initiations, Geophys. Res. Lett., 34, L04804, doi:10.1029/2006GL028777, 2007.

Strand, A. and Hov, O.: A two-dimensional global study of tropospheric ozone production, J. Geophys. Res., 99, 22 877-22 895, 1994.

Sudo, K., Takahashi, M., and Akimoto, H.: CHASER: A global chemical model of the troposphere 2. Model results and evaluation, J. Geophys. Res., 107, 4586, doi:10.1029/2001JD001114, $2002 \mathrm{a}$.

Sudo, K., Takahashi, M., Kurokawa, J. I., and Akimoto, H.: CHASER: A global chemical model of the troposphere 1. Model description, J. Geophys. Res., 107, 4339, doi:10.1029/2001JD001113, 2002b.

Suhre, K., Cammas, J.-P., Nédelec, P., Rosset, R., Marenco, A., and Smit, H. G. J.: Ozone-rich transients in the upper equatorial Atlantic troposphere, Nature 388, 661-663, doi:10.1038/41749, 1997.

Suszcynsky, D. M., Kirkland, M. W., Jacobson, A. R., Franz, R. C., Knox, S. O., Guillen, J. L. L., and Green, J. L.: FORTE observations of simultaneous VHF and optical emissions from lightning: Basic phenomenology, J. Geophys. Res., 105, 21912202, doi:10.1029/1999JD900993, 2000.

Takahashi, T.: Thunderstorm electrification - A numerical study, J. Atmos. Sci., 41, 2541-2557, 1984.

Takayabu, Y. N.: Rain-yield per flash calculated from TRMM PR and LIS data and its relationship to the contribution of tall convective rain, Geophys. Res. Lett., 33, L18705, doi:10.1029/2006GL027531, 2006.

Talbot, R. W., Dibb, J. E., Scheuer, E. M., et al.: Reactive nitrogen budget during the NASA SONEX mission, Geophys. Res. Lett., 26, 3057-3060, doi:10.1029/1999GL900589, 1999.

Thakur, A. N., Singh, H. B., Mariani, P., Chen, Y., Wang, Y., Jacob, D. J., Brasseur, G., Mueller, J.-F., and Lawrence, M.: Distribution of reactive nitrogen species in the remote free troposphere: data and model comparisons, Atmos. Environ., 33, 1403-1422, 1999.

Thery, C., Laroche, P., and Blanchet, P.: Lightning activity during EULINOX and estimation of $\mathrm{NO}_{\mathrm{x}}$ production by flashes, in: EULINOX - The European Lightning Nitrogen Oxides Project, edited by: Höller, H. and Schumann, U., pp. 129-145, Deutsches Zentrum für Luft- und Raumfahrt, DLR-FB 2000-28, Köln, Germany, 2000.
Thery, C.: Evaluation of LPATS data using VHF interferometric observations of lightning flashes during the Eulinox experiment, Atmos. Res., 56, 397-409, 2001.

Thomas, R. J., Krehbiel, P. R., Rison, W., Hamlin, T., Boccippio, D. J., Goodman, S. J., and Christian, H. J.: Comparison of ground-based 3-dimensional lightning mapping observations with satellite-based LIS observations in Oklahoma, Geophys. Res. Lett., 27, 1703-1706, doi:10.1029/1999GL010845, 2000.

Thomas, R. J., Krehbiel, P. R., Rison, W., Hamlin, T., Harlin, J., and Shown, D.: Observations of VHF source powers radiated by lightning, Geophys. Res. Lett., 28, 143-146, 2001.

Thomas, R. J., Krehbiel, P. R., Rison, W., Hunyady, S. J., Winn, W. P., Hamlin, T., and Harlin, J.: Accuracy of the Lightning Mapping Array, J. Geophys. Res., 109, D14207, doi:10.1029/2004JD004549, 2004.

Thomas, W., Baier, F., Erbertseder, T., and Kästner, M.: Analysis of the Algerian severe weather event in November 2001 and its impact on ozone and nitrogen dioxide distributions, Tellus, 55B, 993-1006, 2003.

Thompson, A. M.: The oxidizing capacity of the Earth's atmosphere: Probable past and future changes, Science, 256, 1157 1165, 1992.

Thompson, A. M., Tao, W. K., Pickering, K. E., Scala, J. R., and Simpson, J.: Tropical deep convection and ozone formation, Bull. AMS, 78, 1043-1054, 1997.

Thompson, A. M., Sparling, L. C., Kondo, Y., Anderson, B. E., Gregory, G. L., and Sachse, G. W.: Perspectives on NO, NOy and fine aerosol sources and variability during SONEX, Geophys. Res. Lett., 26, 3073-3076, doi:10.1029/1999GL900581, 1999.

Thompson, A. M., Doddridge, B. G., Witte, J. C., Hudson, R. D., Luke, W. T., Johnson, J. E., Johnson, B. J., Oltmans, S. J., and Weller, R.: A tropical Atlantic paradox: shipboard and satellite views of a tropospheric ozone maximum and wave-one in January-February 1999, Geophys. Res. Lett., 27, 3317-3320, 2000a.

Thompson, A. M., Singh, H. B., and Schlager, H.: Introduction to special section: Subsonic Assessment Ozone and Nitrogen Oxide Experiment (SONEX) and Pollution from Aircraft Emissions in the North Atlantic Flight Corridor (POLINAT 2), J. Geophys. Res., 105, 3595-3603, 2000b.

Thompson, A. M.: Intercontinental transport of ozone from tropical biomass burning, in: Intercontinental Transport of Air Pollution, edited by: Stohl, A., pp. 225-253, Springer, Berlin, 2004.

Thornton, J. A., Wooldridge, P. J., and Cohen, R. C.: Atmospheric $\mathrm{NO}_{2}$ : In situ laser-induced fluorescence detection at parts per trillion mixing ratios, Anal. Chem., 72, 528-539, 2000.

Tie, X., Zhang, R., Brasseur, G., Emmons, L., and Lei, W.: Effects of lightning on reactive nitrogen and nitrogen reservoir species in the troposphere, J. Geophys. Res., 106, 3167-3178, doi:10.1029/2000JD900565, 2001.

Tie, X., Zhang, R., Brasseur, G., and Lei, W.: Global NOx production by lightning, J. Atmos. Chem., 43, 61-74, 2002.

Tiedtke, M.: A comprehensive mass flux scheme for cumulus parameterization in large-scale models, Mon. Wea. Rev., 117, 1779-1800, 1989.

Toracinta, E. R., Cecil, D. J., Zipser, E. J., and Nesbitt, S. W.: Radar, passive microwave, and lightning characteristics of precipitating systems in the tropics Mon. Wea. Rev., 130, 802-824, 2002. 
Torres, A. L., Buchan, H., and Tuck, A. F.: Tropospheric nitric oxide measurements over the Amazon Basin, J. Geophys. Res., 93, 1396-1406, 1988.

Tost, H., Jöckel, P., and Lelieveld, J.: Influence of different convection parameterisations in a GCM, Atmos. Chem. Phys., 6, 54755493, 2006,

http://www.atmos-chem-phys.net/6/5475/2006/.

Tost, H., Jöckel, P., and Lelieveld, J.: Lightning and convection parameterisations - uncertainties in global modelling, Atmos. Chem. Phys. Discuss., 7, 6767-6801, 2007,

http://www.atmos-chem-phys-discuss.net/7/6767/2007/.

Toumi, R., Haigh, J. D., and Law, K. S.: A tropospheric ozonelightning climate feedback, Geophys. Res. Lett., 23, 1037-1040, doi:10.1029/96GL00944, 1996.

Trebs, I., Lara, L. L., Zeri, L. M. M., Gatti, L. V., Artaxo, P., Dlugi, R., Slanina, J., Andreae, M. O., and Meixner, F. X.: Dry and wet deposition of inorganic nitrogen compounds to a tropical pasture site (Rondonia, Brazil), Atmos. Chem. Phys., 6, 447-469, 2006, http://www.atmos-chem-phys.net/6/447/2006/.

Tuck, A. F.: Production of nitrogen oxides by lightning discharges, Quart. J. Roy. Meteor. Soc., 102, 749-755, 1976.

Turman, B. N. and Edgar, B. C.: Global lightning distributions at dawn and dusk, J. Geophys. Res., 87, 1191-1206, 1982.

Uman, M. A.: The Lightning Discharge, 377 pp., Academic Press, Orlando, 1987.

Unger, N., Shindell, D. T., Koch, D. M., Amann, M., Cofala, J., and Streets, D. G.: Influences of man-made emissions and climate changes on tropospheric ozone, methane, and sulfate at 2030 from a broad range of possible futures, J. Geophys. Res., 111, D12313, doi:10.1029/2005JD006518, 2006.

Untch, A., Miller, M., Hortal, M., Buizza, R., and Janssen, P.: Towards a global meso-scale model: The high resolution system T799L91 and T399L62 EPS, ECMWF Newsletter, no. 108, 613, 2006.

Ushio, T., Heckman, S. J., Boccippio, D. J., Christian, H. J., and Kawasaki, Z.-I.: A survey of thunderstorm flash rates compared to cloud top height using TRMM satellite data, J. Geophys. Res., 106, 24 089-24 095, 2001.

van den Broeke, M. S., Schultz, D. M., Johns, R. H., Evans, J. S., and Hales, J. E.: Cloud-to-ground lightning production in strongly forced, low-instability convective lines associated with damaging wind, Wea. Forecasting, 20, 517-530, doi:10.1175/WAF876.1, 2005.

van $\operatorname{der}$ A, R. J., Peters, D. H. M. U., Eskes, H., Boersma, K. F., van Roozendael, M., De Smedt, I., and Kelder, H. M.: Detection of the trend and seasonal variation in tropospheric $\mathrm{NO}_{2}$ over China, J. Geophys. Res., 111, D12317, doi:10.1029/2005JD006594, 2006.

van Noije, T. P. C., Eskes, H. J., Dentener, F. J., et al.: Multimodel ensemble simulations of tropospheric $\mathrm{NO}_{2}$ compared with GOME retrievals for the year 2000, Atmos. Chem. Phys., 6, 2943-2979, 2006,

http://www.atmos-chem-phys.net/6/2943/2006/.

van Velthoven, P. F. J., Sausen, R., Johnson, C. E., et al.: The passive transport of $\mathrm{NO}_{\mathrm{x}}$ emissions from aircraft studied with a hierarchy of models, Atmos. Environ., 31, 1783-1799, 1997.

Velders, G. J. M., Granier, C., Portmann, R. W., Pfeilsticker, K., Wenig, M., Wagner, T., Platt, U., Richter, A., and Burrows, J. P.: Global tropospheric $\mathrm{NO}_{2}$ column distributions: Compar- ing three-dimensional model calculations with GOME measurements, J. Geophys. Res., 106, 12 643-12 660, 2001.

Viemeister, P. E.: Lightning and the origin of nitrates found in precipitation, J. Meteorol., 17, 681-683, 1960.

Volz-Thomas, A., Berg, M., Heil, T., Houben, N., Lerner, A., Petrick, W., Raak, D., and Pätz, H.-W.: Measurements of total odd nitrogen $\left(\mathrm{NO}_{\mathrm{y}}\right)$ aboard MOZAIC in-service aircraft: instrument design, operation and performance, Atmos. Chem. Phys., 5, 583595, 2005,

http://www.atmos-chem-phys.net/5/583/2005/.

von Glasow, R., Lawrence, M. G., Sander, R., and Crutzen, P. J.: Modeling the chemical effects of ship exhaust in the cloud-free marine boundary layer, Atmos. Chem. Phys., 3, 233-250, 2003, http://www.atmos-chem-phys.net/3/233/2003/.

von Kuhlmann, R., Lawrence, M. G., Crutzen, P. J., and Rasch, P. J.: A model for studies of tropospheric ozone and nonmethane hydrocarbons: Model evaluation of ozone-related species, J. Geophys. Res., 108, 4729, doi:10.1029/2002JD003348, 2003a.

von Kuhlmann, R., Lawrence, M. G., Crutzen, P. J., and Rasch, P. J.: A model for studies of tropospheric ozone and nonmethane hydrocarbons: Model description and ozone results, J. Geophys. Res., 108, 4294, doi:10.1029/2002JD002893, 2003b.

von Liebig, J.: Note sur la Nitrification, Ann. Chem. Phys., 35, 329-333, 1827.

Vonnegut, B.: Some facts and speculations concerning the origin and role of thunderstrom electricity, in: Severe Local Storms, Meteorol. Monogr., vol. 5, no. 27, edited by: Atlas, D., Booker, D. R., Byers, H., et al., pp. 224-241, Am. Meteor. Soc., Boston, 1963.

Wacker, R. S. and Orville, R. E.: Changes in measured lightning flash count and return stroke peak current after the U. S. National Lightning Detection Network upgrade Observation, J. Geophys. Res., 104, 2151-2157, 1999.

Wang, C. and Prinn, R. G.: On the roles of deep convective clouds in tropospheric chemistry, J. Geophys. Res., 105, 22 269-22 297, 2000.

Wang, Y., DeSilva, A. W., Goldenbaum, G. C., and Dickerson, R. R.: Nitric oxide production by simulated lightning: Dependence on current, energy, and pressure, J. Geophys. Res., 103, $19149-$ 19 159, 1998a.

Wang, Y., Jacob, D. J., and Logan, J. A.: Global simulation of tropospheric $\mathrm{O}_{3}-\mathrm{NO}_{\mathrm{X}}$-hydrocarbon chemistry -1 . Model formulation, J. Geophys. Res., 103, 10713-10725, 1998b.

Wang, Y., Liu, S. C., Anderson, B. E., Kondo, Y., Gregory, G. L., Sachse, G. W., Vay, S. A., Blake, D. R., Singh, H. B., and Thompson, A. M.: Evidence of convection as a major source of condensation nuclei in the northern midlatitude upper troposphere, Geophys. Res. Lett., 27, 369-372, doi:10.1029/1999GL010930, 2000.

Warneck, P.: Chemistry of the Natural Atmosphere, 757 pp., Academic Press, San Diego, 1988.

Wauben, W. M. F., van Velthoven, P. F. J., and Kelder, H.: A $3 \mathrm{D}$ chemistry transport model study of changes in atmospheric ozone due to aircraft $\mathrm{NO}_{\mathrm{x}}$ emissions, Atmos. Environ., 31, 18191836, 1997.

Weller, R., Lilischkis, R., Schrems, O., Neuber, R., and Wessel, S.: Vertical ozone distribution in the marine atmosphere over the central Atlantic Ocean $\left(56^{\circ} \mathrm{S}-50^{\circ} \mathrm{N}\right)$, J. Geophys. Res., 101, 1387-1400, 1996. 
Weller, R., Jones, A. E., Wille, A., Jacobi, H.-W., McIntyre, H. P., Sturges, W. T., Huke, M., and Wagenbach, D.: Seasonality of reactive nitrogen oxides $\left(\mathrm{NO}_{\mathrm{y}}\right)$ at Neumayer Station, Antarctica, J. Geophys. Res., 107, 4673, doi:10.1029/2002JD002495, 2002.

Wenig, M., Kühl, S., Beirle, S., Bucsela, E., Jähne, B., Platt, U., Gleason, J., and Wagner, T.: Retrieval and analysis of stratospheric $\mathrm{NO}_{2}$ from the Global Ozone Monitoring Experiment, J. Geophys. Res., 109, D04315, doi:10.1029/2003JD003652, 2004.

Wiens, K. C., Rutledge, S. A., and Tessendorf, S. A.: The 29 June 2000 supercell observed during STEPS. Part II: Lightning and charge structure, J. Atmos. Sci., 62, 4151-4177, 2005.

Wild, O. and Prather, M. J.: Excitation of the primary tropospheric chemical mode in a global three-dimensional model, J. Geophys. Res., 105, 24 647-24 660, 2000.

Wild, O., Sundet, J. K., Prather, M. J., Isaksen, I. S. A., Akimoto, H., Browell, E. V., and Oltmans, S. J.: Chemical transport model ozone simulations for spring 2001 over the western Pacific: Comparisons with TRACE-P lidar, ozonesondes, and Total Ozone Mapping Spectrometer columns, J. Geophys. Res., 108, 8826, doi:10.1029/2002JD003283, 2003.

Wild, O. and Prather, M. J.: Global tropospheric ozone modeling: Quantifying errors due to grid resolution, J. Geophys. Res., 111, D11305, doi:10.1029/2005JD006605, 2005.

Wild, O.: Modelling the global tropospheric ozone budget: exploring the variability in current models, Atmos. Chem. Phys., 7, 2643-2660, 2007, http://www.atmos-chem-phys.net/7/2643/2007/.

Williams, E. R.: Large scale charge separation in thunderclouds, J. Geophys. Res., 90, 6013-6025, 1985.

Williams, E. R.: The Schumann resonance: A global tropical thermometer, Science, 256, 1184-1187, 1992.

Williams, E. R., Rutledge, S. A., Geotis, S. G., Renno, N., Rasmussen, E., and Rickenbach, T.: A radar and electrical study of tropical "hot towers", J. Atmos. Sci., 49, 1385-1386, 1992.

Williams, E. R.: Global circuit response to seasonal variations in global surface air temperature, Mon. Wea. Rev., 122, 1917-1929, 1994.

Williams, E. R., Rothkin, K., Stevenson, D., and Boccippio, D.: Global lightning variations caused by changes in thunderstorm flash rate and by changes in the number of thunderstorms, J. Appl. Meteorol., 39, 2223-2230, 2000.

Williams, E. R.: The electrification of severe storms, in: Severe Convective Storms, Meteorological Monographs vol. 28, no. 50, edited by: Doswell III, C. A., Amer. Meteor. Soc., Boston, Mass., 2001.

Williams, E. R., Rosenfeld, D., Madden, N., et al.: Contrasting convective regimes over the Amazon: Implications for cloud electrification, J. Geophys. Res., 107, 8082, doi:10.1029/2001JD000380, 2002.

Williams, E. R. and Stanfill, S.: The physical origin of the landocean contrast in lightning activity, C. R. Physique, 3, 12771292, 2002.

Williams, E. R. and Sátori, G.: Lightning, thermodynamic and hydrological comparison of the two tropical continental chimneys, J. Atmos. Solar-Terr. Phys., 66, 1213-1231, 2004.

Williams, E. R.: Lightning and climate: A review, Atmos. Res., 76, 272-287, 2005.

Williams, E. R., Mushtak, V., Rosenfeld, D., Goodman, S., and Boccippio, D.: Thermodynamic conditions favorable to superla- tive thunderstorm updraft, mixed phase microphysics and lightning flash rate, Atmos. Res., 76, 288-306, 2005.

Winterrath, T., Kurosu, T. P., Richter, A., and Burrows, J. P.: Enhanced $\mathrm{O}_{3}$ and $\mathrm{NO}_{2}$ in thunderstorm clouds: convection or production?, Geophys. Res. Lett., 26, 1291-1294, 1999.

WMO: Scientific Assessment of Ozone Depletion: 1998, World Meteorological Organisation, Geneva, Switzerland, 1999.

Wolff, E. W.: Nitrate in polar ice, in: Ice Core Studies of Global Biogeochemical Cycles, edited by: Delmas, R. J., pp. 195-224, Springer-V., Heidelberg, 1995.

Wong, S., Wang, W.-C., Isaksen, I. S. A., Berntsen, T. K., and Sundet, J. K.: A global climate-chemistry model study of presentday tropospheric chemistry and radiative forcing from changes in tropospheric $\mathrm{O}_{3}$ since the preindustrial period, J. Geophys. Res., 109, D11309, doi:10.1029/2003JD003998, 2004.

Wu, S., Mickley, L. J., Jacob, D. J., Logan, J. A., Yantosca, R. M., and Rind, D.: Why are there large differences between models in global budgets of tropospheric ozone?, J. Geophys. Res., 112, D05302, doi:10.1029/2006JD007801, 2007.

Yienger, J. J. and Levy II, H.: Empricial model of global soilbiogenic $\mathrm{NO}_{\mathrm{x}}$ emissions, J. Geophys. Res., 100, 11 447-11464, 1995.

Yu, F. and Turco, R. P.: On the contribution of lightning to ultrafine aerosol formation, Geophys. Res. Lett., 28, 155-158, 2001.

Zahn, A., Brenninkmeijer, C. A. M., Crutzen, P. J., Parrish, D. D., Sueper, D., Heinrich, G., Güsten, H., Fischer, H., Hermann, M., and Heintzenberg, J.: Electrical discharge source for tropospheric "ozone-rich transients", J. Geophys. Res., 107, 4638, doi:10.1029/2002JD002345, 2002.

Zel'dovich, Y. B. and Raizer, Y. P.: Physics of Shock Waves and High Temperature Hydrodynamic Phenomena, 566-571 pp., Academic, San Diego, California, 1967.

Zhang, G. J. and McFarlane, N. A.: Sensitivity of climate simulations to the parameterization of cumulus convection in the Canadian Climate Centre general circulation model, Atmos.-Ocean, 33, 407-446, 1995.

Zhang, R., Sanger, N. T., Orville, R. E., Tie, X., Randel, W., and Williams, E. R.: Enhanced $\mathrm{NO}_{\mathrm{x}}$ by lightning in the upper troposphere and lower stratosphere inferred from the UARS global $\mathrm{NO}_{2}$ measurements, Geophys. Res. Lett., 27, 685-688, 2000.

Zhang, R., Tie, X., and Bond, D. W.: Impacts of anthropogenic and natural $\mathrm{NO}_{\mathrm{X}}$ sources over the U.S. on tropospheric chemistry, PNAS, 100, 1505-1509, 2003a.

Zhang, X., Helsdon Jr., J. H., and Farley, R. D.: Numerical modeling of lightning-produced $\mathrm{NO}_{\mathrm{x}}$ using an explicit lightning scheme: 1. Two-dimensional simulation as a 'proof of concept', J. Geophys. Res., 108, 4579, doi:10.1029/2002JD003224, 2003 b.

Zhang, X., Helsdon Jr., J. H., and Farley, R. D.: Numerical modeling of lightning-produced $\mathrm{NO}_{\mathrm{X}}$ using an explicit lightning scheme: 2 . Three-dimensional simulation and expanded chemistry, J. Geophys. Res., 108, 4580, doi:10.1029/2002JD003225, $2003 \mathrm{c}$.

Ziereis, H., Schlager, H., Schulte, P., van Velthoven, P. F. J., and Slemr, F.: Distributions of $\mathrm{NO}, \mathrm{NO}_{\mathrm{x}}$, and $\mathrm{NO}_{\mathrm{y}}$ in the upper troposphere and lower stratosphere between $28^{\circ}$ and $61^{\circ} \mathrm{N}$ during POLINAT 2, J. Geophys. Res., 105, 3653-3664, 2000.

Zimmermann, P. H.: Moguntia: A handy global tracer model, in: Air Pollution Modeling and its Applications VI, edited by: Dop, 
H. V., Plenum, New York, 1988.

Zipser, E. J.: Deep cumulonimbus cloud systems in the tropics with and without lightning, Mon. Wea. Rev., 122, 1837-1851, 1994.

Zipser, E. J. and Lutz, K. R.: The vertical profile of radar reflectivity of convective cells: A strong indicator of storm intensity and lightning probability?, Mon. Wea. Rev., 122, 1751-1759, 1994.
Zipser, E. J., Cecil, D. J., Liu, C., Nesbitt, S. W., and Yorty, D. P.: Where are the most intense thunderstorms on Earth?, Bull. AMS, 87, 1057-1071, doi:10.1175/BAMS-87-8-1057, 2006.

Zuo, Y. and Deng, Y.: Evidence for the production of hydrogen peroxide in rainwater by lightning during thunderstorms, Geochim. Cosmochim. Acta, 64, 3451-3455, 1999. 